$\therefore \because 20+80$

$\therefore$;

$\because \pi$

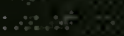

: 2000008
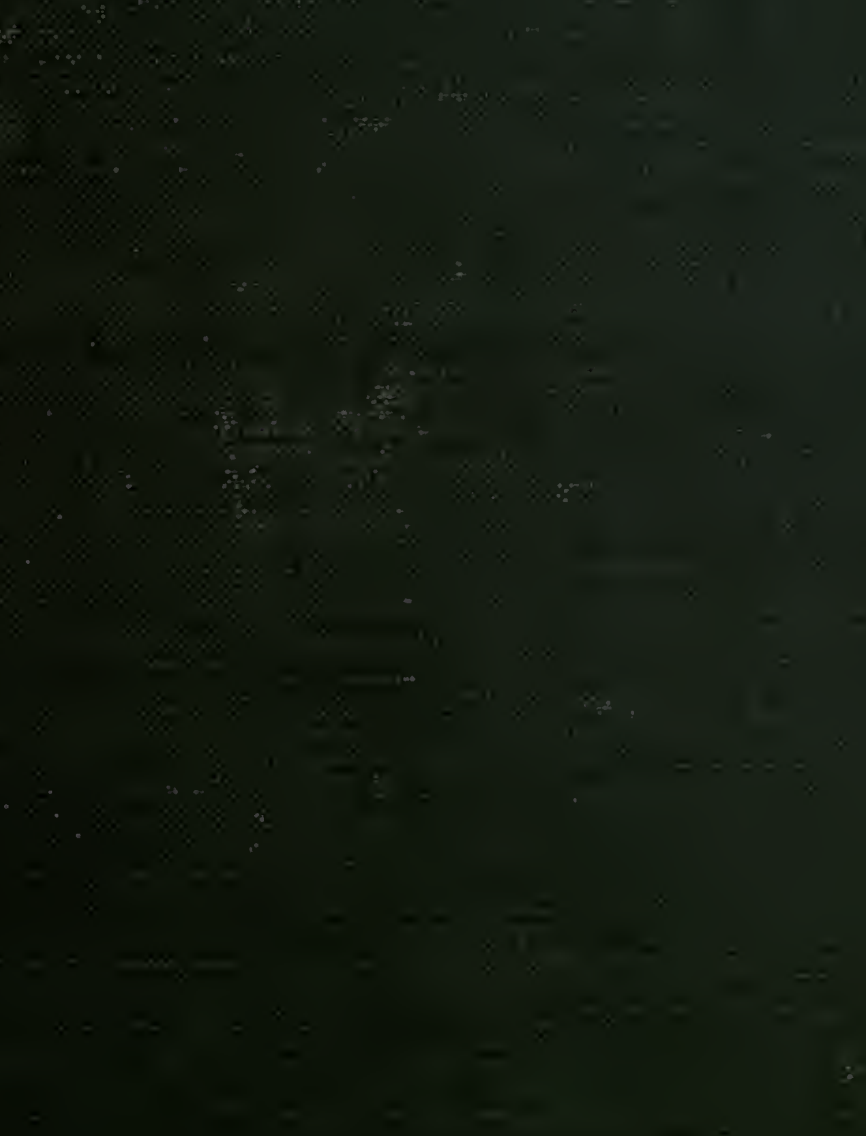


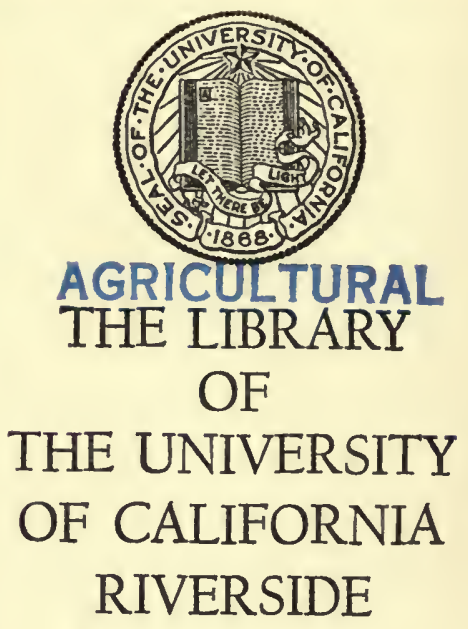




$$
\begin{gathered}
\frac{215}{d e 0} \\
\frac{13}{6}
\end{gathered}
$$




\section{Digitized by the Internet Archive in 2007 with funding from Microsoft Corporation .}


$10 \# 834969$

A SHORT HISTORY

OF

\title{
ENGLISH AGRICULTURE
}

\author{
W. H. R. CURTLER
}

OXFORD

AT THE CLARENDON PRESS

I909 


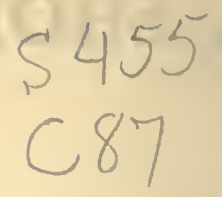

HENRY FROWDE, M.A. PUBLISHER TO THE UNIVERSITY OF OXFORD LONDON, EDINBURGH, NEIV YORK TORONTO AND MELBOURNE 


\section{PREFACE}

'A husBandMAN', said Markham, 'is the master of the earth, turning barrenness into fruitfulness, whereby all commonwealths are maintained and upheld. His labour giveth liberty to all vocations, arts, and trades to follow their several functions with peace and industrie. What can we say in this world is profitable where husbandry is wanting, it being the great nerve and sinew which holdeth together all the joints of a monarchy?' And he is confirmed by Young: 'Agriculture is, beyond all doubt, the foundation of every other art, business, and profession, and it has therefore been the ideal policy of every wise and prudent people to encourage it to the utmost.' Yet of this important industry, still the greatest in England, there is no history covering the whole period.

It is to remedy this defect that this book is offered, with much diffidence, and with many thanks to Mr. C. R. L. Fletcher of Magdalen College, Oxford, for his valuable assistance in revising the proof sheets, and to the Rev. A. H. Johnson of All Souls for some very useful information.

As the agriculture of the Middle Ages has often been ably described, I have devoted the greater part of this work to the agricultural history of the subsequent period, especially the seventeenth, eighteenth, and nineteenth centuries.

W. H. R. CURTLER.

May 22, 1909. 


\section{CONTENTS}

\section{CHAPTER I}

Communistic Farming.-Growth of the Manor. - Early Prices.-The Organization and Agriculture of the Manor

\section{CHAPTER II}

The Thirteenth Century.- The Manor at its Zenith, with Seeds of Decay already visible.-Walter of Henley .

\section{CHAPTER III}

The Fourteenth Century.-Decline of Agriculture.-The Black Death.-Statute of Labourers

\section{CHAPTER IV}

How the Classes connected with the Land lived in the Middle Ages

\section{CHAPTER V}

The Break-up of the Manor.-Spread of Leases.-The Peasants' Revolt.-Further Attempts to regulate Wages. A Harvest Home.-Beginning of the Corn Laws.-Some Surrey Manors

\section{CHAPTER VI}

1400-1540. The so-called 'Golden Age of the Labourer' in a Period of General Distress .

\section{CHAPTER VII}

Enclosure

\section{CHAPTER VIII}

Fitzherbert.-The Regulation of Hours and Wages 
I 540-I600. Progress at last.-Hop-growing.-Progress of Enclosure.-Harrison's Description . . . . 89

\section{CHAPTER $\mathrm{X}$}

I540-1600. Live Stock.-Flax.-Saffron.-The Potato.The Assessment of Wages . $\quad$. . . . . ${ }^{104}$

\section{CHAPTER XI}

1600-I 700. Clover and Turnips.-Great Rise in Prices.More Enclosure.-A Farming Calendar . .

\section{CHAPTER XII}

The Great Agricultural Writers of the Seventeenth Century.Fruit-growing.-A Seventeenth-century Orchard . .

\section{CHAPTER XIII}

The Evils of Common Fields. - Hops. - Implements. Manures.-Gregory King.-Corn Laws . . . .

\section{CHAPTER XIV}

1 700-65. General Characteristics of the Eighteenth Century.Crops.-Cattle.-Dairying.-Poultry. - Tull and the New Husbandry.-Bad Times.-Fruit-growing . . .

\section{CHAPTER XV}

I 700-65. Townshend.-Sheep-rot.-Cattle Plague.-Fruitgrowing $\cdot \cdot \cdot \cdot \cdot$
CHAPTER XVI

1765-93. Arthur Young.-Crops and their Cost.-The Labourers' Wages and Diet.-The Prosperity of Farmers.-The Country Squire.-Elkington.-Bakewell. -The Roads.-Coke of Holkham. 


\section{CONTENTS \\ CHAPTER XVII}

PAGE

1793-1815. The Great French War,-The Board of Agriculture.-High Prices, and Heavy Taxation.

\section{CHAPTER XVIII}

Enclosure.-The Small Owner

$25^{2}$

\section{CHAPTER XIX}

1816-37. Depression

\section{CHAPTER XX}

1837-75. Revival of Agriculture.-The Royal Agricultural Society.-Corn Law Repeal.-A Temporary Set-back.The Halcyon Days

\section{CHAPTER XXI}

1875-1908. Agricultural Distress again.-Foreign Competition.-Agricultural Holdings Act.-New Implements. -Agricultural Commissions. - The Situation in 1908 .

\section{CHAPTER XXII}

Imports and Exports.-Live Stock

$3^{23}$

\section{CHAPTER XXIII}

Modern Farm Live Stock.

\section{APPENDICES}

I. Average Prices from 1259 to I 700

II. Exports and Imports of Wheat and Flour from and into England, unimportant years omitted .

III. Average Prices per Imperial Quarter of British Corn in England and Wales, in each year from 177 I to 1907 inclusive .

IV. Miscellaneous Information 


\section{LANDMARKS IN ENGLISH AGRICULTURE}

1086. Domesday inquest, most cultivated land in tillage. Annual value of land about $2 d$. an acre.

1216-72. Henry III. Assize of Bread and Ale. 1272-1307. Edward I. General progress. Walter of Henley.

1307. Edward II. Decline.

1315. Great famine.

1337. Export of wool prohibited.

1348-9. Black Death. Heavy blow to manorial system. Many demesne lands let, and much land laid down to grass.

1351. Statute of Labourers.

1360. Export of corn forbidden.

1381. Villeins' revolt.

1393. Richard II allows export of corn under certain conditions.

1463. Import of wheat under $6 s$. $8 d$. prohibited.

End of fifteenth century. Increase of enclosure.

1523. Fitzherbert's Surveying and Husbandry.

1540. General rise in prices and rents begins.

1549. Kett's rebellion. The last attempt of the English peasant to obtain redress by force.

1586. Potatoes introduced.

1601. Poor Law Act of Elizabeth.

1645. Turnips and clover introduced as field crops.

1662. Statute of Parochial Settlement.

1664. Importation of cattle, sheep, and swine forbidden.

1688. Bounty of 5 . per quarter on export of wheat, and high duty on import.

1733. Tull publishes his Horse-hoeing Husbandry.

1739. Great sheep-rot.

1750. Exports of corn reached their maximum.

1760. Bakewell began experimenting.

I 760 (about). Industrial and agrarian revolution, and great increase of enclosure.

1764. Elkington's new drainage system.

1773. Wheat allowed to be imported at a nominal duty of $6 d$. a quarter when over $48 s$. 
1777. Bath and West of England Society established, the first in England.

1789. England definitely becomes a corn-importing country.

1793. Board of Agriculture established.

1795. Speenhamland Act.

About same date swedes first grown.

1815. Duty on wheat reached its maximum.

1815-35. Agricultural distress.

1825. Export of wool allowed.

1835. Smith of Deanston, the father of modern drainage.

1838. Foundation of Royal Agricultural Society.

1846. Repeal of the Corn Laws.

1855-75. Great agricultural prosperity.

1875. English agriculture feels the full effect of unrestricted competition, with disastrous results.

, First Agricultural Holdings Act.

1879-80. Excessive rainfall, sheep-rot, and general distress. 


\section{CHAPTER I}

COMMUNISTIC FARMING. - GROWTH OF THE MANOR.-EARLY PRICES. - THE ORGANIZATION AND AGRICULTURE OF THE MANOR

WHEN the early bands of English invaders came over to take Britain from its Celtic owners, it is almost certain that the soil was held by groups and not by individuals, and as this was the practice of the conquerors also they readily fell in with the system they found. ${ }^{1}$ These English, unlike their descendants of to day, were a race of countrymen and farmers and detested the towns, preferring the lands of the Britons to the towns of the Romans. Co-operation in agriculture was necessary because to each household were allotted separate strips of land, nearly equal in size, in each field set apart for tillage, and a share in the meadow and waste land. The strips of arable were unfenced and ploughed by common teams, to which each family would contribute.

Apparently, as the land was cleared and broken up it was dealt out acre by acre to each cultivator; and supposing each group consisted of ten families, the typical holding of 120 acres was assigned to each family in acre strips, and these strips were not all contiguous but mixed up with those of other families. The reason for this mixture of strips is obvious to any one who knows how land even in the same field varies in quality; it was to give each family its share of both good and bad land, for the householders were all equal and the principle on which the original distribution of the land depended was that of equalizing the shares of the different members of the community. ${ }^{2}$

1 Vinogradoff, Growth of the Manor, p. 18 ; Medley, Constitutional History, p. I5.

2 Vinogradoff, Villeinage in England, p. 257. 
In attributing ownership of lands to communities we must be careful not to confound communities with corporations. Maitland thinks the early land-owning communities blended the character of corporations and of co-owners, and co-ownership is ownership by individuals. ${ }^{1}$ The vills or villages founded on their arrival in Britain by our English forefathers resembled those they left at home, and even there the strips into which the arable fields were divided were owned in severalty by the householders of the village. There was co-operation in working the fields but no communistic division of the crops, and the individual's hold upon his strips developed rapidly into an inheritable and partible ownership. 'At the opening of Anglo-Saxon history absolute ownership of land in severalty was established and becoming the rule.' ${ }^{2}$

In the management of the meadow land communal features were much more clearly brought out; the arable was not reallotted, ${ }^{3}$ but the meadow was, annually; while the woods and pastures, the right of using which belonged to the householders of the village, were owned by the village 'community'. There may have been at the time of the English conquest Roman 'villas' with slaves and coloni cultivating the owners' demesnes, which passed bodily to the new masters; but the former theory seems true of the greater part of the country.

At first 'extensive' cultivation was practised; that is, every year a fresh arable field was broken up and the one cultivated last year abandoned, for a time at all events; but gradually 'intensive' culture superseded this, probably not till after the English had conquered the land, and the same field was cultivated year after year. ${ }^{4}$ After the various families or households had finished cutting the grass in their allotted portions of meadow, and the corn on their strips of tillage,

1 Maitland, Domesday Book and Beyond, pp. $34 \mathrm{I}$ et seq.

2 Stubbs, Constitutional History, $\$ 36$.

3 Vinogradoff, English Society in the Eleventh Century, p. 282, says, 'As a rule it was not subject to redivision.'

"Cunningham, Growth of English Industry and Commerce, i. 42. 
both grass and stubble became common land and were thrown open for the whole community to turn their stock upon.

The size of the strips of land in the arable fields varied, but was generally an acre, in most places a furlong (furrow long) or 220 yards in length, and 22 yards broad; or in other words, 40 rods of $5 \frac{1}{2}$ yards in length and 4 in breadth. There was, however, little uniformity in measurement before the Norman Conquest, the rod by which the furlongs and acres were measured varying in length from 12 to 24 feet, so that one acre might be four times as large as another.' The acre was, roughly speaking, the amount that a team could plough in a day, and seems to have been from early times the unit of measuring the area of land. ${ }^{2}$ Of necessity the real acre and the ideal acre were also different, for the reason that the former had to contend with the inequalities of the earth's surface and varied much when no scientific measurement was possible. As late as 1820 the acre was of many different sizes in England. In Bedfordshire it was 2 roods, in Dorset 134 perches instead of 160 , in Lincolnshire 5 roods, in Staffordshire $2 \frac{1}{4}$ acres. Today the Cheshire acre is 10,240 square yards. As, however; an acre was and is a day's ploughing for a team, we may assume that the most usual acre was the same area then as now. There were also half-acre strips, but whatever the size the strips were divided one from another by narrow grass paths generally called 'balks', and at the end of a group of these strips was the 'headland' where the plough turned, the name being common to-day. Many of these common fields remained until well on in the nineteenth century; in 1815 half the county of Huntingdon was in this condition, and a few still exist. ${ }^{3}$ Cultivating the same field year after year naturally exhausted the soil, so that the two-field system came in, under

1 Maitland, op. cit. p. 368.

3 Anonymous Treatise on Husbandry, Royal Historical Society, pp. xli. and 68. About 1230, Smyth, in his Lives of the Berkeleys, i. II3, says, 'At this time lay all lands in common fields, in one acre or ridge, one man's intermixt with another.'

8 See p. 22. 
which one was cultivated and the other left fallow; and this was followed by the thiree-field system, by which two were cropped in any one year and one lay fallow, the last-named becoming general as it yielded better results, though the former continued, especially in the North. Under the threefield plan the husbandman early in the autumn would plough the field that had been lying fallow during summer, and sow wheat or rye; in the spring he broke up the stubble of the field on which the last wheat crop had been grown and sowed barley or oats; in June he ploughed up the stubble of the last spring crop and fallowed the field. ${ }^{1}$ As soon as the crops began to grow in the arable fields and the grass in the meadows to spring, they were carefully fenced to prevent trespass of man and beast; and, as soon as the crops came off, the fields becane common for all the village to turn their stock upon, the arable fields being usually common from Lammas (August I) to Candlemas (February 2) and the meadows from July 6, old Midsummer Day, to Candlemas ${ }^{2}$; but as in this climate the season both of hay and corn harvest varies considerably, these dates cannot have been fixed.

The stock, therefore, besides the common pasture, had after harvest the grazing of the common arable fields and of the meadows. The common pasture was early 'stinted' or limited, the usual custom being that the villager could turn out as many stock as he could keep on his holding. The trouble of pulling up and taking down these fences every year must have been enormous, and we find legislation on this important matter at an early date. About 700 the laws of

1 Cunningham, Growth of English Industry and Commerce, i. 74. Maitland thinks the two-field system was as common as the three-field, both in early and mediaeval times. Domesday Book and Beyond, p. 366.

2 Nasse, Agricultural Community of the Middle Ages, p. 5. To-day harvest generally commences about August $I$, so that this, like the growth of grapes in mediaeval times, seems to show our climate has grown colder. 
Ine, King of Wessex, provided that if 'churls have a common. meadow or other partible land to fence, and some have fenced their part and some have not, and cattle stray in and eat up their common corn or grass; let those go who own the gap and compensate to the others who have fenced their. part the damage which then may be done, and let them demand such justice on the cattle as may be right. But if there be a beast which breaks hedges and goes in everywhere, and he who owns it will not or cannot restrain it, let him who finds it in his field take it and slay it, and let the owner take its skin and flesh and forfeit the rest...

England was not given over to one particular type of settlement, although villages were more common than ham-: lets in the greater part of the country. ${ }^{1}$ The vill or village answers to the modern civil parish, and the term may be applied to both the true or 'nucleated' village of clustered houses and the village of scattered hamlets, each of a few houses, existing chiefly on the Celtic fringe. The population of some of the villages at the time of the Norman Conquest was numerous, I00 households or 500 people; but the average townships contained from 10 to 20 households. ${ }^{2}$ There was also the single farm, such as that at Eardisley in Herefordshire, described in Domesday, lying in the middle of a forest, perhaps, as in other similar cases, a pioneer settlement of some one more adventurous than his fellows. ${ }^{3}$

Such was the early village community in England, a community of free landholders. But a change began early to come over it.4. The king would grant to a church all the rights he had in the village, reserving only the trinoda necessitas, these rights including the feorm or farm, or provender rent which the king derived from the land-of cattle,

1 Vinogradoff, English Society in the Eleventh Century, p. 264.

2. Maitland, op. cit. p. 17.

3 Vinogradoff, English Society in the Eleventh Century, p. 265.

4 Maitland, op. cit. pp. 318 et seq. 
sheep, swine, ale, honey, \&c.-which he collected by visiting his villages, thus literally eating his rents. The churchmen did not continue these visits, they remained in their monasteries, and had the feorm brought them regularly; they had an overseer in the village to see to this, and so they tightened their hold on the village. Then the smaller people, the peasants, make gifts to the Church. They give their land, but they also want to keep it, for it is their livelihood; so they surrender the land and take it back as a lifelong loan. Probably on the death of the donor his heirs are suffered to hold the land. Then labour services are substituted for the old provender rents, and thus the Church acquires a demesne, and thus the foundations of the manorial system, still to be traced all over the country, were laid. Thegns, the predecessors of the Norman barons, become the recipients of grants from the churches and from kings, and householders 'commend' themselves and their land to them also, so that they acquired demesnes. This 'commendation ' was furthered by the fact that during the long-drawn out conquest of Britain the old kindred groups of the English lost their corporate sense, and the central power being too weak to protect the ordinary householder, who could not stand alone, he had to seek the protection of an ecclesiastical corporation or of some thegn, first for himself and then for his land. The jurisdictional rights of the king also passed to the lord, whether church or thegn; then came the danegeld, the tax for buying off the Danes that subsequently became a fixed land tax, which was collected from the lord, as the peasants were too poor for the State to deal with them; the lord paid the geld for their land, consequently their land was his. In this way the free ceorl of Anglo-Saxon times gradually becomes the 'villanus' of Domesday. Landlordship was well established in the two centuries before the Conquest, and the land of England more or less 'carved into territorial lordships'.'

${ }^{1}$ Vinogradoff, English Society in the Eleventh Century, p. 345. 
Therefore when the Normans brought their wonderful genius for organization to this country they found the material conditions of manorial life in full growth; it was their task to develop its legal and economic side. ${ }^{1}$

As the manorial system thus superimposed upon the village community was the basis of English rural economy for centuries, there need be no apology for describing it at some length.

The term ' manor', which came in with the Conquest, ${ }^{2}$ has a technical meaning in Domesday, referring to the system of taxation, and did not always coincide with the vill or village, though it commonly did so, except in the eastern portion of England. The village was the agrarian unit, the manor the fiscal unit; so that where the manor comprised more than one village, as was frequently the case, there would be more than one village organization for working the common fields. ${ }^{3}$

The manor then was the 'constitutive cell' of English mediaeval society. ${ }^{4}$ The structure is always the same; under the headship of the lord we find two layers of population, the villeins and the freeholders; and the territory is divided into demesne land and tributary land of two classes, viz. that of the villeins and that of the freeholders. The cultivation of the demesne (which usually means the land directly occupied and cultivated by the lord, though legally it has a wider meaning and includes the villein tenements), depends to a certain extent on the work supplied by the tenants of the tributary land. Rents are collected, labour superintended, administrative business transacted by a set of manorial officers.

We may divide the tillers of the soil at the time of Domesday into five great classes, ${ }^{5}$ in order of dignity and freedom:

r. Liberi homines, or freemen.

2. Socmen.

1 Vinogradoff, English Society in the Eleventh Century, p. 339.

2 Maitland, Domesday Book, p. $110 .{ }^{8}$ Vinogradoff, op. cit. p. 395.

4 Vinogradoff, Villeinage in England, pp. 223 et seq.

${ }_{5}^{5}$ Maitland, op. cit. p. 23. 
3. Villeins.

4. Bordarii, cotarii, buri or coliberti.

5. Slaves.

The two first of these classes were to be found in large numbers in Norfolk, Suffolk, Lincolnshire, Nottinghamshire, Leicestershire, and Northamptonshire. It is not easy to draw the line between them, but the chief distinction lay in the latter being more burdened with service and customary dues and more especially subject to the jurisdictional authority of the lord. ${ }^{1}$ They were both free, but both rendered services to the lord for their land. Both the freemen and the slaves by 1086 were rapidly decreasing in number.

The most numerous class ${ }^{2}$ on the manors was the third, that of the villeins or non-free tenants, who held their land by payment of services to the lord. The position of the villein under the feudal system is most complicated. He both was and was not a freeman. He was absolutely at the disposal of the lord, who could sell him with his tenement, and he could not leave his land without his lord's permission. $\mathrm{He}$ laboured under many disabilities, such as the merchet or fine for marrying his daughter, and fines for selling horse or ox. On the other hand, he was free against every one but his lord, and even against the lord was protected from the forfeiture of his 'wainage' or instruments of labour and from injury to life and limb.

His usual holding was a virgate of 30 acres of arable, though the virgate differed in size even in the same manors; but in addition to this he would have his meadow land and his share in the common pasture and wood, altogether about roo acres of land. For this he rendered the following services to the lord of the manor:

I. Week work, or labour on the lord's demesne for two or

1 Vinogradoff, op. cit. p. 433.

2 In Domesday they number 108,500. Maitland, Domesday Book, p. 38.

${ }^{3}$ Maitland, op. cit. p. 43 . 
three days a week during most of the year, and four or five days in summer. It was not always the villein himself, however, who rendered these services, he might send his son or even a hired labourer; and it was the holding and not the holder that was considered primarily responsible for the rendering of services. ${ }^{1}$

2. Precarii or boon days: that is, work generally during harvest, at the lord's request, sometimes instead of week work, sometimes in addition.

3. Gafol or tribute: fixed payments in money or kind, and such services as 'fold soke', which forced the tenants' sheep to lie on the lord's land for the sake of the manure; and suit of mill, by which the tenant was bound to grind his corn in the lord's mill.

With regard to the 'boon days' in harvest, it should be remembered that harvest time in the Middle Ages was a most important event. Agriculture was the great industry, and when the corn was ripe the whole village turned out to gather it, the only exceptions being the housewives and sometimes the marriageable daughters. Even the larger towns suspended work that the townsmen might assist in the harvest, and our long vacation was probably intended originally to cover the whole work of gathering in the corn and hay. On the occasion of the 'boon-day' work, the lord usually found food for the labourers which, the Inquisition of Ardley ${ }^{2}$ tells us, might be of the following description: for two men, porridge of beans and peas and two loaves, one white, the other of ' mixtil' bread ; that is, wheat, barley, and rye mixed together, with a piece of meat, and beer for their first meal. Then in the evening they had a small loaf of mixtil bread and two 'lescas' of cheese. While harvest work was going on the better-off tenants, usually the free ones, were sometimes employed to ride about, rod in hand, superintending the others.

1 Vinogradoff, English Society in the Eleventh Century, p. 300.

2 Domestay of $S$. Paul, p. lxviii. 
The services of the villeins were often very comprehensive, and even included such tasks as preparing the lord's bath; but on some manors their services were very light. ${ }^{1}$

When the third of the above obligations, the gafol or tribute, was paid in kind it was most commonly made in corn; and next came honey, one of the most important articles of the Middle Ages, as it was used for both lighting and sweetening purposes. Ale was also common, and poultry and eggs, and sometimes the material for implements.

These obligations were imposed for the most part on free and unfree tenants alike, though those of the free were much lighter than those of the unfree; the chief difference between the two, as far as tenure of the land went, lay in the fact that the former could exercise proprietary rights over his holding more or less freely, the latter had none. ${ }^{2}$

It seems very curious to the modern mind that the villein, a man who farmed about I00 acres of land, should have been in such a servile condition.

The amount of work due from each villein came to be fixed by the extent or survey of the manor, but the quality of it was not ${ }^{3}$; that is, each one knew how many days he had to work, but not whether he was to plough, sow, or harrow, \&c. It is surprising to find, that on the festival days of the Church, which were very numerous and observed as holy days, the lord lost by no work being done, and the same was the case in wet weather.

One of the most important duties of the tenant was the 'averagium', or duty of carrying for the lord, especially necessary when his manors were often a long way apart. He would often have to carry corn to the nearest town for sale, the products of one manor to another, also to haul manure on to

1 Maitland, Domesday Book, p. 56.

2 Cunningham, Grozuth of English Industry and Commerce, i. 166. In some manors free tenants could sell their lands without the lord's licence, in others not.

$\checkmark$ Vinogradoff, Villeinage in England, p. 279. 
the demesne. If he owned neither horse nor ox, he would sometimes have to use his own back. ${ }^{1}$

The holding of the villein did not admit of partition by sale or descent, it remained undivided and entire. When the holder died all the land went to one of the sons if there were several, often to the youngest. The others sought work on the manor as craftsmen or labourers, or remained on the family plot. The holding therefore might contain more than one family, but to the lord remained one and undivided. ${ }^{2}$

In the fourth class came the bordarii, the cotarii, and the coliberti or buri ; or, as we should say, the crofters, the cottagers, and the boors.

The bordarii numbered 82,600 in Domesday, and were subject to the same kind of services as the villeins, but the amount of the service was considerably less. ${ }^{3}$ Their usual holding was 5 acres, and they are very often found on the demesne of the manor, evidently in this case labourers on the demesne, settled in cottages and provided with a bit of land of their own. The name failed to take root in this country, and the bordarii seem to become villeins or cottiers. ${ }^{4}$

The cotarii, cottiers or cottagers, were 6,800 in number, with small pieces of land sometimes reaching 5 acres. ${ }^{5}$ Distinctly inferior to the villeins, bordarii, and cottars, but distinctly superior to the slaves, were the buri or coliberti who, with the bordars and cottars, would form a reserve of labour to supplement the ordinary working days at times when work was pressing, as in hay time and harvest. At the bottom of the social ladder in Domesday came the slaves, some 25,000 in number, who in the main had no legal rights, a class which

1 Vinogradoff, Villeinage in England, p. 285.

2 Ibid. p. 246; and English Society in the Eleventh Century, p. 448. At the end of the eighteenth century, in default of sons, lands in some manors in Shropshire descended to the youngest daughter.-Bishton, General View of the Agriculture of Shropshire, p. 178.

${ }^{3}$ Vinogradoff, English Society in the Eleventh Century, p. 456.

4 Maitland, Domesiay Book, p. 40.

5 Ibid. 
hàd apparently already diminished and was diminishing in numbers, so that for the cultivation of the demesne the lord was coming to rely more on the labour of his tenants, and consequently the labour services of the villeins were being augmented.' The agricultural labourer as we understand him, a landless man working solely for wages in cash, was almost unknown.

All the arrangements of the manor aimed at supplying labour for the cultivation of the lord's demesne, and he had three chief officers to superintend it:

I. The seneschal, who answers to our modern steward or land agent, and where there were several manors supervised all of them. He attended to the legal business and held the manor courts. It was his duty to be acquainted with every particular of the manor, its cultivation, extent, number of teams, condition of the stock, \&c. He was also the legal adviser of his lord; in fact, very much like his modern successor.

2. The bailiff for each manor, who collected rents, went to market to buy and sell, surveyed the timber, superintended the ploughing, mowing, reaping, \&c., that were due as services from the tenants on the lord's demesne; and according to Fleta he was to prevent their ' casting off before the work was done', and to measure it when done. ${ }^{2}$ And considering that those he superintended were not paid for their work, but rendering more or less unwelcome services, his task could not have been easy.

3. The praepositus or reeve, an office obligatory on every holder of a certain small quantity of land; a sort of foreman nominated from among the villeins, and to a certain extent representing their interests. His duties were supplementary to those of the bailiff: he looked after all the live and dead stock of the manor, saw to the manuring of the land, kept a tally of the day's work, had charge of the granary, and delivered there- 
from corn to be baked and malt to be brewed. ${ }^{1}$ Besides these three officers, on a large estate there would be a messor who took charge of the harvest, and many lesser officers, such as those of the akermanni, or leaders of the unwieldy plough teams; oxherds, shepherds, and swineherds to tend cattle, sheep, and pigs when they were turned on the common fields or wandered in the waste; also wardens of the woods and fences, often paid by a share in the profits connected with their charge; for instance, the swineherd of Glastonbury Abbey received a sucking-pig a year, the interior parts of the best pig, and the tails of all the others slaughtered." On the great estates these offices tended to become hereditary, and many families did treat them as hereditary property, and were a great nuisance in consequence to their lords. At Glastonbury we find the chief shepherd so important a person that, he was party to an agreement concerning a considerable quantity of land. ${ }^{3}$ There were also on some manors 'cadaveratores', whose duty was to look into and report on the losses of cattle and sheep from murrain, a melancholy tale of the unhealthy conditions of agriculture.

The supervision of the tenants was often incessant and minute. According to the Court Rolls of the Manor of Manydown in Hampshire, tenants were brought to book for all kinds of transgressions. The fines are so numerous that it almost appears that every person on the estate was amerced from time to time. In 1365 seven tenants were convicted of having pigs in their lord's crops, one let his horse run in the growing corn, two had cattle among the peas, four had cattle on the lord's pasture, three had made default in rent or service, four were convicted of assault, nine broke the assize of beer,

1 Domesday of S. Paul, xxxv. Fleta, 'an anonymous work drawn up in the thirteenth century to assist landowners in managing their estates,' says, the reeve 'shall rise early, and have the ploughs yoked, and then walk in the fields to see that all is right and note if the men be idle, or if they knock off work before the day's task is fully done.'

2 Vinogradoff, Villeinage in England, p. $32 \mathrm{I}$.

3 Ibid. p. 324 . 
two had failed to repair their houses or buildings. In all thirty-four were in trouble out of a population of some sixty families. The account is eloquent of the irritating restrictions of the manor, and of the inconveniences of common farming. ${ }^{1}$

It is impossible to compare the receipts of the lord of the manor at this period with modern rents, or the position of the villein with the agricultural labourer; it may be said that the lord received a labour rent for the villein's holding, or that the villein received his holding as wages for the services done for the lord, ${ }^{2}$ and part of the return due to the lord was for the use of the oxen with which he had stocked the villein's holding.

Though in 1066 there were many free villages, yet by the time of Domesday they were fast disappearing and there were manors everywhere, usually coinciding with the village, which we may picture to ourselves as self-sufficing estates, often isolated by stretches of dense woodland and moor from one another, and making each veritably a little world in itself. At the same time it is evident from the extent of arable land described in Domesday that many manors were not greatly isolated, and pasture ground was often common to two or more villages. ${ }^{3}$

If we picture to ourselves the typical manor, we shall see a large part of the lord's demesne forming a compact area within which stood his house; this being in addition to the lord's strips in the open fields intermixed with those of his tenants. The mansion house was usually a very simple affair, built of wood and consisting chiefly of a hall; which even as late as the seventeenth century in some cases served as kitchen, dining room, parlour, and sleeping room

1 Manor of Manydown, Hampshire Record Society, p. 17. Breaking the assize of beer meant selling it without a licence, or of bad quality. The village pound was the consequence of the perpetual straying of animals, and later on the vicar sometimes kept it. See ibid. p. I04.

- 2 Cunningham, Growth of English Industry and Commerce, i. 106.

3 Vinogradoff, Villeinage in England, p. 264. 
for the men; and one or two other rooms. ${ }^{1}$ It is probable that in early times the thegns possessed in most cases only one manor apiece, ${ }^{2}$ so that the manor house was then nearly always inhabited by the lord, but after the Conquest, when manors were bestowed by scores and even hundreds by William on his successful soldiers, many of them can only have acted as the temporary lodging of the lord when he came to collect his rent, or as the house of the bailiff. According to the Gerefa, written about 1000-and there was very little alteration for a long time afterwards-the mansion was adjacent to a court or yard which the quadrangular homestead surrounded with its barns, horse and cattle stalls, sheep pens and fowlhouse. Within this court were ovens, kilns, salthouse, and malt-house, and perhaps the hayricks and wood piles. Outside and surrounding the homestead were the enclosed arable and grass fields of the portion of the demesne which may be called the home farm, a kitchen garden, and probably a vineyard, then common in England. The garden of the manor house would not have a large variety of vegetables; some onions, leeks, mustard, peas, perhaps cabbage; and apples, pears, cherries, probably damsons, plums, ${ }^{3}$ strawberries, peaches, quinces, and mulberries. Not far off was the village or town of the tenants, the houses all clustering close together, each house standing in a toft or yard with some buildings, and built of wood, turf, clay, or wattles, with only one room which the tenant shared with his live stock, as in parts of Ireland to-day. Indeed, in some parts of Yorkshire at the beginning of the nineteenth century this primitive simplicity still prevailed, live stock were still kept in the house, the floors were of clay, and the

1 Andrews, Old English Manor, p. II I.

2 Domesday of S. Paul, p. xxxvii.

3 Thorold Rogers, Agriculture and Prices, i. 17 ; Cunningham, Industry and Commerce, i. 55 ; Neckham, De Natura Rerum, Rolls Series, ch. clxvi. Rogers says there were no plums, but Neckham mentions them. See also Denton, England in the Fifteenth Century, p. 64. Matthew Paris says the severe winter of 1257 destroyed cherries, plums, and figs. Chron. Maj., Rolls Series, v. 660. 
family slept in boxes round the solitary room. Examples of farm-houses clustered together at some distance from their respective holdings still survive, though generally built of stone. Next the village, though not always, for they were sometimes at a distance by the banks of a stream, were the meadows, and right round stretched the three open arable fields, beyond which was the common pasture and wood, ${ }^{1}$ and, encircling all, heath, forest, and swamp, often cutting off the manor from the rest of the world.

The basis of the whole scheme of measurement in Domesday was the hide, usually of 120 acres, the amount of land that could be ploughed by a team of 8 oxen in a year; a quarter of this was the virgate, an eighth the bovate, which would therefore supply one ox to the common team. These teams, however, varied; on the manors of S. Paul's Cathedral in 1222 they were sometimes composed of horses and oxen, or of 6 horses only, sometimes ro oxen. ${ }^{2}$

The farming year began at Michaelmas when, in addition to the sowing of wheat and rye, the cattle were carefully stalled and fed only on hay and straw, for roots were in the distant future, and the corn was threshed with the flail and winnowed by hand. In the spring, after the ploughing of the second arable field, the vineyard, where there was one, was set out, and the open ditches, apparently the only drainage then known, cleansed.

1 Woods were used as much for pasture as for cutting timber and underwood. Not only did the pigs feed there on the mast of oak, beech, and chestnut, but goats and horned cattle grazed on the grassy portions.

${ }^{2}$ The illustrations of contemporary MSS. usually show teams in the plough of 2 or 4 oxen, and 4 was probably the team generally used, according to Vinogradoff, $o p$. cit. p. 253. It must, of course, have varied according to the soil. Birch, in his Domesday, p. 219 , says he has never found a team of 8 in contemporary illustrations. To-day oxen can be still seen ploughing in teams of two only. However, about a hundred years ago, when oxen were in common use, we find teams of 8 , as in Shropshire, for a single-furrow plough, 'so as to work them easily.' Six hours a day was the usual day's work, and when more was required one team was worked in the morning, another in the afternoon.-Victoria County History: Shropshire, Agriculture. Walter of Henley says the team stopped work at three. 
In May it was time to set up the temporary fences round the meadows and arable fields, and to begin fallowing the third field.

A valuable document, describing the duties of a reeve, gives many interesting details of eleventh-century farming ${ }^{1}$ :-

'In May, June, and July one may harrow, carry out manure, set up sheep hurdles, shear sheep, do repairs, hedge, cut wood, weed, and make folds. In harvest one may reap ; in August, September, and in October one may mow, set woad with a dibble, gather home many crops, thatch them and cover them over, cleanse the folds, prepare cattle sheds and shelters ere too severe a winter come to the farm, and also diligently prepare the soil. In winter one should plough and in severe frosts cleave timber, make an orchard, and do many affairs indoors, thresh, cleave wood, put the cattle in stalls and the swine in pigstyes, and provide a hen roost. In spring one should plough and graft, sow beans, set a vineyard, make ditches, hew wood for a wild deer fence; and soon after that, if the weather permit, set madder, sow flax seed and woad seed, plant a garden and do many things which I cannot fully enumerate that a good steward ought to provide.'

The methods of cultivation were simple. The plough, if we may judge by contemporary illustrations, had in the eleventh century a large wheel and very short handles. ${ }^{2}$ In the twelfth century Neckham describes its parts : a beam, handles, tongue, mouldboard, coulter, and share. ${ }^{3}$ Breaking up the clods was done by the mattock or beetle, and harrowing was done by hand with what looks like a large rake; the scythes of the haymakers and the sickles of the reapers were very like those that still linger on in some districts to-day.

Here is a list of tools and implements for the homestead: an axe, adze, bill, awl, plane, saw, spokeshave, tie hook, auger, mattock, lever, share, coulter, goad-iron, scythe,

1 Cunningham, Growth of English Industry and Commerce, i. 570.

2 See the excellent reproductions of the Calendar of the Cott. MSS. in Green's Short History of the English People, illustrated edition, i. 155.

${ }^{3}$ De Natura Rerum, Rolls Series, p. 280.

CURTLER 
sickle, weed-hook, spade, shovel, woad dibble, barrow, besom, beetle, rake, fork, ladder, horse comb, shears, fire tongs, weighing scales, and a long list of spinning implements necessary when farmers made their own clothes. The author wisely remarks that one ought to have coverings for wains, plough gear, harrowing tackle, \&c.; and adds another list of instruments and utensils : a caldron, kettle, ladle, pan, crock, firedog, dishes, bowls with handles, tubs, buckets, a churn, cheese vat, baskets, crates, bushels, sieves, seed basket, wire sieve, hair sieve, winnowing fans, troughs, ashwood pails, hives, honey bins, beer barrels, bathing tub, dishes, cups, strainers, candlesticks, salt cellar, spoon case, pepper horn, footstools, chairs, basins, lamp, lantern, leathern bottles, comb, iron bin, fodder rack, meal ark or box, oil flask, oven rake, dung shovel; altogether a very complete list, the compiler of which ends by saying that the reeve ought to neglect nothing that should prove useful, not even a mousetrap, nor even, what is less, a peg for a hasp.

Manors in 1086 were of all sizes, from one virgate to enormous organizations like Taunton or Leominster, containing villages by the score and hundreds of dependent holdings. ${ }^{\text {? }}$ The ordinary size, however, of the Domesday manor was from four to ten hides of 120 acres each, or say from 500 to $I, 200$ acres, ${ }^{2}$ and the Manor of Segenehou in Bedfordshire may be regarded as typical. Held by Walter brother of Seiher it had as much land as ten ploughs could work, four plough lands belonging to the demesne and six to the villeins, of whom there were twenty-four, with four bordarii and three serfs; thus the villeins had 30 acres each, the normal holding. The manorial system was in fact a combination of large farming by the lords, and small farming by the tenants. Nor must we

1 Vinogradoff, English Society in the Eleventh Century, p. 307.

2 Ibid. p. 312. Perhaps one of the most interesting features of the smaller manors is that they were constantly being swallowed up by the larger. 
compare it to an ordinary estate; for it was a dominion within which the lord had authority over subjects of various ranks; he was not only a proprietor but a prince with courts of his own, the arbiter of his tenants' rights as well as owner of the land.

One of the most striking features of the Domesday survey is the large quantity of arable land and the small quantity of meadow, which usually was the only land whence they obtained their hay, for the common pasture cannot often have been mown. ${ }^{1}$ Indeed, it is difficult to understand how they fed their stock in hard winters.

According to the returns, in many counties more acres were ploughed in 1086 than to-day; in some twice as much. In Somerset in 1086 there were 577,000 acres of arable; in $1907,178,967$. In Gloucestershire, in $1086,589,000$ acres; in $1907,238,45^{6}{ }^{2}$ These are extreme instances; but the preponderance of arable is startling, even if we allow for the recent conversion of arable to pasture on account of the low price of corn. Between the eleventh century and the sixteenth, the laying down of land to grass must have proceeded on a gigantic scale, for Harrison tells us that in his day England was mainly a grazing country. No wonder Harrison's contemporaries complained of the decay of tillage.

Mediaeval prices and statistics are, it is well known, to be taken with great caution; but we may assume that the normal annual value of land under cultivation in 1086 was about $2 d$. an acre. ${ }^{3}$ Land indeed, apart from the stock upon it, was worth very little: in the tenth and eleventh centuries it appears that the hide, normally of 120 acres, was only worth $£ 5$ to buy, apparently with the stock upon it. In the time of Athelstan a horse was worth $120 d$., an ox $30 d$., a cow $20 d$., a

${ }^{1}$ As some of the common pasture was held in severalty, this may perhaps have been mown in scarce years. Walter of Henley mentions mowing the waste, see below, p. 34 .

2 Maitland, Domesday Book, 436; Board of Agriculture Returns, 1907.

3 Vinogradoff, English Society in the Eleventh Century, p. 310; Birch; Domesday, p. 183. 
sheep $5 d$., a hog $8 d$., a slave $£ I$-so that a slave was worth 8 oxen $^{1}$; and these prices do not seem to have advanced by the Domesday period.

According to the Pipe Roll of II56, wheat was Is. $6 d$. a quarter; but prices then depended entirely on seasons, and we do not know whether that was good or bad. However, many years later, in 1243 , it was only 25 . a quarter at Hawsted. ${ }^{2}$ In dear years, nearly always the result of wet seasons, it went up enormously; in 1024 the English Chronicle tells us the acre seed of wheat, that is about 2 bushels, sold for $6 s$., 3 bushels of barley for $6 s$., and 4 bushels of oats for $4 s^{3}$ In IIgo Holinshed says that, owing to a great 'dearth, the quarter of wheat was I $8 s .8 d$. The average price, however, in the twelfth century was probably about $4 s$. a quarter.

In II94 Roger of Hoveden ${ }^{4}$ says an ox, a cow, and a plough horse were the same price, 45 .; a sheep with fine wool Iod., with coarse wool $6 d$. ; a sow I $2 d$., a boar I $2 d$.

Sometimes prices were kept down by imports; 12.58 was a bad and dear year, 'most part of the corn rotted on the ground,' and was not all got in till after November I, so excessive was the wet and rain. And upon the dearth a sore death and mortality followed for want of necessary food to sustain the pining bodies of the poor people, who died so thick that there were great pits made in churchyards to lay the dead bodies in. And corn had been dearer if great store had not come out of Almaine, but there came fifty great ships with wheat and barley, meal and bread out of Dutchland, which greatly relieved the poor. ${ }^{5}$

1 Maitland, Domesday Book, p. 44 ; Cunningham, Grozoth of Industry and Commerce, i. I7I ; Domesday of S. Paul, pp. xliii. and xci.

${ }^{2}$ Cullum, History of Hawsted, p. 181 .

3 Rolls Series, ii. 220. According to this, the price of a bushel of wheat reckoned in modern money was $£_{3}$ in that year.

Ibid. iii. 220.

5 Holinshed, who is supported by William of Malmesbury in the assertion that in time of scarcity England imported corn. Matthew Paris, Chron. Maj., v. 673. 
Were the manors as isolated as some writers have asserted ? Generally speaking, we may say the means of communication were bad and many an estate cut off almost completely from the outside world, yet the manors must often have been connected by waterways, and sometimes by good roads, with other manors and with the towns. Rivers in the Middle Ages were far more used as means of communication than to-day, and many streams now silted up and shallow were navigable according to Domesday. Water carriage was, as always, much cheaper than land carriage, and corn could be carried from Henley to London for $2 d$. or $3 d$. a quarter. The roads left by the Romans, owing to the excellence of their construction, remained in use during the Middle Ages, and must have been a great advantage to those living near them; but the other roads can have been little better than mud tracks, except in the immediate vicinity of the few large towns. The keeping of the roads in repair, one part of the trinoda necessitas, was imposed on all lands; but the results often seem to have been very indifferent, and they appear largely to have depended on chance, or the goodwill or devotion of neighbouring landowners. ${ }^{1}$ Perhaps they would, except in the case of the Roman roads, have been impassable but for the fact that the great lords and abbots were constantly visiting their scattered estates, and therefore were interested in keeping such roads in order. But in those days people were contented with very little, and though Edward I enforced the general improvement of roads in 1285 , in the fourteenth century they were decaying. Parliament adjourned thrice between I 33 I and I 380 because the state of the roads kept many of the members away. In I 353 the high road running from Temple Bar, then the western limit of London, to Westminster was 'so full of holes and bogs' that the traffic was dangerous for men and carriages; and a little later all the roads near London were so bad, that carriers 'are oftentimes in peril of losing what they

${ }^{1}$ Jusserand, English Wayfaring Life, p. 79. 
bring.' What must remote country roads have been like when these important highways were in this state? If members of Parliament, rich men riding good horses, could not get to London, how did the clumsy wagons and carts of the day fare? The Church might well pity the traveller, and class him with the sick 'and the captive among the unfortunates whom she recommended to the daily prayers of pious souls.' 1 Rivers were mainly crossed by ford or ferry, though there were some excellent bridges, a few of which still remain, maintained by the trinoda necessitas, by gilds, by 'indulgences' promised to benefactors, and by toll, the right to levy which, called pontage, was often spent otherwise than on the repair of the bridge.

A few of the old open fields still exist, and the best surviving example of an open-field parish is that of Laxton in Nottinghamshire. ${ }^{2}$ Nearly half the area of the parish remains in the form of two great arable fields, and two smaller ones which are treated as two parts of the third field. The different holdings, freehold and leasehold, consist in part of strips of land scattered all over these fields. The three-course system is rigidly adhered to, first year wheat, second year spring corn, third year fallow.

In a corner of the parish is Laxton Heath, a common covered with coarse grass where the sheep are grazed according to a 'stint' recently determined upon, for when it was unstinted the common was overstocked. The commonable meadows which the parish once had were enclosed at a date beyond any'one's recollection, though the neighbouring parish of Eakring still has some. There are other enclosures in the remote parts of the parish which apparently represent the old woodland. The inconvenience of the common-field system was extreme. South Luffenham in Rutland, not enclosed till I 879 , consisted of

1 Jusserand, English Wayfaring Life, p. 89.

2 Gilbert Slater, The English Peasantry and the Enclosure of Common Fields, p. 8. 
1,074 acres divided among twenty-two owners into $1,23^{8}$ pieces. In some places furrows served to divide the lands instead of turf balks, which were of course always being altered. Another difficulty arose from there being no check to high winds, which would sometimes sweep the whole of the crops belonging to different farmers in an inextricable heap against the nearest obstruction. 


\section{CHAPTER II}

THE THIRTEENTH CENTURY. - THE MANOR AT ITS ZENITH, WITH SEEDS OF DECAY ALREADY VISIBLE. - WALTER OF HENLEY

IN the thirteenth century the manorial system may be said to have been in its zenith; the description therefore of Cuxham Manor in Oxfordshire at that date is of special interest. According to Professor Thorold Rogers ${ }^{1}$ there were two principal tenants, each holding the fourth part of a military fee. The prior of Holy Trinity, Wallingford, held a messuage, a mill, and 6 acres of land in free alms; i. e. under no obligation or liability other than offering prayers on behalf of the donor. A free tenant had a messuage and $3 \frac{3}{4}$ acres, the rent of which was 3 s. a year. He also had another messuage and nine acres, for which he paid the annual rent of $1 \mathrm{lb}$. of pepper, worth about Is. $3 d$. The rector of the parish had part of a furrow, i. e. one of the divisions of the common arable field, and paid $2 d$. a year for it. Another tenant held a cottage in the demesne under the obligation of keeping two lamps lighted in the church. Another person was tenant-at-will of the parish mill, at a rent of 40 s. a year. The rest of the tenants were villeins or cottagers, thirteen of the former and eight of the latter. Each of the villeins had a messuage and half a virgate, 12 to I.5 acres of arable land at least, for which his rent was chiefly corn and labour, though there were two money payments, a halfpenny on November I2 and a penny whenever he brewed. He had to pay a quarter of seed wheat at

1 Six Centuries of Work and Wages, p. 39. No one can write on English agriculture without acknowledging a deep debt to his monumental industry, though his opinions are often open to question. 
Michaelmas, a peck of wheat, 4 bushels of oats, and 3 hens on November I2, and at Christmas a cock, two hens, and two pennyworth of bread. His labour services were to plough, sow, and till half an acre of the lord's land, and give his work as directed by the bailiff except on Sundays and feast days. In harvest time he was to reap three days with one man at his own cost.

Some of these tenants held, besides their half virgates, other plots of land for which each had to make hay for one day for the lord, with a comrade, and received a halfpenny; also to mow, with another, three days in harvest time, at their own charges, and another three days when the lord fed them. After harvest six pennyworth of beer was divided among them, each received a loaf of bread, and every evening when work was over each reaper might carry away the largest sheaf of corn he could lift on his sickle.

The cottagers paid from Is. $2 d$. to $2 s$. a year for their holdings, and were obliged to work a day or two in the hay-making, receiving therefor a halfpenny. They also had to do from one to four days' harvest work, during which they were fed at the lord's table. For the rest of the year they were free labourers, tending cattle or sheep on the common for wages or working at the various crafts usual in the village. This manor was a small one, and contained in all twenty-four houscholds, numbering from sixty to seventy inhabitants. ${ }^{1}$

On most manors, as in Forncett ${ }^{2}$, which contained about $2,7 \mathrm{co}$ acres, from the preponderance of arable, the chief source of income to the lord was from the grain crops; other sources may be seen from the following table of the lord's receipts and expenses in $1272-3$ :

1 Compare the account of the manors in Huntingdonshire belonging to Romsey Abbey given in Page, End of Villeinage in England, pp. 28 et seq.

2 Davenport, A Norfolk Manor, p. 36; and see Hall, Pipe Roll of Bishopric of Winchester, p. xxv. 
RECEIPTS.

Fixed rents $\quad £$ s. $d$.

Farm of market . . 026

Chevage $^{1}$. . . 086

Foldage . . . $039 \frac{1}{2}$

Sale of works . . $5132 \frac{3}{4}$

Herbage . . . I 04

Hay . . . 212 II

Turf, \&c. . . . I $136 \frac{1}{2}$

Underwood . 5102

Grain . . . 6I $12 \quad 3 \frac{x}{4}$

Cider . . . I I II $\frac{1}{4}$

Stock . . . 530

Dairy . . . $430 \frac{3}{4}$

Pleas : . . 1400

Tallage . . 6134

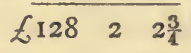

EXPENSES.

Rents paid and allowed $\begin{array}{cccc}E & s . & d . \\ 0 & 3 & 2 \frac{1}{2}\end{array}$ Ploughs and carts . 2174 Buildings and walls . $4510 \frac{1}{2}$ Small necessaries . $\quad 0 \quad 7 \quad 10_{4}^{3}$ Dairy . . . $043 \frac{3}{4}$ Threshing • . . I $155 \frac{1}{2}$ Meadow and autumn expenses . Stock .

Bailiff

Steward

Grain .

Expenses of acct.

$$
\begin{array}{rrrl}
. & 0 & 1 & 4 \\
. & 0 & 16 & 7 \\
. & 1 & 19 & 0 \\
. & 1 & 6 & 9 \frac{1}{2} \\
. & 8 & 2 & 4 \frac{1}{4} \\
. & 1 & 0 & 8 \frac{1}{2}
\end{array}
$$

$\lcm{623 \quad 0 \quad 9 \frac{3}{4}}$

The manor was almost entirely self-sufficing; of necessity, for towns were few and distant, and the roads to them bad. Each would have its smith, millwright, thatcher, \&c., paid generally in kind for their services. There was little trade with the outside world, except for salt-an invaluable article when meat had to be salted down every autumn for winter use, since there were no roots to keep the cattle on-and iron for some of the implements. Nearly everything was made in the village.

The mediaeval system of tillage was compulsory; even the freeholders could not manage their plots as they wished, because all the soil of the township formed one whole and was managed by the entire village. Even the lord ${ }^{2}$ had to conform to the customs of the community. Any other system than this, which must have been galling to the more enterprising, was impossible, for as the various holdings lay in unfenced strips all over the great common fields, individual initiative was

1 Chevage, poll money, paid to the lord.

${ }^{2}$ Vinogradoff, Villeinage in England, p. 230. 
out of the question. As may be imagined, the great number of strips all mixed together often led to great confusion, sometimes 2 or 3 acres could not be found at all, and disputes owing to careless measurement were frequent.

It is not surprising that the services by which the villeins paid rent for their holdings to the lord very early began to be commuted for money; it was much more convenient to both parties; and with this change from a 'natural economy' to a 'money economy' the destruction of the manorial system commenced, though it was to take centuries to effect it.

The first money payments apparently date from as early as $900,{ }^{1}$ but must then have been very few, and services were the rule in the thirteenth and earlier centuries, though at the beginning of the twelfth we find a great number of rent-paying tenants. ${ }^{2}$ In the fourteenth century money began to be more generally available, and the process of commutation grew steadily; a process greatly accelerated by the destruction of large numbers of tenants who paid rent in services by the Black Death of $1348-9$, which forced lords of manors to let their lands for money or work them themselves with hired labour. Before that visitation, however, it appears that commutation of labour services for fixed annual payments had made very little progress. ${ }^{3}$

When these services were commuted for money in the thirteenth and fourteenth centuries they were put at $I d$. a day in winter, and $2 d$. a day in summer, and rather more in harvest $;^{4}$ and we may put the ordinary agricultural labourers' wages from $125^{\circ-1} 35^{\circ}$ all the year round at $2 d$. a day, and from $135^{\circ-}$

1 Cunningham, Industry and Commerce, i. 117.

${ }^{2}$ Vinogradoff, Villeinage in England, p. 307. On the Berkeley estates in 1 189-1220 money was so scarce with the tenants that the rents, apparently even where services had been commuted, were commonly paid in oxen.-Smyth, Lives of the Berkeleys, i. 101. In the thirteenth century the labour services of the villeins were stricter than in the eleventh. Vinogradoff, op. cit. 298.

Page, End of Villeinage, p. 39.

4 Thorold Rogers, History of Agriculture and Prices, i. 82. 
1400 at $3 d$., but few were paid in this way. Many were paid by the year, with allowances of food besides and sometimes clothes, and many were in harvest at all events paid by the piece. At Crondal in Hampshire in 1248 a carter by the year received $4 s$. , a herdsman $2 s$. $3 d$., a daya or dairymaid, $2 s^{1}$ The change to money payments was beneficial to both parties; it stopped many of the dishonest practices of the lord's bailiff, apart from the fact that farming by officials was an expensive method. It meant, too, that religious festivals and bad weather would no longer diminish the lord's profits; on the other hand, the tenant could devote himself entirely to his holding free from annoying labour services. ${ }^{2}$

The state of agriculture at the time of Domesday was apparently very low, judging by the small returns of manors, ${ }^{3}$ but by the time of Edward I it had made considerable progress. During the reign of Henry III England had grown in opulence, and continued to do so under his great son, who found time from his manifold tasks to encourage agriculture and horticulture. Fruit and forest trees, shrubs and flowers, were introduced from the continent, and we are told that the hop flourished in the royal gardens. ${ }^{4}$ At his death England was prosperous, the people progressing in comfort, the population advancing, the agricultural labourers were increasing in numbers, the value of the land had risen and was rising. Then came a reaction from which England did not recover for two centuries, and Harrison, who wrote his description of England at the end of the sixteenth century, says that many of the improvements began to be neglected in process of time, so that from Henry IV till the latter end of Henry VII there was little or no use for them in England, 'but they remained unknown.'

The Hundred Rolls of Edward I, which embody the results

1 Hampshire Record Society, i. 64. See Appendix, i.

2 Hasbach, English Agricullural Labourer, p. 14.

3 Hallam, Middle Ages, iii. 36r.

4 Denton, England in the Fiftecnth Century, p. 56. 
of the labours of a commission appointed by that monarch to inquire into encroachments on royal lands and royal jurisdiction, show clearly that there had been since the Domesday Survey a very great growth in the rural population, a sure sign that agriculture was flourishing; and on some estates the number of free tenants had increased largely, but the burdens of the villeins were not less onerous than they had been.

It was in the thirteenth century that the practice of keeping strict and minute accounts became general, and the accounts of the bailiff of those days would be a revelation to the bailiff of these.

At the same time we must not forget that the earliest improvements in English agriculture were largely due to the monks, who from their constant journeys abroad were able to bring back new plants and seeds; while it is well known that many of the religious houses, the Cistercians especially, who always settled in the remote country, were most energetic farmers, their energy being materially assisted by their wealth. It is said that the great Becket when he visited a monastery did not disdain to labour in the field.

Among other benefits that the landed interest gained at this time was the more easy transference of land provided, inter alia, by the statute of Quia Emptores, which led to many tenants selling their lands, provided the rights of the lord were preserved, and to a great increase consequently of free tenants, many of whom had quite small holdings. ${ }^{1}$ The amalgamation of holdings by the more industrious and skilful has, as we should expect, been a well-marked tendency all through the history of English agriculture, and began early. For instance, according to the records of S. Paul's Cathedral, John Durant, whose ancestor in 1222 held only one virgate in 'Cadendon', had in 1279 eight or ten at least. At 'Belchamp', Martin de Suthmere, one of the free tenants, held 245 acres by himself and his tenants, twenty-two in number, who rendered

${ }^{1}$ Cunningham, Industry and Commerce, i. 273. 
service to him; one of them being de Vere, Earl of Oxford, who held $I 7$ acres under Martin. To such a position had the abler of the small holders of a century or so before already pushed their way, in spite of the heavy hand of feudalism, which did much to hinder individual initiative. At this period and until Tudor times England, as regards the cultivated land, was essentially a corn-growing country; the greater part of the lord's demesne was arable, and the tillage fields of the villeins largely exceeded their meadows. For instance, in 1285 the cultivated lands at Hawsted in Suffolk were nearly all under the plough; in seven holdings there were 968 acres of arable and only 40 of meadow, a proportion of 24 to $I$. No doubt there was plenty of common pasture, but we cannot call this cultivated land. The seven holdings were as follows : 1

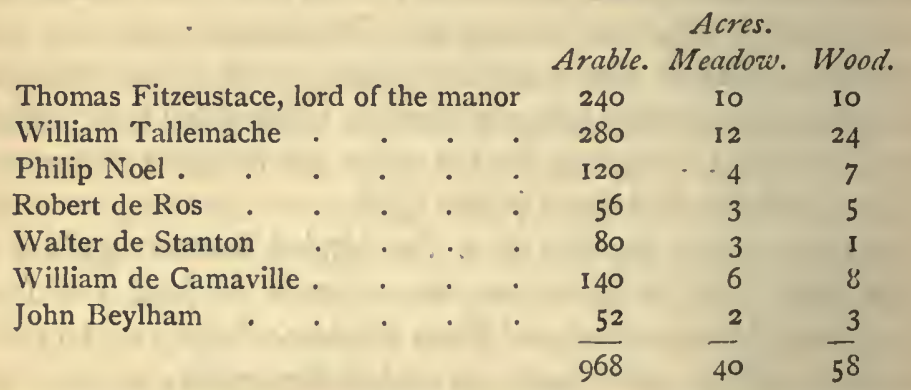

These were the larger tenants; among the smaller several had no meadow at all.

We must not forget that the grazing of the tillage fields after the crops were off was of great assistance to those who kept stock; for there was plenty to eat on the stubbles. The wheat was cut high, the straw often apparently left standing 18 inches or 2 feet high; weeds of all kinds abounded, for the land was badly cleaned; and often only the upper part of the high ridges, into which the land was thrown for pur-

${ }^{1}$ Cullum, History of Hazusted, 1784 ed., p. 180. 
poses of drainage, was cultivated, the lower parts being left to natural grass. ${ }^{1}$

The greatest authority for the farming of the thirteenth century is Walter of Henley, who wrote, about the middle of it, a work which held the field as an agricultural textbook until Fitzherbert wrote in the sixteenth century, and much of his advice is valuable to-day. There was from his time until the days of William Marshall, who wrote five centuries afterwards, a controversy as to the respective merits of horses and oxen as draught animals, and it is a curious fact that the later writer agreed with the earlier as to the superiority of oxen. 'A plough of oxen', says Walter, 'will go as far in the year as a plough of horses, because the malice of the ploughman will not allow the plough of horses to go beyond their pace, no more than the plough of oxen. Further, in very hard ground where the plough of horses will stop, the plough of oxen will pass. And the horse costs more than the ox, for he is obliged to have the sixth part of a bushel of oats every night, worth a halfpenny at least, and twelve pennyworth of grass in the summer. Besides, each week he costs more or less a penny a week in shoeing, if he must be shod on all four feet;' which was not the universal custom.

'But the ox has only to have $3 \frac{1}{2}$ sheaves of oats per week (ten sheaves yielding a bushel of oats), worth a penny, and the same amount of grass as the horse. ${ }^{2}$ And when the horse is old and worn out there is nothing but his skin, but when the ox is old with ten pennyworth of grass he shall be fit for the larder.' 3

The labourer of the Middle Ages could not complain of lack of holidays; Walter of Henley tells us that, besides Sundays, eight weeks were lost in the year from holidays and other hindrances. ${ }^{4}$

1 Ballard, Domesday, p. 207.

2 Walter of Henley, Royal Historical Society, p. I2.

3 Walter reckons the above food of the horse at $12 s .3 d$., and of the ox at $3 s$. $1 d$. ; but both are wrong. 
He advises the sowing of spring seed on clay or on stony land early, because if it is dry in March the ground will harden too much and the stony ground become dry and open; therefore sow early that corn may be nourished by winter moisture. Chalky and sandy ground need not be sown early. At sowing, moreover, do not plough large furrows, but little and well laid together, that the seed may fall evenly. Let your land be cleaned and weeded after S. John's Day, June 24, for before that is not a good time; and if thistles are cut before S. John's Day 'for every one will come two or three.' 'Do not sell your straw; if you take away the least you lose much; words which many a landlord to-day doubtless wishes were fixed in the minds of his tenants.

Manure should be mixed with earth, for it lasts only two or three years by itself, but with earth it will last twice as long; for when the manure and the earth are harrowed together the earth shall keep the manure so that it cannot waste by descending in the soil, which it is apt to do.

'Feed your working oxen before some one, and with chaff. Why? I will tell you. Because it often happens that the oxherd steals the provender.'

The oxen were also to be bathed, and curried when dry with a wisp of straw, which would cause them to lick themselves.

'Change your seed every year at Michaelmas; for seed grown on other ground will bring more profit than that which is grown on your own.'

Apparently the only drainage then practised was that of furrow and open ditch; and we find him saying that to free your lands from too much water, let the marshy ground be well ridged, and the water made to run, and so the ground may be freed from water.

Here is his estimate of the cost of wheat growing ${ }^{1}$ :

'You know surely that an acre sown with wheat takes three 1 Walter of Henley, Royal Historical Society, p. 19. 
ploughings, except lands which are sown yearly; and that each ploughing is worth $6 d$. and the harrowing $I d$., and on the acre it is necessary to sow at least two bushels. Now two bushels at Michaelmas are worth at least $\mathrm{J} 2 d$., and weeding $\frac{1}{2} d$., and reaping $5 d$., and carrying in August $I d$., and the straw will pay for the threshing.'

The return was wretched: 'at three times your sowing you ought to have 6 bushels, worth $3 s$. ' The total cost is thus $3^{s .} 1 \frac{1}{2} d$.; and without debiting anything for rent and manure, the loss would be $1 \frac{1}{2} d$. an acre.

The anonymous Treatise on Husbandry of about the same date says, however, that ' wheat ought to yield to the fifth grain, oats to the fourth, barley to the eighth, beans and peas to the sixth.' In the years $1243-8$ the average yield of wheat at Combe, Oxfordshire, was 5 bushels per acre, of barley a little over 5, oats 7 . In the Manor of Forncett, in various years from 1290 to 1306 , wheat yielded about 10 bushels, oats from 12 to 16 , barley 16 , and peas from 4 to 12 bushels per acre. ${ }^{2}$

As for the dairy, 2 cows, says Walter, should yield a wey, ( 2 cwt.) of cheese annually, and half a gallon of butter a week, 'if sorted out and fed in pasture of salt marsh;' but 'in pasture of wood or in meadows after mowing, or in stubble, it should take 3 cows for the same.' Twenty ewes, which it was then the custom to milk, fed in pasture of salt marsh, ought to yield the same as the 2 cows. A gallon of butter was worth $6 d$., and weighed $7 \mathrm{lb}$. And the anonymous treatise says each cow ought to yield from the day after Michaelmas until the first kalends of May, twenty-eight weeks, Iod. more or less; and from the first kalends of May till Michaelmas, twenty-four weeks, the milk of a cow should be worth $35.6 \mathrm{~d}$; and she should give also 6 stones ( $14 \mathrm{lb}$. per stone) of cheese, and 'as

1 Walter of Henley, Royal Historical Society, p. 7 I.

3 Davenport, $A$ Norfolk Manor, pp. 29 et seq. See also Hall, Pipe Roll of the Bishopric of Winchester, p. xxvi, which gives an average yield of wheat over a large area in $1298-9$ at 4.3 bushels per acre.

CURTLER 
much butter as shall make as much cheese.' It was a common practice all through the Middle Ages, and survives in some localities to-day, to let out the cows by the year, at from 5 s. to $6 s .8 d$. a head, often to the daya or dairymaid, the owner supplying the food, and the lessee agreeing to restore them in equal number and condition at the end of the term. ${ }^{2}$ The anonymous treatise tells us that 'if you wish to farm out your stock you can take $4 s$. $6 d$. clear for each cow and acquit the tithe, and for a sheep $6 d$. and the tithe, and a sow should bring you $6 s .6 d$. a year and acquit the tithe, and each hen $9 d$. and the tithe; and Walter says, "When I was bailiff the dairymaids had the geese and hens to farm, the geese at $12 d$. and the hens at $3 d$.'

Among other information conveyed by these two treatises we learn that the poor servants or labourers were accustomed to be fed on the diseased sheep, salted and dried; but Walter adds, 'I do not wish you to do this.' Nor can we point the finger of scorn at this: for in the disastrous season of 1879 numbers of rotten sheep were sold to the butcher and consumed by the unsuspecting public without even being salted and dried.

He further tells us that 'you can well have 3 acres weeded

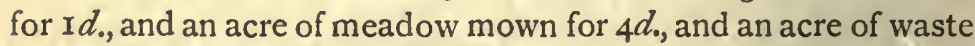
meadow for $3 \frac{1}{2} d$. And know that 5 men can well reap and bind 2 acres a day of each kind of corn, and where each takes $2 d$. a day then you must give $5 d$. an acre.' 3 'One ought to thresh a quarter of wheat or rye for $2 d$. and a quarter of oats for Id. A sow ought to farrow twice a year, having each time at least 7 pigs; and each goose 5 goslings a year, and each

1 Walter of Henley, Royal Historical Society, p. 77. $28 \mathrm{r}$.

2 Thorold Rogers, Agriculture and Prices, i. 397 ; Archaeologia, xviii.

3 Walter of Henley, pp. 69, 75. In Lancashire, at the end of the thirteenth century, mowing $60 \frac{1}{2}$ acres cost 175 . $7 \frac{3}{4} d$. Victoria County History, Lancashire, Agriculture, and Two Compoti of the Lancashire and Cheshire Manors of Henry de Lacy (Cheetham Society). 
hen I I 5 eggs and 7 chicks, 3 of which ought to be made capons ; and for 5 geese you must have one gander, and for 5 hens one cock.' The laying qualities of the hen, in spite of the talk of the 200-egg bird, were evidently as good then as to-day. In those days of self-supporting farms it was the custom to put together the farm implements at. home, and the farmer is advised that it will be well if he can have carters and ploughmen who should know how to work all their own wood, though it should be necessary to pay them more. ${ }^{1}$ The village smith, however, seems, as we should expect, to have done most of the iron work that was needed. ${ }^{2}$

These extracts have given the reader some insight into thirteenth-century prices, prices which in the case of grain altered very little for nearly 300 years: for instance, the average price of wheat from 1259 to 1400 was 5 s. $10 \frac{3}{4} d$. a quarter, and from 140 I to I 5405 s. 1 I $\frac{3}{4} d$. ; of barley, $4 s .3 \frac{3}{4} d$. from 1259 to $1400,3 s .8 \frac{3}{4} d$. from 1401 to I 540 ; of oats, 2s. $5 \frac{3}{4} d$. and $2 s .2 \frac{1}{4} d$. in the same two periods respectively; of rye, $4 s .5 d$. and $4 s .7 \frac{3}{4} d$.; and of beans, $4 s .3 \frac{1}{2} d$. and $3 s .9 \frac{1}{4} d .{ }^{3}$

Wheat fluctuated considerably, being as we have seen 2s. a quarter at Hawsted in 1243 and in I $290 \mathrm{I} 45$. Iod., a most exceptional price. Oxen, which were chiefly valued as working animals, were about $13 s$. apiece ${ }^{4}$; cows, 9s. $5 d$. Farm horses were of two varieties: the 'affer' or 'stott', a rough small animal, generally worth about $\mathrm{I} 3 s$. $5 d$., and the cart-horse, probably the ancestor of our shire horses, whose

1 Walter of Henley, p. 63.

2 Crondall, Records, Hampshire Record Society, i. 65.

3 See Thorold Rogers, various tables in vol. i. of History of Agriculture and Prices. Compare these with the prices on the Berkeley estates from 1281 to 1307 , omitting years of scarcity: wheat, $2 s .4 d$. to $5 s$.; oxen, IOs. to I2s.; cows, 9s. to Ios. ; bacon hogs, 5s.; fat sheep, Is. $6 d$. to $2 s$. ; and in the early part of Edward III's reign, wheat, $5 s .4 \pi$. to IOs.; oxen, 14s. to 24s. Other prices about the same.-Smyth, Lives of the Berkeleys, i. 160.

- If it is true, as generally stated, that the mediaeval ox was one-third the size of his modern successor, it is apparent that he was a very dear animal. Cattle at this date suffered from the ravages of wolves. 
average price was I9s. 4d. A good saddle-horse fetched as much as 65 . Sheep were from Is. $2 d$. to Is. $5 d$. each. In Hampshire in 1248 shoeing ten farm horses for the plough for a year cost 5 s.; making a gate cost $12 d$. As Walter of Henley said, it cost a penny a week to shoe a horse on all four feet; these horses must have been very roughly shod.' It is evident, from what Walter of Henley says, that horses were not always shod on all four feet, and their shoes were generally very light. The roads were mere tracks without any metalling, so that there was little necessity for heavy shoes; and as Professor Thorold Rogers suggests, it is quite possible that the hoofs of our horses have become weaker by reason of the continual paring and protection which modern shoeing involves ${ }^{2}$. They weighed usually less than half a pound, and cost about 45 . a hundred.

The most striking fact about agricultural prices at this date is the low price of land compared with that of its products. The annual rent of land was from $4 d$. to $6 d .^{3}$ an acre, and it was worth about ten years' purchase. Consequently, a quarter of wheat was often worth more than an acre of land, a good ox three times as much, a good cart-horse four times, while a good war-horse was worth the fee-simple of a small farm. A greater breadth of wheat was sown than of any other crop; but it seems that none was ever stored except in the castles and monasteries, for in spite of successive abundant harvests a bad season would send the price up at once. Barley was, as now, chiefly used for making beer, which was also made from oats and wheat, of course without hops, which were not used till the fifteenth century; and sometimes it was made of oats, barley, and wheat, a concoction worth $\frac{3}{4} d$. a gallon in

1 Crondall, Records, Hampshire Record Society, i. 64.

2 History of Agriculture and Prices, i. 528.

S Seebohm, Transactions of Royal Historical Society, New Series, xvii. 288 , says that rent in the fourteenth century was commonly $4 d$.; the usual average is stated at $6 d$. an acre. 
I 283. Cider was also drunk, and was sold at Exminster in Devonshire in 1286 at $\frac{1}{2} d$. a gallon, and apples fetched $2 d$. a bushel. Thorold Rogers ${ }^{2}$ says that wheat was the chief food of the English labourer from the earliest times until perhaps the seventeenth century, when the enormous prices were prohibitive; but this statement must be taken with reserve, as must that of $\mathrm{Mr}$. Prothero ${ }^{3}$ that rye was the bread-stuff of the peasantry. Where the labourer's food is mentioned as part of his wages, wheat, barley, and rye all occur, wheat and rye being often mixed together as 'mixtil'; and it is most probable that in one district wheat, in another one of the other cereals, formed his chief bread-stuff, according to the crop best adapted to the soil of the locality.

Walter of Henley mentions wheat as if it was the chief crop, for he selects it as best illustrating the cost of corn-growing ${ }^{4}$; and from the enormous number of entries enumerated by Thorold Rogers in his mediaeval statistics it was apparently more grown than other cereals. The chief meat of the lower classes then, as to-day, was bacon from the innumerable herds of swine who roamed in the woods and wastes, but in bad years, when food was scarce, the poor ate nuts, acorns, fern roots, bark, and vetches. ${ }^{5}$

As the cattle of the Middle Ages were like the mountain cattle of to-day, so were the sheep like many of the sheep to be seen in the Welsh mountains; yet, unlike the cattle, an attempt seems to have been made, judging by the high price of rams, to improve the breed; but they were probably poor animals worth from Is. to Is. $6 d$. each, with a small fleece weighing about a pound and a half, worth $3 d$. a lb. or a little more.

1 Domesday of S. Paul, Camden Society, p. li.

2 History of Agriculture and Prices, i. 26.

3 Pioneers of Agriculture, p. I 3.

4 Ed. Lamond, Royal Historical Society, p. 19.

5 Denton, England in the Fifteenth Century, p. 93. 


\section{CHAPTER III}

THE FOURTEENTH CENTURY.-DECLINE OF AGRICULTURE.-THE BLACK DEATH.-STATUTE OF LABOURERS

AFTER the death of Edward I in 1307 the progress of English agriculture came to a standstill, and little advance was made till after the battle of Bosworth in $1_{485}$. The weak government of Edward II, the long French War commenced by Edward III and lasting over a hundred years, and the Wars of the Roses, all combined to impoverish the country. England, too, was repeatedly afflicted during the fourteenth and fifteenth centuries by pestilences, sometimes caused by famines, sometimes coming with no apparent cause; all probably aggravated, if not caused, by the insanitary habits of the people. The mention of plagues, indeed, at this time is so frequent that we may call them chronic.

At this period corn and wool were the two main products of the farmer; corn to feed his household and labourers, and wool to put money in his pocket, a somewhat rare thing.

English wool, which came to be called 'the flower and strength and revenue and blood of England', was famous in very early times, and was exported long before the Conquest. In Edgar's reign the price was fixed by law, to prevent it getting into the hands of the foreigner too cheaply; a wey, or weigh, was to be sold for $120 d^{1}$ Patriotic Englishmen asserted it was the best in the world, and Henry II, Edward III, and Edward IV are said to have improved the Spanish breed by presents of English sheep. Spanish wool, however, was con sidered the best from the earliest times until the Peninsular

${ }^{1}$ Cunningham, Grozuth of English Industry and Commerce, i. I30. A weigh in the Middle Ages was $182 \mathrm{lbs}$., or half a sack. 
War, when the Saxon and Silesian wools deposed it from its pride of place. Smith, in his Memoirs of Wool, ${ }_{1}^{1}$ is of the opinion that England 'borrowed some parts of its breed from thence, as it certainly did the whole from one place or another.' Spanish wool, too, was imported into England at an early date, the manufacture of it being carried on at Andover in $1262 .{ }^{2}$ Yet until the fourteenth century it was not produced in sufficient quantities to compete seriously with English wool in the markets of the Continent ; and it appears to have been the long wools, such as those of the modern Leicester and Lincoln, from which England chiefly derived its fame as a wool-producing country.

Our early exports went to Flanders, where weaving had been introduced a century before the Conquest, and, in spite of the growth of the weaving industry in England, to that country the bulk of it continued to go, all through the Middle Ages, though in the thirteenth century a determined effort was made to divert a larger share of English wool to Italy. ${ }^{3}$ During the thirteenth and fourteenth centuries the export of wool was frequently forbidden, ${ }^{4}$ sometimes for political objects, but also to gain the manufacture of cloth for England by keeping our wool from the foreigner; but these measures did not stop the export, they only hampered it and encouraged much smuggling. It commanded what seems to us an astonishing price, for $3 d$. a lb. in the thirteenth and fourteenth centuries is probably equal to nearly $4 s$. in our money. Its value, and the ease with which it could be packed and carried, made it an object of great importance to the farmer. In $1337^{5}$ we have a schedule of the price

1 Second edition, i. $50 n$. See also Burnley, History of Wool, p. 17.

2 Gross, Gild Merchant, ii. 4. It is from the Spanish merino, crossed with Leicesters and Southdowns, that the vast Australian flocks of to-day are descended.

Cunningham, op. cit. i. 628.

1 Ashley, Early History of English Woollen Industry, p. 34.

5 Calendar of Close Rolls, $1337-9$, pp. 148-9. 
of wool in the various counties of England, for in that year 30,000 sacks of the best wool was ordered to be bought in various districts by merchants for Edward III, to provide the sinews of war against France. The price for the best wool was to be fixed by the king, his council, and the merchants; the 'gross' wool being bought by agreement between buyer and seller. Of the former the highest price fixed was for the wool of Hereford, then and for long afterwards famous for its excellent quality, I2 marks the sack of $3^{64} \mathrm{lb}$; and the lowest for that of the northern counties, 5 marks the sack.

Somewhat more than a century afterwards we have another similar list of wool prices, when in 1454 the Commons petitioned the king that 'as the wools growing within this realm have hitherto been the great commodity, enriching, and welfare of this land, and how of late the price is greatly decayed so that the Commons were not able to pay their rents to their lords', the king would fix certain prices under which wools should not be bought. The highest price fixed was for the wool of 'Hereford, in Leominster', $£ \mathrm{I} 3$ a sack; the lowest for that of Suffolk, $£^{2} \mathrm{I}_{2 s}{ }^{1}$; the average being about $£ 4$ Ios.

The manorial accounts of the Knights' Hospitallers, who then held land all over England, afford valuable information as to agriculture in $133^{8.2}$ From these we gather that the rent of arable land varied from $2 d$. to $2 s$. an acre ; but the latter sum was very exceptional, and there are only two instances of it given, in Lincolnshire and Kent. Most of the tillage rented for less than Is. an acre, more than half being at $6 d$. or under, and the average about $6 d$. On the other hand, meadow land is seldom of less value than $2 s$. an acre, and in Warwickshire, Oxfordshire, and Norfolk rose to $3 s$. This is one of the numerous proofs of the great value of meadow land at a time

2 The Hospitallers in England, Camden Society. 
when hay was almost the sole winter food of stock ; in some places it was eight or ten times as valuable as the arable. ${ }^{1}$ The pasture on the Hospitallers' estates was divided into several and common pasture, the former often reaching Is. an acre and sometimes $2 s$., the latter rarely exceeding $4 d$. The most usual way, however, of stating the value of pasture was by reckoning the annual cost of feeding stock per head, cows being valued at $2 s$., oxen at Is., a horse at a little less than an ox, a sheep at $I d$. The reign of Edward III was a great era for wool-growers, and the Hospitallers at Hampton in Middlesex had a flock of 2,000 sheep whose annual produce was six sacks of wool of $364 \mathrm{lb}$. each, worth $£ 4$ a sack, which would make the fleeces weigh a little more than I lb. each. The profit of cows on one of their manors was reckoned at $2 s$. per head, on another at $3 s$. ; and the profit of roo sheep at $20 s^{2}$ The wages paid to the labourers for day work were $2 d$. a day, and we must remember that when he was paid by the day his wages were rightly higher than when regularly employed, for day labour was irregular and casual. The tenants about the same date obtained the following prices for some of their stock ${ }^{3}:-$

A good ox, alive, fatted on corn .

$$
\begin{aligned}
& £ \text { s. } d \text {. } \\
& " \quad " \quad \text { not on corn . . . . } 160
\end{aligned}
$$

A fatted cow

A two-year-old hog

A sheep and its fleece

A fatted sheep, shorn .

Hens, each ${ }^{4}$

20 eggs

In the middle of the fourteenth century occurred the famous Black Death, the worst infliction that has ever visited England.

1 Denton, England in the Fifteenth Century, p. 147.

2 Hospitallers in England, p. xxvi. .

4 Poultry-keeping was wellnigh universal, judging by the number of rents paid in fowls and eggs. 
Its story is too well known for repetition, and it suffices to say that it was like the bubonic plague in the East of to-day: it raged in $1348-9$, and killed from one-third to one-half of the people. ${ }^{1}$ It is said to have effected more important economic results than any other event in English history. It is probable that the prices of labour were rising before this terrible calamity; the dreadful famine of $1315-6,{ }^{2}$ followed by pestilence, when wheat went up to $26 s$. a quarter, and according to the contemporary chroniclers, in some cases much higher, destroyed a large number of the population, and other plagues had done their share to make labour scarce, but after the Black Death the advance was strongly marked. It also accelerated the break-up of the manorial system. A large number of the free labourers were swept away, and their labour lost to the lord of the manor; the services of the villeins were largely diminished from the same cause; many of the tenants, both free and unfree, were dead, and the land thrown on the lord's hands. Flocks and herds were wandering about over the country because there was no one to tend them. In short, most manors were in a state of anarchy, and their lords on the verge of ruin. It is not to be wondered at, therefore, that they immediately adopted strong measures to save themselves and their property and, no doubt they thought, the whole country. Englishmen had by this time learnt to turn to Parliament to remedy their ills, but as the plague was still raging a proclamation was issued of which the preamble states

1 I 348 seems also to have been an excessively rainy year. The wet season was very disastrous to live stock; according to the accounts of the manors of Christ Church, Canterbury, about this time (Historical MSS. Commission, 5th Report, 444) there died of the murrain on their estates 257 oxen, 5 I I cows, 4,585 sheep. Murrain was the name given to all diseases of stock in the Middle Ages, and is of constant occurrence in old records.

2 The cause of this as usual was incessant rain during the greater part of the summer; the chroniclers of the time say that not only were the crops very short but those that did grow were diseased and yielded no nourishment. The 'murrain' was so deadly to oxen and sheep that, according to Walsingham, dogs and ravens eating them dropped down dead. 
that wages had already gone up greatly. 'Many, seeing the necessity of masters and great scarcity of servants, will not serve unless they get excessive wages', and it is, therefore, hard to till the land. Every one under the age of 60 , it was ordered, free or villein, who can work, and has no other means of livelihood, is not to refuse to work for any one who offers the accustomed wages; no labourer is to receive more wages than he did before the plague, and none are to give more wages under severe penalties. But besides regulating wages, the proclamation also insists on reasonable prices for food and the necessaries of life : it was a fair attempt not only to protect the landlords but the labourers also, by keeping both wages and prices at their former rate, so that its object was not tyrannous as has been stated. ${ }^{1}$ It was at once disregarded, a fate which met many of the proclamations and statutes of the Middle Ages, which often seem to have been regarded as mere pious aspirations.

Accordingly, the Statute of I35I, 25 Edw. III, Stat. 2, c. I, states that the servants had paid no regard to the ordinance regulating wages, 'but to their ease and singular covetise do withdraw themselves unless they have livery and wages to the double or treble of that they were wont to take'. Accordingly, it was again laid down that they were to take liveries and wages as before the Black Death, and 'where wheat was wont to be given they shall take for the bushel rod. (6s. $8 d$. a quarter), ${ }^{2}$ or wheat at the will of the giver. And that they be hired to serve by the whole year or by other usual terms, and

1 See Cunningham, Industry and Commerce, i. 335. Also in an age when the idea of Competitive price had not yet been evolved, and when regulation by authority was the custom, it was natural and right that the Government in such a crisis should try to check the demands of both labourers and producers, which went far beyond what employers or consumers could pay. Putnam, Enforcement of the Statute of Labourers, 220.

2 The average price of wheat in I35 I was IOS. $2 \frac{1}{2} d$., which went down to $7 s .2 d$. next year, and $4 s .2 \frac{1}{2} d$. the year after; but judging by the ineffectiveness of the statute to reduce wages, it probably had little effect in causing this fall. 
not by the day, and that none pay in the time of sarcling (weeding) or hay-making but a penny a day, and a mower of meadows for the acre $5 d$., or by the day $5 d$., and reapers of corn in the first week of August 2d., and the second $3 d$., without meat or drink:' And none were to take for the threshing of a quarter of wheat or rye more than $2 d$., and for the quarter of beans, peas, and oats more than $I d$. These prices are certainly difficult to understand. Hay-making has usually been paid for at a rate above the ordinary, because of the longer hours; and here we find the price fixed at half the usual wages, while mowing is five times as much, and double the price paid for reaping, though they were normally about the same price. ${ }^{1}$

It is interesting to learn from the statute that there was a considerable migration of labourers at this date for the harvest, from Stafford, Lancaster, Derby, Craven, the Marches of Wales and Scotland, and other places.

Such was the first attempt made to control the labourers' wages by the legislature, and like other legislation of the kind it failed in its object, though the attempt was honestly made; and if the rate of wages fixed was somewhat low, its inequity was far surpassed by the exorbitance of the labourers' demands. ${ }^{2}$ It was an endeavour to set aside economic laws, and its futility was rendered more certain by the depreciation of the coinage in $\mathrm{I} 35 \mathrm{I}$, which led to an advance in prices, and compelled the labourers to persevere in their demands for higher wages. ${ }^{3}$

Both wages and prices, except those of grain, continued to

1 See Appendix I.

2 Putnam, op. cit. 221. The statute for the first ten years, however, kept wages from ascending as high as might have been the case.

${ }^{3}$ McPherson, Annals of Commerce, i. 543, says that as the plague diminished the number of employers as well as labourers, the demand for labour could not have been much greater than before, and would have had little effect on the rate of wages if Edward III had not debased the coinage. But if the owners did decrease the lands would only accumulate in fewer hands, and would still require cultivation. 
increase, and labour services were now largely commuted for money payments, ${ }^{1}$ with the result that the manorial system began to break up rapidly

Owing to the dearth of labourers for hire, and the loss of many of the services of their villeins, the lords found it very hard to farm their demesne lands. It should be remembered, too, that an additional hardship from which they suffered at this time was that the quit rents paid to them in lieu of services by tenants who had already become free were, owing to the rise in prices, very much depreciated. Their chief remedy was to let their demesne lands. The condition of the Manor of Forncett in Norfolk well illustrates the changes that were now going on. There, in the period $1272-1307$, there were many free tenants as well as villeins, and the holdings of the latter were small, usually only 5 acres. It is also to be noticed that in no year were all the labour services actually performed, some were always sold for money. Yet in the period named there was not much progress in the general commutation of services for money payments, and the same was the case in the manors, whose records between 1325 and $1350 \mathrm{Mr}$. Page examined for his End of Villeinage in England. ${ }^{2}$ The reaping and binding of the entire grain crop of the demesne at Forncett was done by the tenants exclusively, without the aid of any hired labour. ${ }^{3}$

However, in the period $1307-1376$ the manor underwent a great change. The economic position of the villeins, the administration of the demesne, and the whole organization of the manor were revolutionized. Much of the tenants' land had reverted to the lord, partly by the deaths in the great pestilence, partly because tenants had left the manor ; they had run away and left their burdensome holdings in order to get high wages as free labourers. This of course led to a diminution of labour rents, so the landlord let most of the demesne for a term of

${ }^{2}$ Page, End of Villeinage, pp. 59 et seq. ${ }^{2}$ Ibid. p. 44.

3 Transactions, Royal Historical Society, New Series, xiv. 123. 
years, ${ }^{1}$ a process which went on all over England; and thus we have the origin of the modern tenant farmer. A fact of much importance in connexion with the Peasants' Revolt, soon to take place, was that the average money rent of land per acre in Forncett in 1378 was $10 d$., while the labour rents for land, where they were still paid by villeins who had not commuted or run away, were, owing to the rise in the value of labour, worth two or three times this. We cannot wonder that the poor villeins were profoundly discontented.

On this manor, as on others, some of the villeins, in spite of the many disadvantages under which they lay, managed to accumulate some little wealth. In 1378 and in 1410 one bond tenant had two messuages and 78 acres of land; in I 441 another died seized of 5 messuages and 52 acres; some had a number of servants in their households, but the majority were very poor. There are several instances of bondmen fleeing from the manor; and the officers of the manor failed to catch them. This was common in other manors, and the ' withdrawal ' of villeins played a considerable part in the disappearance of serfdom and the break-up of the system. ${ }^{2}$ The following table shows the gradual disappearance of villeins in the Manor of Forncett :

In 1400 the servile families who had land numbered . . 16

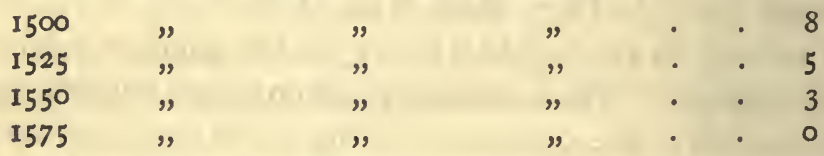

There is no event of greater importance in the agrarian history of England, or which has led to more important consequences, than the dissolution of this community in the cultivation of the land, which had been in use so long, and the

1 This had been done before, but was now much more frequent. Hasbach, op. cit. p. 17.

2 'After the Black Death the flight of villeins was extremely common.' -Page, op. cit. p. 40. 
establishment of the complete independence and separation of one property from another. ${ }^{1}$ As soon as the manorial system began to give way, and men to have a free hand, the substitution of large for small holdings set in with fresh vigour, for we have already seen that it had begun. It was one of the chief causes of the stagnation of agriculture in the Middle Ages that it lay under the heavy hand of feudalism, by which individualism was checked and hindered. Every one had his allotted position on the land, and it was hard to get out of it, though some exceptional men did so; as a rule there was no chance of striking out a new line for oneself. The villein was bound to the lord, and no lord would willingly surrender his services. There could be little improvement in farming when the custom of the manor and the collective ownership of the teams bound all to the same system of farming. ${ }^{2}$ In fact, agriculture under feudalism suffered from many of the evils of socialism.

But, though hard hit, the old system was to endure for many generations, and the modern triumvirate of landlord, tenant, and labourer was not completely established in England until the era of the first Reform Bill.

1 Nasse, Agricultural Community of the Middle Ages, p. I.

2 Cunningham, Industry and Commerce, i. I37. 


\section{CHAPTER IV}

HOW THE CLASSES CONNECTED WITH THE LAND LIVED IN THE MIDDLE AGES

THE castles of the great landowners have been so often described that there is no need to do this again. The popular idea of a baron of the Middle Ages is of a man who when he was not fighting was jousting or hunting. Such were, no doubt, his chief recreations; so fond was he of hunting, indeed, that his own broad lands were not enough, and he was a frequent trespasser on those of others; the records of the time are full of cases which show that poaching was quite a fashionable amusement among the upper classes. But among the barons were many men who, like their successors to-day, did their duty as landlords. Of one of the Lords of Berkeley in the fourteenth century, it was said he was 'sometyme in husbandry at home, sometyme at sport in the field, sometyme in the campe, sometyme in the Court and Council of State, with that promptness and celerity that his body might have bene believed to be ubiquitary'. Many of them were farmers on a very large scale, though they might not have so much time to devote to it as those excellent landlords the monks.

Thomas, Lord Berkeley, who held the Berkeley estates from 1326 to $136 \mathrm{I}$, farmed the demesnes of a quantity of manors, as was the custom, and kept thereon great flocks of sheep, ranging from 300 to 1,500 on each manor. ${ }^{1}$ The stock of the Bishop of Winchester, by an inquisition taken at his death in 1367 , amounted to 127 draught horses, 1,556 head of black cattle, and 12,104 sheep and lambs. Almost every

${ }^{1}$ Smyth, Lives of the Berkeleys, i. 302. No doubt the riches of the Berkeleys were considerably greater than those of many of the barons. 
manor had one or two pigeon houses, and the number of pigeons reared is astonishing; from one manor Lord Berkeley obtained 2, $15 \mathrm{I}$ pigeons in a single year. No one but the lord was allowed to keep them, and they were one of the chief grievances of the villeins, who saw their seed devoured by these pests without redress. Their dung, too, was one of the most valued manures. Lord Berkeley, like other landlords, went often in progress from one of his manors and farmhouses to another, making his stay at each of them for one or two nights, overseeing and directing the husbandry. The castle of the great noble consumed an enormous amount of food in the course of the year; from two manors on the Berkeley estate came to the 'standinghouse' of the lord in twelve months, I7,000 eggs, I,008 pigeons, gI capons, 192 hens, 288 ducks, 388 chickens, 194 pigs, 45 calves, 3 I 5 quarters of wheat, 304 quarters of oats; and from several other manors came the like or greater store, besides goats, sheep, oxen, butter, cheese, nuts, honey, \&c. ${ }^{1}$ Even the lavish hospitality of the lords, and the great number of their retainers, must have had some difficulty in disposing of these huge supplies.

The examining of their bailiff's accounts must have taken a considerable portion of the landlord's time, for those of each manor were kept most minutely, and set forth, among other items, 'in what sort he husbanded' the demesne farms, "what sorts of cattle he kept in them, and what kinds of graine he yearly sowed according to the quality and condition of the ground, and how those kinds of graine each second or third yeare were exchanged or brought from one manor to another as the vale corne into an upland soyle, and contrarily.' And we are told incidentally he 'set with hand, not sowed his beanes'. He was also accustomed to move his live stock from one manor to another, as they needed it.

1 Lives of the Berkeleys, i. 166. There is no reason to doubt Smyth, as he wrote with the original accounts before him. 
The accounts also stated what days' works were due from each tenant according to the season of the year, and at the end of each year there was a careful valuation of live and dead stock. 1

The difference between the smaller gentry and the more important yeomen ${ }^{2}$ who.farmed their own land must have been very slight. No doubt both of them were very rough and ignorant men, who knew a great deal about the cultivation of their land and very little about anything else. We may be sure that the ordinary house of both was generally of wood, as there is no stone in many parts of England, and bricks were not reintroduced till the fourteenth century and spread slowly. Even in Elizabeth's reign, Harrison ${ }^{3}$ tells us that 'the ancient houses of our gentry are yet for the most part of strong timber', and he even thinks that houses made of oak were luxurious, for in times past men had been contented with houses of willow, plum, and elm, but now nothing but oak was good enough; and he quaintly says that the men who lived in the willow houses were as tough as oak, and those who lived in the oak as soft as willow. There are very few mansions left of the time before Edward III, for being of timber they naturally decayed.

In a lease, dated $I I 5^{2}$, of a manor house belonging to S. Paul's Cathedral, ${ }^{*}$ is a description of a manor house which contained a hall 35 feet long, 30 feet broad, and 22 feet high; that is, I I feet to the tie beam and II feet from that to the ridge board; showing that the roof was open and that there were no upper rooms. There was a chamber between the hall and the thalamus or inner room which was $I_{2}$ feet long,

1 Lives of the Berkeleys, i. 156.

2 The yeoman is said to have made his appearance in the fifteenth century, but the small freeholders of the manor before that date were to all intents and purposes yeomen. No doubt, as trade grew in the fourteenth and fifteenth centuries successful tradesmen bought small freeholds in the country and swelled the numbers of yeomen.

3 Harrison, Description of Britain, F. J. Furnivall edn., p. 337.

4 Domesday of S. Paul, Camden Society, p. 129. 
I 7 feet broad, and 17 feet high, the roof being open as in the hall; and the thalamus was 22 feet long, 16 feet broad, and I 8 feet high. About the same date the Manor house of Thorp was larger, and contained a hall, a chamber, tresantia (apparently part of the hall or chamber separated by a screen to form an antechamber), two private rooms, a kitchen, brew-house, malthouse, dairy, ox shed, and three small hen-houses.

The ordinary manor house of the Middle Ages contained three rooms at least, of mean aspect, the floor even of the hall, which was the principal eating and sleeping room, being of dirt; and when there was an upper room or solar added, which began to be done at the end of the twelfth century, ${ }^{1}$ access to it was often obtained by an outside staircase.

If the manor house belonged to the owner of many manors, it was sometimes inhabited by his bailiff.

The barns on the demesnes were often as important buildings as the manor houses; one at Wickham, belonging to the canons of S. Paul's ${ }^{2}$ in the twelfth century, was 55 feet long, I 3 feet high from the floor to the principal beam, and 10 $\frac{1}{2}$ feet more to the ridge board; the breadth between the pillars was I $9 \frac{1}{2}$ feet, and on each side it had a wing or aisle $6 \frac{1}{2}$ feet wide and $6 \frac{1}{2}$ feet high. The amount of corn in the barn was often scored on the door-posts. ${ }^{3}$ In the manor houses chimneys rarely existed, the fire being made in the middle of the hall. Even in the early seventeenth century in Cheshire there were no chimneys in the farmhouses, and there the oxen were kept under the same roof as the farmer and his family. ${ }^{4}$ When chimneys did come in they were not much thought of. 'Now we have chimneys our tenderlings complain of rheums, catarrhs, and poses (colds);' for the smoke not only hardened the timbers, but was said by Harrison to be an excellent medicine for man. Instead of glass there was much lattice, and that

1 Turner, Domestic Architecture, i. 59.

2 Domesday of S. Paul, p. 123.

3 Historical MSS. Commission Report, v. 444.

${ }^{4}$ Ormerod, History of Cheshire, i. 129. 
made either of wicker or fine rifts of oak in checkerwise, and horn was also used. Beds, of course, were a luxury, the owner of the manor, his guests, and retainers flung themselves down on the hall floor after supper and all slept together, though sometimes rough mattresses were brought in.

Furniture was rude and scanty. In II 50 the farm implements and household furniture on the Manor of 'Waleton' was valued and consisted of 4 carts, 3 baskets, a basket used in winnowing corn, a pair of millstones, to tubs, 4 barrels, 2 boilers of lead with stoves, 2 wooden bowls, 3 three-legged tables, 20 dishes or platters, 2 tablecloths worth $6 d$., 6 metal bowls, half a load of the invaluable salt, 2 axes, a table with trestles (the usual form of table), and 5 beehives made of rushes. ${ }^{1}$ These articles were handed down from one generation to another, and in a lease made 150 years afterwards of the same manor most of them reappear. The greater part of the furniture, until the fifteenth century, was most likely made by migratory workmen, who travelled from village to village; for except the rudest pieces it was beyond the village carpenter, and shops there were none.

It is not to be expected that when the master lived in this manner the lot of the labourer was a very good one. His home was miserably poor, generally of 'wattle and dab', sometimes wholly of mud and clay; many with only one room for all purposes. A bill is still in existence for a house, if it can be called one, built in 1306 for two labourers by Queen's College, Oxford, which cost 2os. in all, and was a mere hovel without floor, ceiling, or chimney. ${ }^{2}$ Their wretched houses appear to have been built on the bare earth, and unfloored. Perhaps as time went on a rude upper storey was added, the floor of which was made of rough poles or hurdles and was reached by a ladder. The furniture was miserably poor : a few pots and pans, cups and dishes, and some tools would exhaust

1 Doomsday of S. Paul, p. xcvii.

2 Denton, England in the Fifteenth Century. 
the list. ${ }^{1}$ The goods and chattels of a landless labourer in I 43 I consisted of a dish, an adze, a brass pot, 2 plates, 2 augers, an axe, a three-legged stool, and a barrel. ${ }^{2}$ Englishmen of all classes were hopelessly dirty in their habits; even till the sixteenth century they were noted above other countries for the profuseness of their diet and their unclean ways. Erasmus spoke of the floor of his house as inconceivably filthy. To save fuel, the labourer's family in the cold season all lay huddled in a heap on the floor, 'pleasantly and hot', as Barclay the poet tells us; and if he ever had a bed it was a bundle of fern or straw thrown down, with his cloak as a coverlet, though thus he was just as well off as his social superiors, for with them the loose cloak of the day was a common covering for the night. He was constantly exposed to disease, for sanitary precautions were ignored; at the entrance of his hovel was a huge heap of decaying refuse, poisoning air and water. Even in the sixteenth century a foreigner noticed that 'the peasants dwell in small huts and pile up their refuse out of doors in heaps so high that you cannot see their houses'.3 Diseased animals were constantly eaten, vegetables were few, and in the winter there was no fresh meat for any one, except game and rabbits and, for the well-to-do, fish, but we may doubt if the peasant got any but salt fish. The consequence was that leprosy and kindred ailments were common; and we do not wonder that plagues were frequent and slew the people like flies. The peasants' food consisted largely of corn. In the bailiff's accounts of the Manor of Woodstock in 1242 , six servants at Handborough received $4 \mathrm{I} \frac{1}{2}$ bushels of corn each, 2 ox herds at Combe

1 Eden, State of the Poor, i. 21.

2 See Cullum, History of Hazusted.

- Harrison, Description of Britain, Appendix ii, lxxxi. In some manors, however, there were careful regulations for the public health. According to the Durham Halmote Rolls, published by the Surtees Society, village officials watched over the water supply, prevented the fouling of streams; bye-laws were enacted as to the regulation of the common place for clothes washing, and the times for emptying and cleansing ponds and mill-dams. 
received the same, and 4 servants at Bladon had 36 bushels each. In 1274 at Bosham, and in 1288 at Stoughton in Sussex, the allowance was the same. ${ }^{1}$ The writer of the anonymous Treatise on Husbandry says that in his time, the thirteenth century, the average annual allowance of corn to a labourer was $3^{6}$ bushels. $^{2}$ Fish, too, seem to have formed a large portion of his diet; all classes ate enormous quantities of fish, before the Reformation, in Lent and on fast days, and the labourer was constantly given salt herrings as part of his pay. In I359; at Hawsted, the villeins when working were allowed 2 herrings a day, some milk, a loaf, and some drink. ${ }^{3}$ Eden ${ }^{4}$ says his food consisted of a few fish, principally herrings, a loaf of bread, and some beer; but we must certainly add pork, which was his stand-by then as now. ${ }^{5}$ In the fourteenth century, at all events, there were three kinds of bread in use-white bread, ration bread, and black bread; and it was no doubt the latter that the peasant ate. ${ }^{6}$ Clothing was dear and cloth coarse, the most valuable personal property consisting of clothing and metal vessels. Shirts were the subject of charitable gifts. ${ }^{7}$ By $37 \mathrm{Edw}$. III, c. I4, labourers were not to wear any manner of cloth but 'blanket and russet wool of $12 d$.' and girdles of linen. If they wore anything more extravagant it was forfeited to the king.

To the labourer of modern times the life of his forefathers would have seemed unutterably dull. No books, no newspapers, no change of scene by cheap excursions, no village school, no politics. The very cultivation of the soil by the old three-course system was monotonous. But there were bright spots in his existence: the village church not only afforded him the consolations of religion but also entertainments and

1 Ballard, Domesday, Antiquary Series, p. 209.

2 Walter of Henley, Royal Historical Society, p. 75.

3 Cullum, Harested, 1784 ed., p. 182.

4 State of the Poor, i. 15 .

- Thorold Rogers, History of Agriculture and Prices, i. 32.

- See Knights Hospitallers in England, Camden Society, Introduction.

7 Thorold Rogers, cp. cit. i. 66. 
society. Religion in the Middle Ages was a part of the people's daily life, and its influence permeated even their amusements. Miracles and mystery plays, played in the churches and churchyards, were a common feature in village life; as were the church ales or parish meetings held four or five times a year, where cakes and beer were purchased from the churchwarden and consumed for the good of the parish. Indeed, there can be no doubt that there was much more sociability than to-day, in the country at least. Labour was lightened by the co-operation of the common fields; common shepherds and herdsmen watched the sheep and cattle of the different tenants, ' a common mill ground the corn, a common oven baked the bread, a common smith worked at a common forge.' . His existence, moreover, was enlivened by a considerable number. of sports. A statute at the end of the fourteenth century ( 12 Ric. II, c. 6) says he was fond of playing at tennis (!), football, quoits, dice, casting the stone, and other games, which this statute forbad him, and enacted that he should use his bow and arrows on Sundays and holidays instead of such idle sport. This is a foretaste of the modern sentiment that seeks to wean him from watching football matches and take to miniature rifle clubs. He was also, like some of his successors, fond of poaching, though he appears to have been rash enough to indulge in it by day. I3 Ric. II, c. I3, says he was prone on holidays, when good Christian people be in church hearing divine service, to go hunting with greyhounds and other dogs, in the parks and warrens of the lord and of others, and sometimes these hunts were turned into conferences and conspiracies, 'for to rise and disobey their allegiance', such as preceded the Peasants' Revolt of $I_{3} 8 \mathrm{I}$; and accordingly no one who did not own lands worth 40s. a year was to keep a dog to hunt, or ferrets, or other 'engines': the first game law on the English statute book. 


\section{CHAPTER V}

THE BREAK-UP OF THE MANOR.-SPREAD OF LEASES.THE PEASANTS' REVOLT.-FURTHER ATTEMPTS TO REGULATE WAGES. - A HARVEST HOME.-BEGINNING OF THE CORN LAWS.-SOME SURREY MANORS

WE have seen that the landlords' profits were seriously diminished by the Black Death, and they cast about them for new ways of increasing their incomes. Arable land had been until now largely in excess of pasture, the cultivation of corn was the chief object of agriculture, bread forming a much larger proportion of men's diet than now. This began to change. Much of the land was laid down to grass, and there was a steady increase in sheep farming; thus commenced that revolution in farming which in the sixteenth century led Harrison to say that England was mainly a stock-raising country. The lords also let a considerable amount of their demesne land on leases for years. 'Then began the times to alter,' says Smyth of the Lord Berkeley of the end of the fourteenth century, 'and hee with them, and he began to tack other men's cattle on his pasture by the week, month, and quarter, and to sell his meadow grounds by the acre. And in the time of Henry IV still more and more was let, and in succeeding times. As for the days' works of the copyhold tenants, they also were turned into money.' 1 Such leases had been used long before this, but this is the date of their great increase. In the thirteenth century a lease of 2 acres of

1 Smyth, Lives of the Berkeleys, ii. 5. There is no doubt the lease system was growing in the thirteenth century. About 1240 the writ Quare ejecit infra terminum protected the person of a tenant for a term of years, who formerly had been regarded as having no more than a personal right enforceable by an action of covenant. Vinogradoff, Villeinage in England, p. 330 ; but leases for lives and not for years seem the rule at that date. 
arable land in Nowton, Suffolk, let the land at $6 d$. an acre per annum for a term of six years. ${ }^{1}$ It contains no clauses about cultivation; the landlord warrants the said 2 acres to the tenant, and the tenant agrees to give them up at the end of the term freely and peaceably. The deed was indented, sealed, and witnessed by several persons. The impoverished landlords also let much of their land on stock and land leases. The custom of stocking the tenants' land was a very ancient one : the lord had always found the oxen for the plough teams of the villeins. In the leases of the manors of S. Paul's in the twelfth century the tenant for life received stock both live and dead, which when he entered was carefully enumerated in the lease, and at the end of the tenancy he had to leave behind the same quantity. ${ }^{2}$ It was a common practice also, before the Black Death, for the lord to let out cows and sheep at so much per head per annum. ${ }^{3}$ The stock and land lease therefore was no novelty. In I4Io there is a lease of the demesne lands at Hawsted by which the landlord kept the manor house and its appurtenances in his own hands, the tenant apparently having the farm buildings, which he was to keep in repair. He was to receive at the beginning of the term 20 cows and one bull, worth 9s. each; 4 stotts, worth IOs. each; and 4 oxen, worth $13 s .4 d$. each; which, or their value in money, were to be delivered up at the end of the term. The tenant was also to leave at the end of the lease as many acres well ploughed, sown, and manured as he found at the beginning. Otherwise the landlord was not to interfere with the cultivation. If the rent or any part thereof was in arrear for a fortnight after the two fixed days for payment, the landlord might distrain; and if for a month, he might re-enter: and both parties bound themselves to forfeit the then huge sum of $£ \mathrm{IOO}$ upon the violation of any clause

1 Cullum, Harusted, p. 175.

2 See Domesday of S. Paul, Introduction.

3 Thorold Rogers, History of Agriculture and Prices, i. 25. 
of the lease. ${ }^{1}$ There is a lease ${ }^{2}$ of a subsequent date (the twentieth year of Henry VIII), but one which well illustrates the custom now so prevalent, granted by the Prior of the Monastery of Lathe in Somerset to William Pole of Combe, Edith his wife, and Thomas his son, for their lives. With the land went 360 wethers. For the land they paid 16 quarters of best wheat, 'purelye thressyd and wynowed,' 22 quarters of best barley, and were to carry 4 loads of wood and fatten one ox for the prior yearly; the ox to be fattened in stall with the best hay, the only way then known of fattening oxen. For the flock of wethers they paid $£ 6$ yearly. The tenants were bound to keep hedges, ditches, and gates in repair. Also they were bound by a 'writing obligatory' in the sum of $£ 100$ to deliver up the wether flock whole and sound, 'not rotten, banyd, ${ }^{3}$ nor otherwise diseased.' The consequence of the spread of leases was that the portion of the demesne lands which the lords farmed themselves dwindled greatly, or it was turned from arable into grass. Stock and land leases survived in some parts till the beginning of the eighteenth century, when it was still the custom for the landlord to stock the land and receive half the crop for rent. ${ }^{4}$ According to the Domesday of S.Paul, in the thirteenth century, a survey of eighteen manors containing 24,000 acres showed three-eighths of the land in demesne, the rest in the hands of the tenants. In 1359 the lord of the principal manor at Hawsted held in his own hand 572 acres of arable land, worth $4 d$. to $6 d$. an acre rent, and 50 acres of meadow, worth 2s. an acre. $^{5}$ He had also pasture for 24 cows, which was

1 Cullum, Hazusted, p. 195.

2 Cunningham, Industry and Commerce, i. 586.

3 Banyd, afflicted with sheep rot.

Eden, State of the Poor, i. 55.

- Cullum, Hawsted, p. 182. Another instance of the difference in value between arable and tillage. At the inquisition of the Manor of Great Tey in Essex, 1326, the jury found that 500 acres of arable land was worth $6 i$. an acre rent, 20 acres of meadow $3 s$. an acre, and 10 acres of pasture $1 s$. an acre. Archaeologia, xii. 30. 
considered worth $3^{6 s}$. a year, and for 12 horses and 12 oxen worth $48 s$. a year, with 40 acres of wood, estimated at Is. an acre. In 1387 , however, the arable land had decreased to 320 acres, but the stock had increased, and now numbered 4 cart horses, 6 stotts or smaller horses, Io exen, I bull, 26 cows, 6 heifers, 6 calves, 92 wethers, 20 hoggerells or twoyear-old sheep, I gander, 4 geese, 30 capons, 26 hens, and only one cock. The dairy of 26 cows was let out, according to the custom of the time, for $£ 8$ a year; and we are told that the oxen were fed on oats, and shod in the winter only.

But if the position of the lords was severely affected by the great pestilence that of the villeins was also. The villein himself was becoming a copyholder; in the thirteenth century the nature of his holding had been written on the court roll, before long he was given a copy of the roll, and by the fifteenth century he was a copyholder. ${ }^{1}$ There was, too, a new spirit abroad in this century of disorganization and reform, which stirred even the villeins with a desire for better conditions of life. These men, thus rising to a more assured position and animated by new. hopes, saw all round them hired labourers obtaining, in spite of the Statute of Labourers, double the amount of wages they had formerly received, while they were bound down to the same services as before. The advance in prices was further increased by the king's issuing in $135 \mathrm{I}$ an entirely new coinage, of the same fineness but of less weight than the old; so that the demands of the labourers after the Black Death were largely justified by the depreciation in the currency. ${ }^{2}$ There had also arisen at this time, owing to the increase in the wealth of the country, a new class of landlords who did not care for the old system ${ }^{3}$; and it is probably these men who are meant by the statute I Ric. II, c. 6, which complains that the villeins daily withdrew their services to their lords at the instigation of various

1 Medley, Constitutional History, p. 52.

2 Cunningham, $o p$. cit. i. 328, and 335-6.

${ }^{3}$ Domesday of S. Paul, p. Ivii. 
counsellors and abettors, who made it appear by 'colour of certain exemplifications made out of the Book of Domesday' that they were discharged from their services, and moreover gathered themselves in great routs and agreed to aid each other in resisting their lords, so that justices were appointed to check this evil. But there were other 'counsellors and abettors' of the Peasants' Revolt than the new landlords. One of its most interesting features to modern readers is its thorough organization. Travelling agents and agitators like John Ball were all over the country, money was subscribed and collected, and everything was ripe for the great rising of $138 \mathrm{r}$, which was brought to a head by the bad grading of the poll tax of King Richard. It has been said that the chief grievance of the villeins was that the lords of manors were attempting to reimpose commuted services, but judging by the petition to the King when he met them at Mile-end there can be no doubt that the chief grievance was the continuance of existing services. 'We will', said they, 'that ye make us free for ever, and that we be called no more bond, or so reputed.' Also, as Walsingham says, ${ }^{1}$ they were careful to destroy the rolls and ancient records whereby their services were fixed, and to put to death persons learned in the law.

As every one knows, the revolt was a failure; and whether it ultimately helped much to extinguish serfdom is doubtful. It probably, like the pestilence, accelerated a movement which had been for some time in progress and was inevitable. There is ample evidence to prove that there was a very general continuance of predial services after the revolt, though they went on rapidly decreasing. One of the chief methods adopted by the villeins to gain their freedom was desertion, and so common did this become that apparently the mere threat of desertion enabled the villein to obtain almost any

${ }^{1}$ Hist. Angl., Rolls Series, i. 455. The other political and social causes of the revolt do not concern us here. The attempt to minimize its agrarian importance is strange in the light of the words and acts above mentioned. 
concession from his lord, who was afraid lest his land should be utterly deserted. The result was that by the middle of the fifteenth century the abolition of labour services was approaching completion. ${ }^{1}$ It lingered on, and Fitzherbert lamented in Elizabeth's reign the continuance of villeinage as a disgrace to England; but it had then nearly disappeared, and was unheard of after the reign of James I. ${ }^{2}$

Seven years after the Peasants' Revolt another attempt was made to regulate agricultural wages by the statute I2 Ric. II, c. 4, which stated that 'the hires of the said servants and labourers have not been put on certainty before this time', though we have seen that the Act of I $35 \mathrm{I}$ tried to settle wages. In the preamble it is said that the statute was enacted because labourers 'have refused for a long season to work without outrageous and excessive hire', and owing to the scarcity of labourers 'husbands' could not pay their rents, a sentence which shows the general use of money rents.

The wages were as follows, apparently with food:-

A bailiff annually, and clothing once a year . $\quad 134$

A master hind, without clothing . . . . . 100

A carter,

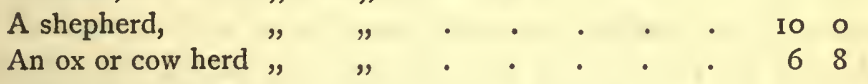

Swine herd or female labourer, without clothing . . 60

A plough driver, without clothing . . . . 70

The farm servants' food would be worth considerably more than the actual cash he received; a quarter of wheat, barley, and rye mixed every nine weeks was no unusual allowance, which at $4 s$. $4 d$. would be worth about $25 s$. a year. $\mathrm{He}$ would also have his harvest allowance, though the statute above forbids any perquisites, worth about 3 s., and sometimes it was accompanied by the gift of a pig, some beer, or some

1 Page, op. cit. p. 77.

2 Cunningham, Industry and Commerce, i. 402, 534 ; Transactions of the Royal Historical Society, New Series, xvii. 235. Fitzherbert probably referred more to villein status, which continued longer than villein tenure. 
herrings. ${ }^{1}$ His wife also, at a time when women did the same work as the men, could earn $1 d$. a day, and his boy perhaps $\frac{1}{2} d$. If his wages were wholly paid in money, we may say that in the last half of the fourteenth century the ordinary labourer earned $3 d$. a day, so that as corn and pork, his chief food, had not risen at all, he was much better off than in the preceding 100 years.

Cullum, in his invaluable History of Hawsted, gives us a picture of harvesting on the demesne lands in 1389 which shows an extraordinarily busy scene. There were 200 acres of all kinds of corn to be gathered in, and over 300 people took part; though apparently such a crowd was only collected for the two principal days of the harvest, and it must be remembered that the towns were emptied into the country at this important season. The number of people for one day comprised a carter, ploughman, head reaper, cook, baker, brewer, shepherd, daya (dairymaid); $22 \mathrm{I}$ hired reapers; 44 pitchers, stackers, and reapers (not hired, evidently villeins paying their rents by work); 22 other reapers, hired for goodwill (de amore); and 20 customary tenants. This small army of men consumed 22 bushels of wheat, 8 pennyworth of beer, and $4 \mathrm{I}$ bushels of malt, worth I $8 s .9 \frac{1}{2} d$.; meat to the value of $9 s$. I $1 \frac{1}{2} d_{0}$; fish and herrings, $5 s .1 d$. ; cheese, butter, milk, and eggs, 8 s. $3 \frac{1}{2} d_{\text {. }}$; oatmeal, $5 d_{\text {. }}$; salt, $3 d$.; pepper and saffron, Iod., the latter apparently introduced into England in the time of Edward III, and much used for cooking and medicine, but it gradually went out of fashion, and by the end of the eighteenth century was only cultivated in one or two counties, notably Essex where Saffron Walden recalls its use ; candles, $6 d$; and 5 pairs of gloves $10 d .^{2}$

The presentation of gloves was a common custom in England; and these would be presented as a sign of good hus-

1 Thorold Rogers, History of Agriculture and Prices, i. 278, 288.

${ }^{2}$ Harrison, Description of Britain, p. 233, says the produce of an acre of saffron was usually worth $£ 20$. 
bandry, as in the case of the rural bridegroom in the account of Queen Elizabeth's visit to Kenilworth who wore gloves to show he was a good farmer. Tusser bids the farmer give gloves to his reapers. The custom was still observed at Hawsted in 1784 , and in Eden's time, I797, the bursars of New College, Oxford, presented each of their tenants with two pairs, which the recipients displayed on the following Sunday at church by conspicuously hanging their hands over the pew to show their neighbours they had paid their rent. In this account of the Hawsted harvest the large number of hired men and the few customary tenants is noteworthy as a sign of the times, for before the Black Death the harvest work on the demesne was the special work of the latter.

In the fourteenth century the long series of corn laws was commenced which was to agitate Englishmen for centuries, and after an apparently final settlement in 1846 to reappear in our day. ${ }^{1}$ It was the policy of Edward III to make food plentiful and cheap for the whole nation, without special regard to the agricultural interest : and by $34 \mathrm{Edw}$. III, c. 20, the export of corn to any foreign part except Calais and Gascony, then British possessions, or to certain places which the king might permit, was forbidden. Richard II, however, reversed this policy in answer to the complaints of agriculturists whose rents were falling, ${ }^{2}$ and endeavoured to encourage the farmer and especially the corn-grower; for he saw the landlords turning their attention to sheep instead of corn, owing to the high price of labour. Accordingly, to give the corngrowers a wider market, he allowed his subjects by the statute I7 Ric. II, c. 7, to carry corn, on paying the duties due, to

${ }^{1}$ Exportation of corn is mentioned in 1181 , when a fine was paid to the king for licence to ship corn from Norfolk and Suffolk to Norway.-

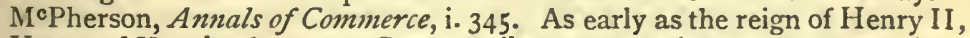
Henry of Huntingdon says, German silver came to buy our most precious wool, our milk (no doubt converted into butter and cheese), and our innumerable cattle.-Rolls Series, p. 5. In 1400, the Chronicle of London says the country was saved from dearth by the importation of rye from Prussia.

${ }^{2}$ Hasbach, op. cit. p. 32. 
what parts they pleased, except to his enemies, subject however to an order of the Council; and owing to the interference of the Council the law probably became a dead letter, at all events we find it confirmed and amended by $4 \mathrm{Hen}$. VI, c. 5 .

The prohibition of export must have been a serious blow to those counties near the sea, for it was much easier to send corn by ship to foreign parts than over the bad roads of England to some distant market. ${ }^{1}$ Indeed, judging by the great and frequent discrepancy of prices in different places at the same date, the dispatch of corn from one inland locality to another was not very frequent. Richard also attempted to stop the movement, which had even then set in, of the countrymen to the growing towns, forbidding by $I_{2}$ Ric. II, c. 5 , those who had served in agriculture until I 2 years of age to be apprenticed in the towns, but to 'abide in husbandry'.

One of the most unjust customs of the Middle Ages was that which bade the tenants of manors, except those who held the jus faldae, fold their sheep on the land of the lord, thus losing both the manure and the valuable treading. ${ }^{2}$ However, sometimes, as in Surrey, the sheepfold was in a fixed place and the manure from it was from time to time taken out and spread on the land. ${ }^{3}$

In the same district horses had been hitherto used for farm work, as it was considered worthy of note that oxen were beginning to be added to the horse teams. The milk of two good cows in twenty-four weeks was considered able to make a wey of cheese, and in addition half a gallon of butter a week; and the milk of 20 ewes was equal to that of 3 cows.

On the Manor of Flaunchford, near Reigate, the demesne land amounted to $5^{6}$ acres of arable and two meadows, but

1 Lord Berkeley, about 1360 , had a ship of his own for exporting wool and corn and bringing back foreign wine and wares.-Smyth, Lives of the Berkeleys, i. 365 .

2 Nasse, Agricultural Community of the Middle Ages, p. 66.

$s$ Customs in some Surrey manors in the time of Richard II, Archaeologia, xviii. 281. 
there must have been the usual pasture in addition to keep the following head of stock: $I_{3}$ cows, who in the winter were fed from the racks in the yard; 4 calves, bought at Is. each; 12 oxen for ploughing, whose food was oats and haya very large number for $5^{6}$ acres of arable, and they were probably used on another manor; I stott, used for harrowing ; a goat, and a sow.

In 1382 the total receipts of this manor were . $\quad \begin{array}{llll}f_{0} & s . & d \\ 8 & 1 & 9 \frac{1}{2}\end{array}$

The total expenses

Profit \begin{tabular}{rrr}
7 & 0 & 5 \\
\hline 11 & 1 & $4 \frac{1}{2}$ \\
\hline
\end{tabular}

Among the receipts were :-

For the lord's plough, let to farmers (perhaps this accounts for the large team of oxen kept) .

14 bushels of apples

68

12

168

100

Among the payments:-

For keeping plough in repair, and the wages of a blacksmith, one year by agreement . . Making a new plough from the lord's timber . Mowing 2 acres of meadow .

Making and carrying hay of ditto, with help of lord's servants

Threshing wheat, peas, and tares, per quarter

68

6

I 0

$\begin{array}{lllll}\text { "o oats, per quarter. } & \cdot & \cdot & \cdot & \mathbf{I}^{\frac{1}{2}} \\ \text { Winnowing } 3 \text { quarters of corn } & \cdot & \cdot & \cdot & \mathbf{1} \\ \text { Cutting and binding wheat and oats, per acre } & . & 6\end{array}$

On the Manor of Dorking the harvest lasted five weeks as a rule; the fore feet only of oxen used for ploughing, and of heifers used for harrowing, were shod. For washing and shearing sheep rod. a hundred was the price; ploughing for winter corn cost $6 d$. an acre, and harrowing $\frac{1}{2} d$. $30 \frac{1}{2}$ acres of barley produced $41 \frac{1}{2}$ quarters ; 28 acres of oats produced $3^{8 \frac{1}{2}}$ quarters; 13 cows were let for the season at 5 s. each. In the same reign, at Merstham, the demesne lands of $166 \frac{1}{2}$ acres were let on lease with all the live and dead stock, which was valued at $£ 22$ 9s. $3^{d}$., and the rent was $£ 3^{6}$ or about 4 s. $4 d$. an acre, an enormous price even including the stock. 


\title{
CHAPTER VI
}

\author{
I 400 - I 540
}

THE SO-CALLED 'GOLDEN AGE OF THE LABOURER' IN A PERIOD OF GENERAL DISTRESS

In this period the average prices of grain remained almost unchanged until the last three decades, when they began slowly and steadily to creep up, this advance being helped to some extent by defective harvests. In 1527 , according to Holinshed it rained from April 12 to June 3 every day or night ; in May thirty hours without ceasing; and the floods did much damage to the corn. In 1528 incessant deluges of rain prevented the corn being sown in the spring, and grain had to be imported from Germany. The price of wheat was a trifle higher than in the period 1259-1400; barley, oats, and beans lower; rye higher. ${ }^{1}$ Oxen and cows were dearer, horses about the same, sheep a little higher, pigs the same, poultry and eggs dearer, wool the same, cheese and butter dearer. The price of wheat was sometimes subject to astonishing fluctuations: in 1439 it varied from $8 s$. to $26 s$. $8 d$. ; in 1440 from $4 s$. $2 d$. to $25 s$. The rent of land continued the same, arable averaging $6 d$. an acre $^{2}$ though this was partly due to the fact that rents, although now generally paid in money, were still fixed and customary; for the purchase value of land had now risen to twenty years instead of twelve. ${ }^{3}$ The art of farming hardly made any progress, and the produce of the land was con-

1 See table at end of volume. The shrinkage of prices which occurred in the fifteenth century was due to the scarcity of precious metals.

2 Thorold Rogers, History of Agriculture and Prices, iv. 128. The rent of arable land on Lord Derby's estate in Wirral in 1522 was a little under $6 \pi$. a statute acre; of meadow, about is. 6d.-Cheshire Sheaf (Ser. 3), iv. 23 .

3 Thorold Rogers, op. cit. iv. 3 . 
sequently about the same or a little better than in the preceding period. ${ }^{1}$

At the end of the fourteenth century the ordinary wheat crop at Hawsted was in favourable years about a quarter to the acre, but it was often not more than 6 bushels; and this was on demesne land, usually better tilled than non-demesne land. ${ }^{2}$ As for the labourer, it is well known that Thorold Rogers calls the fifteenth century his golden age, and seeing that his days' wages, if he 'found himself', were now $4 d$. and prices were hardly any higher all round than when he earned half the money in the thirteenth century, there is much to support his view. As to whether he was better off than the modern labourer it is somewhat difficult to determine; as far as wages went he certainly was, for his $4 d$. a day was equal to about $4 s$. now; it is true that on the innumerable holidays of the Church he sometimes did not work, ${ }^{3}$ but no doubt he then busied himself on his bit of common. But so many factors enter into the question of the general material comfort of the labourer in different ages that it is almost impossible to come to a satisfactory conclusion. Denton paints a very gloomy picture of him at this time $;^{4}$ so does Mr. Jessop, who says, the agricultural labourers of the fifteenth century were, compared with those of to-day, 'more wretched in their poverty, incomparably less prosperous in their prosperity; worse clad, worse fed, worse housed, worse taught, worse governed; they were sufferers from loathsome diseases, of which their descendants know nothing; the very beasts of the field were dwarfed and stunted; the disregard of

1 Thorold Rogers, $o p$. cit. iv. 39 .

${ }^{2}$ Cullum, Hawsted, p. 187. The amount of seed for the various crops was, wheat 2 bushels per acre, barley 4 , oats $2 \frac{1}{2}$.

${ }_{3}$ By 4 Hen. IV, c. I 4, labourers were to receive no hire for holy days, or on the eves of feasts for more than half a day; but the statute was largely disregarded.

See England in the Fifteenth Century, p. 105: 'The undrained neglected soil, the shallow stagnant waters which lay on the surface of the ground, the unhealthy homes of all classes, insufficient and unwholesome food, the abundance of stale fish eaten, and the scanty supply of vegetables predisposed rural and town population to disease.' 
human life was so callous that we can hardly conceive it ; there was everything to harden, nothing to soften; everywhere oppression, greed, and fierceness.' 1 The truth seems to be that the fifteenth century was a period of general distress; the progress of the twelfth and thirteenth centuries was checked by the Black Death and the Hundred Years' War, and it is no wonder that the fifteenth, aggravated by the Wars of the Roses, was a period of ruin and decay in town and country. Many parishes were exempted from the payment of taxes, because 'there are no sheep or lambs at present', or because the lands were untilled, or murrain had destroyed the stock, or the lands were waste. ${ }^{2}$ Pestilence was as frequent as in the preceding century; in 1477 the plague swept off in four months three times as many people as had perished during the Wars of the Roses, and as the bulk of the working classes were agricultural labourers it is no wonder that wages went up. We have a convincing proof of the devastation wrought by the wars and plagues of the time in the words of a statute of $1421,{ }^{3}$ which says that at the making of an Act of 1340 there were sufficient of proper men in each county to execute every office, 'but that owing to pestilence and wars there are not now a sufficiency of responsible persons to act as sheriffs, coroners, and escheators.' It is a fact not sufficiently admitted that the depopulation of the countryside at the end of the fifteenth and beginning of the sixteenth centuries was largely due to war and pestilence, rather than enclosure. The roads, too, bad as they were, grew worse with the decrease in the villein class, who had repaired them under the supervision of the manorial courts; while the impoverishment of the monasteries, very marked some time before their dissolution, prevented them from giving their accustomed care and attention to them. The records of the time are full of riots, which show that the labourer was not contented with his lot in

1 Nineteenth Century, February, 1884.

2 Denton, op. cit. 21 ; Sussex Archaeological Collections, i. 63.

39 Hen. V, c. 5. 
spite of his high wages; though we must not attach too much importance to disorder in the Middle Ages, for it prevailed to an almost incredible extent among all classes, the gentry laying wait for those against whom they had a grudge with large gangs of ruffian retainers, who fell with savage cowardice on their victims. On the bright side of the picture must be put the development of the cloth trade, which helped those who kept sheep, though until ${ } 540$ there was apparently no increase in the price of wool. ${ }^{1}$

A large quantity of the wool now grown in England was manufactured into cloth at home instead of being exported, with the result that the customs in wool at Calais had decreased from $£ 68,000$ in the time of Edward III to $£ 12,000$ in $1448 .^{2}$ It was fortunate for the fifteenth century that the seasons as a rule were very good, the years $1421-7$ and $1439-45$ being very abundant, and $1454-5$ particularly so ; wheat in that year averaging $3 s .10 \frac{1}{4} d$., the lowest price of the century ; barley, $2 s .9 \frac{1}{2} d$.; oats, Is. $8 \frac{1}{2} d$. ; peas, $2 s .3 \frac{1}{4} d .^{3}$

In $146_{3}$ it was nearly as cheap, and remained at a low figure till the end of the century. There were some exceptions to the bountiful crops: in $143^{8}$ it rained long and heavily in the summer, and the sun rarely showed itself, so that the scarcity was universal, and the Lord Mayor of London sent to Prussia and brought to London certain ships laden with rye, which eased and did much good to the people, for corn was so scarce in some places that the poor made bread of fern roots. Corn also came that year from Denmark. ${ }^{4}$

Important alterations were made in the corn laws. The statute 15 Hen. VI, c. 2 says that by former laws no one could export grain without the king's licence, so that farmers, ' and other men which use manurement of their land,' ${ }^{5}$ were obliged

1 Thorold Rogers, History of Agriculture and Prices, i. 366, iv. 328.

2 Cunningham, Industry and Commerce, i. 434.

${ }^{3}$ Thorold Rogers, op. cit. iv. 284.

- MePherson, Annals of Commerce, i. 655.

3 'Manuring' is here used in the sense of managing or farming. 
to sell their corn at low prices to the detriment of the whole kingdom: a typical example of the political economy of the time, which considered the prosperity of agriculture indispensable to the welfare of the country, even if the consumer suffered. Accordingly, it was enacted that wheat could be exported without a licence when it was under $6 s .8 d$. a quarter, except to the king's enemies. On imports of corn there had been no restriction until 1463 , when 3 Edw. IV, c. 2 forbade the import of corn when under $6 s .8 d$ : a statute due partly to the fear that the increase of pasture was a danger to tillage land and the national food supply, and partly to the fact that the landed interest had become by now fully awake to the importance of protecting themselves by promoting the gains of the farmer. ${ }^{1}$ It may be doubted, however, if much wheat was imported except in emergencies at this time, for many countries forbade export. These two statutes were practically unaltered till $157 x,{ }^{2}$ and by that of ${ }^{4} 463$ was initiated the policy which held the field for nearly 400 years.

Thorold Rogers denounces the landlords for legislating with the object of keeping up rents, but, as Mr. Cunningham has pointed out, this ignores the fact that the land was the great fund of national wealth from which taxation was paid; if rents therefore rose it was a gain to the whole country, since the fund from which the revenue was drawn was increased. ${ }^{3}$

In spite of the high wages of agricultural labourers, the movement towards the towns noticed by Richard II continued. The statute $7 \mathrm{Hen}$. IV, c. I 7, asserts that there is a great scarcity of labourers in husbandry and that gentlemen are much impoverished by the rate of wages; the cause of the scarcity lying in the fact that many people were becoming weavers, ${ }^{4}$ and

1 Cunningham, Industry and Commerce, i. 448.

${ }^{2} \mathrm{M}^{\mathrm{C}} \mathrm{Culloch}$, Commercial Dictionary (1852), p. 412. In I 449 Parliament had decided that all foreign merchants importing corn should spend the money so obtained on English goods to prevent it leaving the country. -M Pherson, Annals of Commerce, i. 655.

3 Cunningham, Industry and Commerce, i. I91.

- Much of the weaving, however, was done in rural districts. 
it therefore re-enacted 12 Ric. II, c. 5, which ordained that no one who had been a servant in husbandry until 12 years old should be bound apprentice, and further enacted that no person with less than 2os, a year in land should be able to apprentice his son. Like many other statutes of the time this seems to have been inoperative, for we find $23 \mathrm{Hen}$. VI, c. I2 (1444), enacting that if a servant in husbandry purposed leaving his master he was to give him warning, and was obliged either to engage with a new one or continue with the old. It also regulated the wages anew, those fixed showing a substantial increase since the statute of 1388 . By the year:-

A bailiff was to have $£ \mathrm{I} 3 s .4 d$., and $5 s$. worth of clothes.

A chief hind, carter, or shepherd, $£ \mathrm{I}$, and $4 s$. worth of clothes.

A common servant in husbandry, $15 s$, and $3 s .4 d$. worth of clothes.

A woman servant, Ios., and $4 s$. worth of clothes.

All with meat and drink.

By the day, in harvest, wages were to be:-

A mower, with meat and drink, $4 d$; without, $6 d$.

A reaper or carter, with meat and drink, $3 d$; without, $5 d$.

A woman or labourer, with meat and drink, $2 d$.; without, $4 d$.

In the next reign the labourer's dress was again regulated for him, and he was forbidden to wear any cloth exceeding $2 s$. a yard in price, nor any 'close hosen', apparently tight long stockings, nor any hosen at all which cost more than $14 d .{ }^{1}$ Yeomen and those below them were forbidden to wear any bolsters or stuff of wool, cotton wadding, or other stuff in their doublets, but only lining; and somewhat gratuitously it was ordered that no one under the degree of a gentleman should wear pikes to his shoes.

In I 455 England's Thirty Years' War, the War of the Roses, began, and agriculture received another set back. The view that the war was a mere faction fight between nobles and their retainers, while the rest of the country went about their

${ }^{1}$ See 3 Edw. IV, c. 5 ; Rot. Parl.v. 105; 22 Edw. IV, c. I. 
business, is somewhat exaggerated. No doubt, the mass of Englishmen, as in the civil war of the seventeenth century, preferred to 'sit still', as Clarendon said, but the business of many must have been very much upset. The various armies were compelled to obtain their supplies from the country, and with the lawless habits of the times plundered friend and foe alike, as Cavalier and Roundhead did afterwards; and many a farmer must have seen all his stock driven off and his grain seized to feed the combatants. For instance, it was said before the battle called Easter Day Field that all the tenants of Abbot's Ripton in Huntingdonshire were copyholders of the Abbot of Ramsey, and the northern army lay there so long that they impoverished the country and the tenants had to give up their copyholds through poverty. ${ }^{1}$ The loss of life, too, must have told heavily on a country already suffering from frequent pestilence. It is calculated that about one-tenth of the whole population of the country were killed in battle or died of wounds and disease during the war; and as these must have been nearly all men in the prime of life, it is difficult to understand how the effect on the labour market was not more marked. The enclosing of land for pasture farms, which we shall next have to consider, was probably in many cases an absolute necessity, for the number of men left to till the soil must have been seriously diminished.

1 Cunningham, op. cit. i. 456. 


\section{CHAPTER VII}

\section{ENCLOSURE}

WE have now reached a time when the enclosure question was becoming of paramount importance, ${ }^{1}$ and began to cause constant anxiety to legislators, while the writers of the day are full of it. Enclosure was of four kinds:

I. Enclosing the common arable fields for grazing, generally in large tracts.

2. Enclosing the same by dividing them into smaller fields, generally of arable.

3. Enclosing the common pasture, for grazing or tillage.

4. Enclosing the common meadows or mowing grounds.

It is the first mainly, and to a less degree the third of these, which were so frequent a source of complaint in the fifteenth and sixteenth centuries; for the first, besides displacing the small holder, threw out of employment a large number of people who had hitherto gained their livelihood by the various work connected with tillage, and the third deprived a large number of their common rights.

The first Enclosure Act was the Statute of Merton, passed in 1235, 20 Henry III, c. 4, which permitted lords of manors to add to their demesnes such parts of the waste pasture and woods as were beyond the needs of the tenants. There is evidence, however, that enclosure, probably of waste land, was going on before this statute, as the charter of John, by which all Devonshire except Dartmoor and Exmoor was deforested, expressly forbids the making of hedges, a proof of enclosure, in those two forests. ${ }^{2}$ We may be sure that the

1 Much the same tendencies were at work in other countries, especially in Germany.

'Slater, English Peasantry and Enclosure, 248. 
needs of the tenants were by an arbitrary lord estimated at a very low figure. At the same time many proceeded in due legal form. Thomas, Lord Berkeley, about the period of the Act reduced great quantities of ground into enclosures by procuring many releases of common land from frecholders. ${ }^{1}$ His successor, Lord Maurice, was not so observant of legality. He had a wood wherein many of his tenants and freeholders had right of pasture. He wished to make this into a park, and treated with them for that purpose; but things not going smoothly, he made the wood into a park without their leave, and then treated with his tenants, most of whom perforce fell in with his highhanded plan; those who did not 'fell after upon his sonne with suits, to their small comfort and less gaines.' 2 Sometimes the rich made the law aid their covetousness, as did Roger Mortimer the paramour of the 'She Wolf of France'. Some men had common of pasture in King's Norton Wood, Worcestershire, who, when Mortimer enclosed part of their common land with a dike, filled the dike up, for they were deprived of their inheritance. Thereupon Mortimer brought an action of trespass against them ' by means of jurors dwelling far from the said land ', who were put on the panel by his steward, who was also sheriff of the county, and the commoners were convicted and cast in damages of $£ 300$, not daring to appear at the time for fear of assault, or even death. ${ }^{3} \quad$ Neither dared they say a word about the matter till Mortimer was dead, when it is satisfactory to learn that Edward III gave them all their money back save 20 marks. We are told that Lord Maurice Berkeley consolidated much of his demesne lands, throwing together the scattered strips and exchanging those that lay far apart from the manor houses for those that lay near; trying evidently to get the home farms into a ring fence as we should term it. ${ }^{4}$. In this policy he

1 Smyth, Lives of the Berkeleys, i. II 3.

Cal. Pat. Rolls, 1331, p. I27.

- Lives of the Berkeleys, i. I4I.

2 Ibid. i. I4I. 
was followed by his successor Thomas the Second, who during his ownership of the estate from 1281 to $I 320$, to the great profit of his tenants and himself, encouraged them to make exchanges, so as to make their lands lie in convenient parcels instead of scattered strips, by which he raised the rent of an acre from $4 d$. and $6 d$. to $1 s .6 d .^{1}$ There is a deed of enclosure made in the year 1250 , preserved, by which the free men of North Dichton 'appropriated and divided between them and so kept for ever in fee all that place called Sywyneland, with the moor,' and they were to have licence to appropriate that place, which was common pasture (the boundaries of which are given), 'save, however, to the grantor William de Ros and his heirs' common of pasture in a portion thereof named by bounds, with entry and exit for beasts after the wheat is carried. The men of North Dichton were also to have all the wood called Rouhowthwicke, and to do what they liked with it. ${ }^{2}$ In return they gave the lord to marks of silver and a concession as regards a certain wood. It has been noticed that the Black Death, besides causing many of the landlords to let their demesnes, also made them turn much tillage into grass to save labour, which had grown so dear. We have also seen that the statutes regulating wages were of little effect, and they went on rising, so that more land was laid down to grass. The landowners may be said to have given up ordinary farming and turned to sheep raising.

English wool could always find a ready sale, although Spanish sheep farming had developed greatly ; and the profitable trade of growing wool attracted the new capitalist class who had sprung up, so that they often invested their recently made fortunes in it, buying up many of the great estates that were scattered during the war. ${ }^{3}$

The increase of sheep farming was assisted by the fact that

1 Lives of the Berkeleys, i. 160.

2 Historical MSS. Commission, 6th Report, p. 359.

${ }^{3}$ Cunningham, Industry and Commerce, i. 379. 
the domestic system of the manufacture of wool, which supplanted the guild system, led, owing to its rapid and successful growth, to a constant and increasing demand for wool. At the same time this development of the cloth industry helped to alleviate the evils it had itself caused by giving employment to many whom the agricultural changes wholly or partially deprived of work. 'It is important to remember, that where peasant proprietorship and small farming did maintain their ground it was largely due to the domestic industries which supplemented the profits of agriculture.' 1

Much of the land laid down to grass was demesne land, but many of the common arable fields were enclosed and laid down. John Ross of Warwick about 1460 compares the country as he knew it with the picture presented by the Hundred Rolls in Edward I's time, showing how many villages had been depopulated; and he mentions the inconvenience to travellers in having to get down frequently to open the gates of enclosed fields. ${ }^{2}$

Enclosure was really a sure sign of agricultural progress; nearly all the agricultural writers from Fitzherbert onwards are agreed that enclosed land produced much more than uninclosed. Fitzherbert, in the first quarter of the sixteenth century, said an acre of land rented for $6 d$. uninclosed was worth $8 d$. when enclosed. Gabriel Plattes, in the seventeenth century, said an acre enclosed was worth four in common. In fact, the history of enclosures is part of the history of the great revolution in agriculture by which the manorial system was converted into the modern system as we know it to-day of several ownership and the triumvirate of landlord, tenant farmer, and labourer. No one could have objected to the enclosure of waste; it was that of the common arable fields and of the common pasture that excited the indignation of contemporaries. They saw many of the small holders displaced and the country-side

${ }^{1}$ Ashley, English Woollen Industry, pp. 80-I. Broadly speaking, there are four stages in the development of industry-the family system, the guild system, the domestic system, and the factory system.

${ }^{2}$ Hist. Reg. Angl. p. I 20. 
depopulated; many of the labourers were also thrown out of employment, for there was no need in enclosed fields of the swineherd and shepherd and oxherd who had tended the common flocks of the villagers in the old unfenced fields. But much of the opposition was founded on ignorance and / hatred of change ; England had been for ages mainly a corngrowing land, and, many thought, ought to remain so. As a matter of fact, what much of the arable land wanted was laying down to grass; it was worn out and needed a rest. The common field system was wasteful; the land, for instance, could never be properly ploughed, for the long narrow strips could not be cross-ploughed, and much of it must have suffered grievously from want of manure at a time when hardly any stock was kept in the winter to make manure. The beneficial effect of the rest is shown by the fact that at the end of the sixteenth century, when some of the land came to be broken up, the produce per acre of wheat had gone up largely. ${ }^{1}$ Marling and liming the land, too, which had been the salvation of much of it for centuries, had gone out partly because of insecurity of tenure, partly because in the unsettled state of England men knew not if they could reap any benefit therefrom; and partly because, says Fitzherbert, men were lazier than their fathers. There can be no doubt that enclosures were often accompanied 1 with great hardships and injustice. Dugdale, speaking of Stretton in Warwickshire: ${ }^{2}$ says that in Henry VII's time Thomas Twyford, having begun the depopulation thereof, decaying four messuages and three cottages whereunto 160 acres of 'errable' land belonged, sold it to Henry Smith; which Henry, following that example, enclosed 640 acres of land more, whereby twelve messuages and four cottages fell to ruins and eighty persons there inhabiting, being employed about tillage and husbandry, were constrained to depart thence and live miserably. By means whereof the church grew to

1 Gisborne, Agricultural Essays, pp. 186-9.

2 Antiquities of Warwickshire, 2nd ed., p. $5 \mathrm{I}$. 
such ruin that it was of no other use than for the shelter of cattle. A sad picture, and true of many districts, but much of the depopulation ascribed to enclosures was due to the devastation of the Civil Wars.

In spite of these enclosures, which began to change the England of open fields into the country we know of hedgerows and winding roads, great part of the land was in a wild and uncultivated state of fen, heath, and wood, the latter sometimes growing right up to the walls of the towns. ${ }^{1}$ An unbroken series of woods and fens stretched right across England from Lincoln to the Mersey, and northwards from the Mersey to the Solway and the Tweed; Warwickshire, Northamptonshire, and Leicestershire were largely covered by forests, and Sherwood Forest extended over nearly the whole of Notts. Cannock Chase was covered with oaks, and in the forest of Needwood in Camden's time the neighbouring gentry eagerly pursued the cheerful sport of hunting. The great forest of Andredesweald, though much diminished, still covered a large part of Sussex, and the Chiltern district in Bucks and Oxfordshire was thick with woods which hid many a robber. The great fen in the east covered 300,000 acres of land in six counties, in spite of various efforts to reclaim the land, and was to remain in a state of marsh and shallow water till the seventeenth century.

North and west of the great fen was Hatfield Chase, 180,000 acres mostly swamp and bog, with here and there a strip of cultivated land, much of which had been tilled and neglected; a great part too of Yorkshire was swamp, heath, and forest, and of Lancashire marshes and mosses, some of which were not drained till recent times. The best corn-growing counties were those lying immediately to the north of London, stretching from Suffolk to Gloucestershire, and including the southern portions of Staffordshire and Leicestershire; Essex was a

1 Denton, England in the Fifteenth Century, p. 135. 
great cheese county; Hants, Cambridgeshire, Northamptonshire, and Bedfordshire were famous for malt, and Leicestershire for peas and beans. The population of England in 1485 was probably from two to two and a half millions. At the time of Domesday it was under two millions, and from that date increased perhaps to nearly four millions at the time of the Black Death in $134^{8-9}$, which swept away from one-third to one-half of the people, and repeated wars and pestilences seem to have kept it from increasing until Tudor times. Of the whole population no fewer than eleven-twelfths were employed in agriculture. ${ }^{1}$

It was sought to remedy enclosure and depopulation by legislation, and the statute of $4 \mathrm{Hen}$. VII, c. I9, was passed, which stated in its preamble that where in some towns (meaning townships or villages) 200 persons used to be occupied and lived by their lawful labours, now there are occupied only two or three herdsmen, so that the residue fall into idleness, and husbandry is greatly decayed, churches destroyed, the bodies there buried not prayed for, the parsons and curates wronged, and the defence of this land enfeebled and impaired; the latter point being wisely deemed one of the most serious defects in the new system of farming. Indeed, the encouragement of tillage was largely prompted by the desire to see the people fed on good home-grown corn and made strong and healthy by rural labour for the defence of England. It therefore enacted that houses which within three years before had been let for farms with 20 acres of tillage land should be kept in that condition, under a penalty of forfeiting half the profits to the king or the lord of the fee. Soon after Henry VIII ascended the throne came another statute, $6 \mathrm{Hen}$. VIII, c. 5, that all townships, villages, \&c., decayed and turned from husbandry and tillage into pasture, shall by the owner be rebuilt and the land made mete for tillage within one year; and this

1 See Cunningham, Industry and Commerce, i. 331 ; Denton, England in the Fifteenth Century, p. 127. 
was repeated and made perpetual by a law of the next year. ${ }^{1}$

But legislation was in vain; the price of wool was now beginning to advance so that the attraction of sheep farming was irresistible, and laws, which asked landowners and farmers to turn from what was profitable to what was not, were little likely to be observed, especially as the administration of these laws was in the hands of those whose interest it was that they should not be observed.

Their ill success, however, did not deter the Parliament from fresh efforts. $25 \mathrm{Hen}$. VIII, c. I3, sets forth the condition of affairs in its preamble: as many persons have accumulated into few, great multitude of farms and great plenty of cattle, especially sheep, putting such land as they can get into pasture, and enhanced the old rents and raised the prices of corn, cattle, wool, and poultry almost double, 'by reason whereof a mervaylous multitude and nombre of the people of this realme be not able to provide drynke and clothes necessary for themselves, but be so discoraged with myserie and povertie that they fall dayly to thefte and robberye or pitifully dye for hunger and colde.' So greedy and covetous were some of these accumulators that they had as many as 24,coo sheep; and a good sheep, that was used to be sold for $2 s .4 d$. or $3 s$. at the most, was now from $4 s$. to $6 s$.; and a stone of clothing wool, that in some shires was accustomed to be sold for $18 d$. or $20 d$., is now $3 s .4 d$. to $4 s$, ; and in others, where it was $2 s .4 d$. to $3 s$. it is now $4 s .8 d$. to $5 s$.

It was therefore enacted that no man, with some exceptions, was to keep more than 2,000 sheep at one time in any part of the realm, though lambs under one year were not to count. The frequency of these laws proves their inefficacy, and the conduct of Henry VIII was the chief cause of it ; for while Parliament was complaining of the decrease of tillage he gave huge tracts of land taken from the monasteries to greedy courtiers, 
who evicted the tenants and lived on the profits of sheep farming. ${ }^{1}$ For the dissolution of the monasteries was now taking place, ${ }^{2}$ and the best landowners in England, some of whom farmed their own land long after most of the lay landlords had given it up or turned it into grass, and whose lands are said to have fetched a higher rent than any others, were robbed and ruined. Including the dissolution of the monasteries and the confiscation of the chantry lands in I 549 by Edward VI, about one-fifteenth of the land of England changed hands at this time. The transfer of the abbey lands to Henry's favourites was very prejudicial to farming ; it was a source of serious dislocation of agricultural industry, marked by all the inconvenience, injustice, and loss that attends a violent transfer of property. It is probable also that many of the monastic lands were let on stock and land leases; and the stock was confiscated, with inevitable ruin to the tenant as well as the landlord. ${ }^{3}$ And not only was a serious injury wrought to agriculture by the spoliation of a large number of landlords generally noted for their generosity and good farming, but with the religious houses disappeared a large number of consumers of country produce, the amount of which may be gathered from the following list of stores of the great Abbey of Fountains at the dissolution: 2,356 horned cattle, I,326 sheep, 86 horses, 79 swine, and large quantities of wheat, oats, rye, and malt, with 392 loads of hay. ${ }^{4}$ It must indeed have seemed to many as if the poor farmer was never to have any rest; no sooner were the long wars over and pestilences in some sense diminished, than the evils of enclosure and the dissolution of the monasteries came upon him. Many ills were popularly ascribed to the fall of the monasteries; in an old ballad in Percy's Reliques one of the characters says, in western dialect :-

1 Cunningham, Industry and Commerce, i. 489.

Dissolution of small monasteries, 1536 ; of greater, $1539-40$.

3 Thorold Rogers, History of Agriculture and Prices, iv. 129.

- Dugdale, Monasticon, v. 291. 
'Chill tell the what, good vellowe, Before the friers went hence, A bushel of the best wheate Was zold vor vorteen pence, And vorty eggs a penny That were both good and newe.'

NOTE. - If any further proof were needed of the constant attention given by Parliament to agricultural matters, it would be furnished by the Acts for the destruction of vermin. ${ }^{3}$ Our forefathers had no doubt that rooks did more harm than good, yearly destroying a 'wonderfull and marvelous greate quantitie of corne and graine'; and destroying the 'covertures of thatched housery, bernes, rekes, stakkes, and other such like'; so that all persons were to do their best to kill them, 'on pain of a grevous amerciament'.

${ }^{1} 24$ Hen. VIII, c. 10; 8 Eliz. c. 15 ; 4 Eliz. c. II ; 39 Eliz. c. 18. 


\section{CHAPTER VIII}

\section{FITZHERBERT. - THE REGULATION OF HOURS AND WAGES}

THE farming of this period is portrayed for us by Fitzherbert, the first agricultural writer of any merit since Walter of Henley in the thirteenth century. He was one of the Justices of Common Pleas, and had been a farmer for forty years before he wrote his books on husbandry, and on surveying in 1523 , so that he knew what he was writing about; 'there is nothing touching husbandry contained in this book but I have had experience thereof and proved the same.' In spite of the increase of grazing in his time he says the 'plough is the most necessarie instrument that an husbandman can occupy', and describes those used in various counties ; in Kent, for instance, 'they have some go with wheeles as they do in many other places'; but the plough of his time is apparently the same as that of Walter of Henley, and altered little till the seventeenth century. The rudeness of it may be judged from the fact that in some places it only cost Iod. or Is. though in other parts they were as much as $6 s$. or even $8 s$. He says ${ }^{1}$ it was too costly for a farmer to buy all his implements, wherefore it is necessary for him to learn to make them, as he had done in the Middle Ages before the era of ready-made implements, when he always bought the materials and put them together at home. On the vexed question of whether to use horses or oxen for ploughing, he says it depends on the locality; for instance, oxen will plough in tough clay and upon hilly ground, whereas horses will stand still; but horses go

1 Booke of Husbandry (ed. 1568), fol. 5. The surveyor of Fitzherbert's day combined some of the duties of the modern bailiff and land agent: he bought and sold for his employer, valued his property, and supervised the rents. 
faster than oxen on even ground and light ground, and are ' quicke for carriages, but they be far more costly to keep in winter.'

According to him, oxen had no shoes as horses had.' Here is his description of a harrow : it is 'made of six final peeces of timber called harow bulles, made either of ashe or oke; they be two yardes long, and as much as the small of a man's leg; in every bulle are five sharpe peeces of iron called harow tyndes, set somewhat a slope forward.' This harrow, drawn by oxen, was good to break the big clods, and then the horse harrow came after to break the smaller clods. It differed slightly from the former, some having wooden tines. For weeding corn the chief instrument 'is a pair of tongs made of wood, and in dry weather ye must have a weeding hoke with a socket set upon a staffe a yard long.' 2

He recommends that grass be mown early, for the younger and greener the grass is the softer and sweeter it will be when it is hay, and the seeds will be in it instead of fallen out as when left late; advice which many slovenly farmers need to-day. He does not approve of the custom of reaping rye and wheat high up and mowing them after, but advises that they be cut clean; barley and oats, however, should be commonly mown. Both wheat and rye were to be sown at Michaelmas, and were cast upon the fallow and ploughed under, two London bushels of wheat and rye being the necessary amount of seed per acre. In spite of his praise of the plough he allows that the sheep 'is the most profitablest cattel that a man can have', and he gives a list of their diseases, among the things that rot them being a grass called sperewort, another called peny grass, while marshy ground, mildewed grass, and grass growing upon fallow and therefore full of weeds were all conducive to rot. The chief cause, however, is mildew, the sign of whose presence is the honeydew on the oak leaves. In buying cattle to feed the purchaser is

1 Booke of Husbandry (ed. 1568), fol. vi.

2 Ibid. fol. $x v$. 
to see that the hair stare not, and that the beast lacks no teeth, has a broad rib, a thick hide, and be loose skinned, for if it stick hard to his ribs he will not feed ${ }^{1}$; it should be handled to see if it be soft on the forecrop, behind the shoulder, on the hindermost rib upon the huck bone, and at the nache by the tail. Among other diseases of cattle he mentions the gout, 'commonly in the hinder feet'; but he never knew a man who could find a remedy. He was a great advocate of enclosures; for it was much better to have several closes and pastures to put his cattle in, which should be well quick-setted, ditched, and hedged, so as to divide those of different ages, as this was more profitable than to have his cattle go before the herdsman (in the common field).

It will be seen from the above that Fitzherbert made no idle boast in saying he wrote of what he knew, and much of his advice is applicable to-day, though the time is past for the farmer's wife to 'wynowe all manner of cornes, to make malte, to shere corne, and in time of nede to helpe her husbande to fyll the mucke wayne or dounge carte, dryve the plough, lode heye, corne, and such other'; though she may go or ride to the market 'to sel butter, cheese, milke, eggs, chekyns, hennes, and geese.' ${ }^{2}$ It appears that the horses of England at this time had considerably deteriorated, for the statute 27 Hen. VIII, c. 6 , mentions the great decay of the breed, the cause it is stated being that ' in most places of this Realme little horsis and naggis of small stature and valeu be suffered to depasture and also to covour marys and felys of very small stature'; therefore owners and farmers of deer parks shall keep in every such park two brood mares of 13 'hand fulles' (hands) at least. Another statute, 32 Hen. VIII, c. I3, strove to remedy this evil by enacting that no entire horse under 15 hands was to feed on any forest, chase, waste, or common land.

1 Booke of Husbandry (ed. 1568), fol. xxix.

2 Fitzherbert adds pigs and all manner of cornes, so altogether the farmer's wife seems to have done as much as the farmer. 
This statute was a useful one, so also was 2 I Hen. VIII, c. 8 , which forbade for three years the killing of calves between January I and May I, under a penalty of $6 s .8 d$., because so many had been killed by 'covetous persons' that the cattle of the country were dwindling in number. Others, however, were merely meddlesome, and directed against that unpopular man the dealer. For instance, owners refusing to sell cattle at assessed prices were to answer first in the Star Chamber $(25$ Hen. VIII, c. I) ; and by 3 and 4 Edw. VI, c. I 9, no cattle were to be bought but in open fair or market, and not to be resold then alive, though a man might buy cattle anywhere for his own use. No person, again, was to resell cattle within five weeks after he bought them (5 Edw. VI, c. I4); and a common drover had by the same Act to have a licence from three justices before he could buy and sell cattle. We may be sure that these laws were more honoured in the breach than in the observance, as they deserved to be.

Hops were said to have been introduced from the Low Countries about the middle of Henry VIII's reign; but there can be no doubt that this is a mistake. It has been mentioned that they flourished in the gardens of Edward I, and a distinguished authority ${ }^{1}$ says the hop may with probability be reckoned a native of Britain; but it was first used as a salad or vegetable for the table, the young sprouts having the flavour of asparagus and coming earlier. Hasted, the historian of Kent, states ${ }^{2}$ that a petition was presented to Parliament against the hop plant in 1428 wherein it was called a 'wicked weed'. Harrison says, 'Hops in time past were plentiful in this land, afterwards their maintenance did cease, and now (cir. I 580) being revived where are anie better to be found ?' 3 Even then growers had to face foreign competition, as the customs accounts prove that considerable quantities were

s Description of Britain (Furnivall ed.), p. 325. 
imported into England. In $\mathrm{r}_{482}$ a cwt. was sold for $8 \mathrm{~s}$. and I cwt. $2 \mathrm{I} \mathrm{lb}$. for I $9 s .6 d$., an early example of that fluctuation in price which has long characterized them. ${ }^{1}$ Their average price about this time seems to have been $14 \mathrm{~s}$. $\circ \frac{1}{2} d$. a cwt.

During the Tudor period the number of day labourers increased, largely owing to the enclosures having deprived the small holder and commoner of their land and rights. But judging by the statutes those paid yearly and boarded in the farm house were still most numerous.

In 1495 the hours of labourers were first regulated by law. I The statute II Hen. VII, c. 22 , says that $23 \mathrm{Hen}$. VI, c. I2, ${ }^{2}$ was insufficiently observed; and besides increasing wages slightly set forth the following hours for work on the farm : the labourer was to be at his work from the middle of March to the middle of September before 5 a.m., and have half an hour for breakfast and an hour and a half for dinner and sleep, when sleep was allowed, that is from the middle of May to the middle of August ; when sleep was not allowed, an hour for dinner and half an hour for his nonemete or lunch; and he was to work till between 7 and 8 p.m. During the rest of the year he was to work from daylight to dark. The attempt to regulate hours, which seem fair and reasonable, no doubt met with better success than that to regulate wages, for $6 \mathrm{Hen}$. VIII, c. 3 (1 $5^{14}$ ), says the previous statutes had been very much disregarded, and sets down the rates once more :-

A bailiff's yearly wages, with diet, were to be not more than $£_{1} 6 s .8 d$., and $5 s$. for clothes.

A chief hind, carter, or chief shepherd, with diet, not more than $£$ I, and 5 s. for clothes.

A common servant or labourer, with diet, not more than $16 s .8 d$., and $4 s$. for clothes.

A woman servant, with diet, not more than ros., and $4 s$. for clothes.

By the day, except in harvest, a common labourer from

1 Thorold Rogers, History of Agriculture and Prices, iii. 254.

${ }^{2}$ See p. 71 . 
Easter to Michaelmas was to have $2 d$. with food and drink, $4 d$. without; and from Michaelmas to Easter $1 \frac{1}{2} d$ with food and drink, and $3 d$. without. In harvest :-

A mower, with food, $4 d$. a day; without, $6 d$.

A reaper, with food, $3 d$. a day; without, $5 d$.

A carter, with food, $3 d$.; without, $5 d$.

Other labourers, with food, $2 \frac{1}{2} d$.; without, $4 \frac{1}{2} d$.

Women, with food, $2 \frac{1}{2} d$. ; without, $4 \frac{1}{2} d$. 


\section{CHAPTER IX}

I $540-1600$

PROGRESS AT LAST.-HOP GROWING. - PROGRESS OF ENCLOSURE.-HARRISON'S 'DESCRIPTION'

THE period we have now reached was one of steady growth

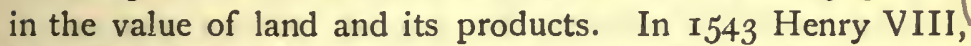
who had given away or squandered, in addition to the great treasure left him by his thrifty father, all the wealth obtained from the dissolution of the monasteries, debased the coinage in order to get more money into his insatiable hands, and prices went up in consequence. But there were other causes: the influx of precious metals from newly discovered America into Europe had commenced to make itself felt, and the population of the country began to grow steadily. Also, it must not be forgotten that the seasons, which in the early part of the century had been normal, were for the next sixty years frequently rainy and bad. It is unnecessary to say that this must have largely helped to raise the price of corn. The average price of wheat from $1540-1582$ was 13 s. $10 \frac{1}{2} d$. a quarter; from $1583-1702,39 s$. $0 \frac{1}{2} d$. Corn was still subject to extraordinary fluctuations: in 1557 , Holinshed says before harvest wheat was $53 s .4 d$. a quarter, malt $44 s$. After harvest wheat was $5 s$, malt $6 s .8 d$., the former prices being due to a terrible drought in England. Oxen in the period $1583-1702$ were worth $75^{\text {s. instead }}$ of under $£ \mathrm{I}$ in the period $1400-1540$. Wool was from $9 d$. to Is. a lb. instead of about $3 \frac{1}{2} d$., and all other farm products increased with these. ${ }^{1}$ Hops were from $1540-1582$ about $26 s .8 d$. a cwt., and from $1583^{-1} 700,82 s .9 \frac{1}{2} d$. In 1574 Reynold Scott

${ }^{1}$ See table at end, and Thorold Rogers's prices in Vol. V. of his great work. 
published the first English treatise on hops ${ }^{1}$, in which he says, 'one man may well keep 2,000 hils, upon every hil well ordered you shall have $3 \mathrm{lb}$. of hoppes at the least, one hundred pounds of these hoppes are commonly worth $26 \mathrm{~s} .8 \mathrm{~d}$., one acre of ground and the third part of one man's labour with small cost beside, shall yield unto him that ordereth the same.well, fortie marks yearly and that for ever,' an optimistic estimate that many growers to-day would like to see realized. 'In the preparation of a hop garden', says the same writer, ' if your ground be grasse, it should be first sowen with hempe or beanes which maketh the ground melowe, destroyeth weedes, and leaveth the same in good season for this purpose. ${ }^{2}$ At the end of Marche, repayre to some good garden to compound with the owner for choice rootes, which in some places will cost $5 d$. an hundredth. And now you must choose the biggest rootes you can find, such as are three or four inches about, and let every root be nine or ten inches long, and contain three joints.' Holes were then to be dug at least 8 feet apart, one foot square, and one foot deep, and in each two or three roots planted and well hilled up. Tusser, however, recommended them much closer:

'Five foot from another each hillock should stand, As straight as a levelled line with the hand.

Let every hillock be four foot wide.

Three poles to a hillock, I pas not how long,

Shall yield the more profit set deeplie and strong.'

Three or four poles were to be set to each hill 15 or 16 feet long, unless the ground was very rich, the poles 9 or $\mathrm{s} 0$ inches in circumference at the butt, so as to last longer and stand the wind well. After they were put up, the ground

1 'A perfite platforme of a Hoppegarden', in Arte of Gardening, by R. Scott, I 574.

2 Tusser recommends that the hopyard be dug. Thomas Tusser was born in Essex, about 1525, and died in 1580 . He led a roving life, which included a good deal of farming; but the statement that he died poor appears to be inaccurate. Much of his advice is not very valuable. 
round the poles was to be well rammed. Rushes or grass were used for tieing the hops. During the growth of the hops, not more than two or three bines were to be allowed to each pole; and after the first year the hills were to be gradually raised from the alleys between the rows until, according to the illustrations in Scott's book, they were 3 or 4 feet high, the 'greater you make your hylles the more hoppes you shall have upon your poals'. When the time for picking came, the bines when cut were carried to a 'floore prepared for the purpose', apparently of hardened earth, where they were stripped into baskets, and Scott thought that 'it is not hurtfull greatly though the smaller leaves be mingled with the hoppes'. In wet weather the hops were to be stripped in the house. The fire for drying hops was of wood, and some dried their hops in the sun, both processes to us appearing very risky; as the first would be too quick, and the latter next to impossible in September in England. They were sometimes packed in barrels, as Tusser tells us, 'Some close them up drie in a hogshead or vat, yet canvas or sontage (coarse cloth) is better than that.'

By this time England had largely changed from a corngrowing to a stock-raising country; Harrison, writing in the middle of Queen Elizabeth's reign, says, 'the soile of Britaine is more inclined to feeding and grazing than profitable for tillage and bearing of corne... and such store is there of cattle in everie place that the fourth part of the land is scarcely manured for the provision of graine.' But this statement seems exaggerated. We know that by Harrison's time enclosures had affected but a small area, and the greater part of the cultivated land was in open arable fields. The yield of corn was now much greater than in the Middle Ages; rye or wheat well tilled and dressed now produced $I_{5}$ to 20 bushels to the acre instead of 6 or 8 , barley $3^{6}$ bushels, oats 4 or 5 quarters, ${ }^{1}$ though in the north, which was still greatly behind the rest of

${ }^{\prime}$ Harrison, Description of Britain, p. I 10. 
England, crops were smaller. No doubt this was partly due to the much-abused enclosures: the industrious farmer could now do what he liked with his own, without hindrance from his lazy or unskilful neighbour. Tusser's preference for the 'several' field is very decided; comparing it with the 'champion' or common field he says :-

The countrie inclosed I praise the tother delighteth me not, There swineherd that keepeth the hog there neetherd with cur and his horne, There shepherd with whistle and dog be fence to the medowe and corne, There horse being tide on a balke is readie with theefe for to walke, Where all things in common doth reste corne field with the pasture and meade, Tho' common ye do for the best yet what doth it stand ye in steade? More plentie of mutton and beefe corne butter and cheese of the best. More wealth any where (to be briefe) more people, more handsome and prest (neat.) Where find ye? (go search any coaste) than there where enclosure is most.

More work for the labouring man as well in the towne as the fielde. For commons these commoners crie inclosing they may not abide, Yet some be not able to bie

a cow with her calf by her side.

Nor laie (intend) not to live by their wurke, But thievishly loiter and lurke.

What footpaths are made and how brode Annoiance too much to be borne, With horse and with cattle what rode is made thorowe erie man's corne.

But the rich graziers boasted that they did not grow corn because they could buy it cheaper in the market; and they are said to have traded on the necessity of the poor 
farmer to sell at Michaelmas in order to pay his rent, and when they had got the corn into their hands they raised the price. The corn-dealers of the time were looked upon with dislike by every one ; many of the dearths then so frequent, and nearly always caused by bad seasons, were ascribed to 'engrossers buying of corn and witholding it for sale'. By a statute of $155^{2}$ the freedom of internal corn trade was entirely suppressed, and no one could carry corn from one part of England to another without a licence, and any one who bought corn to sell it again was liable to two months' imprisonment and forfeited his corn. Although we shall see that this policy was reversed in the next century, the feeling against corn-dealers survived for many years and was loudly expressed during the Napoleonic war; indeed, we may doubt if it is extinct to-day.

Many of the fruits and garden produce, which had been neglected since the first Edward, had by now come into use again, 'not onlie among the poor commons, I meane of melons, pompions, gourds, cucumbers, radishes, skirets (probably a sort of carrot), parsneps, carrots, cabbages, navewes (turnip radishes (?)), turnips, ${ }^{1}$ and all kinds of salad herbes, but also at the tables of delicate merchants, gentlemen, and the nobilitie.' ${ }^{2}$ 'Also we have most delicate apples, plummes, pears, walnuts, filberts, \&c., and those of sundrie sorts, planted within fortie years past, in comparison of which most of the old trees are nothing worth: so have we no less store of strange fruite, as abricotes, almonds, peaches, figges, cornetrees (probably cornels) in noblemen's orchards. I have seen capers, orenges, and lemmons, and heard of wild olives growing here, besides other strange trees.' ${ }^{3}$

As a proof of the growth of grass in proportion to tillage

1 Usually grown in gardens, until the middle of the seventeenth century. Tusser also mentions them.

2 Description of Britain, ii. 324 (Furnivall ed.).

3 Harrison, Description of Britain, ii. 329. 
between the fourteenth and sixteenth centuries, Eden gives several examples, ${ }^{1}$ of which the following are significant :-

1339. 18 messuages in Norfolk had

1354. a Norfolk manor

1395. 2 messuages in Warwickshire

1560. 2 messuages in Warwickshire

I 567. a Norfolk estate .

1569. ", manor

$\begin{array}{cc}\text { Arable. Grass. } \\ \text { acres. } & \text { acres. } \\ 160 & 60 \\ 300 & 59 \\ 400 & 60 \\ 600 & 660 \\ 200 & 400 \\ 60 & 60\end{array}$

'Our sheepe are very excellent for sweetness of flesh, and our woolles are preferred before those of Milesia and other places.' $^{2}$ So thought Harrison and many English landowners and farmers too, so that legislation was powerless to stop the spread of sheep farming. In $\mathrm{I}^{\mathrm{I}} 7 \mathrm{7}$ a commission of inquiry instigated by Wolsey held inquisition on enclosures and the decay of tillage, and it seems to have been the only honest effort to stop the evil. It was to inquire what decays, conversions, and park enclosures had been made since 1489 , but the result even of this attempt was small. In I 535 a fresh statute, 27 Hen. VIII, c. 22, stated that the Act limiting the number of sheep to be kept had only been observed on lands held of the king, whereon many houses had been rebuilt and much pasture reconverted to tillage; but on lands holden of other lords this was not the case, therefore the king was to have the moiety of the profits of such lands as had been converted from tillage to pasture since $4 \mathrm{Hen}$. VII until a proper house was built and the land returned to tillage; but the Act only applied to fourteen counties therein enumerated. The enclosing for sheep-runs still went on, however, often with ruthless selfishness; houses and townships were levelled, says Sir Thomas More, and nothing left standing except the church, which was turned into a sheep-house :

' State of the Poor, i. 48-9. Blomefield's Norfolk, iv. 569, i. 5 I, i. 649. Dugdale, Warwickshire, p. 557.

${ }_{2}^{2}$ Description of Britain, iii. 5. 
'The towns go down, the land decays,

Of corn-fields plain lays,

Great men maketh nowadays

A sheepcot of the church',

said a contemporary ballad.

Latimer wrote, 'where there were a great many householders and inhabitants there is now but a shepherd and his dog.' 'I am sorie to report it,' says Harrison, ${ }^{1}$ 'but most sorrowful of all to understand that men of great port and countenance are so far from suffering their farmers to have anie gaine at all that they themselves become graziers, butchers, tanners, sheepmasters, and woodmen, thereby to enrich themselves.' The Act against pulling down farmhouses was evaded by repairing one room for the use of a shepherd; a single furrow was driven across a field to prove it was still under the plough; to avoid holding illegal numbers of sheep flocks were held in the names of sons and servants. ${ }^{2}$ The country swarmed with heaps of miserable paupers, 'sturdy and valiant' beggars, and thieves who, though hanged twenty at a time on a single gallows, still infested all the countryside, their numbers being swollen by the dissolution of the monasteries and the breaking up of the bands of retainers kept by the great nobles.

Rents also were rising rapidly. Latimer's account of his father's farm is too well known to be again quoted; his opinions were shared by all the writers of the day. Sir William Forrest, about 1540 , says that landlords now demand fourfold rents, so that the farmer has to raise his prices in proportion, and beef and mutton were so dear that a poor man could not 'bye a morsell'. 'Howe joyne they lordshyp to lordshyppe, manner to manner, ferme to ferme. How do the rych men, and especially such as be shepemongers, oppresse the king's people by devourynge their common pastures with

1 Descriplion of Britain (ed. Furnivall), ii. 243.

' - Froude, Hislory of England, v. III. 
the shepe so that the poore are not able to keepe a cowe, but are like to starve. And yet when was beef ever so dere or mutton, wool now $8 s$. a stone.'

'Now', says another, later in the century, 'I can never get a horse shoed under Iod. or $12 d$, when I have also seen the common pryce was $6 d$. And cannot your neighbour remember that within these thirty years I could bye the best pigge or goose that I could lay my hand on for four pence which now costeth $I 2 d$., a good capon for $3 d$. or $4 d$., a hen for $2 d$., which now costeth me double and triple.' 1

Parliament, of course, tried to regulate the price of food; an Act of $\mathrm{I}_{532}, 24 \mathrm{Hen}$. VIII, c. 3, ordained that beef and pork should be $\frac{1}{2} d$. a $\mathrm{lb}$. and mutton and veal $\frac{5}{8} d$. a $\mathrm{lb}$. The decrease in the number of cows also received its attention; 2 and 3 Philip and Mary, c. 3, states that forasmuch of late years a great number of persons have fed in their pastures sheep and cattle with no regard to breeding, so that there was great scarcity of stock, therefore for every 60 sheep kept one milk cow shall be kept, and for every I 20 sheep one calf shall be bred, and for every to head of horned cattle shall be kept one milk cow, and for every two cows so kept one calf shall be bred. The Act was to last seven years, but I3 Eliz. c. 25 made it perpetual.

In 1549 came the rising of Robert Kett in Norfolk, the last attempt of the English labourer to obtain redress of his wrongs by force of arms, though Kett himself belonged to the landlord class and took the side of the people probably by accident. The petition of grievances drawn up by his followers aimed at diminishing the power of lords of manors as regards enclosures, the keeping of dove-cots, and other feudal wrongs. 'We pray', said the insurgents, 'that all bondmen may be made free, for God made all free with His precious blood-shedding.' The rebellion came to nothing, and some of

1 'A compendious or brief examination of certain ordinary complaints', quoted by Eden, State of the Poor, i. I19. 
the abuses at which it was aimed were dying a natural death, though enclosure often acted hardly on the poor man.

The manorial system went on steadily decaying, and by this time the demesne lands had much diminished in area on most manors. Many parcels had been sold to the new landlord class, who had made their fortunes in the towns and, like most Englishmen, desired to become country gentlemen.

Much of the demesne had been sold in small lots to welloff tradesmen, and as the villeins had become copyholders a large part of the land was owned or occupied by yeomen or tenant farmers, who cultivated from 20 to I 50 acres. Many of the labourers also owned or rented cottages with 4 or 5 acres attached to them. Such was the rural society at the end of the Tudor period. The progress of enclosures helped to destroy this, for the labourers gradually ceased to own or occupy land, farms increased in size, the ownership of land came to be more and more the privilege of the rich, and people flocked in increasing numbers to the towns. ${ }^{1}$ In five Norfolk manors in Elizabeth's time only from one-seventh to one-tenth was in demesne, and little of what was left was farmed by the lord, but let to farmers on leases. ${ }^{2}$ On some manors the demesne land lay in compact blocks near the manor house; on others it was in scattered strips of various size; in others it lay in blocks and strips. The following particulars of a manor in Norfolk give a good picture of an estate in $1586-8$, the tenants on it, their rank, and the size of their holdings :-

\section{Horstead with Staninghall, 2,746 acres.}

The tenants with messuages in the village were:-

$$
\text { Acres. }
$$

Acres.

I. J. Topliffe, gentleman $\quad 280$

2. F. Woodhouse, Esquire - 270

3. R. Ward, gentleman

- 265

4. H. Shreve .

. 180

5. A. Pightling, widow . . 120

6. W. Rose's heirs . . I10

1 Transactions of the Royal Historical Society (New Series), xix. I03.

2 Ibid. xi. 74 sq. 


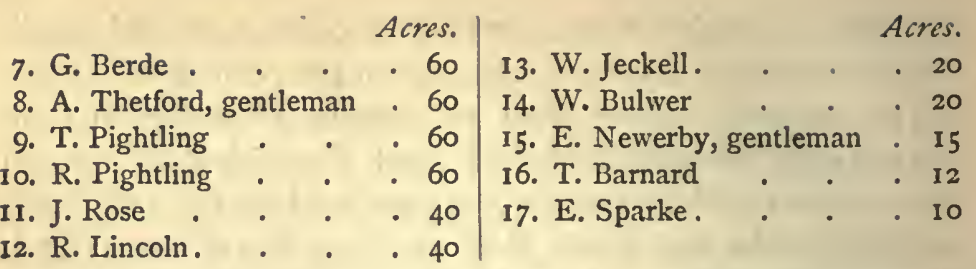

There were also 12 tenants without houses, holding from $\mathrm{I}$ to 20 acres; the demesne was 230 acres; there were two glebes containing 84 acres, and town lands of 7 acres. The waste amounted to $35^{\circ}$ acres, which by $\mathbf{5} 59$ had all disappeared.

On this manor the houses were not collected together in a village as usual in most parts of England, but scattered about the estate. In two other manors the amount of waste remaining at this period was very small, but in three others little had been 'approved' and much consequently remained; most of the 'approvements', where made, seem to have been of long standing, and all the enclosures made were for tillage, not for grass as we should expect. The $35^{\circ}$ acres of waste that remained at Horstead in $1586-8$ was enclosed in I 599 by agreement between the lords of the manor and the tenants on the following terms:-

1. Lords to take 80 acres in severalty.

2. Lords to reserve all rights to treasure trove, minerals, waifs, \&c., with right of entry to take the same.

3. All rights of pasture, shack, and foldage were to be extinguished on all lands in the village.

4. The tenants were to pay an annual quit rent of $£ 7$ I $4 s .5 d$. for their shares of the common.

Before a man enclosed he consolidated his holding by exchange, so as to bring it into a compact parcel instead of scattered strips, a very lengthy process; then he ploughed up the bounds between the strips; after which he changed the direction of the ploughing, ploughing the land crossways, a very necessary change, as it had all been ploughed length- 
ways for centuries; and lastly he erected his fences: the bounds of the strips, however, were sometimes left to show which were freehold and which copyhold. On the other hand; there were exceptions to the curtailment of the demesne : on an Oxfordshire manor of the sixteenth century the greater part of the 64 yard-lands of which it consisted had by then passed from the possession of the peasants to the private use of the lord of the manor. ${ }^{1}$ To each yard-land belonged a house and farmyard, 24 to $28 \frac{3}{4}$ acres of arable land, a share in the commonable meadows which for each occupier came to some 8 acres, also the right to turn out 8 oxen or cows, or 6 horses and 40 sheep on to the common pasture. Probably, as in other manors in ancient times, each occupier had a right to as much firewood as was necessary, and timber for building purposes and fences. The arable land lay in numerous small plots of half an acre each and less, mingled together in a state of great confusion, and was farmed on the four-field system-wheat, beans, oats, fallow-though 200 years before the three-field system had been most common in the district. Many of the common arable fields evidently often contained, in those days of poor cultivation and inefficient drainage, patches of boggy and poor land which were left uncultivated. ${ }^{2}$ In the rolls of the Manor of Scotter in Lincolnshire, in the early part of the sixteenth century, no one was to allow his horses to depasture in the arable fields unless they were tethered on these bad spots to prevent them wandering into the growing corn. Many of the other regulations of this manor throw a flood of light on the farming of the day. In 1557 it was ordered that no man should drive his cattle unyoked through the corn-field under a penalty of $3 s .4 d$.

${ }^{1}$ Nasse, Agricultural Community of the Middle Ages, p. 9. Archaeologia, xxxiii. 270.

2 In the still surviving open fields at Laxton, mentioned above, there are certain unploughed portions called 'sicks', or grassy patches, never cultivated.-Slater, op. cit. p. 9.

'Archaeologia, xlvi. 374. 
Eviery man shall keep a sufficient fence against his neighbour under the same penalty. No man shall make a footpath over the corn-field, the penalty for so doing being $4 d$. Every one shall both ring and yoke their swine before S. Ellen's Day. (probably May 3 ), under a penalty of $6 s .8 d$., the custom of yoking swine to prevent them breaking fences being common until recent times. It was the custom in some manors to sow peas in a plot especially set apart for the poor. Another rule was that no one should bake or brew by night for fear of burning down the flimsy houses and buildings. The penalty for ploughing up the balks. which divided the strips, or meere (marc) furrows as they were called in Lincolnshire, was $2 d$, a very light one for so serious an offence. In 1565 a penalty of IOs. was imposed on Thomas Dawson for breaking his hemp, i.e. separating the fibre from the bark in his large open chimney on winter nights, a habit which the manor courts severely punished owing to the risk of fire, for hemp refuse is very inflammable. It $\mathrm{I}_{578} 8$ it was laid down that every one was to sow the outside portion of their arable lands, and not leave it waste for weeds to the damage of his neighbours; and that those who were too poor to keep sheep should not gather wool before 8 o'clock in the morning, in reference to the custom of allowing the poor to pick refuse wool found on bushes and thorns, and this rule was to prevent them tearing wool from the sheep at night under that pretext. No man was to keep any beasts apart from the herdsman, for if the herdsman did not know the animals he could not tell them from strays. Every one was to sweep their chimney four times a year, for fear. of sparks falling on the thatch. No man was to suffer the nests of crows or magpies in his ground, but pull them down before May Day. In the meadows, before each man began to mow his grass-he-was to mark the exact limits of his own land with 'wadsticks' or tall rods, so that there could be no mistake as to boundaries. The health of the community and of the live stock also received attention : in ${ }^{58} 3$ AGRICULTURAL LIBRARY. 
one Pattynson was fined is. for allowing a 'scabbed' horse to go on the common; dead cattle were to be buried the day after death, and all unwholesome meat was to be buried.

Harrison praises the farmer of his day highly: ' the soyle is even now in these oure dayes growne to be much more fruitfulle; the cause is that our country men are grown more skilful and careful throwe recompense of gayne.' He was also doing well by means of his skill and care; and in spite of the raising of rents by the much-abused landlords; for in former times 'for all their frugality they were scarcely able to live and pay their rents on rent day without selling a cow or a horse'. Such also used to be their poverty, that if a farmer went to the alehouse, 'a thing greatly used in those days,' and there, ' in a braverie to show what store he had, did caste downe his purse and therein a noble or 6 shillings in silver unto them, it was very likely that all the rest could not lay downe so much against it.' And in Henry's time, though rents of $£ 4$ had increased to $£ 40, £ 50$, or $£ 100$, yet the farmer generally had at the end of his term saved six or seven years' rent, besides a 'fair garnish of pewter on his cupboard', and odd vessels, also ' three or four feather beds, so manie coverlids and carpets of tapestry, a silver salt, a bowle for wine, and a dozzen of spoones to furnish up the sute'. His food consisted principally of beef, and 'such food as the butcher selleth', mutton, veal, lamb, pork, besides souse, brawn, bacon, fruit, fruit pies, cheese, butter, and eggs. ${ }^{1}$ In feasting, the husbandman or farmer exceeded, especially at bridals, purifications of women, and such other meetings, where 'it is incredible to tell what meat is consumed and spent'. But, besides these, there were many poorer farmers who lived at home 'with hard and pinching diet'. Wheaten bread was at this time a luxury confined to the gentility, the farmer's loaf, according to Tusser, was sometimes wheat, sometimes rye, sometimes 
mastlin, a mixture of wheat and rye, though the poorer farmer on uninclosed land ate bread made of beans.

The poor ate bread of rye or barley, and in time of dearth of beans, peas, and oats, and sometimes acorns. ${ }^{1}$ According to Tusser, the labourer was allowed roast meat twice a week,

'Good plowmen looke weekly of custom and right, For roast meate on Sundaies, and Thursdaies at night';

and Latimer calls bacon 'the necessary meate' of the labourer, and it seems to have been his great stand-by then as now. The bread and bacon were supplemented largely by milk and porridge. $^{2}$ The statute, 24 Hen. VIII, c. 3, says that all food, and especially beef, mutton, pork, and veal, 'which is the common feeding of mean and poor persons,' was too dear for them to buy, and fixed the price of beef and pork at $\frac{1}{2} d$. a lb. and of mutton and veal at $\frac{5}{8} d$. a $1 \mathrm{~b}$.; but the statute, like others of the kind, was of little avail, and the price of beef was in the middle of the sixteenth century about $\mathrm{I} d$. a lb. or $8 d$. in our money. As the average price of wheat at the same date was I4s. a quarter, or about II2s. in our money, fresh meat was comparatively much cheaper, and it is no wonder that even the farmer could not afford wheaten bread regularly. Moryson, writing in Elizabeth's reign, says 'Englishmen eate barley and rye brown bread, and prefer it to white as abiding longer in the stomeck and not so soon digested '. 3

A tithe dispute at North Luffenham in Rutlandshire throws considerable light on the financial position of the various classes interested in the land about 1576 . At the trial several witnesses were examined, who all made statements as to the amount of their worldly wealth, and it is a noteworthy fact that even the humblest had saved something; perhaps because there was no poor law or State pension fund to discourage thrift. ${ }^{4}$ Thomas Blackburne, a husbandman, who

${ }^{1}$ In the reign of Mary, 'the plain poor people did make very much of acorns.' Cullum, Hawsted, p. I8I.

Itinerary, iii. 140.

2 Eden, State of the Poor, i. II6.

- Rutland Magazine, i. 64. 
had served his master as 'chief baylie of his husbandrie', had at the end of a long life saved $£ 40$. Another, William Walker, eighty years of age, during forty years of service to $\mathrm{Mr}$. John Wymarke had put by £Io. Robert Sculthorp, who had at one time been a farmer, was worth $£_{2} 66$ s. $8 d$., but the size of his farm is unfortunately not told us. Roland Wymarke, a gentleman farmer, who had farmed for forty years at North Luffenham, was little better off than Thomas Blackburne, the baylie, for he estimated his capital at $£ 50$. $£_{50}$, however, must not be taken as representing the average wealth of a 'gentleman', though a few hundred pounds was then considered a considerable fortune. In 1577 Thomas Corny, a prosperous landlord at Bassingthorpe, Lincolnshire, had a house with a hall, three parlours, seven chambers, a high garret, maid's garret, five chambers for yeomen hinds, shepherd, \&c., two kitchens, two larders, milk-house, brew-house, buttery, and cellar; and it was furnished with tables, carpets, cushions, pictures, beds, curtains, chairs, chests, and numerous kitchen and other utensils, besides a quantity of plate, which was then looked upon not only as a useful luxury but as a safe form of investment. The small squire was not nearly so well off as this. In 1527 the house of John Asfordby, who was of that degree, contained a hall, parlour, small parlour, low parlour, a chamber over the parlour, gallery chamber, buttery, and kitchen, and furniture was scanty, but the plate cupboard was well filled. ${ }^{1}$ A prosperous yeoman was often comparatively better off than the small squire. Richard Cust, of Pinchbeck in the same county, though his house was small, consisting only of a hall, parlour with chamber over, kitchen with chamber over, brew-house, milne-house (mill-house), and milk-house, was richer in furniture, possessing a folding-table, 4 chairs, 6 cushions, 27 pieces of pewter, ro candlesticks, 4 basins, I laver, 6 beds, and other articles. ${ }^{2}$

1 Victoria County History: Lincolnshire, ii. 331.

2 See Records of Cust Family, i. 56. 


\title{
CHAPTER, $\mathrm{X}$
}

\author{
$1540-1600$
}

LIVE STOCK.-FLAX. -SAFFRON.-THE POTATO. THE ASSESSMENT OF WAGES

THE cattle and sheep of this period have generally been described as poor animals, and no doubt they would seem small to us. To Jacob Rathgib, a traveller, writing in 1592 , they seemed worthy of praise: 'England has beautiful oxen and cows, with very large horns, low and heavy and for the most part black; there is abundance of sheep and wethers, which graze by themselves winter and summer without shepherds.' The heaviest wethers, according to him, weighed $60 \mathrm{lb}$. and had at the most $6 \mathrm{lb}$. of wool, a much heavier fleece than is generally ascribed to them; others had 4 or $5 \mathrm{lb}$. Horses were abundant, and, though low and small, were very fleet; the riding horses being geldings and generally excellent. Immense numbers of swine were in the country, ' larger than in any other.' Six years later another traveller, Hentzner, noticed that the soil abounded with cattle, and the inhabitants were more inclined to feeding than ploughing. He saw, too, a Berkshire harvest-home: 'As we were returning to our inn (at Windsor) we happened to meet some country people celebrating their harvest-home, their last load of corn they crown with flowers, having besides an image richly dressed by which perhaps they would signify Ceres; this they keep moving about, while men and women, men and maidservants, riding through the streets in the cart, shout as loud as they can till they arrive at the barn.' Harrison ${ }^{1}$ tells us, no doubt with patriotic bias, that 'our oxen are such as the like are not to be found in any country of Europe both for greatness of body and sweetness of flesh, their horns a yard 
between the tips.' Cows had doubled in price in his time, from $26 s .8 d$. to '53s. $4 d$. 'Our horses are high, but not of such huge greatness as in other places,' yet remarkable for the easiness of their pace; and 5 or 6 cart-horses will draw $30 \mathrm{cwt}$. a long journey, and a pack-horse will carry $4 \mathrm{cwt}$. without any hurt,-a statement which is one more proof of the poorness of the roads. The chief horse fairs were at 'Ripon, Newportpond, Wolfpit, and Harborow', where horse dealers were as great rogues as ever. Pigeons were still the curse of the farmer, and their cotes were called dens of thieves.

By the end of the sixteenth century, certainly by the first quarter of the seventeenth, the villein, who in the Middle Ages had formed the bulk of the population, had disappeared. ${ }^{1}$ It is probable that even at the beginning of the Tudor period the great majority of the bondmen had become free, and that the serf then only formed one per cent. of the population, and many of those had left the country and become artizans in the towns, for personal serfdom had outlasted demesne farming; though even there the heavy hand of the lord was upon them and enforced the ancient customs.

In the sixteenth century flax was apparently grown upon most farms, the statutes 24 Hen. VIII, c. 4 , and 5 Eliz., c. 5 , obliging every person occupying 60 acres of tillage to have a quarter of an acre in flax or hemp, and Moryson says the husbandmen wore garments of coarse cloth made at home, so did their wives, and 'in generall ' their linen was coarse and made at home. ${ }^{2}$

'Good flax and good hemp to have of her own In Maie a good housewife will see it be sowne',

sings Tusser. The statute of Henry VIII enjoined the sowing of flax and hemp because of the great increase of idle people in the realm, to which the numerous imports, especially linen cloth, contributed.

1 Transactions of the Royal Historical Society (New Series), xvii. 235.

2 Moryson, Itinerary (ed. 1617), iii. 179. 
Saffron also was much grown, that at Saffion Walden in Essex was said to be the best in the world, the profit from it being reckoned at $£ \mathrm{I}_{3}$ an acre. Its virtues were innumerable, if we may believe the contemporary writers ; it flavoured dishes, helped digestion, was good for short wind, killed moths, helped deafness, dissolved gravel, and, lastly, 'drunk in wine doth haste on drunkenesse.'

The most important novelty of this century was the potato, which the colonists, sent out in $\mathrm{I}_{5} 86$ by Sir Walter Raleigh, brought from Virginia to Ireland, though it had been introduced into Europe by the Spaniards before this. According to Gerard, the old English botanist, it was, on its first introduction from America, only cultivated in the gardens of the nobility and gentry as a curious exotic; and in 1606 it occurs among the vegetables considered necessary for a nobleman's household. ${ }^{1}$ It is curious to find Gerard comparing it to what he calls the 'common potato', in reality the sweet potato brought to England by Drake and Hawkins earlier in the century. In James I's reign the root was considered a great delicacy, and was sold to the queen's household at 2s. a lb., an enormous price.

Like most agricultural novelties it spread very slowly, but about the middle of the seventeenth century began to be planted out in the fields in small patches in Lancashire, whence it spread all over the kingdom and to France. ${ }^{2}$ At this date it was looked upon as a very second-rate article of food, if we may judge by the Spectator (No. 232), which alludes to it as the diet of beggars. About 1690, Houghton says, 'now they begin to spread all the kingdom over,' and recommends them boiled or roasted and eaten with butter and sugar. $^{3}$ Eden notes its increasing popularity during the eighteenth century, and by his time (the end of that century)

1 Archaeologia, xiii. 371.

2 In 1650 it was much cultivated about London.

${ }^{3}$ Collections on Husbandry and Trade, ii. 468. 
in many parts it was the staple article of food for the poor; in Somerset the children mainly subsisted on it, and in Devon it was made into bread. Its cultivation on a large scale in the field did not, however, spread all over England till the Napoleonic war, and the ignorance and prejudice against it lasted for long; even Cobbett called it 'the lazy root', and whole potatoes were used for seed regardless of the number of eyes.

In ${ }^{1563}$ was passed the famous Act, 5 Eliz., c. 4, which Thorold Rogers has asserted to be the commencement of a conspiracy for cheating the English workman of his wages, to tie him to the soil, to deprive him of hope, and to degrade him into irremediable poverty. ${ }^{x}$ The violence of this language is a prima facie reason for doubting the correctness of his assertion, which on examination is found to be grossly exaggerated. Under Richard II the justices were authorized to fix the rate of wages, provided they did not exceed the maximum fixed by Parliament. The Elizabethan statute abolished the maximum and left the justices to fix reasonable rates. So far from being an attempt to keep wages down it seems to have been an honest effort to regulate them according to prices, ${ }^{2}$ whereas most previous statutes had merely reduced wages. The preamble of the Act states this clearly enough, saying that the existing laws with regard to the hiring and wages of servants were insufficient, chiefly because the wages 'are in dyvers places to small and not answerable to this time respecting the advancement of prices in all things that belong to the said servants and labourers, the said lawes cannot conveniently without the great greefe and burden of the poore labourer and hired man be put in due execution'. But as several of these Acts were still beneficial it was proposed to consolidate them into one statute in order to banish idleness, advance husbandry, and give the labourer decent wages. It was enacted therefore that all persons

I Six Centuries of Work and Wages, p. 398.

${ }^{2}$ Cunningham, Industry and Commerce, ii. 38 . The Statute of Labourers of 135 I made the same effort, see p. 43. 
between the ages of twelve years and sixty, not being otherwise occupied, 'nor being a gentleman born, nor having lands of the yearly value of $40 s$., nor goods to the value of $£$ ro,' should be compellable to serve in husbandry with 'any person that keepeth husbandry' by the year, and the hours of work were re-enacted.

The rates of wages of artificers, husbandmen, \&c., were to be ascertained yearly by the justices and the sheriff, ' if he conveniently may,' at quarter sessions, 'calling unto them such discrete and grave persons as they shall thinck meete and conferring together respecting the plentie or scarcitie of the tyme and other circumstances necessary to be considered,' and the wages fixed were to be certified into Chancery. Then proclamations of the wages thus determined were to be made in the cities and market towns. Every person who gave higher wages than those established by the proclamation was to be imprisoned for ten days and fined $£ 5$, every receiver to be imprisoned twenty-one days. The importance still attached to the harvest season is shown by the section that all artificers and others were compellable to work in harvest or be put in the stocks two days and a night. For the better advancement of husbandry and tillage every householder farming 60 acres of tillage or more might receive an apprentice in husbandry, but no tradesman or merchant might take an apprentice save his own son, unless his parents had freehold of the annual value of 40 s.; and no person was to use ' any art mistery or manual occupation now in use' unless he had served seven years' apprenticeship to it. There can be no doubt that the clauses last quoted confined a large portion of the population to agricultural work, but as we know that the people were deserting the country and flocking to the towns, this must have seemed to the framers of the law very desirable.

This method of fixing wages was in force until 1814 , and its repeal then was entirely contrary to the opinion of the artizan class; but it may be doubted if the magistrates extensively 
used the powers given them by the Act, and wages seem to have been settled generally by competition. Several instances remain, however, of wages drawn up under this Act. Almost immediately after it was passed, in June ${ }^{564}$, the Rutland magistrates met under the Act, and stated that the prices of linen, woollen, leather, corn, and other victuals were great, so they drew up the following list of wages ${ }^{1}$ :-

A bailiff in husbandry, having charge of two plough lands, at least should have by the year $40 s$. , and $8 s$. for his livery.

A chief servant in husbandry, which can eire (plough), sow, mow, thresh, make a rick, thatch and hedge, and can kill and dress a hog, sheep, and calf, by the year $40 s$., and $6 s$. for his livery.

A common servant in husbandry, which can mow, sow, thresh, and load

a cart, and cannot expertly make a rick, hedge, and thatch, and cannot kill and dress a hog, sheep, or calf, by the year $33 s .4 d$., and 5 s. for his livery.

A mean servant in husbandry, which can drive the plough, pitch the cart, and thresh, and cannot expertly sow, mow, thresh, and load a cart, nor make a rick, nor thatch, by the year $24 s$, and $5 s$. for his livery.

The chief shepherd is only to receive $20 s$. and $5 s$. for his livery ; but this must be an error, as in the statutes 6 Hen. VIII, c. 3 , and $23 \mathrm{Hen}$. VI, c. I2, he was placed next the bailiff as we should expect.

These wages, were evidently 'with diet', and show a considerable advance on those fixed by $6 \mathrm{Hen}$. VIII, c. $3{ }^{2}$ By the day the ordinary labourer was to have $6 d$. in winter, $7 d$. in summer, and $8 d$. to ro $d$. in harvest time, 'finding himself.' A mower with meat earned $5 d$,, without meat Iod. a day; a man reaper with meat $4 d$., without $8 d$.; a woman reaper $3 d$. and $6 d$.

As the price of corn and meat was three times what it had been in the fifteenth century, and the labourers' wages, taking into consideration his harvest pay, not quite double, the Rutland magistrates hardly observed the spirit of the Act. Rutland,

1 Thorold Rogers, History of Agriculture and Prices, iv. 120 ; and Work and Wages, p. 389. ${ }^{2}$ See p. 87 . 
moreover, judging by the assessments of the time, was a county where agriculture was very flourishing; and thirty years after we find in Yorkshire that the winter wages of the labourer were $4 d$. and the summer $5 d$. a day: that is, he had little more wages than in the fifteenth century, with provisions risen threefold. At Chester at the same date his day's wages were to be $4 d$. all the year round. ${ }^{1}$ In I6 Io the Rutland magistrates at Oakham ${ }^{2}$ decreed that an ordinary labourer was to have $6 d$. a day in winter and $7 d$. in summer, the same wages as in 1564 , yet wheat in that year averaged $32 s .7 d$. a quarter. A bailiff by the year was now advanced to $52 s$., a manservant of the best sort, equal no doubt to the chief servant in husbandry, to $50 s$., a 'common servant' to $40 \mathrm{~s}$., and a 'mean servant' to $29 \mathrm{~s}$., but all without livery. At Chelmsford, in $165 \mathrm{I}$, there was a very different rate fixed, the ordinary labourer getting from $I s$. to Is. $2 d$. a day; but this seems to have been exceptional, as at Warwick in 1684 he was only to have $8 d$., and as late as I 725 in Lancashire $9 d$. to Iod. a day. ${ }^{3}$ In 1682 , by the Bury St. Edmunds assessment, a common labourer got rod. a day in winter and Is. in summer, and a reaper in harvest Is. $8 d$. By the year a bailiff was paid $£ 6$, a carter $£ 5$, and a common servant $£_{3}$ Ios., of course with food. ${ }^{4}$ These figures clearly prove that the wages fixed by the magistrates were often terribly inadequate, though it must be said in their defence that the great rise in prices probably struck them as abnormal and not likely to last. It should be remembered, too, that besides his wages the labourer and his family had often bye industries such as weaving to fall back upon, and in most parts of England still a piece of common land to help him.

1 Thorold Rogers, Work and Wages, pp. 390-r.

2 Archaeologia, xi. 200.

3 Thorold Rogers, Six Centuries of Work and Wages, p. 396.

1 Cullum, Harwsted, p. 215. It is strange to find food reckoned so highly; if the common labourer at Hawsted received his food, he was only paid $5{ }^{d}$. a day in winter, and $6 d$. in summer; if one man's food was reckoned at half his wages, how far did the other half go in feeding and clothing his family? 


\section{CHAPTER XI \\ $1600-1700$}

CLOVER AND TURNIPS.-GREAT RISE IN PRICES. MORE ENCLOSURE.-A FARMING CALENDAR

THE seventeenth century was one of considerable progress in English agriculture. The decay of common-field farming was enabling individual enterprise to have its way. The population was rapidly growing; by 1688 the returns of the hearth tax prove that the northern counties were nearly as thickly populated as the southern, and prices during the first half were continually rising, though after that they remained almost stationary, since the effect of the influx of precious metals from the New World was exhausted. In the first half of the century John Smyth ascribes the advance of rents to 'the Castilian voyages opening the New World, whereby such floods of treasure have flowed into Europe that the rates of Christendom are raised near twentyfold'.

But the greatest agricultural event of the century was the introduction of clover and the encouragement of turnips as grown in Holland, by Sir Richard Weston, about 1645. No doubt the turnip was already well known in England. Tusser and Fitzherbert both mention it, apparently as a garden root only; but Gerard in his Herbal, 1597, says it grew in fields 'and divers vineyards or hoppe gardens in most places of England ', which certainly points to an effort having been made generally to use it as a field crop whenever an enclosed space gave it some protection from the depredations of the common herds. However, its cultivation must have declined, as long after this it was regarded as a novelty as a fieli crop in most parts of England. ${ }^{1}$ In Holland it had been used in

${ }^{\prime}$ R.A.S. E. Journal, 1896, pp. 77 sq., and Gerard, Herbal (ed. 1633), p. 232. 
the field universally, and this use with that of 'great', as it was called, or broad clover, Weston pressed on the English farmer. But their progress was wofully slow. At Hawsted in Suffolk clover and turnips were first sown about 1700 , and the eastern portion of England was far ahead of the north and west; as late as 1772 Arthur Young wrote that 'sainfoin, cabbages, potatoes, and carrots are not common crops in England; I do not imagine above half or at most two-thirds of the nation cultivate clover.' 1 Yet their introduction must have been of the greatest benefit to the farmer and the public; his stock of hay was increased, he could utilize his fallows, and keep a much larger head of stock through the winter, who would give him a greater quantity of manure. Every one where turnips were grown could now have fresh meat during the winter. The slow progress of these great blessings is perhaps the strongest testimony in our history of the innate conservatism of the farmer. The green crop was for long considered to be suited only to the garden, and as our forefathers were prejudiced against the spade it was difficult to get such crops cultivated even there; but it should also be remembered that no crop was possible in the common fields which did not come to maturity before Lammas, unless some special agreement was made as to it. ${ }^{2}$ Clover, Sir Richard Weston said, thrives best when sown on the worst and barrenest ground, which was to be pared and burnt, and unslaked lime added to the ashes. Then it was to be well ploughed and harrowed, and about Io lb. of seed sown per acre in the end of March or in April. 'It will stand five years, and then when ploughed up will yield three or four years running rich crops

${ }^{1}$ About 1684, John Worlidge wrote to Houghton that sheep fatted on clover were not such delicate meat as the heath croppers, and that sheep fatten very well on turnips. Houghton, Collection for Improvement of Husbandry, iv. 142. This is said to be the first notice of turnips being given to sheep.

${ }_{2}$ R.A.S.E. Journal, 1896 , p. 77 . One of the proofs of the rarity of vegetables among the poorer classes of England, especially in the Middle Ages, is the fact that rents paid in kind never included them. 
of wheat, and then a crop of oats, after which you may sow clover again.'

In the seventeenth century the practice of liming and marling, which had been largely discontinued since the fourteenth century, was revived (Westcote, in his Viere of Devon in 1630 , calls liming, \&c., a new invention), and there was also a great improvement in implements. Patents were taken out for draining machines in 1628 , for new manures in $1633-6$, ploughs $1623-7$ and 1634 , mechanical sowing $1634-9$. Only six were taken out, however, between 1640 and 1760 that concerned agriculture. ${ }^{1}$ The Civil War checked the improvement, for though the great mass of the people had nothing to do with either party, the country was of necessity in a very unsettled state, and both sides plundered indiscriminately. Yet in some parts, as in Devonshire, so many of the able men served in the two armies, that few but old men, women, and children were left to manage the farms, and even they were afraid to grow more than enough to supply themselves since both armies seized the crops. $^{2}$ These bad effects lasted for some time afterwards; Chapple, a Devonshire land agent of the eighteenth century, says he had talked with people who remembered the state of husbandry in the last ten or twelve years of the reign of Charles II, when in many parts of Devonshire an acre or two of wheat was esteemed a rarity.

That the rate of progress in the century was not more rapid is attributed by Blyth to several causes:-

I. Want of leases, by which tenants were deprived of security.

2. Discouragement to flood (irrigate) land, from the risk of law suits with neighbours.

3. Intermixture of different properties in common fields.

4. Unlimited pasturage on commons, by which they were overstocked.

1 R.A.S. E. Journal, 1892, p. 19.

${ }^{2}$ Chapple, Review of Risdon's Survey of Devon (1785), p. 17 n. Victoria County History: Devonshire, Agriculture. 
5. The want of a law compelling all men to kill moles.

6. The excessive number of water-mills, to the great destruction of much gallant land. ${ }^{1}$

The average price of wheat during the seventeenth century was 4Is. a quarter, of barley 22s., and oats I4s. $8 \frac{1}{2} d$. Oxen averaged about $£_{5}$ apiece, cows much less, about $£_{3}$, and there was not much change in their value during the century. Sheep were about IOs. $6 d$., and a cart-horse in the first half of the century from $£_{5}$ to $£_{10}$, in the second half from $£ 8$ to EI5. Beef rose from $2 d$. a lb. in the early part of the century to $3 d$. at the close of it. Wool remained stationary at from $9 d$. to Is. per lb.

${ }^{2} \mathrm{~A}$ proclamation of ${ }^{6} 633$ fixed the following prices for London poulterers and victuallers :-

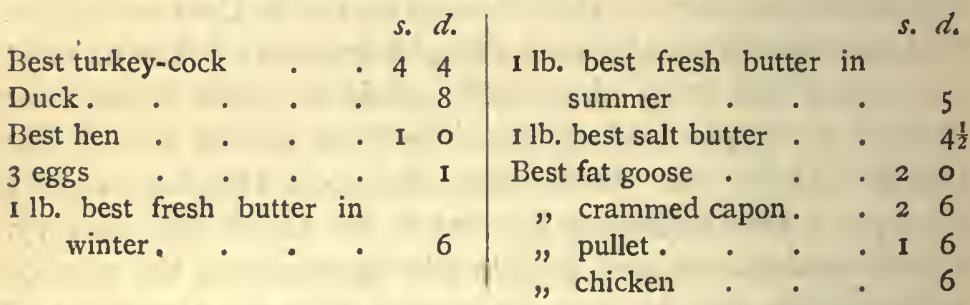

According to the Manydown Manor Rolls the Wootton churchwardens in I600 paid from $8 s$. to I Is. for calves, $4 s .4 d$. for a fat lamb, $8 s$. for a sheep, $6 s$. $8 d$. for a barren ewe, $6 d$. for a couple of chickens, $1 s$. $6 \mathrm{~d}$. for 500 faggots. ${ }^{3}$

After the restoration in 1660 another period of prosperity set in, 4 and altogether the century was a prosperous one for farmers and manufacturers. The newly established Royal Society materially helped agriculture. 'Since his majesty's

1 Blyth was a great advocate of enclosure. 'Live the commoners do indeed', he says, 'very many in a mean, low condition, with hunger and ease. Better do these-in Bridewell." What they get they spend. And can they make even at the year's rent?'

2 Rymer, Foedera (Orig. ed.), xix. 512.

${ }^{3}$ Manydozon Manor Rolls, Hampshire Record Society, p. 172.

4 Thorold Rogers, Work and Wages, p. 459. 
most happy restoration the whole land hath been fermented and stirred up by the profitable hints it hath received from the Royal Society, by which means parks have been disparked, commons enclosed, woods turned into arable, and pasture lands improved by clover, St. foine, turnips, cole-seed, and many other good husbandries, so that the food of cattle is increased as fast, if not faster, than the consumption, and by these means the rent of the kingdom is far greater than ever it was.' 1 The century was distinguished also for the curious number of cycles of good and bad seasons; I646-50 were years of prolonged dearth, wheat reaching an enormous price, and I66I-2 were famine years, while the end of the century was long famous for its barren years.

With the prices of produce rents rose enormously. Very early in the century ${ }^{2}$ rents of arable land had increased ninefold, since the fifteenth century, and by 1688 Davenant and King estimated the average rent of arable land in England at $5 s .6 d$. per acre and of permanent grass at $8 s .8 d$. Perhaps this is too high an estimate, as on the Belvoir estate of 17,837 acres in 1692 the rental all round was $3^{s .9} \frac{1}{4} d$. an acre for land above the average in quality, though it must be remembered that the Earls and Dukes of Rutland were indulgent landlords.

The History of Hawsted affords a valuable index of the increase of rents at this period. ${ }^{3}$ In 1500 the average rent was Is. $4 d$. an acre; in 1572,39 acres of arable, méadow, and pasture were let for $2 s .3 d$. an acre, the landlord, it is interesting to notice, reserving the right of hawking, netting rabbits, hunting, and fowling; and about the same date other lands

1 Houghton, Collections, Ecc., ii. 448:

2 Thorold Rogers, History of Agriculture and Prices, v, p. vii. Cf. p. I39 infra.

3 Cullum, Hawsted, pp. 196 et seq. In the Hawsted leases, at the end of the sixteenth and beginning of the seventeenth centuries, it is noteworthy that there were, at a time of repeated complaints against laying down land to pasture, clauses against breaking up pasture land. 
on the estate were let at Is. $3 d$. and Is. $6 \mathrm{~d}$. an acre, so that there had not generally been much advance since I500, which is what we should expect, as the great rise took place at the end of the sixteenth and the beginning of the seventeenth centuries. In 1589 , therefore, it is not surprising to find that 40 acres of meadow and pasture let at $5 \mathrm{~s}$. an acre, and in I 6 I I some buildings and 155 acres of park at IIs. an acre. In 1616,366 acres of arable and pasture and 39 acres of meadow were valued at I2s. an acre for letting, and the Hall Farm of I75 acres ( $8 \frac{1}{2}$ acres meadow) at ros.; and Great Pipers Farm of 138 acres ( 8 meadow) at $7 s$., while meadow and pasture near the mansion was valued at 2 Is. an acre.

In 1658 the rent of the Hall Farm had advanced from Ios. an acre to about $13^{s .,}$ though in 1682 it went down to IIs. $6 d^{1}{ }^{1}$ According to the survey of the Manor of Manydown in Hampshire in 1650 , meadow land was worth $20 s$. an acre, pasture $8 s$. to IOs., arable from $2 s$. to Ios., the latter showing a great variation in quality. ${ }^{2}$ In 1723 Bryers Wood Farm at Hawsted, which had been let in 1620 for $£^{1} 5$, was let at $£ 295^{s}$. These rents are considerably higher than the estimate of Davenant and King ; but it must be remembered that they were for land in the parts of England, where farming was at its best, and they, in accounting for the whole country, had to take into consideration a vast amount of land in the north and west which was worth very little. In the Rawlinson Collection ${ }^{3}$ in the Bodleian Library is a rental of Lord Kingston's estate in north Nottinghamshire in 1689 , the rents averaging ros. an acre; but this was an exceptionally good estate, much of the property being meadow and pasture. The farm-houses also were above the average, while in two of the parishes the tenants had rights of common, and in two others the tenancies were tithe free. There was very little arable land on the estate,

1 In 1677 there were complaints of a fall in rents.

2 Manydown Manor Rolls, Hampshire Record Society, pp. $178 \mathrm{ef} \mathrm{seq.}$

${ }^{3}$ Rawl. A. 170, No. ior. 
three small holdings letting for $6 s .8 d$. an acre; and some of the pasture land was let at $14 s$., I 5 s. $6 d$., and even I8s. an acre. The largest farm, Saundby Hall, of 607 acres, nearly all meadow and pasture, was 9s. Iod. an acre. The cottages were fortunate in having pieces of land attached to them. In Saundby, Richard Ffydall rented a cottage and 2 acres of arable land for $£ \mathrm{I} I 3 s .4 d$.; Widow Johnson a cottage and yard for $13 s .4 d$.; William Daubney a cottage with $6 \frac{1}{2}$ acres of arable and $5 \frac{1}{2}$ acres of pasture for $£ 7 \mathrm{r} 8 \mathrm{~s}$. $6 d$. A farm in Scrooby, consisting of a messuage, cottage, and II 3 acres of arable, meadow, and pasture, only let at $£ 23$.

As to the freehold value of land, in I62I, according to D'Ewes, it was worth from sixteen to twenty years' purchase ; yet, in 1688 , Sir Josiah Child said that lands now sell at twenty years' purchase, which fifty or sixty years before sold at eight or ten; and he also states, 'the same farms or lands to be now sold would yield treble and in some cases six times the money they were sold for fifty years ago'. ' Davenant puts land at twelve years' purchase in 1600 , at eighteen years in $1688 .^{2}$ In 1729 the price of land was said to be twenty-seven years' purchase. $^{3}$

The legislation against laying down tillage to grass was continued until the end of the sixteenth century. The statute 39 Eliz., c. I, repealed $4 \mathrm{Hen}$. VII, c. I9, and all other Acts against pulling down houses, and provided that a house of husbandry should be a house that hath or hath had 20 acres of arable land. All such houses which had been destroyed during the last seven years were to be rebuilt, and if destroyed more than seven years only one-half was to be rebuilt; but to each of them at least 40 acres of land were to be attached.

1 McPherson, Annals of Commerce, ii. 483.

2 Ibid. ii. 630 .

s Ibid. iii. 147. The rental of the lands in England in 1600 was estimated by Davenant at $£ 6,000,000$, in 1688 at $£ 14,000,000$; and in 1726 by Phillips at $£ 20,000,000$. Ibid. iii. 133. In 1850, Caird estimated it at $£ 37,412,000$. 
The next statute, 39 Eliz., c. 2, sets forth once more the advantages of tillage, viz. the increase and multiplying of people for service in the wars, and in time of peace the employment of a greater number of people, the keeping of people from poverty, the dispersal of the wealth of the kingdom in many hands, and 'the standing of this realm upon itself without depending upon foreign countries ${ }^{1}$;' and therefore enacts that lands converted from tillage to pasture shall be restored to tillage within three years, and lands then in tillage should be so continued; but this was only to extend to twenty-three counties, and omitted most of those in the south-west. At the beginning of the seventeenth century a reaction set in; the price of corn had risen immensely and continued to do so, the price of wool remained stationary, and tillage was as profitable as grass. In I620 Coke speaks of the man who only kept a shepherd and a dog as one who never prospered. In 1624 several of the tillage laws were repealed. ${ }^{2}$

As an example of the unenclosed fields, at the end of the sixteenth century, we may take the common fields at Daventry, which were three in number, containing respectively 368 , $3^{8} 3$, and 524 acres, divided into furlongs, a term which had now a very wide signification, each of which was subdivided into lands nearly always half an acre in extent, several of these lands when adjoining being often held now by the same owner. One furlong may be taken as an example. It was 37 acres I rood in extent, and contained ninety-six lands, owned by seventeen people. The meadows were divided still more minutely, some of the smaller portions being only a quarter of an acre. each. The largest meadow contained 50 acres, divided among fifty-three people. In the manor, besides the arable and meadow, there were 300 acres of

1. With what horror would those legislators have contemplated England's position to-day, when a temporary loss of the command of the sea would probably ruin the country.

2 2I Jac. I, C. 28. 
common pasture, a park, and a small wood. There were forty-one freeholders and many leasehold tenants, the average freehold being 34 acres, the average leasehold only half an acre, small holdings being the usual feature of the unenclosed township.

In the seventeenth century the price of wool ceased to operate as a cause of enclosure, but in many parts the change to pasture continued, owing to the rise in pricel of cattle and of wages. The same reason, too, for laying, down land to grass that had been so powerful in the preceding centuries still existed, the common arable fields needed rest from continual cropping and poor. manuring, while good crops of corn could be grown from the virgin soil of the newly enclosed waste. The preamble of the Durham decrees clearly states this: 'the land is wasted and worn with continual ploweing, and thereby made bare, barren, and very unfruitfull.' ' We may, therefore, take Coke's words as inapplicable to many districts. In the seventeenth century there were several methods of enclosing. Sometimes the lord of the manor enclosed and left the land of the tenants still in common; or a tenant enclosed piece by piece; or enclosures were made by Act of Parliament, the earliest of which for common fields was passed in the time of James I, a method at this period very seldom used; or there was an agreement between lord and tenants often authorized by the Courts of Chancery or Exchequer.

Besides enclosure, another process was going on, the consolidation of farms by the amalgamation of small holdings into larger ones. Farm-houses, as we see them to-day, began to appear on the holdings thus consolidated, instead of being grouped together in villages. A writer in 1604 says, 'we may see many of their houses built alone like raven's nests, no birds building neere them,' so unwonted was the sight of isolated dwellings in most places at the time.

1 Transactions of the Royal Historical Society (New Series), xix. 116. 
However, in $163^{\circ}$ Charles I went back to the policy of his forefathers and issued letters to certain of the Midland counties ordering all enclosures of the last two years to be removed, and Commissions were issued to inquire into the matter in 1632,1635 , and $16{ }_{3} 6,{ }^{1}$ the chief evil feared from enclosures being depopulation, and enclosers were prosecuted in the Court of Star Chamber.

The assertion that enclosures ceased during the seventeenth century has been proved inaccurate by modern research, and there is no doubt that they went on continuously. In 1607 , in the Midlands, the enclosing of land produced serious armed resistance, probably because the Midland counties were then the great corn-growing district of England, and the change to pasture and the consolidation of farms displaced a larger population there than elsewhere. Between $16_{2} 8$ and $16_{30}$ enclosures in Leicestershire, for instance, were very numerous, no less than 10,000 acres being enclosed in that time, most of which was converted to pasture. The attempt of the Government to check the movement, initiated by Charles I, seems to have had considerable effect, but died away with the Civil War, and though other attempts were made under the Commonwealth they came to nothing, and from this time enclosures went on unchecked by the Government, ${ }^{2}$ and were soon to have its active support. Yet there was a vast amount still in common field: the whole of the cultivated land of England in 1685 was stated by King and Davenant to amount to not much more than half the total area, and of this cultivated portion threefifths was still farmed on the old common-field system. Northamptonshire, Leicestershire, Rutland, Huntingdonshire, and Bedfordshire were comparatively unenclosed. ${ }^{3}$ From the books and maps of the day 'it is clear that many routes

1 Transactions of the Royal Historical Society (New Series), xix. 127.

2 Ibid. 130.

3 See article in Transactions of the Royal Historical Society (New Series), xix. 
which now pass through an endless succession of orchards, corn-fields, hay-fields, and bean-fields then ran through nothing but heath, swamp, and warren. In the drawings of an English landscape made in that age for the Grand Duke Cosmo scarce a hedgerow is to be seen. ..... At Enfield, hardly out of sight of the smoke of the capital, was a region of fiveand-twenty miles in circumference which contained only three houses and scarcely any enclosed fields.' 1 The enclosure of these areas was to be mainly the work of the latter half of the eighteenth and the first quarter of the nineteenth centuries.

The amount of enclosure in the fifteenth, sixteenth, and the first half of the seventeenth centuries was, according to the latest research, much, and perhaps very naturally, exaggerated by contemporaries. Between $1455-1607$ the enclosures in twenty-four counties are said to have amounted to some 500,000 acres, or 2.76 of their total area, ${ }^{2}$ but the evidence for this is by no means conclusive. However, there seems no reason to doubt that the enclosure of this period was but a faint beginning of that great outburst of it that marked the agrarian revolution of the middle of the eighteenth century, and that it was mainly confined to the Midland counties. Mr. Johnson, in his recent Ford Lectures, has stated that the enclosure of the sixteenth and seventeenth centuries was not accompanied by very much direct eviction of freeholders or bona fide copyholders of inheritance; yet the small holder suffered in many ways, e.g. by the lord disproving the hereditary character of the copyhold, or by changing copyholds of inheritance into copyholds for lives or leases for lives or years.

1 Macaulay, History of England, ch. iii.

${ }^{2}$ Quarterly Journal of Economics, xvii. 587. Considering that the legislature of the sixteenth century was against enclosure and depopulation, it is hard to understand 31 Eliz., c. 7, which forbade cottages to be erected unless 4 acres of land were attached thereto, in order to avoid the great inconvenience caused by the 'buyldinge of great nombers and multitude of cottages, which are daylie more and more increased in many partes of this realme'. How was it that cottages had increased so much in rural districts, which are of course alluded to, in spite of enclosure? 
$\mathrm{He}$ and his successors could then refuse to renew at the termination of lives or years except on payment of a practically prohibitory fine. In short, though there was not much violation of legal right there was much injustice, and enclosure, though its effects were exaggerated at this period, certainly tended to displace the small landholder. It does not appear, however, that the moderate-sized proprietors were seriously affected. Many of the larger freeholders and copyholders on manors enclosed on their own account, and perhaps increased at the expense of the very large and the very small. Indeed, the decrease of small landowners was chiefly due to political and social causes. The old self-sufficing, agricultural economy of England, which we have seen beginning to break up in the fourteenth century, was becoming thoroughly disintegrated. The capitalist class was increasing; the successful merchant and lawyer were acquiring land and becoming squires; there was an intense land hunger. Simon Degge, writing of Staffordshire in 1669 , says that in the previous sixty years half the lands had changed owners, not so much as of old they were wont to do, by marriage, but by purchase; and he notices how many lawyers and tradesmen have supplanted the gentry. ${ }^{1}$

In fact, there was a much freer disposal of lands from the end of the fifteenth century, when the famous Taltarum's case enabled entailed estates to be barred, until the Restoration, than there has been before or since. For these two hundred years the courts of law and parliament resisted every effort to re-establish the system of entails; the owners of land constantly multiplied, and this tendency must have counteracted the displacement of the small holder by enclosure. Sir Thomas Smith, writing towards the end of the sixteenth century, says that it was the yeomen who bought the lands of 'unthrifty gentlemen;' and Moryson tells us that 'the buyers (excepting lawyers) are for the most part citizens 
and vulgar men'.1 It became one of the boasts of England that she had a large number of yeomen farming their own land. During the Civil War, however, it became important to landowners to protect their properties in the interest of children and descendants from forfeiture for treason. The judges lent their aid, and the system of strict family settlements was devised, under which the great bulk of the estates in England are now held. This system favoured the accumulation of lands in a few hands and the aggregation of great estates, and was largely responsible for the disappearance of the small freeholder.

In reviewing the progress of agriculture in the seventeenth century, the drainage of the fen country of Lincolnshire and the adjoining counties must not be forgotten. It had been for centuries the scene of drainage operations on a more or less extended scale, few of which, however, met with success; but in the seventeenth century the growing value of land caused a serious revival of these efforts. Attempts made under Elizabeth and James I had only succeeded in rescuing a certain amount of land for pasture, ${ }^{2}$ but in the reign of Charles I the scheme of Cornelius Vermuyden was more successful. His system, however, was defective, and in the reign of Charles II the Bedford Level was in a lamentable state and in danger of reverting to its primitive condition. Many of the works too were destroyed by the 'stiltwalkers', and in $\mathbf{I} 793$ Maxwell states that out of 44,000 acres of fen land in Huntingdonshire only 8,000 or 10,000 were productive ${ }^{3}$; and in 1794 Stone tells us that the commons round the Isle of Axholme were chiefly covered with water. ${ }^{4}$ Still to Vermuyden and his contemporaries must be assigned the credit of the first comprehensive scheme for rescuing these fertile lands from the waters that covered them.

1 Hasbach, op. cit. p. 44 .

2 Cunningham, Industry and Commerce, i. 187.

3 General View of Hunts., p. 8. General View of Lincoln, p. 29. 
At the commencement of this important century an old calendar of 1606 clearly sets forth the farming work of the year ${ }^{1}:-$

January and February are the best months for ploughing for peas, beans, and oats, and to have peas soon in the year following sow them in the wane of the moon at S. Andrewstide before Christmas; which may be compared to Tusser's advice for February,

'Go plow in the stubble, for now is the season For sowing of fitches of beans and of peason.'

'Clean grounds of all such rubbish as briars, brambles, blackthorns, and shrubbs' (then more often choking the ground than now), which are to be fagoted as good fuel for baking and brewing.

'Do not plough in rainy weather, for it impoverisheth the earth.'

March and April. Take up colts from grass to be broken. Sow beans, peas, and oats. In these months are all grounds where cattle went in the last winter to be furthed (apparently managed) and cleared and the mole-hills scattered, that the fresh spring of grass may grow better. All hedges and ditches to be made betwixt ' severals', evidently enclosures as distinguished from common fields. From March 25 to May I summer pastures are to be spared, that they may have time to get head before summer cattle be put in. In the meantime such cattle are to be bestowed in meadows till May Day, and after that date such meadows are to be cleansed and spared until the crops of hay be taken off. From now till midsummer sell fat cattle and sheep, and with the money buy lean cattle and sheep. Sow barley.

May and June. Sort all cattle for their summer pasture on May Day, viz. draught oxen by themselves, milch cows by themselves, weaning calves, yearlings, two-year-olds, three-

1 Farming Calendar, from an original MS., printed in Archaeologia, xiii. 373 et seq. 
and four-year-olds, every sort by themselves, which being divided in pasture fitting for them will make larger and fairer cattle. Separate the horses in the same way. Wash sheep and shear four or five days after, which done the wool is to be well wound and weighed, and safely laid up in some place where there is not too much air or it will lose weight, nor where it is damp or it will increase too much in weight. Cleanse winter corn from thistles and weeds.

July and August. First of all comes hay-making. In August wean lambs, and put them in good pasture, and in winter put them in fresh pasture until spring, and then put them with the 'holding' sheep.

In these months is corn to be 'shornne or mowen downe' (the writer, it is to be noticed, has no preference for either method); and after the corn is carried put draught horses and oxen into the averish (corn stubble), to ease other pastures; and after them put hogs in. Gather crabs in woods and hedgerows for making verjuice.

September and October. Have all plows and harrows neat and fit for sowing of wheat, rye, mesling (wheat and rye mixed), and vetches. ${ }^{1}$ Pick hops. Buy store cattle, both steers and heifers, of three or four years old, which being well wintered at grass, or on straw at the barn doors, will be the sooner fed the summer following, and they will sooner feed after straw than grass.

From October to May are calves to be reared, because then they be more hardly bred and become the stronger cattle. Feed brawns, bacons, lards, and porkets on mast if there is any, if not on corn. 'In these months cleanse poundes or pools,

${ }^{1}$ Cf. Tusser :

'October for wheat-sowing calleth as fast '; and

'When wheat upon eddish (stubble), ye mind to bestowe

Let that be the first of the wheat ye do sowe'; and

'Who soweth in raine, he shall reap it with tears'. 
this season being the driest ;' an extraordinary assertion, unless the climate has changed, seeing that according to the monthly averages from I84I-I906, taken at the Royal Observatory, Greenwich, October is the wettest month in the year.'

November and December. Sort all kinds of sheep until Lady Day, viz. wethers by themselves, and weaning lambs by themselves; and do not put rams to the ewes before S.Lukestide, October I8, for those lambs fall about March 25, and if they fall before then the scarcity of grass and the cold will so nip and chill them that they will die or be weaklings. It is good at this time to take draught cattle and horses from grass into the house before any great storms begin. Thrash corn now after it hath had a good sweat in the mow, and so dried again, and give the straw to the draught oxen and cattle at the standaxe or at the barn doors for sparing of hay, advice which Tusser also gives :

'Serve rie straw out first, then wheat straw and peas, Then ote straw and barley, then hay if ye please.'

1 The writer of the diary probably meant this work should be done in September. 


\section{CHAPTER XII}

THE GREAT AGRICULTURAL WRITERS OF THE SEVENTEENTH CENTURY.-FRUIT GROWING.

\section{A SEVENTEENTH-CENTURY ORCHARD}

THE seventeenth century is distinguished by a number of agricultural writers whose works, as they afford the best account of the farming of the time, we may be pardoned for freely quoting. The best known of them were, Sir John Norden, Gervase Markham, Sir Richard Weston, Blythe, Hartlib, Sir Hugh Plat, John Evelyn, John Worlidge, and Houghton.

Sir John Norden printed his Surveyor's Dialogue in I608, which is in the form of a conversation between a farmer and a surveyor, the former at the outset telling the latter that men of his profession were then very unpopular because 'you pry into men's titles and estates, and oftentimes you are the cause that men lose their land, and customs are altered, broken, and sometimes perverted by your means. And above all, you look into the values of men's lands, wherefore the lords of manors do reckon their tenants to a higher rent, and therefore not only I but many poore tenants have good cause to speak against the profession'.

The surveyor attributes the increase in prices to farmers outbidding one another for farms, for the rents of farms and prices grow together; a statement which seems to have been quite true and disposes of the assertion that the landlords raised the rents unfairly, for they were quite entitled to what rent they could get in the open market, the farmers being presumably wise enough not to offer rents which would preclude a profit. He further blames the farmer of his day for being' discontented with his lot: in former times 'farmers

1 Surveyor's Dialogue (ed. 1608), p. 2. 
and their wives were content with mean dyet and base attire and held their children to some austere government, without haunting alehouses, taverns, dice, and cards; now the husbandman will be equal to the yeoman, the yeoman to the gentleman, the gentleman to the squire, and there is at this day thirty times as much vainely spent in a family of like multitude and quality as was in former ages' ; a complaint that has been common in all ages. Contrary to what is the practice to-day, and apparently to common sense, the surveyor recommends that open drains be made as narrow above as at the bottom, at the most not more than a foot and a half broad. ${ }^{1}$ Hops, he says, were then grown in Suffolk, Essex, and Surrey, 'in your loose and spongie grounds, trenched.' 'Carret' roots were raised in Suffolk and Essex, and beginning to increase in all parts of the realm ${ }^{2}$; but if he alludes to their cultivation in the open field the statement must be taken with considerable qualification, as they were not so grown generally until the end of the eighteenth century or the beginning of the next.

Kent was then, as now, the great fruit county of England; 'above all others I think the Kentishmen be most apt and industrious in planting orchards with pippins and cherries, especially near the Thames about Feversham and Sittingbourne.' But Devon and Hereford were also famous; Westcote about I630 says the Devonshire men had of late much enlarged their orchards, and 'are very curious in planting and grafting all kinds of fruit' 3 ; and John Beale in 1656 tells us Hereford ' is reputed the orchard of England '4 ; while Hartlib says there were many orchards in Worcestershire and Gloucestershire. He calls 'Tandeane' near Taunton the Paradise of England, where the husbandry was excellent, the land fruitful by nature and improved by the art and industry of the farmers; 'they
1 Surveyor's Dialogue, p. 188.
3 Victoria County History: Devon, Agriculture.
4 Herefordshire Orchards a Pattern for All England (ed. 1724).
s See infra, p. 136 .


take extraordinary pains in soyling, ploughing, and dressing their lands, and after the plow there goeth some three or four with mattocks to break the clods and to draw up the earth out of the furrows that the lands may lye round, and that the water annoy not the seed (the water evidently often lying long in the furrows between the great high ridges), and to that end they most carefully cut gutters and trenches in all places. And for the better enriching of their ploughing lands they cut up, cast, and carry in the unplowed headlands and places of no use. Their hearts, hands, eyes, and all their powers concurre in one to force the earth to yield her utmost fruit'; and the crops of wheat that rewarded this industry were sometimes 8 and ro quarters to an acre.

A short pamphlet called the Fruiterer's Secrets, published in London in 1604, imparts some interesting and curious information about fruit growing. ${ }^{1}$ There were then four sorts of cherries in England, Flemish, ${ }^{2}$ English, Gascoyne, and black, and the preserving of them from birds, always a burden on the grower, the author says can be done by a gun or a sling; the worst enemies being jays and bullfinches, who ate stones and all. Stone fruit should be gathered in dry weather, and after the dew is off, for if gathered wet it loses colour and becomes mildewed. If nettles newly gathered are laid at the bottom of the basket and on the top of the fruit, they will hasten the ripening of fruit picked unripe, and make it keep its colour.

Those English farmers who still shake their apples from the trees to fall and be bruised on the ground had better listen to the careful directions for placing the ladder on the trees where it will do no damage, as to the use of the gathering hook so that the branches can be brought within easy reach of the picker on his ladder, the wearing of a gathering apron, and the emptying of it gently into the baskets. Green fern has the same effect on pears packed for carriage as nettles on stone

1 These extracts are from the original edition in the Bodieian Library.

2 'The Flanders cherry excels', says Worlidge, Syst. Agr., p. 97.

CURTLER

K 
fruit; while apples should be packed in wheat, or better still in rye straw. For long journeys the American system of packing in barrels is anticipated, the apples being carefully put in by hand, and the barrels lined at both ends with straw, but not at the sides to avoid heating, while holes should be bored at either end to prevent heat. Pippins, John Apples, Pearmains, and other ' keepers' need not be turned until the week before Christmas, and again at the end of March, when they must be turned oftener; but never touch fruit during a frost or a thaw, or in rainy weather, or it will turn black.

Hartlib, a few years after, reckoned no less than 500 sorts of apples in England, though doubtless many of these were identical, since the same apple often has two or three names in one parish. The best for the table were the Jennetings, Harvey Apple, Golden Pippin, Summer and Winter Pearmains, John Apple, \&c.; for cider the Red Streak (the great favourite), Jennet Moyle, Eliot, Stocking Apple, \&c. He was told that in Herefordshire a tenant bought the farm he rented with the fruit crop of one year; $£$ Io to $£_{1} 5$ having been given per acre for cherries and more for apples and pears. Pears for the table were the Windsor, 'Burgamet,' 'Boon Christians'! Greenfield, and others; and for perry, which John Beale, a wellknown writer of the day considered 'a weak drink, fit for our hindes and generally refused by our gentry as breeding wind in the stomack', the Horse Pear, Bosbury, Choak, \&c. ${ }^{1}$ There were many kinds of plums, among them the Mistle Plum, Damazene, Violet, and Premorden.

Four kinds of grafting were practised: in the cleft, and in the bark, the two most usual ways ; shoulder or whip grafting, and grafting by approach, ${ }^{2}$ the last 'where the stock you intend to graft on and the tree from which you take your graft stand so near together that they may be joined, then

1 Bradley, in 1726 , gives a long list of pears all with French names, hardly any of which are now known in England.

${ }^{2}$ Worlidge, Systema Agriculturae, p. $10 \%$. 
take the sprig you intend to graft and pare away about three inches in length of the rind and wood near unto the very pith, and cut also the stock on which you intend to graft the same after the same manner that they may evenly join each other, and so bind them and cover them with clay or wax.' Inoculation was also practised, 'when the sap is at the fullest in the summer, the buds you intend to inoculate being not too young but sufficiently grown.' For transplanting the middle of October is recommended, and the wise advice added, 'plant not too deep,' and in clay plant as near the surface as possible, for the roots will seek their way downward but rarely upward; and in transplanting 'you may prune the branches as well as the roots of apples and pears, but not of plums.' The best distance apart in an orchard for apples and pears was considered to be from 20 to 30 feet, the further apart the more they benefit from the sun and air, a piece of advice which many a subsequent planter has neglected. For cherries and plums I 5 to 20 feet was thought right. Worlidge's directions for pruning are minute and careful, and should be well hammered into many slovenly farmers to-day.

Cider-making was performed much as it is in old-fashioned farms to-day, by mashing the apples in a trough by means of a millstone set edgeways, and then pressing the juice out through hair mats, the juice, says Hartlib, 'having been let stand a day or two and the black scum that ariseth in that time taken off they tunne it, and in the barrels it continueth to work some days longer, just as beer useth to do. ${ }^{1}$ Another method was to put the fruit in a clean vessel or trough, and bruise or crush it with beetles, then put the crushed fruit in a bag of haircloth and press it. ${ }^{2}$ After the cider was in the barrels there was placed in them a linen bag containing cloves, mace, cinnamon, ginger, and lemon peel which was said to make the cider taste as pleasantly as Rhenish wine.

1 Annotation upon the Legacie of Husbandry, 1651, p. 105.

2 Markham, i. 174 (ed. 1635). 
Worlidge gives us what is perhaps the first mention of a poultry farm, and strangely enough it seems to have paid. 'I have been credibly informed that a good farm hath been wholly stocked with poultry, spending the whole crop upon them and keeping severall to attend them, and that it hath redounded to a very considerable improvement '.1 Incubators of a very rude sort were used, three or four dozen eggs being placed in a 'lamp furnace made of a few boards', and hatched by the heat of a lamp or candle.

It must strike the reader that the accusation levelled against the English farmer, of having made little progress in his art from the Middle Ages to the commencement of the reign of George III is hardly warranted. Their knowledge and skill in their business were evidently such as to make considerable progress inevitable, and then as now they were in some cases assisted by their landlords, as in Herefordshire, where Lord Scudamore, after the assassination of his friend the Duke of Buckingham, devoted his energies to the culture of fruit, and with other public-spirited gentlemen turned that county into 'one entire orchard', besides improving the pastures and woods"; though Hartlib laments that gentlemen try so few experiments for the advancement of agriculture, and that both landowners and farmers instead of communicating their knowledge to each other kept it jealously to themselves. ${ }^{3}$ The chief hindrance to landlord and tenant was that the heavy hand of ancient custom lay upon them, with its antiquated communistic system of farming, which still in the greater part of the land of England utterly prevented good husbandry and stifled individual effort. It was one of these Herefordshire gentlemen, Rowland Vaughan, who in 1610 wrote what is probably the first account of irrigation in England, though the art was mentioned by Fitzherbert and must have been known in Devon and Hampshire long before his time; indeed, it is

1 Systema Agriculturae, p. 152.

${ }^{3}$ Compleat Husbandman (ed. 1659), p. 75.

2 Evelyn, Pomona (ed. 1664), p. 2. 
another instance of the then isolation of country districts that he speaks as if he had made a new discovery. He tells us that 'having sojourned two years in his father's house, wearied in doing nothing and fearing his fortunes had been overthrown, he cast about what was best to be done to retrieve his reputation'. And one day he saw from a mole-hill on the side of a brook on his property a little stream of water issuing down the working of the mole, which made the ground 'pleasing green', and from this he was led on to what he calls 'the drowning of his lands'. This was so successful that he improved the value of his estate from $£ 40$ to $£ 300$ a year, and his neighbours, who of course had first scoffed at him, came to learn from him. Not many years after 'drowning' was said to have become one of the most universal and advantageous improvements in England. ${ }^{1}$ Vaughan says that he had counted as many as 300 persons gleaning in one field after harvest, and that in the mountains near eggs were 20 a penny, and a good bullock $26 s$. $3 d$., but this was a backivard region. ${ }^{2}$

Between 1617 and 1621 the price of wheat fell from $43 s .3 d$. to $21 s$. a quarter, and immediately affected the payment of rent. ${ }^{3}$ Mr. John Chamberlain, in February, 1620, wrote to Sir Dudley Carleton, 'We are here in a strange state to complain of plenty, but so it is that corn beareth so low a price that farmers are very backward to pay their rents and in many places plead disability: for remedy whereof the Council have written letters into every shire to provide a granary with a stock to buy corn and keep it for a dear year.' Sir Symonds D'Ewes notes in his diary that 'at this time (162I) the rates of all sorts of corn were so extremely low as it made the very prices of land fall from twenty years' purchase to sixteen or seventeen. For the best wheat was sold for $2 s .8 d$. and $2 s .6 d$. the bushel, the ordinary at $2 s$. Barley and rye at $1 s .4 d$. and $1 s .3 d$. the

1 Most Approved and Long Experienced Waterworks. London, I6Io.

2 See Worlidge, Systema Agriculturae (ed. I669), p. 155.

3 Tooke, History of Prices, i. 23. 
bushel, and the worser of those grains at a meaner rate, the poorer sort that would have been glad but a few years before of coarse rye bread, did now usually traverse the markets to find out the finer wheats as if nothing else would please their palates'. Instead of being glad that they were for once having a small share of the good things of this world, he rejoices that their unthankfulness and daintiness was soon punished by high prices and dearness of all sorts of grain. ${ }^{1}$ The year I 630 was the commencement of a series of dear seasons, when for nine consecutive years the price of wheat did not fall below 40 s. a quarter and actually touched $86 \mathrm{~s}$. The restraints laid on corn-dealers had, since the principles of commerce were being better understood, been modified in 1624 , but the high prices revived the old hatred against them, and we find Sir John Wingfield writing from Rutland that he has 'taken order that ingrossers of corne shall be carefullie seen unto and that there is no Badger (corn-dealer) licensed to carry corne out of this countrye nor any starch made of any kind of graine'. He adds that he had 'refrayned the maulsters from excessive making of mault, and had suppressed 20 alehouses'.2 However, the senseless policy of preventing trade in corn received a severe blow from the statute I 5 Car. II, c. 7, which enacted that when corn was under $48 s$. persons were to be allowed to buy and store corn and sell the same again without penalty, provided they did not sell it in the same market within three months of buying it, a statute which Adam Smith said contributed more to the progress of agriculture than any previous law in the statute book.

Gervase Markham, who was born about ${ }^{3} 568$ and died in 1637 , gives us a description of the day's work of the English farmer. He is to rise at four in the morning, feed his cattle and clean his stable. While they are feeding he is to get his harness ready, which will take him two hours. Then he is to

2 Calendar of State Papers, Domestic, 1629-31, p. 414. 
have his breakfast, for which half an hour is allowed. Getting the harness on his horses or cattle, he is to start by seven to his work and keep at it till between two and three in the afternoon. Then he shall bring his team home, clean them and give them their food, dine himself, and at four go back to his cattle and give them more fodder, and getting into his barn make ready their food for next day, not forgetting to see them again before going to his own supper at six. After supper he is to mend shoes by the fireside for himself and his family, or beat and knock hemp and flax, or pitch and stamp apples or crabs for cider or verjuice, or else grind malt, pick candle-rushes, or 'do some husbandry office within doors till it befall eight o'clock'. Then he shall take his lantern, visit his cattle once more, and go with all his household to rest. The farm roller of this time, according to Markham, was made of a round piece of wood 30 inches in circumference, 6 feet long, having at each end a strong pin of iron to which shafts were made fast. ${ }^{1}$ He mentions wooden and iron harrows, but this refers only to the tines, the wooden ones being made of ash. From an illustration of a harrow which he gives, it appears it was much like Fitzherbert's and many used to-day: a wooden frame, with the teeth set perhaps more closely than ours; the single harrow 4 feet square drawn by one horse, the double harrow 7 feet square by two oxen at least. Wheat he says, when the land is dug ${ }_{5} 5$ inches deep, and the seed dibbled in, will produce twelve times as much as when ploughed; but he admits the 'intricacy and trouble' of this method. ${ }^{2}$ As to the question of mowing or reaping corn, he is of opinion that though ' it is a custom in many countries of this kingdom not to sheare the wheat but to mow it, in my conceit it is not so good, for it both maketh the wheate foule and full of weede'. Barley, however, should be mown close to the ground, though many reap it; oats too were to be mown. His directions for planting an orchard ${ }^{3}$ are interesting, both as showing the kinds

1 Whole Art of Husbandry (ed. 1635), i. 50.

${ }^{2}$ Ibid. i. roo.

3 Ibid. i. I2I. 
of fruit then grown, the number of different sorts planted together, and the growth of the olive in England. ${ }^{1}$ The orchard, he says, should be a square, divided into four quarters by alleys, and in the first quarter should be apples of all sorts, in the second pears and wardens of all sorts, in the third quinces and chestnuts, in the fourth medlars and services. A wall is the best fence, and on the north wall, 'against which the sunne reflects, you shall plant the abricot, verdochio, peache, and damaske plumbe; against the east side the white muskadine grape, the pescod plumbe, and the Emperiale plumbe; against the west, the grafted cherries and the olive tree; and against the south side the almond and the figge tree.' As if this extraordinary mixture were not enough, 'round about the skirts of the alleys' were to be planted plums, damsons, cherries, filberts and nuts of all sorts, and the 'horse clog' and 'bulleye', the two latter being inferior wild plums. Plums were to be 5 feet apart; apples and other large fruit 12 feet.

Young trees should be watered morning and evening in dry summers, and old ones should have the earth dug away from the upper part of the roots from November to March, then the earth, mixed with dung or soap ashes, replaced. Moss was carefully to be scraped off the trees with the back of an old knife, and, to prevent it, the trees manured with swine's dung. Minute distinctions are given as to pruning and washing the trees with strong brine of water and salt, either with a garden pump placed in a tub or with 'squirtes which have many hoales', the forerunner of modern spraying.

Cider was then mostly made in the west, as in Devonshire and Cornwall, and perry in Worcestershire and Gloucestershire ; but he leaves out Herefordshire, where it was certainly made at this time. ${ }^{2}$

A curious help to fattening beasts, says Markham, is a lean horse or two kept with them, for the beasts delight to feed

1 An astonishing statement; cf. Denton, England in the Fifteenth Cen. tury; p. 56, Neckham, De Natura Rerum, cap. clxvi. and above, p. 93.

${ }^{2}$ IVhole Ant of Husbandry (ed. 1635), i. 173. 
with them. Fattening cattle were to have first bite at the pastures, then draught cattle, and then sheep; after Midsummer, when there is an extraordinary sweetness in the grass, suffer the cattle to eat the grass closer till Lammas (August 1). Though some do not hold with him, he thinks reading and writing not unprofitable to a husbandman, but not much material 'to his bailiff'; for there is more trust in an honest score chalked on a trencher than 'in a commen writen scrowle'. Landowners derived a good income from their woods and coppices. An acre of underwood of twenty-one years' growth, was at this time worth from $£ 20$ to $£ 30$; of twelve years' growth, $£ 5$ to $£ 6$; but on many of the best lands it was only cut every thirty years. ${ }^{1}$

In $1742-3$ oak timber was worth from $15 d$. to $18 d$. per cubic foot and ash about $10 d$. During the Napoleonic war oak sold for $4 s .6 d$. a foot.

In Blyth's Improver Improved we have one of the first accounts of covered drains. The draining trench was to be made deep enough to go the bottom of the 'cold spewing moist water' that feeds the flags and the rushes; as for the width ' use thine own liberty', but be sure make it as straight as possible. The bottom was to be filled in with faggots or stones to a depth of 15 inches, a method in some parts retained till comparatively modern times, with the top turf laid upon them grass downward, and the drain filled in with the earth dug out of it.

A country gentleman at this date could keep up a good establishment on an income which to-day would compel him to live economically in a cottage. From the accounts of Mr. Master, a landowner near Chiselhurst, it appears that a man with an income of $£_{300}$ or $£ 400$ a year could live in some luxury, keep a stud of horses, and a considerable number of servants. ${ }^{2}$ Some of them had no scruples about adding to

${ }^{1}$ Whole Art of Husbandry (ed. 1635), ii. 144, and MS. accounts of Mr. Chevallier of Aspall Hall, Suffolk.

${ }_{2}$ Thorold Rogers, History of Agriculture and Prices, v. 28. 
their incomes by turning corn-dealers, even selling such small quantities as pecks of peas, bushels of rye, and half pecks of oatmeal. From the accounts of one of them, Henry Best, ${ }^{1}$ of Elmswell, we learn many valuable details concerning farming in Yorkshire about 164I. It was the custom to put the ram to the ewes about October 18 , but Best did so about Michaelmas, and generally used one ram to 30 or 40 ewes, and he considered it necessary that the ewes should be two-shear. 'Good handsome ewes', he says, could have been bought at Kilham fair for $3 s$. $6 d$. each, a price far below the average of the time. As for wages, mowers of grass had Iod. a day, and found their own food and their scythes, which cost them about 2s. $3 d$. each. Haymakers got $4 d$. a day, and had to 'meat themselves' and find their own forks and rakes. Shearers or reapers were paid from $8 d$. to Iod., and found their own sickles; binders and stackers, $8 d$.; mowers of 'haver', or oats, lod., a good mower cutting 4 acres a day. In $164 \mathrm{r}$ he sold oats for $14 \mathrm{~s}$. a quarter, best barley for $22 s$., rye $27 s$. $6 d$., wheat $30 s^{2}{ }^{2}$ The roads were dreadful, and produce nearly all sent to market on pack-horses. 'Wee seldome send fewer than 8 horse loads to the market at a time, and with them two men, for one man cannot guide the poakes (sacks) of above four horses. When wee sende oats to the market wee sack them up in 3 bushel poakes and lay 6 bushels on a horse ; when wee sende wheate, rye, or masseldene (rye and wheat) and barley to market wee put it into mette poakes ( 2 bushel sacks), sometimes into half quarter sacks, and these we lay on horses that are short coupled and well backed.' When the servants got to market they were charged a halfpenny a horse for stabling and hay, but if they dined at the inn they paid nothing for their horses, and their dinners cost them $4 d$. a head. Butter was sold by the lb., or the 'cake' of $2 \mathrm{lb}$., and in the beginning of Lent was $5 \mathrm{~d}$. a lb., by A pril 2o, $3 d$., in the middle of May, $2 \frac{1}{2} d$. When William Pinder

1 Farming and Account Books of Henry Best of Elmswell, 1641. Surtees Society, xxxiii. 157 .

2 Ibid. p. 99. 
took 50 acres of land 'of my Lord Haye' he paid a fine of $£ 60$ and a rent of $£ 40$; but this must have been an extremely choice piece of land, for arable land rented apparently at less than 35 . an acre. ${ }^{1}$ The rent of a cottage was usually ros. a year, "though they have not so much as a yard or any backe side belonging to them.' There is more evidence, if such were needed, of the beneficial effect of enclosure, which was said to treble the value of pasture. Good meadow land fetched a great price: 'The medow Sykes is about 5 acres of grounde, and was letten in the year 1628 at $£ 6$ per annum, and in 1635 at $£ 6$ I $3 s .4 d$.'

The requirements of a foreman on a farm were that he could sow, mow, stack peas, go well with 4 horses, and be accustomed to marketing ; and for this when hired by the year he received 5 marks, and perhaps half a crown as earnest money. The next man got $50 s$., the next $46 s$. $6 d$., the fourth $35 s$. 'Christopher Pearson had the first year he divelt here $£_{3} 5$ s. od. wages per annum and $5 s$. to a God's penny (earnest money); next year he had $£_{4}$ wages, and he was both a good seedsman,' before the invention of drills a very valuable qualification, 'and did sow all our seed both the years. When you are about to hire a servant you are to call them aside and talk privately with them concerning their wage, and if the servants stand in the churchyard they usually call them aside and walk to the back side of the church and there treat of their wage. I heard a servant asked what he could do, who made this answer:

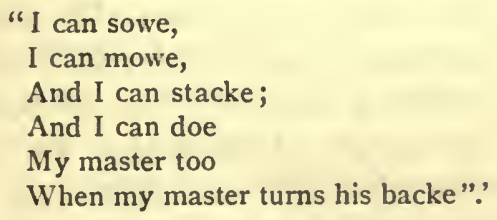

If we are to judge by the food provided for the thatchers, who

${ }^{1}$ Farming and Account Books of Henry Best of Elmswell, 1641. Surtees Society, xxxiii. 124. Many districts in the north of England were still much behind the rest of the country. 
were little better than ordinary labourers, the Yorkshire farmhand fared well on plenty of simple food, his three meals a day consisting of butter, milk, cheese, and either eggs, pies, or bacon, sometimes porridge instead of milk.

Probably, however, few country gentlemen were such industrious farmers as Best ; many of them passed their days mostly in hunting and fowling and their evenings in drinking, though we know too that there were exceptions who did not care for this rude existence. Deer hunting, and we must add deer poaching, was the great sport of the wealthy, but the smaller gentry had to be content with simpler forms of the chase. For fox hunting each squire had his own little pack, and hunted only over his own estate and those of his friends. He had also the otter, the badger, and the hare to amuse him. Fowling was conducted, as in the Middle Ages, by hawk or net, for the shot gun had not yet come into use, and was forbidden by an old law. ${ }^{1}$ The partridge and pheasant, as now, were the chief game birds. After the Restoration the country gentlemen seem to have been infected by the dissipation of the Court, and farming was left to the tenant farmer and yeoman: 'our gentry', says Pepys, 'have grown ignorant of everything in good husbandry.'

The middle of the seventeenth century was the Golden Age of the yeoman who owned and farmed his land; even at the end of the Stuart period, when their decline had already begun, Gregory King estimated their numbers at 160,000 families, or about one-seventh of the population. The class included all those between the man who owned freehold land worth 40 s. a year and the wealthier yeoman who was hardly distinguishable from the small gentleman. Owning their own land they were a sturdy and independent class, and they 'took a jolly pride in voting as in fighting on the opposite side of the neighbouring

1 Trevelyan, England under the Stuarts, $8 \mathrm{sq}$. Though, as we have seen, p. I 57, the writer of the Fruiterer's Secrets recommends the gun for scaring birds in 1604 . 
squire'. 'The yeomanry', wrote Fuller, 'is an estate of people almost peculiar to England;' he 'wears russet clothes but makes golden payment, having tin in his buttons and silver in his pocket. He seldom goes abroad, and his credit stretches farther than his travel.' The tenant farmers were nearly as numerous, King estimating them at 150,000 families; economically they were about on a level with the yeoman, their social standing, however, was considerably inferior.

The greatest improvement of the seventeenth century, the introduction from Holland of turnips and clover, was overestimated by its author, Sir Richard Weston; for he tells his sons that by sowing flax, turnips, and clover they might in five years improve 500 acres of poor land so as to bring in $£ 7,000$ a year. ${ }^{1}$ To bring about this desirable consummation, he provides his sons with accounts as to the cost, one of which shows the cost of growing an acre of flax and the profit thereon, though this gentleman's estimates are clearly optimistic:

\section{DR.}

Devonshiring, i.e. paring and burning . . . I $\circ \circ$

Lime .

Ploughing and harrowing .

3 bushels of seed

Weeding

Pulling and binding

Grassing the seed from the flax .

Watering, drying, swinging, and beating

CR.

900 lb. of flax

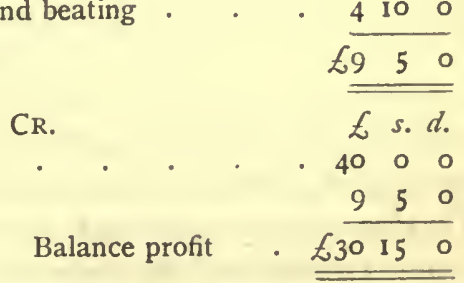

Turnips were to come after flax, and were to be given to the cows as they did in Flanders; that is, wash them clean, put them in a trough where they were to be stamped together

1 The Husbandrie of Brabant and Flanders (ed. 1652), p. 18. 
with a spitter or small spade; and the turnips were to be followed by clover. All these, says Weston, were already grown in England, but 'there is as much difference between what groweth here and there as is between the same thing which groweth in a garden and that which groweth wild in the fields'. Worlidge soon after recommended that clover be sown on barley or oats about the end of March or in April, and harrowed in, or by itself; and says, with optimism equal to Weston's, one acre of clover will feed you as many cows as 6 acres of ordinary grass and make the milk richer. ${ }^{1}$

It has been noticed that the price of wool altered little during the century, and from the private accounts of Sir Abel Barker ${ }^{2}$ of Hambleton, in the County of Rutland, we learn that in 1642 he sold his wool to his 'loving friend Mr. William Gladstone' for $£ \mathrm{I}$ a tod, though by 1648 it had gone up to $29 s$., a good price for those days. During the Civil War some of Barker's horses were carried off for the service of the State, and he values them at $£ 8$ a piece, a fair price then. Some years later, for mowing 44 acres of grass he sets down in his account $£_{2} 75 . \circ d$., for making the same $£_{2} 3^{s . o d ., ~ a n d ~}$ stacking it 3 s.

Simon Hartlib, a Dutchman by birth and a friend of John Milton, published his Legacy in $165 \mathrm{I}$, containing both rash statements and useful information. We certainly cannot believe him when he states that pasture employs more hands than tillage. His estimate of a good crop of wheat was from I 2 to 16 bushels per acre, and he speaks strongly of the great fluctuations in prices, for he had known barley sell at Northampton at $6 d$. a bushel, and within 12 months at 5 s., and wheat in London in one year varied from $3 s .6 d$. to $15 s$. a bushel. The enormous number of dovecotes was still a great nuisance, and the pigeons were reckoned to eat $6,000,000$ quarters of grain

1 Systema Agriculturae, p. 26.

2 MS. accounts of Sir Abel Barker, in the possession of G. W. P. Conant, Esq. 
annually. Hartlib recommends his countrymen to sow 'a seed commonly called Saint Foine, which in England is as much as to say Holy Hay,' as they do in France : especially on barren lands, advice which some of them followed, and in Wilts., soon after, sainfoin is said to have so improved poor land that from a noble $(6 s .8 d$.) per acre, the rent had increased to $30 .^{1}$ They were also to use 'another sort of fodder which they call La Lucern at Paris for dry and barren grounds'. So wasteful were they of labour in some parts that in Kent were to be seen $I 2$ horses and oxen drawing one plough. ${ }^{2}$

The use of the spade was long looked askance at by English liusbandmen; old men in Surrey had told Hartlib that they knew the first gardeners that came into those parts to plant cabbages and 'colleflowers', and to sow turnips, carrots, and parsnips, and that they gave $£ 8$ an acre for their land. The latter statement must be an exaggeration, as it is equivalent to a rent of about $£ 40$ in our money; but we may give some credence to him when he says that the owner was anxious lest the spade should spoil his ground, 'so ignorant were we of gardening in those days.' Though it was not the case in Elizabeth's time, by now the licorice, saffron, cherries, apples, pears, hops, and cabbages of England were the best in the world; but many things were deficient, for instance, many onions came from Flanders and Spain, madder from Zealand, and roses from France. ${ }^{3}$ 'It is a great deficiency in England that we have not more orchards planted. It is true that in Kent, and about London, and in Gloucestershire, Herefordshire, and Worcestershire ${ }^{4}$ there are many gallant orchards, but in other country places they are very rare and thin. I know in Kent some advance their ground from $5 s$. per acre to $£ 5$ by this means', and 30 acres of cherries near Sittingbourne had realized $€ \mathbf{I}, 000$ in one year. His recipe for making old fruit

1 Worlidge, Systema Agriculturae, p. 28.

2 Compleat Husbandman (1659), p. 5.

s Ibid. p. 9 .

${ }^{4}$ Cf. supra, p. 136. 
trees bear well savours of a time when old women were still burnt as witches." 'First split his root, then apply a compost of pigeon's dung, lees of wine, or stale wine, and a little brimstone'. The tithes of wine in Gloucestershire were ' in divers parishes considerably great', and wine was then made in Kent and Surrey, notably by Sir Peter Ricard, who made 6 or 8 hogsheads yearly. ${ }^{1}$ There is no doubt that the vine has been grown in the open in England from very early times until coinparatively recent ones. The Britons were taught to plant it by the Romans in A.D. $280 .^{2}$ In Domesday there are 38 examples of vineyards, chiefly in the south central counties. Neckham, who wrote in the twelfth century, says the vineyard was an important adjunct to the mediaeval mansion. ${ }^{3}$ William of Malmesbury praised the vines and wine of Gloucestershire; and says that the vine was either allowed to trail on the ground, or trained to small stakes fixed to each plant. Indeed, the mention of them in mediaeval chronicles is frequent.

Two bushels of green grapes in 1332 fetched $75.6 d .^{4}$ Richard II planted vines in great plenty, according to Stow, within the upper park of Windsor, and sold some part to his people. The wine made in England was sweetened with honey, and probably flavoured and coloured with blackberries. ${ }^{5}$ At the dissolution of the monasteries there was a vineyard at Barking Nunnery. 'We might have a reasonable good wine growing in many places of this realme', says Barnaby Googe, about I577, 'as doubtless we had immediately after the Conquest, tyll, partly by slothfulnesse, partly by civil discord long continued, it was left, and so with time lost. . . . There is besides Nottingham an ancient house called Chylwel in which remaineth yet as an ancient monument in a great wyndowe of glasse, the whole order of planting, proyning, stamping, and pressing of vines. Upon many cliffes and hills are

1 Compleat Husbandman (1659), p. 23.

2 Archaeologia, i. 324 ; iii. 53.

3 De Natura Rerum, Rolls Ser., lxi.

4 Denton, England in the Fifteenth Century, $57 \mathrm{n}$. 5 Ibid. 
yet to be seen the rootes and old remaines of vines.' Plot, in his Natural History of Staffordshire, ' says 'the vine has been improved by Sir Henry Lyttelton at Over (Upper) Arley, which is situate low and warm, so that he has made wine there undistinguishable from the best French by-the most judicious palates, but this I suppose was done only in some over hot summer, and Dr. Bathurst made very good claret at Oxon in I 685 , a very mean year for the purpose.' In I 720 the famous vineyard at Bath of 6 acres, planted with the 'white muscadene and the 'black Chester grape,' produced 66 hogsheads of wine worth $£$ IO a hogshead, but in unfavourable years grew very little.' ${ }^{2}$ Mr. Peter Collinson, writing from Middlesex in 1747, says, 'the vineyards turn to good profit, much wine being made this year in England ;' and again in 1748 , 'my vineyards are very ripe; a considerable quantity of wine will this year be made in England.' ${ }^{3}$ However, the attempt made to grow vines on the undercliff at Ventnor at the end of the eighteenth century by Sir Richard Worsley ended in dismal failure, and it is probable that the English climate in its normal years seldom produced good grapes out of doors whatever it may have done in exceptionally hot ones, unless we assume that it has changed considerably, for which there is little ground.

Hartlib was no friend of commons; they made the poor idle and trained them for the gallows or beggary, and there were fewest poor where there were fewest commons, ${ }^{4}$ as in Kenta statement re-echoed by many observant writers; he also recommends enclosures, because they gave warmth and consequent fertility to the soil. He tells us that an effort had been

1 Ed. 1686, p. 380.

2 R. Bradley, A General Treatise of Husbandry (ed. 1726), ii. 52.

3 Tooke, History of Prices, i. 44. Brandy was made in the eighteenth century from grapes grown in the Beaulieu vineyards in Hampshire, and a bottle of it long kept at the abbey.-Hampshire Notes and Queries, vi. 62. There are two vineyards to-day, of $2_{4}^{\frac{3}{4}}$ and 4 acres respectively, on the estates of the Marquis of Bute in Glamorganshire ; but a vintage is only obtained once in four or five years from them, and they are not profitable.

Compleat Husbandman, 1659, p. 42.

CYRTLER 
made by James I to encourage the growth of mulberry trees and the breeding of silkworms, the lords-lieutenant of the different counties being urged to see to it, but it had little effect. ${ }^{1}$

The number of different sorts of wheat was by this time considerable. Hartlib gives the white, red, bearded ("which is not subject to mildews as others'); some sorts with two rows, others with four and six; some with one ear on a stalk, others with two; the red stalk wheat of Bucks; winter wheat and summer wheat. There were also twenty varieties of peas that he knew, and the white, black, naked, Scotch, and Poland oats. Markham adds the whole straw wheat, the great brown pollard, the white pollard, the organ, the flaxen, and the chilter wheat.

There was a sad lack of enterprise in the breeding of stock now and for many generations before ; indeed, it may be doubted if this important branch of farming, except perhaps in the case of sheep, was much attended to until the time of Bakewell and the Collings. In Elizabeth's time a Frenchman had twitted England with having only 3,000 or 4,000 horses worth anything, which was one of the reasons that induced the Spaniards to invade us. ${ }^{2}$ 'We are negligent, too, in our kine, that we advance not the best species.'

The size of cattle at this date, however, seems to have been greater than is often stated. The Report of the Select Committee on the Cultivation of Waste Lands in 1795 , states that the average weight, dressed, of cattle at Smithfield in 1710 was only $370 \mathrm{lb} .{ }^{3}$ yet the Household Book of Prince Henry at the commencement of the seventeenth century says that an ox should weigh $600 \mathrm{lb}$. the four quarters, and cost about $£ 9$ IOs., a sheep about $45 \mathrm{lb}$,, so that the latter were apparently relatively smaller than the oxen. In 1603 oxen were sold at

- In this apparently repeating Davenant's statement. See M०Culloch, Commercial Dictionary, 1852, p. 271. 
Tostock in Suffolk weighing $I, 000$ lb. apiece, dead weight. ${ }^{1}$ According to the records of Winchester College, the oxen sold there in the middle of the century averaged, dressed, about $575 \mathrm{lb}$; in 1677,35 oxen sold there averaged $730 \mathrm{lb}$. "Some kine,' it was said at the end of the century, ' have grown to be very bulky and a great many are sold for $£$ Io or $£ \mathrm{I} 2$ apiece ; there was lately sold near Bury a beast for $£_{30}$, and 'twas fatted with cabbage leaves. An ox near Ripon weighed, dressed, $13 \frac{1}{4}$ cwt.' ${ }^{2}$ They were, of course, chiefly valued as beasts of draught, and no doubt the one Evelyn saw in 1649 , 'bred in Kent, 17 foot in length, and much higher than I. could reach,' was a powerful animal for this purpose. The young 'ones were taught to draw by yoking two of them, together with two old ones before and two behind, with a man on each side the young ones, 'to keep them in order and speak them fair,' for if much beaten they seldom did well: for the first two or three days they were worked only three or four hours a day, but soon they worked as long as the older ones, that is from 6 to II, then a bait of hay and rest till $I$, with work again till 5, at least in Lancashire. They were kept in the yoke till nine or ten years old, then turned on to the best grass in May, and sold to the butcher. ${ }^{3}$

1 Thorold Rogers, History of Agriculture and Prices, v. 332.

2 Houghton, Collections for Improvement of Husbandry, i. 294.

3 Ibid., Collections for Husbandry and Trade (ed. 1728), iv. 336. 


\section{CHAPTER XIII}

THE EVILS OF COMMON FIELDS.-HOPS.-IMPLEMENTS.MANURES.-GREGORY KING.-CORN LAWS

From what has been said in the preceding pages, it will be gathered that a vast amount of compassion has been wasted on the enclosure of commons, for it is abundantly evident from contemporary writers that there were a large number of people dragging out a miserable existence on them, by living on the produce of a cow or two, or some sheep and a few poultry, with what game they could sometimes catch, and refusing regular work. Dymock, Hartlib's contemporary, questions 'whether commons do not rather make poore by causing idlenesse than maintaine them;' and he also asks how it is that there are fewest poor where there are fewest commons.

In the common fields, too, there was continual strife and contention caused by the infinite number of trespasses that they were subject to. ${ }^{1}$ The absence of hedges, too, in these great open fields was bad for the crops, for there was nothing to mitigate drying and scorching winds, while in the open waste and meadows the live stock must have sadly needed shelter and shade, 'losing more flesh in one hot day than they gained in three cool days.' Worlidge, a Hampshire man, joins in the chorus of praise of enclosures, for they brought employment to the poor, and maintained treble 'the number of inhabitants' that the open fields did; and he gives further proof of the enclosure of land in the seventeenth century, when he mentions 'the great quantities of land that have within our memories lain open, and in common of little value, yet when enclosed have proved excellent good land.'

1 Worlidge, Systema Agriculturae (ed. 1669), p. Io. 
Why then was this most obvious improvement not more generally effected? Because there was a great impediment to it in the numerous interests and diversity of titles and claims to almost every common field and piece of waste land in England, whereby one or more envious or ignorant persons could thwart the will of the majority. ${ }^{1}$ Another hindrance, he says, was that many roads passed over the commons and wastes, which a statute was needed to stop.

In the seventeenth century hop growing was not nearly so common in England as in the preceding, when Harrison had said, in his Description of Britain, 'there are few farmers or occupiers in the country which have not gardens and hops growing of their own, and those far better than do come from Flanders.' There seems, indeed, to have been a prejudice against the hop; Worlidge ${ }^{2}$ says it was esteemed an unwholesome herb for the use it was usually put to, 'which may also be supplied with several other wholesome and better herbs.' John Evelyn was very much against them, probably because he was such an advocate of cider: 'It is little more than an age,' he says, 'since hopps transmuted our wholesome ale into beer, which doubtless much altered our constitutions. That one ingredient, by some not unworthily suspected, preserving drink indeed, and so by custom made agreeable, yet repaying the pleasure with tormenting diseases, and a shorter life, may deservedly abate our fondness for it, especially if with this be considered likewise the casualties in planting it, as seldom succeeding more than once in three years.' ${ }^{3}$ The City of London petitioned against hops as spoiling the taste of drink.

Yet its cultivation is said to have advanced the price of land to $£_{40}, £_{50}$, and sometimes $£_{100}$ an acre, the latter an almost incredible price if we consider the value of money then. There were not enough planted to serve the kingdom,

1 Ibid. p. 124. 2 Ibid. p. 124.

${ }^{3}$ Pomona (ed. 1664), p. I. 
and Flemish hops had to be imported, though not nearly so good as English. A great deal of dishonesty, moreover, was shown by the foreign importers, so that in $160_{3}$ a statute (I Jac. I, c. I8) was passed against the 'false packinge of forreine hops,' by which it appears that the sacks were filled up with leaves, stalks, powder, sand, straw, wood, and even soil, for increasing the weight, by which English growers it is said lost $£ 20,000$ a year. Such hops were to be forfeited, and birewers using them were to forfeit their value. The chief cause of their decrease was that few farmers would take the trouble and care required to grow them, in spite of the often excellent prices, which at Winchester at this date averaged from 50 s. to 80 s. a cwt., sometimes, however, reaching over 200s., as in 1665 and 1687 , though then as now they were subject to great fluctuations, and in I69I were only 3 Is. Many, too, were discouraged by the fact ' they are the most of any plant that grows subject to the various mutations of the air, mildews sometimes totally destroying them; no doubt an allusion to the aphis blight. Hop yards were often protected at this early date by hedges of tall trees, usually ash or poplar, the elm being disapproved of as contracting mildews. Markham ${ }^{1}$ says that Hertfordshire then contained as good hops as he had seen anywhere, and there the custom was 250 hills to every rood, 'and every hill will bear $2 \frac{\mathrm{T}}{2} \mathrm{lb}$., worth on an average 4 nobles a civt. (a noble $=6 s$. $8 d$.) ;' hills were to be $6 \mathrm{ft}$. apart at least, poles 16 to $18 \mathrm{ft}$. long and 9 or Io inches in circumference at the butt, of ash, oak, beech, alder, maple or willow.

Some planted the hills in 'plain squares clequerwise, which is the best way if you intend to plough with horses between the hills. Others plant them in form of a quincunx, which is better for the hop, and will do very well where your ground is but small that you may overcome it with either the breast plough or spade.' The manure recommended by Worlidge 1 Ed. 1635, Book i, p. 175 . 
was good mould, or dung and earth mixed. The hills were like mole-hills 3 feet high, and sometimes were large enough to have as many as 20 poles, so that some hop yards must have looked very different then from what they do now, even when poles are retained; but from two to five poles per hill was the more usual number. Cultivation was much the same as in Reynold Scott's time, and picking was still done on a 'floor' prepared by levelling the hills, watering, treading, and sweeping the ground, round which the pickers sat and picked into baskets, but the hop crib was also used.

It was considered better not to let the hops get too ripe, as the growers were aware of the value of a fresh, green-looking sample; and Worlidge advises the careful exclusion of leaves and stalks, though Markham does not agree with him. Kilns were of two sorts: ${ }^{1}$ the English kiln made of wood, lath, and clay; the French of brick, lime, and sand, not so liable to burn as the former and therefore better. One method of drying was finely to bed the kiln with wheat straw laid on the hair-cloth, the hops being spread 8 inches thick over this, 'and then you shall keepe a fire a little more fervent than for the drying of a kiln full of malt,' the fire not to be of wood, for that made the hops smoky and tasted the beer, but of straw! Worlidge, strangely, recommended the bed of the kiln to be covered with tin, as much better than hair-cloth, for then any sort of fuel would do as well as charcoal, since the smoke did not pass through the hops.

Besides Hertfordshire, Northamptonshire, Oxfordshire, Leicestershire, and Rutlandshire ; Lincolnshireand Cambridgeshire were recommended by Markham for hop growing, the great hop counties of to-day being passed over by him.

The growth of hemp and flax had by this time considerably decayed, owing to the want of encouragement to trade in these commodities, the lack of experience in growing them, and the tithes which in some years amounted to more than 
the profits. ${ }^{1}$ An'acre of good flax was worth from $£ 7$ to $£ 12$; but if 'wrought up fit to sell in the market' from $£ 15$ to $£ 20$.

Woad was considered a 'very rich commodity', but according to Blyth it robbed the land if long continued upon it, although if moderately used it prepared land for corn, drawing a 'different juice from what the corn requires'. It more than doubled the rent of land, and had been sold at from $£^{6}$ to $£ 20$ a ton, the produce of an acre. John Lawrence, who wrote in the first quarter of the eighteenth century, says woad was in his time cultivated by companies of people, men, women, and children, who hired the land, built huts, and grew and prepared the crop for the dyer's use, then moved on to another place. ${ }^{2}$

There were proofs that man's inventive genius was at work among farm implements. Worlidge mentions ${ }^{3}$ an engine for setting corn, invented by Gabriel Plat, made of two boards bored with wide holes 4 in. apart, set in a frame, with a funnel to each hole. It was fitted with iron pins 5 in. long to 'play up and down', and dibble holes into which the corn was to go from the funnels. This machine was so intricate and clumsy that Worlidge found no use for it. However, he recommends another instrument which certainly seems to anticipate Tull's drill, though Tull is said to have stated when Bradley showed him a cut of it that it was only a proposal and it never got farther than the cut. ${ }^{4}$ It consisted of a frame of small square pieces of timber 2 inches thick; the breadth of the frame 2 feet, the height 18 inches, length 4 feet, placed on

1 Worlidge, Systema Agriculturae, p. 38. Plot, however, in his Natural History of Staffordshire, 1686, says hemp and flax were sown in small quantities all over the county, p. Iog.

2 New System of Agriculture (ed. 1 726), p. 113. Woad is still grown ' in some districts in England ' (Morton, Cyclopaedia of Agriculture, ii. 11 59), but in the Agricultural Returns of 1907 apparently occupies too small an acreage to entitle it to a separate mention.

3 Worlidge, Systema Agriculturae, p. 43.

4 Tull, in his Horseshoeing Husbandry (p. 147), speaks of the drill as if already in use. 
four good-sized wheels. In the middle of the frame a coulter was fixed to make a furrow for the corn, which fell through a wooden pipe behind, that dropped the corn out of a hopper containing about a bushel, the fall of the corn from the hopper being regulated by a wooden wheel in its neck. The same frame might contain two coulters, pipes, and hoppers, and the instrument could be worked with one horse and one man. It was considered a great advance on sowing broadcast, and by the use of it 'you may also cover your grain with any rich compost you shall prepare for that purpose, either with pigeon dung, dry or granulated, or any other saline or lixirial (alkaline, or of potash) substance, which may drop after the corn from another hopper behind the one that drops the corn, or from a separate drill'. The corn thus sown in rows was found easier to weed and hoe, so that it is clear that this advantage was well understood before Tull's time.

There was a great diversity of ploughs at this date, almost every county having some variation. ${ }^{1}$ The principal sorts were the double-wheel plough, useful upon hard land, usually drawn with horses or oxen two abreast, the wheels 18 in. to 20 in. high. The one-wheel plough, which could be used on almost any sort of land; it was very 'light and nimble', so that it could be drawn by one horse and held by one man, and thus ploughed an acre a day.

Then there was a 'plain plough without either wheel or foot ', very easy to work and fit for any lands; a double plough worked by four horses and two men, of two kinds, one ploughing a double furrow, the other a double depth.

There were also ploughs with a harrow attached, others constructed to plough, sow, and harrow, but not of much value; and a turfing plough for burning sod. Carts and waggons were of many sorts, according to the locality, the greater wheels of the waggon being usually i 8 feet in circumference the lesser $y$ feet. A useful implement was the trenching plough

1 Worlidge, Systema Agriculturae, p. 205. 
used on grass land to cut out the sides of trenches or drains, with a long handle and beam and with a coulter or knife fixed in it and sometimes a wheel or wheels. The following is a list of other implements then considered necessary for a farm.

Harrows
Forks
Sickles
Reaphooks
Sledds

For the field.

Mole spear

Mole traps

Weedhooks

Pitchforks

Rakes
Beetles

Roller

Cradle scythe

Seedlip. ${ }^{\mathrm{I}}$

For the barn and stable.

Flails

Pannels (pillions)

Winnowing fan

Sieves

Sacks

Bins

Curry combs

Whips

Harness

Scythes

Rakes
Pack-saddles

Cart lines

Ladders

Corn measures

Brooms

Skeps (baskets)
Pails

Mane combs

Goads

Yokes

Wanteyes ${ }^{2}$

Suffingles (surcingles?)

Screens for corn.

\section{For the meadows and pastures.}

Pitchforks

Fetters and clogs

Cutting spade for hayrick

Besides many tools.

A considerable variety of manures were in use, chalk, lime, marl, fuller's earth, clay, sand, sea-weed, river-weed, oyster shells, fish, dung, ashes, soot, salt, rags, hair, malt dust, bones, horns, and the-bark of trees. Of the oyster shells Worlidge says, 'I am credibly informed that an ingenious gentleman living near the seaside laid on his lands great quantities, which made his neighbours laugh at him (as usually they do at anything besides their own clownish road or custom of ignorance), and after a year or two's exposure to the weather

1 The seedlip was a long-shaped basket suspended from the sower's shoulder and was usually made of wood.

${ }^{2}$ Horse-girths for securing pack-saddles. 
'they exceedingly enriched his land for many years after.' The bones then used were marrow-bones and fish bones, or ' whatever hath any oiliness or fatness in it', but the bones of horses and other animals were also used, burnt before being applied to the land, crushing not being thought of till many years after.

In 1688 Gregory King, ${ }^{1}$ who was much more accurate than most statisticians of his time, gave the following estimate of the land of England and Wales:-

Acres.

Per acre.

Arable

Pasture and meadow

$9,000,000$ worth to rent $5 s .6 d$.

Woods and coppices

Forests and parks .

Barren land

Houses, gardens, churches, \&c. $1,000,000$

Water and roads . . . 1,000,000

Total $\overline{39,000,000}$

He valued the live stock of England and Wales at $£ 18 \frac{1}{4}$ millions, and estimated the produce of the arable land in England at :

\begin{tabular}{|c|c|c|c|}
\hline & & $\begin{array}{l}\text { Million } \\
\text { bushels. }\end{array}$ & $\begin{array}{c}\text { Value } \\
\text { per bushe }\end{array}$ \\
\hline Wheat & . & 14 & 3s. $6 d$. \\
\hline Rye & & 10 & 2s. $6 d$. \\
\hline Barley & • & 27 & 2s. od. \\
\hline Oats. & $\cdot$ & 16 & Is. $6 d$. \\
\hline Peas. & . & 7 & $2 s .6 d$. \\
\hline Beans & 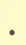 & 4 & $2 s .6 d$. \\
\hline Vetches & 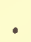 & I & $2 s . \mathrm{od}$. \\
\hline
\end{tabular}

The same statistician drew up a scheme of the income and

1 Houghton, about the same time, said England contained 28 to 29 million acres, of which 12 millions lay waste (Collections, iv. I I). In 1907 the Board of Agriculture returned the total area of England and Wales, excluding water, at $37,130,344$ acres. 
expenditure of the 'several families' in England in 1688 , the population being $5 \frac{1}{2}$ millions $^{1}$ :-

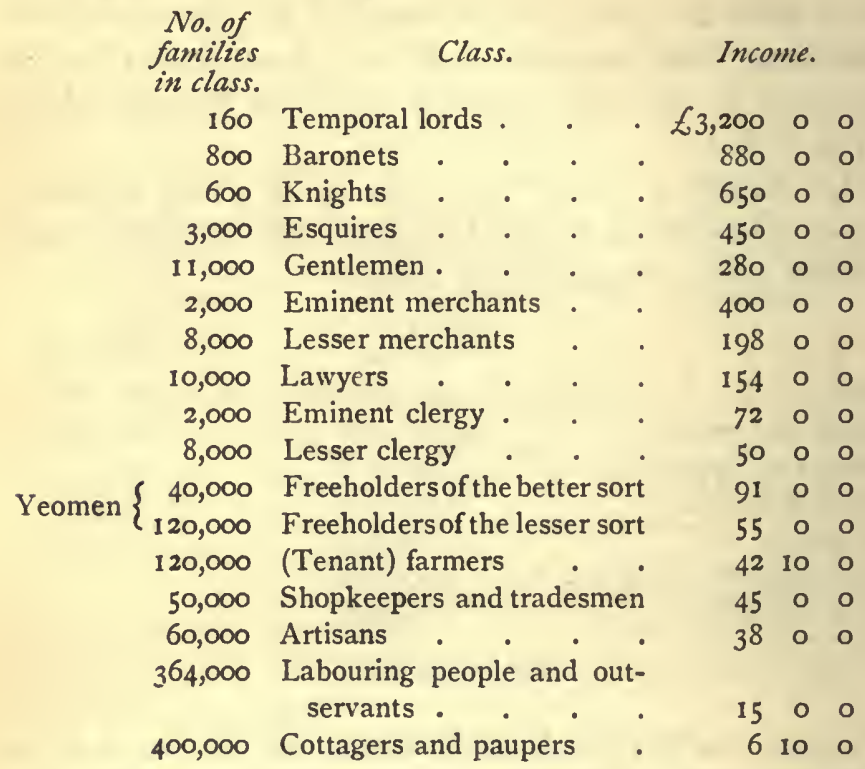

He calculated that the freeholder of the better sort saved on an average $£ 8$ I5s. Od. a year per family of 7 ; and the lesser sort $£ 2$ I 5 s. Od. a year with a family of $5 \frac{1}{2}$. The tenant farmer with a family of 5, only saved 25s. a year, while labouring families who, he said, averaged $3 \frac{1}{2}$ (certainly an under estimate), lost annually $7 s$., and cottagers and paupers with families of $3 \frac{1}{4}$ (also an under estimate) lost $16 s$. $3 d$. a year. It will thus be seen that the tenant farmers, labourers, and cottagers, the bulk of those who worked on the land, were very badly off; the tenant farmer saved considerably less than the artisan. It will also be noticed that the rural population of England was about three-quarters of the whole. ${ }^{2}$

1 Eden, State of the Poor, i. 228.

3 If we allow that most of the two last classes enumerated were country folk. For the decline of the yeoman class, see chap. xviii. 
The winter of 1683-4 was marked by one of the severest frosts that have ever visited England. Ice on the Thames is said to have been eleven inches thick; by Jan. 9 there were streets of booths on it; and by the 24 th, the frost continuing more and more severe, all sorts of shops and trades flourished on the river, 'even to a printing press, where the people and ladies took a fancy to have their names printed and the day and year set down when printed on the Thames.' Coaches plied, there was bull-baiting, horse and coach races, puppet plays and interludes, tippling 'and other lewd places'-a regular carnival on the water. ${ }^{1}$ Altogether the frost which began at Christmas lasted ninety-one days and did much damage on land, many of the trees were split as if struck by lightning, and men and cattle perished in some parts. Poultry and other birds and many plants and vegetables also perished. Wheat, however, was little affected, as the average price was under 40s. a quarter. In 1692 a series of very bad seasons commenced, lasting, with a break in 1694, until 1698, always known as the 'ill' or 'barren' seasons, and the cause was the usual one in England, excessive cold and wet. In 1693 wheat was over 6os. a quarter, and in Kent turnips were made into bread for the poor. ${ }^{2}$ The difference in the price of farm produce in various localities was striking, and an eloquent testimony to the wretched means of communication. At Newark, for instance, in $1692-3$ wheat was from $36 s$. to $40 s$. a quarter, while at Brentford it touched 76s.; next year in the same two places it was $32 s$. and 86s. respectively. In $1695^{-6}$ hay at Newark was I $3 s .4 d$. a ton, at Northampton it was from 35 s. to $40 s$.

In 1662 was passed the famous statute of parochial settlement, 14 Car. II, c. I2, which forged cruel fetters for the poor, and is said to have caused the iron of slavery to enter into the soul of the English labourer. ${ }^{3}$ The Act states,

1 Evelyn's Diary;

2 Tooke, History of Prices, i. 23.

Fowle, Poor Law, p. 63 . 
that the reason for passing it was the continual increase of the poor throughout the kingdom, which had become exceeding burdensome owing to the defects in the law. Poor people, moreover, wandered from one parish to another in order 'to settle where there is the best Stocke, the largest commons or wastes to build cotages, and the most woods for them to burn and destroy.' 1 It was therefore determined to stop these wanderings, and most effectually was it done. Two justices were empowered to remove any person who settled in any tenement under the yearly value of $f_{1}$ o within forty days to the place where he was last legally settled, unless he gave sufficient security for the discharge of the parish in case he became a pauper.

It is true that certain relaxations were subsequently made. The Act of 1691, 3 W. \& M., c. 2, allowed derivative settlements on payment of taxes for one year, serving an annual office, hiring for a year, and apprenticeship; while the Act of I $696,8 \& 9 \mathrm{Wm}$. III, c. 30, allowed the grant of a certificate of settlement, under which safeguard the holder could migrate to a district where his labour was required, the new parish being assured he would not become chargeable to it, and therefore not troubling to remove him till there was actual need: but the statute acted as an effectual check on migration and prevented the labourer carrying his work where it was wanted.? It became the object of parishes to have as few cottages and therefore as few. poor as possible. In 'close' parishes, i.e. where all the land belonged to one owner, as distinguished from 'open' ones where it belonged to several, all the cottages were often pulled down so that labourers coming to work in it had to travel long distances in all weathers. We shall see further relaxation in the law in 1795 , but it was not until modern times that this abominable system was destroyed. The agri-

1 Hasbach, $o p$. cit. p. 66, says, 'the abuses complained of in the preamble (of the Act) did actually exist.'

${ }^{2}$ Hasbach; op. cit. pp. 67,134 , says the statute of 1662 did not entail so much evil by hindering migration as is generally supposed. 
cultural labourer's difficulty in building a house was aggravated by the statute 3 I Eliz., c. 7, before noticed, which in order to restrain the building of cottages enacted that none, except in towns and certain other places, were to be built unless 4 acres of land were attached to them, under a penalty of $£ 10$, and 40s. a month for continuing to maintain it. This Act was not repealed until the reign of George III. However, it seems to have been frequently winked at. In Shropshire, for instance, the fine often was only nominal; in the seventeenth century orders authorizing the building of cottages on the waste were freely given by the Court of Quarter Sessions, and orders were also made by the Court for the erection of cottages elsewhere. ${ }^{1}$

At the restoration of Charles II the corn laws had practically been unaltered since $1571,{ }^{2}$ when it had been enacted that corn might be exported from certain ports in certain ships at all times when proclamation was not made to the contrary, on a payment of $\mathrm{I} 2 d$. a quarter on wheat and $8 d$. a quarter on other grain. Now both export and import were subjected to heavy duties, but these caused such high prices in corn that they were reduced in $166_{3}$; yet high duties were again imposed in 1673 , which continued until the revolution. Then, owing to good crops and low prices, which brought distress on the landed interest, a new policy was introduced: export duties were abolished and the other extreme resorted to, viz. a bounty on export of $5^{5}$. in the quarter as long as the home price did not exceed $48 s$. At the same time import duties remained high, and this system lasted till 1773. Never had the corn-growers of England been so thoroughly protected, yet, owing to causes over which the legislators had no control, namely bountiful seasons,

1 Shropshire County Records: Abstracts of the orders made by the Court of Quarter Sessions, 1638-1 782, pp. xxiv, $x x v$.

${ }^{2}$ See above, p. 70. 13 Eliz., c. 13. MCulloch, Commercial Dictionary (1852), p. 412 . 
the prices of wheat for the next seventy years was from I 5 to 20 per cent. cheaper than in the previous forty. Modern economists have described this system as one of the worst instances of a class using their legislative power to subsidize themselves at the expense of the community. As a matter of fact it was the firm conviction of the statesmen and economists of the time, that husbandry, being the main industry and prop of England, and the foundation on which the whole political power of the country was based, should receive every encouragement. At all events, in many ways the policy was successful. I It encouraged investment in land, and materially assisted the agricultural improvement for which the eighteenth century was noted, the export too employed English shipping, and thus aided industry. Arthur Young said it was the singular felicity of this country to have devised a plan which accomplished the strange paradox of at once lowering the price of corn and encouraging agriculture, for by the system in vogue till 1773 if corn was scarce it was imported, while if there was a glut at home export was assisted so that great fluctuations in price were prevented.? It seemed of the utmost importance to men of that time that England should be self-supporting and independent of possible adversaries for the necessaries of life; the wisdom of the policy was never questioned, and was accepted by, statesmen of every party. ${ }^{3}$ To blame the landowners for adopting what seemed the wisest course to every sensible person is merely an instance of partisan spite.

At the Peace of Paris in 1763 the question as to whether England or France was to be the great colonizing country of the world was finally settled, and a great development of English trade ensued. It was accompanied by a great increase of population, exports of corn were largely reduced,

1 Cunningham, English Industry and Commerce, ii. 371.

2 Political Arithmetic, pp. 27-34, 193, 276.

secky, England in the Eighteenth Century, vi. 192. 
and the balance began to incline the other way, so that the next Act of importance was that of 1773 which permitted the import of foreign wheat at a nominal duty of $6 d$. a quarter when it was over $48 s$., but prohibited export and the bounty on export when wheat was at or above $44 \mathrm{~s}$. This was the nearest approach to free trade before 1846 .

The time, however, was not yet ripe for this, and the nominal duty on imports was too small for landlords and farmers, so that in I79I the price when the same nominal duty was to come into force was raised to $54 s$., while between $50 s$. and $54 s$. a duty of $2 s .6 d$. was imposed, and under $50 s$. a duty of $24 s .3 d_{0}$; and export was allowed without bounty when wheat was under $46 s$. Export of corn, however, by this time had become a matter of little moment, England having definitely ceased to be an exporting country after 1789 .

Not only were English landowners after the Restoration anxious to protect their corn, but they also took alarm at the imports of Irish cattle which they said lowered English rents, so that in 1665 and 1680 ( 18 Car. II, c. 2, and 32 Car. II, c. 2) laws were framed absolutely prohibiting the import of Irish cattle, sheep, and swine, as well as of beef, pork, bacon, and mutton, and even butter and cheese. The statute 12 Car. II, c. 4, also virtually excluded Irish wool from England by duties amounting to prohibition. It was not until 1759 that free imports of cattle from Ireland were allowed for five years, ${ }^{1}$ a period prolonged by 5 Geo. III, c. Io, and a statute of 1772 .

In 1699 wool was allowed to be shipped from six specified ports in Ireland to eight specified ports in England, ${ }^{2}$ and by I 6 Geo. II, c. I I, wool might be sent from Ireland to any port in England under certain restrictions.

$1 \mathrm{M}^{\mathrm{e}} \mathrm{Pherson}$, Annals of Commerce, iii. $3 \mathrm{II}$.

2 Ibid. ii. 706 ; iii. $221,293$. 


\section{CHAPTER XIV}

$$
\text { I } 7 \text { CO- } 1765
$$

GENERAL CHARACTERISTICS OF THE EIGHTEENTH CENTURY.-CROPS.-CATTLE.-DAIRYING.-POULTRY.TULL AND THE NEW HUSBANDRY.-BAD TIMES.-FRUIT-GROWING

THE history of agriculture in the eighteenth century is remarkable for several features of great importance. It first saw the application of capital in large quantities to farming, the improvements of the time being largely initiated by rich landowners whom Young praises rightly as public-spirited men who deserved well of their country, though Thorold Rogers attributes a meaner motive for the improvement of their estates, namely, their desire not to be outshone by the wealthy merchants. ${ }^{1}$ They were often ably assisted by tenant farmers, many of whom were now men with considerable capital, for whom the smaller farms were amalgamated into large ones. After the agricultural revolution of the latter half of the century, the tendency to consolidate small holdings into large farms grew apace and was looked on as a decided mark of progress. This agricultural revolution was largely a result of the industrial revolution that then took place in England. Owing to mechanical inventions and the consequent growth of the factory system, the great manufacturing towns arose, whence came a great demand for food, and, to supply this demand, farms, instead of being small selfsufficing holdings just growing enough for the farmer and his family and servants, grew larger, and became manufactories of corn and meat. The century was also remarkable for another great change. England, hitherto an exporting

1 Six Centuries of Work and Wages, p. 472. 
country, became an importing one. The progress of the century was furthered by a band of men whose names are, or ought to be, household words with English farmers: Jethro Tull, Lord Townshend, Arthur Young, Bakewell, Coke of Holkham, and the Collings. Further the century witnessed a great number of enclosures, especially when it was drawing to its close. According to the Report of the Committee on Waste Lands in 1797, the number of Enclosure Acts was: under Anne, 2 Acts, enclosing I,439 acres; under Geo. I, I6 Acts, enclosing 17,960 acres ; under Geo. II, 226 Acts, enclosing $3^{1} 8,778$ acres; from I760 to I797, I,532 Acts, enclosing 2,804, 197 acres.

The period from 1700 to $176_{5}$ has been called the golden age of the agricultural classes, as the fifteenth century has been called the golden age of the labourer, but the farmer and landlord were often hard pressed; rates were low, wages were fair, and the demand for the produce of the farm constant owing to the growth of the population, yet prices for wheat, stock, and wool were often unremunerative to the farmer, and we are told in I734, 'necessity has compelled our farmers to more carefulness and frugality in laying out their money than they were accustomed to in better times.' 1

The labourer's wages varied according to locality. The assessment of wages by the magistrates in Lancashire for 1725 remains, and according to that the ordinary labourer earned Iod. a day in the summer and $9 d$. in the winter months, with extras in harvest, and this may be taken as the average pay at that date. Threshing and winnowing wheat by piece-work cost $2 s$. a quarter, oats Is. a quarter. Making a ditch 4 feet wide at the top, 18 inches wide at the bottom, and 3 feet deep, double set with quicks, cost Is. a rood ( 8 yards), rod. if without the quick. ${ }^{2}$ The magistrates remarked

1 See Baker, Record of Seasons and Prices, p. 185.

2 Eden, State of the Poor, iii. p. cvii; Thorold Rogers, Work and Wages, p. 396. 
in their proclamation on the plenty of the times and were afraid that for the northern part of the county, which was then very backward, the wages were too liberal. Wheat was, unfortunately, that year $46 s$. Id. a quarter, but a few years before and after that date it was cheap-20s., 24s., $28 \mathrm{~s}$. a quarter-and fresh meat was only $3 d$. a lb., so that their wages went a long way. ${ }^{1}$ A considerable portion of the wages was paid in kind, not only in drink but in food, though this custom became less frequent as the century went on. ${ }^{2}$

As for his food, Eden tells us ${ }^{3}$ that the diet of Bedford workhouse in 1730 was much better than that of the most industrious labourer in his own home, and this was the diet: bread and cheese or broth for breakfast, boiled beef hot or cold, sometimes with suet pudding for dinner, and bread and cheese or broth for supper. This must have been sufficiently monotonous, and we may be sure the labourer at home very seldom had boiled beef for dinner; but in the north he was much cleverer than his southern brother in cooking cereal foods such as oatmeal porridge, crowdie (also of oatmeal), frumenty or barley milk, barley broth, \&c. ${ }^{4}$

The village of the first half of the eighteenth century contained a much better graded society than the village of to-day. It had few gaps, so that there was a ladder from the lowest to the highest ranks, owing to the existence of many small holders of various degree, soon to be diminished by enclosure and consolidation. ${ }^{5}$

There was a great increase in the number of live stock owing to the spread, gradual though it was, of roots and clover, which increased the winter food ; 'of late years,' it was said in I739, 'there have been improvements made in the breed of sheep by changing of rams, and sowing of turnips,

${ }^{1}$ In Herefordshire at this time it was $\mathrm{I} \frac{1}{2} d$. per lb.

2 Hasbach, op. cit. p. 86.

' Ibid. i. 498.

3 Eden, op, cit. i. 286.

${ }^{5}$ Hasbach, op. cit. p. $7 \mathrm{I}$. 
grass seeds, \&c.' 1 Crops, too, were improving ; and enclosed lands about 1726 were said to produce over 20 bushels of wheat to the acre. ${ }^{2}$

Though the number of Enclosure Acts at the beginning of the century was nothing like the number at the end, the process was steadily going on, often by non-parliamentary enclosure, and was approved by nearly every one. Some, however, were opposed to it. John Cowper, who wrote an essay on 'Enclosing Commons' in I732, said, a common was often the chief support of forty or fifty poor families, and even though their rights were bought out they were under the necessity of leaving their old homes, for their occupation was gone; but he says nothing of the well-known increased demand for labour on the enclosed lands. The force of his arguments may be gauged from his answer to Lawrence's statement that enclosure is the greatest benefit to good husbandry, and a remedy for idleness. On the contrary, says he, who among the country people live lazier lives than the grazier and the dairyman? All the dairyman has to do is to call his cows together to be milked!

Worlidge in 1669 had lamented that turnips were so little grown by English farmers in the field, and that it was a plant 'usually nourished in gardens', ${ }^{3}$ and in a letter to Houghton in 1684 , he is the first to mention the feeding of turnips to sheep. ${ }^{4}$ However, in 1726 it was said that nothing of late years had turned to greater profit to the farmer, who now found it one of his chief treasures; and there were then three sorts: the round which was most common, the yellow, and the long. ${ }^{5}$ For winter use they were to be sown from the

${ }^{1}$ Smith, Memoirs of Wool, ii. 93 .

2 John Lawrence, New System of Agriculture, p. 45. In 1712, a normal season, 48 acres of wheat at Southwick in Hants produced 16 bushels per acre, 45 acres of barley 12 bushels per acre, 30 acres of oats 24 bushels per acre; at the same place 240 sheep realized $8 s$. each, cows $65 \mathrm{~s}$., calves $\mathscr{L}$, horses $£ 6$, hay 25 s. a ton (Hampshire Notes and Queries, iii. 120).

3 Worlidge, Systemx Agriculturae, p. 42. ${ }_{4}^{4}$ Collections, iv. 142.

- Lawrence, New System of Agriculture, p. 109. 
beginning of June to the middle of August, on fallow which had been brought to a good tilth, the seed harrowed in with a bush harrow, and if necessary rolled. When the plants had two or three leaves each they were to be hoed out, leaving them five or six inches apart, though some slovenly farmers did not trouble to do this ; but there is no mention of hoeing between the rows. The fly was already recognized as a pest, and soot and common salt were used to fight it. Folding sheep in winter on turnips was then little practised, though Lawrence strongly recommends it. According to Defoe, ${ }^{1}$ Suffolk was remarkable for being the first county where the feeding and fattening of sheep and other cattle with turnips was first practised in England, to the great improvement of the land, 'whence', he says, 'the practice is spread over most of the east and south, to the great enriching of farmers and increase of fat cattle.' There were great disputes as to collecting the tithe, always a sore subject, on turnips; and the custom seems to have been that if they were eaten off by store sheep they went tithe free, if sheep were fattened on them the tithe was paid. ${ }^{2}$

Clover, the other great novelty of the seventeenth century, was now generally sown with barley, oats, or rye grass, about $r_{5}$ lb. per acre. This amount, sown on 2 acres of barley, would next year produce 2 loads worth about $£ 5$. The next crop stood for seed, which was cut in August, the hay being worth $£ 9$, and the seed out of it, $300 \mathrm{lb}$., was sold much of it for $\mathrm{I} 6 \mathrm{~d}$. a lb., the sum realized in that year from the 2 acres being $£_{3}$, without counting the aftermath. At this time most of the seed was still imported from Flanders. ${ }^{3}$ Much of the common and waste land of England, not previously worth $6 d$. an acre, had been by 1732 vastly improved through sowing artificial grasses on it, so that various people had gained considerable estates. ${ }^{4}$

1 Tour (ed. 1724), i. 87. ${ }^{2}$ Ellis, Chiltern and Vale Furming, p. 353.

3 Bradley, General Treatise, i. 175.

4 Ellis, Chiltern and Vale Farming, p. 260. 
Carrots were also now grown as a field crop in places, especially near London, two sorts being known, the yellow and red, used chiefly by farmers for feeding their hogs. ${ }^{1}$ Of wheat the names were many, but there were apparently only seven distinct sorts, the Double-eared, Eggshell, Red or Kentish, Great-bearded, Pollard, Grey, and Flaxen or Lammas. ${ }^{2} \quad$ The growth of saffron had declined, though the English variety was the best in the world, according to Lawrence, and except in Cambridgeshire and about Saffron Walden it was little known.

Though it was still some time before the days of Bakewell, increased attention was given to cattle-breeding; it was urged that a well-shaped bull be put to cows, one that had 'a broad and curled forehead, long horns, fleshy neck, and a belly long and large.' ${ }^{3}$ Such in 1726 was the ideal type of the longhorns of the Midland and the north, but it was noticed that of late years and especially in the north the Dutch breed was much sought after, which had short horns and long necks, the breed with which the Collings were to work such wonders. The then great price of $£ 20$ had been given for a cow of this breed. Bradley, Professor of Botany at Cambridge, and a well-known writer on agriculture, divided the cattle of England into three sorts according to their colour: the black, white, and red. ${ }^{4}$ The black, commonly the smallest, was the strongest for labour, chiefly found in mountainous countries; also bred chiefly in Cheshire, Yorkshire, Lancashire, and Derbyshire, sixty years before this, and in those days Cheshire cheese came from these cattle, apparently very much like the modern Welsh breed. ${ }^{5}$ The white were much larger, and

$1 \mathrm{~J}$. Lawrence, New System of Agriculture, p. II 2.

2 Ibid. p. 92. About 1757 Lucerne, hitherto little grown in England, took its place in the rotation of crops.

${ }^{4} A$ General Treatise on Husbandry (1726), i. 72 ; cf. c.

5 The black cattle seem to have been spread very generally over England, according to previous writers and to Defoe, who often mentions them. He saw a 'prodigious quantity' in the meadows by the Waveney in Norfolk. - Tour, i. 97. 
very common in Lincolnshire at the end of the seventeenth century. They gave more milk than the black sort but went dry sooner. They were also found in Suffolk and Surrey.

The red cattle were the largest in England, their milk rich and nourishing, so much so that it was given specially to consumptives. They were first bred in Somerset, where in Bradley's time particular attention was paid to their breeding, and were evidently the ancestors of the modern Devons. About London these cows were often fed on turnips, given them tops and all, which made their milk bitter. They were also found in Lincolnshire and some other counties, where 'they were fed on the marshes', and Defoe saw, in the Weald of Kent, "large Kentish bullocks, generally all red with their horns crooked inward.' Bradley gives the following balance sheet for a dairy of nine cows ${ }^{1}$ :

DR. $\mathcal{L}$ s. $d$.

6 months' grass keep at $15.6 \pi$. per week per head 17 iI 0 6 months' winter keep (straw, hay, turnips, and grains) at $2 s$. per week per head .

. $\begin{array}{r}2380 \\ 240190 \\ \hline\end{array}$

$\mathrm{C}_{\text {R }}$

I3,140 gallons of milk . . . . . . 136176

$$
\text { Balance (profit) } \lcm{40190}
$$

A correspondent, however, pointed out to Bradley that this yield and profit was far above the average, which was about $£ 5$ a cow, on whom Bradley retorted that it could be made, though it was exceptional.

In the eighteenth century the great trade of driving Scottish cattle to London began, Walter Scott's grandfather being the pioneer. The route followed diverged from the Great North Road in Yorkshire in order to avoid turnpikes, and the cattle, grazing leisurely on the strips of grass by the road-side, generally arrived at Smithfield in good condition.?

' Bradley, General Treatise, i. 76. ${ }^{2}$ Slater, English Peasantry, p. 52. 
Defoe tells us that most of the Scottish cattle which came yearly into England were brought to the village of S. Faiths, north of Norwich, 'where the Norfolk graziers go and buy them. These Scots runts, coming out of the cold and barren highlands, feed so eagerly on the rich pasture in these marshes that they grow very fat. There are above 40,000 of these Scots cattle fed in this county every year. The gentlemen of Galloway go to England with their droves of cattle and take the money themselves.' ${ }^{1}$ It was no uncommon thing for a Galloway nobleman to send 4,000 black cattle and 4,000 sheep to England in a year, and altogether from 50,000 to 60,000 cattle were said to come to England from Galloway yearly. Gentlemen on the Border before the Union got a very pretty living by tolls from these cattle; and the Earl of Carlisle made a good income in this way.

Cattle were sometimes of a great size. In 1697 , in the park of Sir John Fagg near Steyning, Defoe saw four bullocks of Sir John's own breeding for which was refused in Defoe's hearing $£_{26} 6$ apiece. They were driven to Smithfield and realized $£_{25}$ each, having probably sunk on the way, but dressed they weighed 80 stone a quarter $!^{2}$ These weights must have been very exceptional, but go to prove that cattle then could be grown to much greater size than is generally credited. A good price for a bullock in the first half of the eighteenth century was from $£ 7$ to $£$ io.

The best poultry at the same date $(1726)$ were said to be 'the white-feathered sort', especially those that had short and white legs, which were esteemed for the whiteness of their flesh; but those that had long yellow legs and yellow beaks were considered good for nothing. ${ }^{3}$ Care was to be used in the choice of a cock, for those of the game kind were to be avoided as unprofitable. Bradley gives a balance sheet for

1 Tour (ed. 1724), i. (1) 97, and iii. (2) 73.

2 Ibid. i. 63.

3 J. Lawrence, New System of Agriculture, p. 151. 
I 2 hens and 2 cocks who had a free run in a farmyard and an orchard : 1

DR. $\quad £$ s. $d$.

39 bushels of barley $\quad \begin{array}{ccc}3 & 5 & 0\end{array}$

Balance, profit $\because \quad . \quad 160$

$$
£ \overline{4 \quad 1 \quad 0}
$$

CR. Eggs (number unfortunately not given) . I 50 20 early chickens at $1 s$. . I 0 o 72 late chickens at $6 d$. I 160 $£ 4$ I 0

He also recommends that in stocking a farm of $£ 200$ a year the following poultry should be purchased:

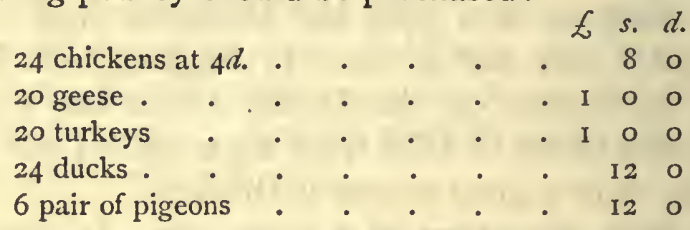

The best way to fatten chickens, according to Bradley, was to put them in coops and feed them with barley meal, being careful to put a small quantity of brickdust in their water to give them an appetite.?

On this farm were 20 acres of cow pasture besides common, and this with some turnips kept 9 cows, which gave about three gallons of milk a day at least, the milk being worth $I d$. a quart. His pigs were of the 'Black Bantham' breed, which were better than the large sort common in England, for the flesh was much more delicate.

Suffolk was famous for supplying London with turkeys. ${ }^{3}$ Three hundred droves of turkeys, each numbering from 300 to 1000 , had in one season passed over Stratford Bridge on the road from Ipswich to London. Geese also travelled on foot to London in prodigious numbers from Norfolk, Suffolk, and the Fen country, often $I, 000$ to 2,000 in a drove, starting in August when harvest was nearly over, so that the geese

1 Bradley, General Treatise, i. Ino.

2 Country Gentleman and Farmer's Director (1726), p. 7.

3 Defoe, Tour, i. 87. 
might feed on the stubble by the way; 'and thus they hold on to the end of October, when the roads begin to be too stiff and deep for their broad feet and short legs to march on.' There was, however, a more rapid method of getting poultry to the great market, by means of carts of four stages or stories, one above another, to carry the birds in, drawn by two horses, which by means of relays travelled night and day, and covered as much as 100 miles in two days and one night, the driver sitting on the topmost stage.

Hop growing in 1729 , according to Richard Bradley, paid well; he says, 'ground never esteemed before worth a shilling an acre per annum, is rendered worth forty, fifty, or sometimes more pounds a year by planting hops judiciously. An acre of hops shall bring to the owner clear profit about $£ 30$ yearly ; but I have known hop grounds that have cleared above $€ 50$ yearly per acre.' At this date 12,000 acres in England were planted with hops.

The great market for hops was Stourbridge Fair, once the greatest mart in England and still preserving much of its former importance: 'there is scarce any price fixed for hops in England till they know how they sell in Stourbridge Fair.' ${ }^{1}$ Thither they came from Chelmsford, Canterbury, Maidstone, and Farnham, where the bulk of the hops in England were then grown, though some were to be found at Wilton near Salisbury, in Herefordshire, and Worcestershire. Round Canterbury Defoe says there were 6,000 acres of hops, all planted within living memory"; but the Maidstone district was called ' the mother of hop grounds', and with the country round Feversham was famous for apples and cherries.

The finest wool still, it seems, came from near Leominster, where the sheep in Markham's time were described as smallboned and black-faced, with a light fleece, and apparently they still had the same appearance at the beginning of the

1 Defoe, Tour (3rd ed.), i. 81 .

2 Defoe, Tour (ed. 1724), ii. I, 134. 
eighteenth century ${ }^{1}$; and large-boned sheep with coarser wool were to be found in the counties of Warwick, Leicester, Buckingham, Northampton, and Nottingham; in the north of England too were big-boned sheep with inferior wool, the largest with coarse wool being found in the marshes of Lincolnshire.

About this time wool had fallen much in price: 'Has nobody told you,' writes a west country farmer to his absentee landlord in 1737 , 'that wool has fallen to near half its price, and that we cannot find purchasers for a great part of it at any price whatsoever. When most of our estates (farms) were taken wool was generally $7 d$., $8 d$., or more by the pound ; the same is now $4 d$. and still falling.' "

But the latter price was exceptionally low; Smith $^{3}$ gives the following average prices per tod of $28 \mathrm{lb}$.:

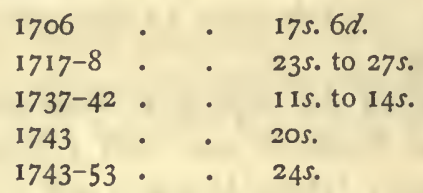

After 1753 it fell again, largely owing to the great plague among cattle, which brought about a 'prodigious increase ${ }^{4}$ of sheep'; and about 1770 Young ${ }^{5}$ favoured corn rather than wool, for there was always a market for the former, but the foreign demand for cloth was diminishing, especially in the case of France, besides prohibition of export kept down the price. ${ }^{6} \quad$ Yet although wool was being deserted for corn it had in Young's time 'been so long supposed the staple and

1 Bradley, General Treatise, i. 160; see also Smith, Memoirs of Wool, ii. 169, where the sheep of Leominster, of Cotteswold, and of the Isle of Wight are said to be the best in 1719. The great market for sheep was Weyhill Fair, and Stourbridge Fair was a great wool market.

${ }_{2}$ The West Country Farmer, a Representation of the Decay of Tradc, 1737.

Memoirs of Wool, ii. 243.

- Farmer's Ietters (3rd ed.), p. 27.

4 Ibid. ii. 399.

- Cunningham, Industry and Commerce, ii. 384 . 
foundation of all our wealth, that it is somewhat dangerous to hazard an opinion not consonant to its encouragement'.

At the end of the century, however, there was a rapid increase in the price, partly due to increased demand by spinners and weavers who, owing to machinery, were working more economically; and partly to the enclosure of commons, and the ploughing up of land for corn. ${ }^{1}$

Cheshire had long been famous for cheese. Barnaby Googe, in the last quarter of the sixteenth century, says, 'in England the best cheese is the Cheshyre and the Shropshyre, then the Banbury cheese, next the Suffolk and the Essex, and the very worst the Kentish cheese.' Camden, who died in I623, tells us that 'the grasse and fodder (in Cheshire) is of that goodness and vertue that cheeses be made here in great number, and of a most pleasing and delicate taste such as all England again affordeth not the like, no though the best dairywomen otherwise and skillfullest in cheese making be had from hence;' and a little later it was said no other county in the realm could compare with Cheshire, not even that wonderful agricultural country Holland from which England learnt so much. ${ }^{2}$ In Lawrence's time Cheddar cheese was also famous, and there it had long been a custom for several neighbours to join their milk together to make cheeses, which were of a large size, weighing from $30 \mathrm{lb}$. to Ioo lb. Good cheese came also from Gloucestershire and Warwickshire. The Cheshire men sent great quantities by sea to London, a long and tedious voyage, or else by land to Burton-on-Trent, and down that river to Hull and then by sea to London. The Gloucestershire men took it to Lechlade and sent it down the Thames; from Warwickshire it went by land all the way, or to Oxford and thence down the Thames to London. Stilton, too, had lately become famous, and was considered the best of all, selling for the then great price of $\mathrm{I} s$. a lb. on the farm,

1 Cunningham, Industry and Commerce, ii. 458.

2 Ormerod, Cheshire, i. 129. These words were written about 1656. 
and $2 s .6 d$. at the Bell Inn, Stilton, where it seems to have first been sold in large quantities, though Leicestershire perhaps claims the honour of first making it. ${ }^{1}$

The eastern side of Suffolk was, in Defoe's time, famous for the best butter and perhaps the worst cheese in England, the butter being 'barrelled and sometimes pickled up in small casks'?2

Rabbits were occasionally kept in large numbers for profit; at Auborne Chase in Wilts. there was a warren of 700 acres surrounded by a wall-a most effective way of preventing escape, but somewhat expensive. In winter time they were fed on hay, and hazel branches from which they ate the bark. They were never allowed to get below 8,000 head, and from these, after deducting losses by poachers, weazles, polecats, foxes, \&c., 24,000 were sold annually. These rabbits, owing to the quality of the grass, were famous for the sweetness of their flesh. The proprietor, Mr. Gilbert, began to kill them at Bartholomewtide, Aug. 24, and from then to Michaelmas obtained $9 s$. a dozen for them delivered free in London; but those from Michaelmas to Christmas realized Ios. $6 d$. a dozen.

The difference in price at the two periods is accounted for by the fact that their skins were much better in the latter, and the rabbits kept longer when killed; they must also have been larger. A skin before Michaelmas was only worth $\mathrm{I} d$., but soon after nearly $6 d$.; and in Hertfordshire was a warren where rabbit skins with silvery hair fetched Is. each. ${ }^{3}$

We have now reached the period when the result of Jethro Tull's labours was given to the world, his Horse-hoeing Husbandry appearing in I733. It is no exaggeration to say that agriculture owes more to Tull than to any other man;

${ }^{1}$ See Victoria County History: Rutland, Agriculture. Stilton was eaten in the same condition as many prefer it now, "with the mites round it so thick that they bring a spoon for you to eat them.'

${ }^{2}$ Defoe, Tour, i. (I) 78. Cheshire cheese was $2 d$. to $21 \%$. per $1 \mathrm{~b}$., Cheddar $6 d$. to $8 d$. in 1724 , an extraordinary difference.

3 Bradley, i. 172. 
the principles formulated in his famous book revolutionized British agriculture, though we shall see that it took a long time to do it. He has indeed been described as 'the greatest individual improver agriculture ever knew'. He first realized that deep and perfect pulverization is the great secret of vegetable nutrition, and was thus led on to perfect the system of drilling seed wide enough apart to admit of tillage in the intervals, and abandoning the wide ridges in vogue, laid the land into narrow ridges 5 feet or 6 feet wide. He was born at Basildon in Berkshire, heir to a good estate, and was called to the bar in 1699, but on his marriage in the same year settled on the paternal farm of Howberry in Oxfordshire. In his preface to his book he throws a flash of light on country life at a time when the roads were nearly as bad as in the Middle Ages, so that they effectually isolated different parts of England, when he speaks of 'a long confinement within the limits of a lonely farm, in a country where I am a stranger, having debarred me from all conversation'. ${ }^{1}$

He took to agriculture more by necessity than by choice, for he knew too much ' the inconveniency and slavery attending the exorbitant power of husbandry servants', and he further gives this extraordinary character of the farm labourer of his day: "Tis the most formidable objection against our agriculture that the defection of labourers is such that few gentlemen can keep their land in their own hands, but let them for a little to tenants who can bear to be insulted, assaulted, kicked, cuffed, and Bridewelled, with more patience than gentlemen are endowed with.' ${ }^{2}$ Tull wrote just before it became the fashion for gentlemen to go into farming, and laments that the lands of the country were all, or mostly, in the hands of rack-renters, whose supposed interest it was that they should never be improved for fear of fines and increased rents. Gentlemen then knew so little of farming that they were

1 Preface to Horse-hoeing Husbandry (ed. 1733).

2 Horse-hoeing Husbandry, p. vi. 
unable to manage their estates. No doubt his scathing remarks helped to initiate the well-known change in this respect, and soon, over all England, gentlemen of education and position were engaged in removing this reproach from their class. The same complaint as to their ignorance of matters connected, with their land crops up again during the great French war, but they then had a good excuse, as they were busy fighting the French.

Tull invented his drill about I 701 at Howberry. The first occasion for making it, he says, was that it 'was very difficult to find a man that could sow clover tolerably; they had a habit to throw it once with the hand to two large strides and go twice in each cast; thus, with 9 or $10 \mathrm{lb}$. of seed to an acre, two-thirds of the ground was unplanted. To remedy this I made a hopper, to be drawn by a boy, that planted an acre sufficiently with $6 \mathrm{lb}$. of seed; but when I added to this hopper an exceeding light plough that made 6 channels eight inches asunder, into which $2 \mathrm{lb}$. to an acre being drilled the ground was as well planted. This drill was easily drawn by a man, and sometimes by a boy.'

His invention was largely prompted by his desire to do without the insolent farm servant whom he has described above, and the year after it was invented he certainly had his wish, for they struck in a body and were dismissed: ' it were more easy to teach the beasts of the field than to drive the ploughman out of his way.'

His ideas were largely derived from the mechanism of the organ which, being fond of music, he had mastered in his youth-a rotary mechanism, which is the foundation of all agricultural sowing implements. His first invention may be described as a drill plough to sow wheat and turnip seed in drills three rows at a time, a harrow to cover the seed being attached. Afterwards he invented a turnip drill, so arranged as regards dropping the seed and its subsequent covering with soil that half the seed should come up earlier than the rest, to 
enable a portion at least to escape the dreaded fly. He was a great believer in doing everything himself, and worked so hard at his drill that he had to go abroad for his health. He was somewhat carried away by his invention, and asserts that the expense of a drilled crop of wheat was one-ninth of that sown in the old way, giving the following figures to prove his assertion :

\section{The Old Way}

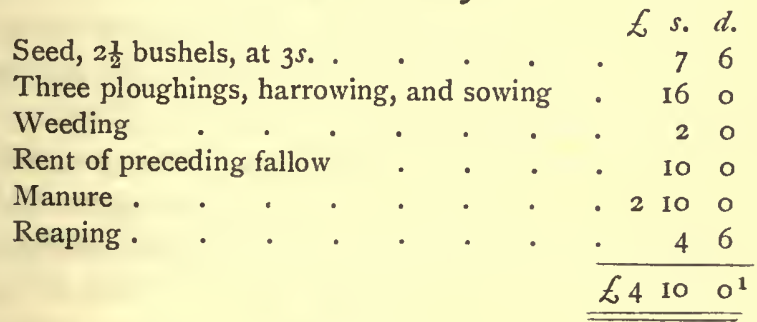

The Nerw Way

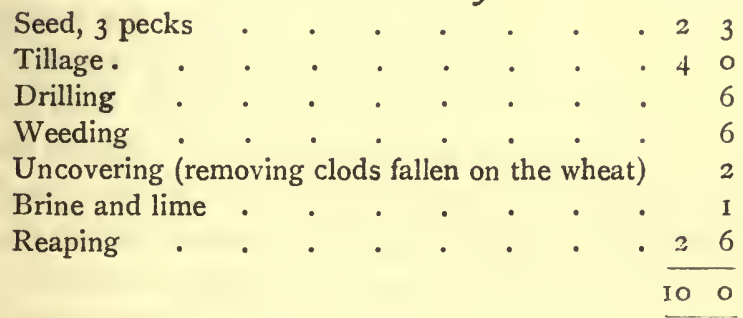

It should be noted that he has omitted to charge rent for the year in which the crop was grown in both cases.

He considered fallowing and manure unnecessary, and grew without manure 13 successive wheat crops on the same piece of ground, getting better crops than his neighbours who pursued the ordinary course of farming. His three great principles, indeed, were drilling, reduction of seed, and absence of weeds, and he saw that dung was a great carrier of the latter but lacked a due appreciation of its chemical action. Of

1 The West Country Farmer, above quoted, says wheat growing (in 1737) paid little. Before a bushel can be sold it costs $£ 4$ an acre, and the crop probably fetches half the money. 
course, like all improvers, he was met with unlimited opposition, and on the publication of his book he was assailed with abuse, which, being a sensitive man, caused him extreme annoyance. His health was bad, his troubles with his labourers unending, his son a spendthrift, and he died at his now famous home, Prosperous Farm, near Hungerford, in I 74I, having said not long before his death, 'Some, allowed as good judges, have upon a full view and examination of my practice declared their opinion that it would one day become the general husbandry of England.' 1 Scotland was the first to perceive the merits of the system, and it gradually worked southwards into England, but for many years had to fight against ignorance and prejudice, even so intelligent a man as Arthur Young being opposed to it.

Farm leases had by this time assumed their modern form, and cultivation clauses were numerous. In one of 1732 , at Hawsted, the tenant was to keep the hedges in repair, being allowed bushes and stakes for so doing. He was also to bestow on some part of the lands one load of good rotten muck over and above what was made on the farm for every load of hay, straw, or stover (fodder) which he should carry off.? In another of I740, he was to leave in the last year of the tenancy one-third of the arable land summer tilled, ploughed, and fallowed, for which he was to be paid according to the custom of the country. In 1753 , in the lease of Pinford End Farm, there was a penalty of $£$ Io an acre for breaking up pasture; a great increase in the amount of the penalty. All compost, dung, soil, and ashes arising on the farm were to be bestowed upon it.

Only two crops successively were to be taken on any of the arable land, but land sown with clover and rye-grass, if fed off, or with turnips which were fed on some part of the farm, were not to count as crops.

The ashes mentioned were those from wood, which were now carefully looked after, as it had become the custom to

1 R.A.S.E. Journ. (3rd Ser.), ii. 20. 2 Cullum, Hawsted, p. 216. 
sell them to the soap-boilers, who came round to every farm collecting them. This is the earliest mention in a Hawsted lease of rye-grass, clover, and turnips, though clover and turnips had been first cultivated there about I700, and soon spread.

The winter of $1708-9$ was very severe, a great frost lasting from October until the spring; wheat was $8 I s .9 d$. a quarter, and high prices lasted until $1715 .^{1}$

From $x_{7} I_{5}$ to $x_{76}$ was an era of good seasons and low prices generally; in that half-century Tooke says there were only five bad seasons. In 1732 prices of corn were very low, wheat being about $24 \mathrm{~s}$. a quarter, so that we are not surprised to find that its cultivation often did not pay at all." At Little Gadsden in Hertfordshire, in that year a fair season, and on enclosed land, the following is the balance sheet for an acre:

Rent

DR.

$$
\text { Ł. } d \text {. }
$$

Dressing (manuring)

$2 \frac{1}{2}$ bushels of seed .

Ploughing first time twice more

Harrowing

Reaping and carrying .

Threshing

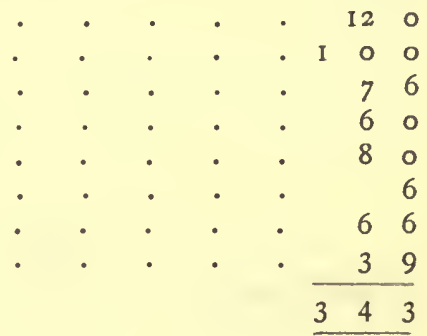

CR.

15 bushels of wheat (a poor crop, as $20 £$ s. $d$.

bushels was now about the average). $\begin{array}{lll}2 & 2 & 0\end{array}$

Straw : . . . . . II 6

Loss

$\frac{2136}{109}$

On barley, worth about $£ \mathrm{I}$ a quarter, the loss was 3 s. $6 d$. an 1 Tooke, History of Prices, i. 35.

2 Wheat averaged:

$1718-22$ about $27 s$.

$1724,36 s$.

$1725 " 46 s$.

$1726,35 s$.

$1728,52 s$.
1730 about 30 s.

$1732,24 s$.

$1736 " 30 s$.

$1740, \quad 42 s$.

$1744 " 235$.
1750 about 30 s.

$1755 " 35 s$.

$1760 " 38 s$.

$1765 " 42 s$. 
acre; on oats, worth I 3 s. a quarter, however, the profit was $2 I s$.; on beans, $26 s$. $6 d$., these being that year exceptionally good and worth 20s. a quarter. ${ }^{1}$ Ellis objected to the new mode of drilling wheat because, he said, the rows are more exposed to the violence of the winds, rains, \&c., by growing apart, than if close together, when the stalks support each other. ${ }^{2}$ This estimate may be compared to that of Tull for the 'old way' of sowing wheat, ${ }^{3}$ and to the following estimate of fifty years later in Surrey, when wheat was a much better price :-

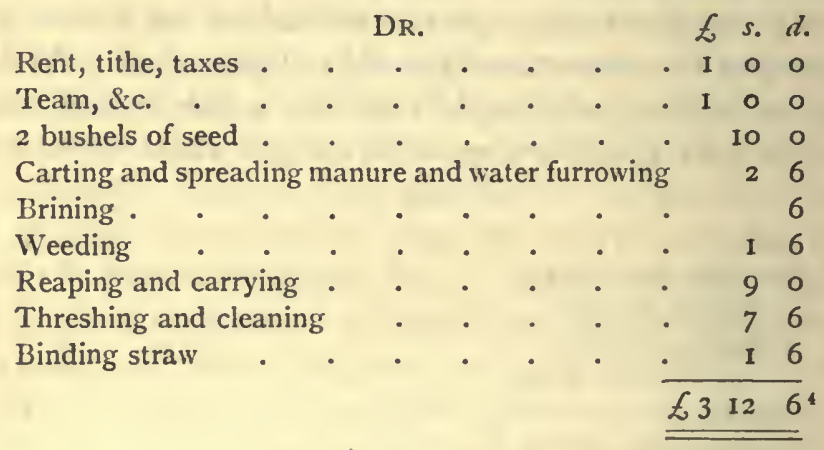

CR.

20 bushels at 5 s. . . . . . . . 500

$1 \frac{1}{2}$ loads of straw

$\begin{array}{r}126 \\ 6626 \\ \hline\end{array}$

The profit was thus $£_{2}$ Ios. od. an acre, and for barley it was $£_{3} 3^{s}$. $6 d$., for oats $£^{\mathrm{I}} \mathrm{I} 9 s$. rod., for beans $£ \mathrm{I}$ I $3 s . d^{5}$

This crop of wheat was not very good, as the average in that district was from 20 to 25 bushels per acre, and Young before this saw crops of 30 bushels per acre growing. 'The

1 Ellis, Chiltern and Vale Farming, p. 209. Nothing is charged for tithe and taxes.

2 Ibid. p. 352 .

See above, p. 177 , also p. 199 for Young's estimate in 1770.

- Nothing is charged for the manure which was carted and spread.

' John Trusler, Practical Husbandry, p. 28. 
over frequent use of fallows, which had so long marked agriculture, was in the early half of the eighteenth century beginning to be strongly disapproved of. Bradley advocated the continuous cultivation of the ground with different kinds of crops, 'for I find', he said, 'by experience that if such crops are sown as are full of fibrous roots, such roots greatly help to open the parts of grounds inclining to too much stiffness.' 1

${ }^{1}$ Country Gentleman and Farmer's Director (1726), p. xiii. 


\section{CHAPTER XV}

$$
1700-1765
$$

TOWNSHEND. - SHEEP ROT. - CATTLE PLAGUE. FRUIT-GROWING

IN 1730 Charles, second Viscount Townshend, retired from politics, on his quarrel with his brother-in-law Walpole, who remarked that 'as long as the firm was Townshend and Walpole the utmost harmony prevailed, but it no sooner became Walpole and Townshend than things went wrong'. He devoted himself to the management of his Norfolk estates and set an example to English landlords in wisely and diligently experimenting in farm practice which was soon followed on all sides, the names of Lords Ducie, Peterborough, and Bolingbroke being the best known of his fellow-labourers. A generation afterwards Young wrote, ' half the County of Norfolk within the memory of man yielded nothing but sheep feed, whereas those very tracts of land are now covered with as fine barley and rye as any in the world and great quantities of wheat besides.' 1 There can be no doubt from this statement, made by an eyewitness of exceptional capacity, that he commenced the work so nobly carried on by Coke. The same authority tells us that when Townshend began his improvements near Norwich much of the land was an extensive heath without either tree or shrub, only a sheepwalk to another farm; so many carriages crossed it that they would sometimes be a mile abreast of each other in pursuit of the best track. By 1760 there was an excellent turnpike road, enclosed on each side with a good quickset hedge, and all the land let out in enclosures and cultivated on the Norfolk system in superior style; the 
whole being let at $\mathrm{I}_{5} \mathrm{~s}$, an acre, or ten times its orignal value. Townshend's two special hobbies were the field cultivation of turnips, and improvement in the rotation of crops. Pope says his conversation was largely of turnips, and he was so zealous in advocating them that he was nicknamed 'Turnip Townsend '. He initiated the Norfolk or four-course system of cropping, in which roots, grasses, and cereals were wisely blended, viz. turnips, barley, clover and rye grass, wheat. He also reintroduced marling to the light lands of Norfolk, and followed Tull's system of drilling and horsehoeing turnips, with the result that the poor land of which his estate was largely composed was converted into good corn and cattle-growing farms. Like all the progressive agriculturists of the day, he was an advocate of enclosures, and he had no small share in the growth of the movement by which, in the reigns of Anne and the first two Georges, 244 enclosure Acts were passed and $33^{8}, \mathbf{1} 77$ acres enclosed. The progress of enclosure was alleged as a proof that England was never more prosperous than under Walpole; the number of private gentlemen in Britain of ample estates was said to exceed that of any country in the world proportionately, and was far greater than in the reign of Charles II. The value of land at twenty-six or twenty-seven years' purchase was a conclusive proof of the wealth of England. ${ }^{2}$

Though, however, the first half of the century was generally prosperous there were bad times for farmer and landlord. We have seen that wheat-growing paid little, although from 1689 to 1773 the farmer was protected against imports and aided by a bounty on exports. In 1738 Lord Lyttelton wrote : 'In most parts of England, gentlemen's rents are so ill paid and the weight of taxes lies so heavy upon them that those who have nothing from the Court can scarce support their families.' ${ }^{3}$

1 R. A. S. E. Journal (3rd Series), iii. I.

2 See the Hyp Doctor, No. 49.

3 Tooke, History of Prices, i. 42. 
Sheep in the damp climate of England have always been subject to rot, and in I 735 there was, according to Ellis, the most general rot in the memory of man owing to a very wet season; and, as in the disastrous year of 1879 , which must be fresh in many farmers' memories, other animals, deer, hares, and rabbits, were affected also; and the dead bodies of rotten sheep were so numerous in road and field that the stench was offensive to every one. Another bad outbreak occurred in 1747. It is well known that farmers are always grumblers, probably with an eye to the rent; but even in these much praised times they apparently made small profits. The west country farmer quoted before, who had been fifty years on the same estate, and writes with the stamp of sincerity, admits in 1737 that 'with all the skill and diligence in the world he can hardly keep the cart upon the wheels. Wool had gone down, wheat didn't pay and graziers were doing badly; tho' formerly our cattle and wool was always a sure card'. He says that the profits of grazing were reckoned at one-third of the improvement that ensued from the grazing, but the grazier was not now getting this. He attributed much of the distress, however, to the extravagance of the times. Landlords, including his own, preferred London to the country, and spent their money there. How different was the behaviour of his landlord's grandfather. 'Many a time would his worship send for me to go a-hunting or shooting with him; often would he take me with him on his visits and would introduce me as his friend. The country gentlewoman and the parson's wife, that used to stitch for themselves, are now so hurried with dressings and visits and other attractions that they hire an Abigail to do it.'

He thought, too, the labourers were getting too high wages; ' they are so puffed up by our provender as to offer us their heels and threaten on any occasion to leave us to do our work ourselves.' One would like to hear the labourers' opinion on this point, but they were dumb. In spite of higher wages the 
young men and young women flocked to the cities, and those who remain were lazy and extravagant, even the country wenches contending about 'double caps, huge petticoats, clock stockings, and other trumpery'. 1

The bounty now paid on the export of wheat was naturally resented by the common people, as it raised the price of their bread. In 1737 a load belonging to Farmer Waters of Burford, travelling along the road to Redbridge for exportation, was stopped near White parish by a crowd of people who knocked down the leading horse, broke the wagon in pieces, cut the sacks, and strewed about the corn, with threats that they would do the like to all who sold wheat to export. ${ }^{2}$ While England was paying farmers to export wheat she was also importing, though in plentiful years importers had a very bad time. In 1730 there were lying at Liverpool 33,000 windles (a windle-220 lb.) of imported corn, unsaleable owing to the great crop in England. ${ }^{3}$ The year 1740 was distinguished by one of the severest winters on record. From January $I$ to February 5 the thermometer seldom reached $32^{\circ}$, and the cold was so intense that hens and ducks, even cattle in their stalls died of it, trees were split asunder, crows and other birds fell to the ground frozen in their flight. This extraordinary winter was followed by a cold and late spring; no verdure had appeared by May; in July it was still cold, and thousands of acres of turnips rotted in the ground. Among minor misfortunes may be noticed the swarms of grasshoppers who devastated the pastures near Bristol at the end of August I 742, ${ }^{4}$ and the swarms of locusts who came to England in I 748 and consumed the vegetables. ${ }^{5}$

The cattle plague of $1745^{6}$ was so severe that owing to the

${ }^{3}$ Cf. this and Tull's character of servants with Defoe's accusation of their laziness.

2 Salisbury newspaper, quoted by Baker, Seasons and Prices, p. 187.

3 See Autobiography of $W m$. Stout, ed. by J. Harland.

4 Gentleman's Magazine, 1742.

- A Defence of the Farmers of Great Britain (1814), p. 30. 
scarcity of stock great quantities of grass land were ploughed up, which helped to account for the fact that in 1750 the export of corn from England reached its maximum; though the main cause of this was the long series of excellent seasons that set in after $17400^{1}$ The cattle plague also raged in 1754 in spite of an Order in Council that all infected cattle should be shot and buried $4 \mathrm{ft}$. deep, and pitch, tar, rosin, and gun. powder burnt where infected cattle had died, and cow-houses washed with vinegar and water. Such were the sanitary precautions of the time. ${ }^{2}$ In $175^{6}$ came another bad year, corn was so scarce that there were many riots; the king expressed to Parliament his concern at the suffering of the poor, and the export of corn was temporarily prohibited. The fluctuations in price are remarkable: in 1756 , before the deficiency of the harvest was realized, wheat was $22 \mathrm{~s}$. and it went up at the following rate: Jan., I 757, 49s.; Feb., 5 I s. ; March, 54s.; April, 64s.; June, $72 s$.

About the middle of the century, if we may judge from the Compleat Cyderman, written in 1754 by experienced hands living in Devon, Cornwall, Herefordshire, and elsewhere, fruitgrowing received an amount of attention which diminished greatly in after years. The authors fully realized that an orchard under tillage causes apple trees to grow as fast again as under grass, and this was well understood and practised in Kent, where crops of corn were grown between the trees.

A Devonshire 'cyderist' urged that orchards should be well sheltered from the east winds, which 'bring over the narrow sea swarms of imperceptible eggs, or insects in the air, from the vast tracts of Tartarian and other lands, from which proceeded infinite numbers of lice, flies, bugs, caterpillars, cobwebs, \&c.'

1 Tooke, History of Prices, i. 42.

2 See a curious pamphlet called $A n$ Exhortation to all People to Consider the Afflicting Hand of God (1754), p. 6. The plague lasted from 1745 to 1756 . 
The best protection was a screen of trees, and the best tree for the purpose, a perry pear tree. In the hard frosts of 1709 , I 7 I6, and 1740 great numbers of fruit and other trees had been destroyed. In Devon what was called the 'Southams method' was used for top-dressing the roots of old apple trees, which was done in November with soil from the roads and ditches, or lime or chalk, laid on furze sometimes, 6 inches thick, for 4 or $5 \mathrm{ft}$. all round the trees. Great attention was paid there to keeping the heads of fruit trees in good order, so that branches did not interfere with each other, ${ }^{1}$ and the heads were made to spread as much as possible. Many of the trees were grown with the first branches commencing $4 \mathrm{ft}$. 6 in. from the ground. It was claimed that Devon excelled all other parts of England in the management of fruit trees, a reputation that was not maintained, according to the works of half a century later. The best cider apple in the county then was the White-sour, white in colour, of a middling size, and early ripe; other good ones were the 'Deux-Anns, Jersey, French Longtail, Royal Wilding, Culvering, Russet, Holland Pippin, and Cowley Crab.' In Herefordshire it was the custom to open the earth about the roots of the apple trees and lay them bare and exposed for the 'twelve days of the Christmas holidays', that the wind might loosen them. Then they were covered with a compost of dung, mould, and a little lime. 'The best way' to plant was to take off the turf and lay it by itself, then the next earth or virgin mould, to be laid also by itself. Next put horse litter over the bottom of the hole with some of the virgin mould on that, on which place the tree, scattering some more virgin mould over the roots, then spread some old horse-dung over this and upon that the turf, leaving it in a basin shape. The ground between the trees in Devonshire in young orchards was first planted with cabbage plants, next year with potatoes, next with beans, and so on until the heads of the trees became large enough,

1 The Compleat Cyderman, p. 46. 
when the land was allowed to return to pasture, a proceeding which was quite contrary to their previously quoted assertion that tillage was best for fruit trees. The cider-makers were quite convinced, as many are to-day, that rotten apples were invaluable for cider, and the lady who was famous for the best cider in the county never allowed one to be thrown away. A generation later than this Marshall ${ }^{1}$ noted that in Herefordshire the management of orchards and their produce was far from being well understood, though 'it has ever borne the name of the first cider county'. All the old fruits were lost or declining in quality, the famous Red Streak Apple was given up and the Squash Pear no longer made to flourish.

As for prices, in 1707 apples were selling at Liverpool for $2 s$. $6 d$. a bushel, 2 a very good price if we allow for the difference in the value of money, but prices then were entirely dependent on the English seasons; no foreign apples were imported, and a night's frost would treble prices in a day. In I 742 at Aspall Hall, Suffolk, apples, apparently for cider, were Iod. a bushel, in I745 Is. a bushel, in 1746 only $4 d$., and in 1747 cider there was worth $6 d$. a gallon. ${ }^{3}$ At the end of the century, in 'the great hit' of 1784 , common apples were less than $6 d$. a bushel, the best about 2s.; in I786 the price was twice as high, owing to a short crop. Incidentally there is mentioned in the Compleat Cyderman a novel implement, 'a most profitable new invented five-hoe plough, that after the ground has been once ploughed with a common plough will plough four or five acres in one day with only four horses, and by a little alteration is fitted to hoe turnips or rape crops as it is now practised by the ordinary farmers ;' much too favourable an estimate of the ordinary farmer, as Young found horse-hoeing rare.

1 Rural Economy of Gloucestershire (1788), ii. 206.

2 Blundell's Diary, p. 55.

s MS. accounts of Mr. Chevallier, of Aspall Hall. 
An acre of good orchard land at this time was let at $£ 2$ an acre; and this is a fair balance sheet for an acre ${ }^{1}$ :-

Rent of one acre

$$
\text { DR. }
$$$$
£ \text { s. } d \text {. }
$$

Tithe on Io hogsheads, (1) $6 d$.

Gathering, making, and carriage to and from the pound, (1)

35. $6 d$. a hogshead

Racking twice, (1) $6 d$.

Casks and cooperage

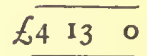

CR.

L s. $d$

Io hogsheads diminished by racking and waste to 8, , I2s. $6 d .500$

Leaving a balance of $7 s$. for spoiling, \&c., so there was not much profit in cider-making then. The same authority sets down the cost of planting an acre of apples as :-

$$
\text { L s. } d \text {. }
$$

132 trees, (1) $2 s$.

(The custom had been to plant 160 trees to the acre, but

this was considered too close.)

Carriage per tree, (a) 2d. ; manure per tree, (1) $3 d_{0}$; planting

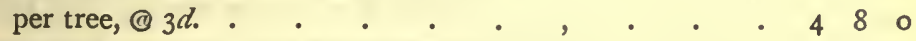

Interest on $£ 17$ 12s. $\mathrm{d}$. for fifteen years before orchard is

profitable, (1) 5 per cent. . . . . . .

Loss of half the rent of the land for the same period, (1) Ios. an

acre

Building cellarage for product per acre

1326

. 7100

500
\[ 4346 \]

For this outlay the landowner would gain an additional rent of $£ I$ a year, so that, according to this authority, growing cider fruit at that time paid neither landlord nor tenant.

1 The Case with the County of Devon with respect to the New Excise Duty on Cider (1763). The duty was 45 . a hogshead, but the opposition was so strong it was taken off. 


\section{CHAPTER XVI \\ $1765-1793$}

ARTHUR YOUNG.-CROPS AND THEIR COST. - THE LABOURERS' WAGES AND DIET. - THE PROSPERITY OF FARMERS.-THE COUNTRY SQUIRE.-ELKINGTON. - BAKEWELL. - THE ROADS.-COKE OF HOLKHAM

THE history of English agriculture in the latter half of the eighteenth century has been so well described by Arthur Young that any account of it at that time must largely be an epitome of his writings. The greatest of English writers on agriculture was born in $174 \mathrm{I}$, and began farming early; but, as he confesses himself, was a complete failure. When he was twenty-six he took a farm of 300 acres at Samford Hall in Essex, and after five years of it paid a farmer $£$ roo to take it off his hands, who thereupon made a fortune out of it. $\mathrm{He}$ had already begun writing on agriculture, and it must be confessed that he began to advise people concerning the art of agriculture on a very limited experience. It paid him, however, much better than farming, for between I 766 and 1775 he realized $£_{3}, 000$ on his works, among which were The Farmers' Letters, The Southern, Northern, and Eastern Tours. These are his qualifications for writing on agriculture, from his own pen: 'I have been a farmer these many years' (he was not yet thirty), ' and that not in a single field or two but upon a tract of near 300 acres most part of the time. I have cultivated on various soils most of the vegetables common in England and many never introduced into field husbandry. I have always kept a minute register of my business in every detail of culture, expenses, and produce, and an accurate com-

${ }^{1}$ Northern Tour, i. 9. For an interesting account of Young, see R.A.S.E. Journal (3rd Series), iv. I. 
parison of the old and new husbandry.' It is said that though he really understood the theory and practice of farming he failed utterly in small economies. He was also far too vivacious and fond of society for the monotonous work of the plain farmer. At the same time his failures gave his observant mind a clear insight into the principles of agriculture. He was indefatigable in inquiries, researches, and experiments ; and the best proof of the value of his works is that they were translated into Russian, German, and French. He tells us in the preface to Rural Economy that his constant employment for the previous seven years, 'when out of my fields, has been registering experiments.' His pet aversions were absentee landlords, obsolete methods of cultivation, wastes and commons, and small holdings (though towards the end of his life he changed his opinion as to the last); and the following, according to him, were the especially needed improvements of the time:-

The knowledge of good rotations of crops so as to do away with fallows, which was to be effected by the general use of turnips, beans, peas, tares, clover, \&c., as preparation for white corn; covered drains; marling, chalking, and claying; irrigation of meadows ; cultivation of carrots, cabbages, potatoes, sainfoin, and lucerne ; ploughing, \&c., with as few cattle as possible; the use of harness for oxen ; cultivation of madder, liquorice, hemp, and flax where suitable. ${ }^{1}$ Above all, the cultivation of waste lands, which he was to live to see so largely effected.

There was little knowledge of the various sorts of grasses at this time, and to Young is due the credit of introducing the cocksfoot, and crested dog's tail.

In 1790 he contemplated retiring to France or America, so heavy was taxation in England. 'Men of large fortune and the poor', he said, in words which many to-day will heartily

1 In 1726 Bradley had urged the use of liquorice, madder, woad, and caraway as improvers of the land in the Preface to the Country Gentleman. 
endorse, 'have reason to think the government of this country the first in the world; the middle classes bear the brunt.' Perhaps to-day 'men of large fortune' have altered their opinion and only 'the poor' are satisfied. However, he only visited France, and gave us his vivid picture of that country before the great revolution.

In I793 the Board of Agriculture was formed, and Young was made secretary with a salary of $£ 400$ a year.

About I 8 Io he wrote that the preceding half-century had been by far the most interesting in the progress of agriculture, and ascribes the increase of interest in it to the publication of his Tours. George III told him he always took with him the Farmer's Letters. The improvement, Young said, had been largely due to individual effort, for commerce had been predominant in Parliament and agriculture had begun to be neglected; a statement which, seeing that Parliament was then almost entirely composed of landowners, must be accepted with some reserve.

Young died in 1820 , having been totally blind for some time, a misfortune which did not prevent him working hard. In his well-known Tours he often had much difficulty in obtaining information, and confesses that he was forced to make more than one farmer drunk before he got anything out of him.

The exodus from the country to the towns then, as so often in history, was noted by thinking people, but Young says it was merely a natural consequence of the demand for profitable employment and was not to be regretted; but he wrote in a time when the country population was still numerous, and there was little danger of England becoming, what she is to-day, a country without a solid foundation, with no reservoir of good country blood to supply the waste of the towns.

When Young began to write, the example of Townshend and his contemporaries was being followed on all sides, and this good movement was stimulated by Young's writings. Farming was the reigning taste of the day. There was scarce 
a nobleman without his farm, most of the country gentlemen were farmers, and attended closely to their business instead of leaving it to stewards, "who governed in matters of wheat and barley as absolutely as in covenants of leases,' and the squire delighted in setting the country a staring at the novelties he introduced. Even the stable and the kennel were ousted by farming from rural talk, ${ }^{1}$ and citizens who breathed the smoke of London five days a week were farmers the other two, and many young fellows of small fortune who had been brought up in the country took farms, and the fashion was followed by doctors, lawyers, clergymen, soldiers, sailors, and merchants. The American and French War of $1775-83$ and the great conflict with France from 1793 to 1815 were, however, to divert many of the upper classes from agriculture, for they very properly thought their duty was then to fight for their country; so that we again have numerous complaints of agents and stewards managing estates who knew nothing whatever about their business. It was not to be wondered at that all this activity brought about considerable progress. 'There have been, 'said Young about I770, 'more experiments, more discoveries, and more general good sense displayed within these ten years than in a hundred preceding ones,' a statement which perhaps did not attach sufficient importance to the work of Townshend and his contemporaries, and to the 'new husbandry' of Tull, which Young did not appreciate at its full value. ${ }^{2}$

The place subsequently taken by the Board of Agriculture, and in our time by the Royal Agricultural Society, was then

1 Rural Economy (1771), pp. 173-5. Trusler, who wrote in 1780, mentions 'the general rage for farming throughout the kingdom.'-Practical Husbandry, p. 1 .

2 In 1780 Sir Thomas Bernard, travelling through Northumberland, saw 'luxuriant plantations, neat hedges, rich crops of corn, comfortable farm-houses' in a county whereof the greater part was barren moor dearly rented at Is. $6 d$. an acre thirty years before, and he said the county had increased in annual value fourfold. (Contemporary MS., unpublished.) 
occupied by the Society for the Encouragement of Arts, Manufactures, and Commerce, which offered premiums for such objects as the cultivation of carrots in the field for stock, then little practised; for gathering the different sorts of grass seeds and keeping them clean and free from all mixture with other grasses, a very rare thing at that time; for experiments in the comparative merits of the old and new husbandry; for the growth of madder; $£ 20$ for a turnip-slicing machine, then apparently unknown, and for experiments whether rolling or harrowing grass land was better, 'at present one of the most. disputed points of husbandry.'

In spite of this progress, many crops introduced years before were unknown to many farmers. Sainfoin, cabbages, potatoes, carrots, were not common crops in every part of England, though every one of them was well known in some part or other; not more than half, or at most two-thirds, of the nation cultivated clover. Many, however, of the nobility and gentry in the north had grown cabbages with amazing success, lately, 30 guineas an acre being sometimes the value of the crop.

Half the cultivated lands, in spite of the progress of enclosure for centuries, were still farmed on the old common-field system. When anything out of the common was to be done on common farms, all common work came to a standstill. 'To carry out corn stops the ploughs, perhaps at a critical season; the fallows are frequently seen overrun with weeds because it is seed time; in a word, some business is ever neglected.' 1 As for the outcry against enclosing commons and wastes, people.forgot that the farmers as well as the poor had a right of common and took special care by their large number of stock to starve every animal the poor put on the common. ${ }^{2}$

About the same time that Young wrote these words there appeared a pamphlet written by 'A Country Gentleman' on the advantages and disadvantages of enclosing waste lands and common fields, which puts the arguments against en-

1 Rural Economy, p. 26.

2 Farmer's Letters (3rd ed.), p. 89. 
closure very forcibly. The writer's opinion was that it was clearly to the landowner's gain to promote enclosures, but that the impropriator of tithes reaped most benefit and the small freeholder least, because his expenses increased inversely to the smallness of his allotment. As to diminution of employment, he reckoned that enclosed arable employed about ten families per $\mathrm{I}, 000$ acres, open field arable twenty families, a statement opposed to the opinion of nearly all the agricultural writers of the seventeenth and eighteenth centuries. It is surely an incontestable fact that enclosed land meant much better tillage, and better tillage meant more labour, the excessive amount of fallow necessary under the common-field system, from the inability to grow roots except by special arrangement, is alone enough to prove this. The same writer admitted that common pastures, wastes, \&c., employed only one family per 2,000 acres, but enclosed pasture five families per 1,000 acres, and enclosed wastes sixteen families.

A 'Country Farmer', who wrote in 1786 , states that many of the small farmers displaced by enclosures sold their few possessions and emigrated to America. ${ }^{2}$ The growing manufacturing towns also absorbed a considerable number. That there was a considerable amount of hardship inflicted on small holders and commoners is certain, but industrial progress is frequently attended by the dislocation of industry and consequent distress; the introduction of machinery, for instance, often causing great suffering to hand-workers, but eventually benefiting the whole community. How many men has the self-binding reaping machine thrown for a time out of work? So enclosure caused distress to many individuals, but was for the good of the whole nation. The history of enclosure is really the history of progress in farming; the conversion of land badly tilled in the old common fields, and of waste

${ }^{1}$ Slater, English Peasantry and Enilosure, p. 95.

2 Ibid. p. IOI. 
land little more valuable than the prairies, into well-managed fruitful farms. That much of the common-field land when enclosed was laid down to grass is certainly true, and certainly inevitable if it paid best under grass. ${ }^{1}$ No one can expect the holders of land naturally best suited for grass to keep it under tillage for philanthropic purposes. A vast number of the commoners too were idle thriftless beings, whose rights on a few acres enabled them to live a life of pilfering and poaching; and it was a very good thing when such people were induced to lead a more regular and respectable existence. The great blot on the process was that it made the English labourer a landless man. Compensation was given him at the time of enclosure in the shape of allotments or sums of money, but the former he was generally compelled to give up owing to the expense he had been put to at allotment, and the latter he often spent in the public-house.

At this date the proprietors of large estates who wished tor enclose by Act of Parliament, generally settled all the particulars among themselves before calling any meeting of the rest of the proprietors. The small proprietor had very little say either in regulating the clauses of the Act, or in the choice of commissioners. Any owner of one-fifth of the land, however, could negative the measure and often used his right to impose unreasonable clauses. It is well known that the legal expenses and fencing were very costly. The enclosure commissioners too often divided the land in an arbitrary and ignorant manner, and there was no appeal from them except by filing a bill in Chancery. Accounts were hardly ever shown by the commissioners, and if a proprietor refused to pay the sums levied they were empowered to distrain immediately.

1 Young, Northern Tour, iv. 340, about 1770 estimates the cultivated land of England to be half pasture and half arable, and, in the absence of reliable statistics, his opinion on this point is certainly the best available. The conversion of a large portion of the richer land from arable to grass in the eighteenth century was compensated for, according to Young, by the conversion, on enclosure, of poor sandy soils and heaths or moors into corn land. Hasbach, op. cit. pp. 370-1. 
All these evils attending enclosure made many who were eager to benefit by it very chary in commencing it. ${ }^{1}$

Then, as now, one of the commonest errors of farmers was that of taking too much land for their capital; Young considered $£ 6$ an acre necessary on an average, equal to more than $£ 12$ to-day; a sum which few farmers at any time have in hand when they take a farm. As for gentlemen farmers, who were then rushing into the business, they were warned that they had no chance of success if they kept any company or amused themselves with anything but their own business, unless perhaps they had a good bailiff.

Lime, one of the most ancient of manures, was then the most commonly used in England, 80 to roo loads an acre being a common dressing, but many farmers were very ignorant of its proper use. Marl, which to-day is seldom used, was considered to last for twenty years, though for the first year no benefit was observable, and very little the second and the third, its value then becoming very apparent. In the last five years, however, its value was nearly worn out. But it was much to be questioned whether marl in its best state anywhere yields an increase of produce equal to that which a good manuring of dung will give. ${ }^{2}$ Marl was applied in huge quantities on arable and grass, and often made the latter look like arable land so thickly was it spread.

At this date ( 1770 ) the average crops on poor, and on good land were ${ }^{3}$ :

On land worth 5s. an acre:

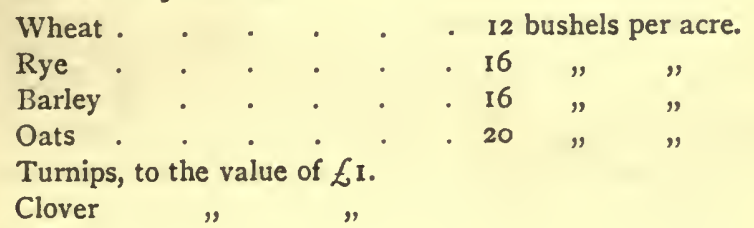

1 Young, Northern Tour, i. 222.

2 Rural Economy, p. 252.

3 Ibid. p. 27 I. 
On land worth 20s, an acre:

Wheat . . . . 28 bushels per acre.

Barley . . . . 40 " "

Oats . . . . . . 48 , "

Beans . . . . . 40 " "

Turnips, to the value of $£ 3$.

Clover

s)

The cost of cultivating the latter, which may be given in full, as it affords an excellent example of the price of growing various crops, and the methods of their cultivation at this period, was as follows:

First year, turnips :

$$
£ \text { s. } d \text {. }
$$

Ren

Tithe and 'town charges' . . . . . 80

Five ploughings, @ 4 s. . . . . . I 00

Three harrowings.$+\quad . \quad . \quad$. $\quad$ I 0

Seed . . . . . . . . . . 6

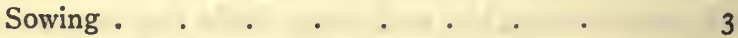

Twice hand-hoeing . . . . 70

$£ 216 \quad 9$

It will be noticed there was no horse-hoeing.

Second year, barley :

Es. d.

Rent, tithe, \&c.

Three ploughings

Three harrowings

Seed

Sowing .

Mowing and harvesting

Water furrowing

Threshing, @ Is. a quarter

Third year, clover :

Rent, \&c.

Seed

Sowing
I 80

120

I 0

80

3

30

6

50

$\lcm{2} 179$

$E$ s. $d$.

I 80

50 
Fourth year, ${ }^{1}$ wheat:

Rent, \&c.

One ploughing

Three harrowings

Seed

Sowing

Water furrowing .

Thistling

Reaping and harvesting

Threshing, @ 2s. a quarter .

Fifth year, beans :

Rent, \&c.

Two ploughings

Seed, 2 bushels

Sowing

Twice hand-hoeing

Twice horse-hoeing

Reaping and harvesting

Threshing

Sixth year, oats :

Rent, \&c.

Once ploughing

Two harrowings

Four bushels of seed

Sowing

Mowing and harvesting

Threshing,@ @s. a quarter

$$
\begin{aligned}
& £ \text { s. } d \text {. } \\
& \text { I } 80 \\
& 40 \\
& 10 \\
& 100 \\
& 3
\end{aligned}
$$

\begin{tabular}{rrr}
1 & 8 & 0 \\
8 & 0 \\
8 & 0 \\
& 6 \\
12 & 0 \\
3 & 0 \\
8 & 0 \\
5 & 0 \\
\hline$£ 312$ & 6 \\
\hline
\end{tabular}

\begin{tabular}{rrr}
1 & 8 & 0 \\
4 & 0 \\
& 8 \\
6 & 0 \\
& 3 \\
3 & 0 \\
& 6 & 0 \\
\hline${ }_{2}$ & 7 & 11 \\
\hline
\end{tabular}

Good land at a high rent is always better than poor land at a low rent; the average profit per acre on $5 \mathrm{~s}$. land was then about $8 s .8 d$., on $20 s$. land, $29 s$.

Grass was-much more profitable than tillage, the profit on I 20 acres of arable in nine years amounted to $£ 88$, whereas on grass it was $£ 212$, or $9 s .9 d$. an acre per annum for the former and $23 s$. for the latter. ${ }^{2}$ Yet dairying, at all events, was then

${ }^{1} \mathrm{Cf}$. above, p. 180 .

'Farmer's Letters (3rd ed), p. 372. 
on the whole badly managed and unprofitable. The average cow ate $2 \frac{1}{2}$ acres of grass, and the rent of this with labour and other expenses made the cost $£ 5$ a year per cow, and its average produce was not worth more than $£_{5} 6 s .3 d^{1}$ This scanty profit was due to the fact that few farmers used roots, cabbages, \&c., for their cows, and to their wrong management of pigs, kept on the surplus dairy food. By good management the nett return could be made as much as $£ 4$ I.5s. od. per cow.

The management of sheep in the north of England was wretched. In Northumberland the profit was reckoned at is. a head, partly derived from cheese made from ewes' milk. The fleeces averaged $2 \mathrm{lb}$., and the wool was so bad as not to be worth more than $3 d$. or $4 d$. per $1 \mathrm{~b} .^{2}$

Pigs could be made to pay well, as the following account testifies :

Food and produce of a sow in one year (1763), which produced seven pigs in April and eleven in October:

$$
\text { DR. } £ \text { s. } d \text {. }
$$

Grains

Cutting a litter

\section{5 quarters peas}

Io 4 A pig.

CR.

E. s. $d$.

ro bushels barley

Expenses in selling ${ }^{3}$ Io bushels peas

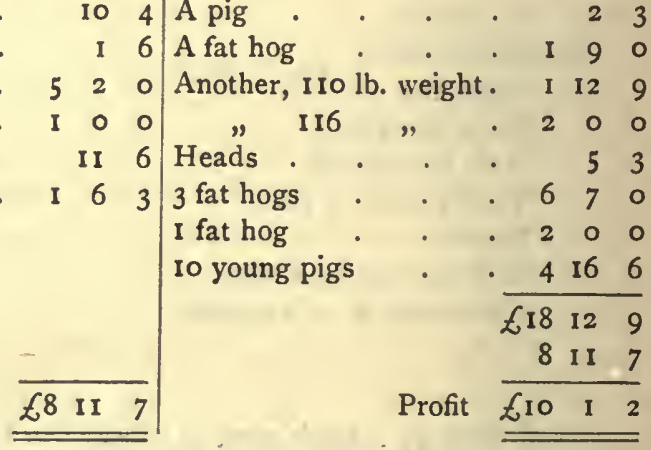

We have seen that Young thought little of the 'new husbandry'; he does not even give Tull the credit of inventing the drill: : Mr. Tull perhaps again invented it. He practised it

1 Northern Tour, iv. 167.

2 Ibid. iv. 186.

3 This large item is explained by the fact that a bailiff was employed to sell, and no bailiff could find customers 'without feeling the same drought as stage coachmen when they see a sign'.-Young, Farmer's Letters, p. 403. 
upon an extent of ground far beyond that of any person preceding him: the spirit of drilling died with Mr. Tull and was not revived till within a few years.' 1 It was doubtful if 50 acres of corn were then annually drilled in England. Lately drilling had been revived and there were keen disputes as to the old and new methods of husbandry, the efficacy of the new being far from decided. The cause of the slow adoption of drill husbandry was the inferiority of the drills hithertd invented. They were complex in construction, expensive, and hard to procure. It seemed impossible to make a drill or drill plough as it was called, for such it then was-a combination of drill, plough, and harrow-capable of sowing at various depths and widths, and at the same time light enough for ordinary use. All the drills hitherto made were too light to stand the rough use of farm labourers: 'common ploughs and harrows the fellows tumble about in so violent a manner that if they were not strength itself they would drop to pieces. In drawing such instruments into the field the men generally mount the horses, and drag them after them ; in passing gateways twenty to one they draw them against the gate post.' Some of 'these fellows' are still to be seen !

Another defect in drilling was that the drill plough filled up all the water furrows, which, at a time when drainage was often neglected, were deemed of especial importance, and they all had to be opened again.

Further, said the advocates of the old husbandry, it was a question whether all the horse-hoeings, hand-hoeings, and weedings of the new husbandry, though undoubtedly beneficial, really paid. It was very hard to get enough labourers for these operations. With more reason they objected to the principles of discarding manure and sowing a large number of white straw crops in succession, but admitted the new system was admirably adapted for beans, turnips, cabbages, and lucerne.

However, there were many followers of Tull. The author of Dissertations on Rural Subjects ${ }^{2}$ thought the drill plough an 
excellent invention, as it saved seed and facilitated hoeing; but he said Tull's drill was defective in that the distances between the rows could not be altered, a defect which the writer claims to have remedied. Young's desire for a stronger drill seems to have been soon answered, as the same writer says the barrel drill invented by Du-Hamel and improved by Craik was strong, cheap, and easily managed.

The tendency of the latter half of the century was decidedly in favour of larger farms; it was a bad thing for the small holders, but it was an economic tendency which could not be resisted. The larger farmers had more capital, were more able and ready to execute improvements; they drained their land, others often did not; having sufficient capital they were able both to buy and sell to the best advantage and not sacrifice their produce at a low price to meet the rent, as the small farmer so often did and does. They could pay better wages and so get better men, kept more stock and better, and more efficient implements. They also had a great advantage in being able by their good teams to haul home plenty of purchased manure, which the small farmer often could not do. The small tenants, who had no by-industry, then, as now, had to work and live harder than the ordinary labourer to pay their way.

Young calculated as early as I768 that the average size of farms over the greater part of England was slightly under 300 acres. $^{1}$

In his Tour in France Young, speaking of the smallness of French farms as compared with English ones, and of the consequent great inferiority of French farming, says, "Where is the little farmer to be found who will cover his whole farm with marl at the rate of IOO to I 50 tons per acre; who will drain his land at the expense of $£_{2}$ to $£_{3}$ an acre; who will, to improve the breed of his sheep, give $I, 000$ guineas for the use of a single ram for a single season; who will send across the kingdom to distant provinces for new implements and for 
men to use them? Deduct from agriculture all the practices that have made it flourishing in this island, and you have precisely the management of small farms.' In 1868 the Report of the Commission on the Agriculture of France ${ }^{1}$ agreed with Young, noting the grave consequences of the excessive subdivision of land, loss of time, waste of labour, difficulties in rotation of crops, and of liberty of cultivation.

For stocking an arable farm of 70 acres Young considered the following expenditure necessary, the items of which give us interesting information as to prices about 1770 :-

Rent, tithe, and town charges for first year . $\quad 70 \circ \circ$

Household furniture . . . . . . . $30 \circ 0$

Wagon . . . . . . . . . 2500

Cart with ladders . . . . . . . . 1200

Tumbril . . . . . . . . 10 . 0

Roller for broad lands (of wood) . . . . 200

" narrow " $"$. . . . I I5 O

Cart harness for 4 horses . . . . 8170

Plough " . . . . . . . . 2160

2 ploughs . . . . . . . . . 300

A pair of harrows . . . . . . . 15150

Screen, bushel, fan, sieves, forks, rakes, \&c. . . 8 . 8

Dairy furniture . . . . . . . . $3 \circ 0$

20 sacks . . . . . . . . 2100

4 horses . . . . . . . . 3200

Wear and tear, and shoeing one year . . . $13 \circ 0$

Keep of 4 horses from Michaelmas to May Day, @

2s. $6 d$. each a week . . . . . . $14 \circ 0$

5 cows

20 sheep

One sow

One servant's board and wages for one year . . I5 00

A labourer's wages for one year . . . . 2000

Seed for first year, 42 acres, @ IIs. $6 d . \quad$. . . 2430

Harvest labour . . . . . . . . I I0 0

$£ 326$ I1 0

Or nearly $£ 5$ an acre.

${ }^{1}$ See Parliamentary Reports Commission (188I), xvi. 260. 
About the same date the Complete English Farmer reckoned that the occupier of a farm of 500 acres (300 arable, 200 pasture), ought to have a capital of $£ 1,500$, and estimated that, after paying expenses and maintaining his family, he could put by $£ 50$ a year; 'but this capital was much beyond what farmers in general can attain to.'

The controversy of horses versus oxen for working purposes was still raging, and Young favoured the use of oxen; for the food of horses cost more, so did their harness and their shoeing, they are much more liable to disease, and oxen when done with could be sold for beef. One stout lad, moreover, could attend to 8 or Io oxen, for all he had to do was to put their fodder in the racks and clean the shed; no rubbing, no currying or dressing being necessary. No beasts fattened better than oxen that had been worked. A yolke of oxen would plough as much as a pair of horses and carry a deeper and truer furrow, while they were just as handy as horses in wagons, carts, rollers, \&c. William Marshall, the other great agricultural writer of the end of the eighteenth century, agreed with Young, yet in spite of all these advantages horses were continually supplanting oxen.

Among the improvements in agriculture was the introduction of broad-wheeled wagons; narrow-wheeled ones were usual, and these on the turnpikes were only allowed to be drawn by 4 horses so that the load was small, but broad-wheeled wagons might use 8 horses. The cost of the latter was $£ 5^{\circ}$ against $£^{2} 5$ for the former. ${ }^{2}$

Young's opinion of the labouring man, like Tull's, was not a high one. 'I never yet knew', he says, 'one instance of any poor man's working diligently while young and in health to escape coming to the parish when ill or old.' This is doubtless too sweeping. There must have been others like George Barwell, whom Marshall tells of in his Rural Economy of the Mid-

1 Dissertations on Rural Subjects, p. 278.

2 Farmer's Letters, p. 433. 
lands, who had brought up a family of five or six sons and daughters on a wage of $5 s$. to $7 s$. a week, and after they were out in the world saved enough to support him in his old age. The majority, however, long before the crushing times of the French War, seen to have been thoroughly demoralized by indiscriminate parish relief, and habitually looked to the parish to maintain them in sickness and old age. Cullum, ${ }^{1}$ a few years later, remarks on the poor demanding assistance without the scruple and delicacy they used to have, and says "the present age seems to aim at abolishing all subordination and dependence and reducing all ranks as near a level as possible.'! Idleness, drunkenness, and what was then often looked on with disgust and contempt, excessive tea-drinking, were rife. Tea then was very expensive, $8 s$. or Ios. a lb. being an ordinary price, so that the poor had to put up with a very much adulterated article, most pernicious to health. The immoderate use of this was stated to have worse effects than the immoderate use of spirits. The consumption of it was largely caused by the deficiency of the milk supply, owing to the decrease of small farms; the large farmers did not retail such small commodities as milk and butter, but sent them to the towns so that the poor often went without. ${ }^{2}$

In 1767 Young found wages differing according to the distance from London ${ }^{3}$ :-

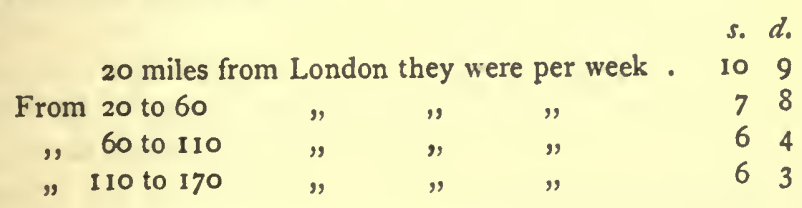

Giving an average of $7 s .9 d$. which, however, was often

1 History of Hawsted, p. 169.

2 Hasbach, op. cit. p. 127 ; Kent, Hints to Gentlemen, p. 152.

3 Southern Tour, p. 324. He says nothing of the manufacturing towns. which had not yet begun to influence the wages of farm labourers near them as they soon afterwards did. 
exceeded as there was much piece-work which enabled the men to earn more.

Young drew up a dietary for a labourer, his wife, and a family of three children, which he declared to be sufficient :-

$£$ s. $d$.

Food, 6s. per week ${ }^{2}$; per year . . . . I5 120

Rent

Clothes

Soap and candles

Loss of time through illness, and medicine.

Fuel

$$
\begin{aligned}
& 1100 \\
& 2100 \\
& \text { - } 150 \\
& \text { - } 100 \\
& \begin{array}{r}
200 \\
£ 23170 \\
\hline
\end{array}
\end{aligned}
$$

The man's wages were, @ Is. $3 d$. a day, for the year I9 10 0

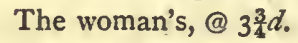

The boy of fifteen could earn . . . . 900

The boy of ten could earn . . . . 476

$£ 37$ 15 0

Which would give the family a surplus of $f_{1} \mathrm{I}_{3} \mathrm{I} 8$ s. od. a year. What the man's food should consist of is shown by a list of 'seven days' messes for a stout man ':-

Ist day. $2 \mathrm{lb}$. of bread made of wheat, rye, and potatoes-

$$
\text { s. } d \text {. }
$$

' no bread exceeds it'

Cheese, 2 oz. @ 4d. a lb.

Beer, 2 quarts

2nd "Three messes of soup

3rd "Rice pudding .

4 th $" \frac{1}{4} \mathrm{lb}$. of fat meat and potatoes baked together

Beer

5th ", Rice milk

6th "Same as first day

7 th "Potatoes, fat meat, cheese, and beer

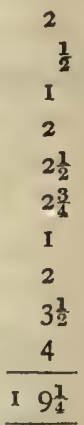

As Young was a man of large practical experience we may

1 Some prices-at this time were : bread per $1 \mathrm{~b}$., $2 d$.; butter, $5 \frac{1}{2} d$. to $8 d$. ; cheese, $3 \frac{1}{2} d$. to $4 d$. ; beef, $3 d$. to $5 d$.; mutton, $3 \frac{1}{2} d$. to $5 d$. 
assume that this, though it seems a very insufficient diet, was not unlike the food of some labourers at that date. However, the bread he recommends was not that eaten by a large number of them. Eden ${ }^{1}$ states that in 1764 about half the people of England were estimated to be using wheaten bread, and at the end of the century, although prices had risen greatly, he says that in the Home Counties wheaten bread was universal among the peasant class. Young, indeed, acknowledges that many insisted on wheaten bread. ${ }^{2}$ In Suffolk, according to Cullum, ${ }^{3}$ pork and bacon were the labourer's delicacies, bread and cheese his ordinary diet.

The north of England was more thrifty than the south. At p the end of the eighteenth century barley and oaten bread were much used there. Lancashire people fed largely on oat bread, leavened and unleavened; the 33 rd Regiment, which went by the name of the 'Havercake lads', was usually recruited from the West Riding where oat bread was in common use, and was famous for having fine men in its ranks. ${ }^{4}$ The labourers of the north were also noted for their skill in making soups in which barley was an important ingredient. In many of the southern counties tea was drunk at breakfast, dinner, and supper by the poor, often without milk or sugar ; but alcoholic liquors were also consumed in great quantities, the southerner apparently always drinking a considerable amount, the northerner at rare intervals drinking deep. The drinking in cider counties seems always to have been worse as far as quantity goes than elsewhere, and the drink bills on farms were enormous. Marshall says that in Gloucestershire drinking a gallon 'bottle', generally a little wooden barrel, at a draught was no uncommon feat; and in the Vale of Evesham a labourer who

1 State of the Poor, i. 562.

2 According to Walter Harte, though the yeoman in the middle of the seventeenth century ate bread of rye and barley (maslin), in 1766 even the poor cottagers looked upon it with horror and demanded best wheaten bread. Yet in 1766 the quartern loaf in London was 1 s. $6 d . !-$ Tooke, History of Prices, i. 68.

3 History of Hawsted, p. I84.

- Eden, State of the Poor, i. 513. 
wanted to be even with his master for short payment emptied a two-gallon bottle without taking it from his lips. Even this feat was excelled by 'four well-seasoned yeomen, who resolved to have a fresh hogshead tapped, and setting foot to foot emptied it at one sitting.' 1 Yet in the beer-drinking counties great quantities were consumed; a gallon a day per man all the year round being no uncommon allowance. ${ }^{2}$

The superior thrift of the north was shown in clothes as well as food, the midland and southern labourer at the end of the century buying all his clothes, the northerner making them almost all at home; there were many respectable families in the north who had never bought a pair of stockings, coat, or waistcoat in their lives, and a purchased coat was considered a mark of extravagance and pride.

Perhaps the most remarkable feature of Young's dietary is that green vegetables are absolutely ignored. The peasant was supposed to need them as little as in the Middle Ages.

However, Young admits that very few labourers lived as cheaply as this, and he found the actual ordinary budget for the same family to be:-

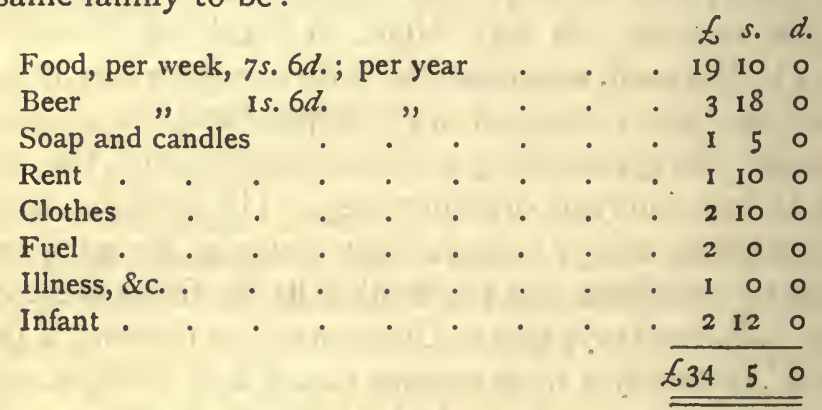

This, with the same income as before, left him with a surplus of $£_{3}$ los. od.; but as it was not likely his wife could work all the year round, or that both his eldest children should be boys, it appears that his expenses must often have exceeded his

1 Rural Economy of Gloucestershire, i. 53.

Eden, op. cit. i. 547. 
income. This being so, it is not surprising that he was often drunken and reckless, and ready to come on the parish for relief. To labour incessantly, often with wife and boys, to live very poorly, yet not even make both ends meet, was enough to kill all spirit in any one.

A great evil from which the labourer suffered was the restrictions thrown on him of settling in another parish. If he desired to take his labour to a better market he often found it closed to him. His marriage was discouraged, ${ }^{1}$ because a single man did not want a cottage and a married one did. To ease the rates there was open war against cottages, and many were pulled down. ${ }^{2}$ If a labourer in a parish to which he did not legally belong signified his intention of marrying, he immediately had notice to quit the parish and retire to his own, unless he could procure a certificate that neither he nor his would be chargeable. If he went to his own parish he came off very badly, for they didn't want him, and cottages being scarce he probably had to put up with sharing one with one or more families. Sensible men cried out for the total abolition of the poor laws, the worst effects of which were still to be felt.

Yet there was a considerable migration of labour at harvest time when additional hands were needed. Labourers came from neighbouring counties, artisans left their workshops in the towns, Scots came to the Northern counties, Welshmen to the western, and Irishmen appeared in many parts; and they were as a rule supplied by a contractor. ${ }^{3}$

London was regarded as a source of great evil to the country by attracting the young and energetic thither. It used, men

\section{Farmer's Letters, i. 300.}

2 The pulling down of cottages began to be complained of in the seventeenth century; they harboured the poor, who were a charge upon the parish, and repairs were saved.-Transactions Royal Historical Society (New Series), xix. I20.

3 Hasbach, op. cit. 82; Clarke, General View of Herefordshire, p. 29; Marshall, Review of Northern Department, p. 375. 
said, to be no such easy matter to get there when a stage coach was four or five days creeping Ioo miles and fares were high; but in 1770 a country fellow 100 miles from London jumped on a coach in the morning and for $8 \mathrm{~s}$. or Ios. got to town by night, "and ten times the boasts are sounded in the ears. of country fools by those who have seen London to induce them to quit their healthy clean fields for a region of dirt, stink, and noise.' A prejudice might well have been entertained against the metropolis at this time, for it literally devoured the people of England, the deaths exceeding the births by 8,000 a year. One of the causes that had hitherto kept people from London was the dread of the small-pox, but that was now said to be removed by inoculation. Among the troubles farmers had to contend with were the audacious depredations caused by poachers, generally labourers, who swarmed in many villages. They took the farmer's horses out of his fields after they had done a hard day's work and rode them all night to drive the game into their nets, blundering over the hedges, sometimes staking the horses, riding over standing corn, or anything that was cover for partridges, and when they had sold their ill-gotten game spent the money openly at the nearest alehouse. Then they would go back and work for the farmers they had robbed, drunk, asleep, or idle the whole day. The subscription packs of foxhounds were also a great nuisance, many of the followers being townsmen who bored through hedges and smashed the gates and stiles, conduct not unknown to-day. In spite of these drawbacks the long period of great abundance from I7I5 to $I_{7} 65$ and the consequent cheapness of food with an increase of wages was attended with a great improvement in the condition and habits of the people. Adam Smith refers to 'the peculiarly happy circumstances of the country'; Hallam described the reign of George II as 'the most prosperous period that England has ever experienced'1; and it was Young's opinion about 1770 that

1 Tooke, History of Prices, i. 50; Hallam, Constitutional History, iii. 302. 
England was in a most rich and flourishing situation, 'her agriculture is upon the whole good and spirited and every day improving, her industrious poor are well fed, clothed, and lodged at reasonable rates, the prices of all necessaries being moderate, our population increasing, the price of labour generally high.' 1 The great degree of luxury to which the country had arrived within a few years 'is not only astonishing but almost dreadful to think of. Time was when those articles of indulgence which now every mechanic aims at the possession of were enjoyed only by the baron or lord.' ${ }^{2}$ Great towns became the winter residence of those who could not afford London, and the country was said to be everywhere deserted, an evil largely attributed to the improvement of posting and coaches. The true country gentleman was seldom to be found, the luxuries of the age had softened down the hardy roughness of former times and the "country, like the capital, is one scene of dissipation.' The private gentleman of $£ 300$ or $£ 400$ a year must have his horses, dogs, carriages, pictures, and parties, and thus goes to ruin. The articles of living, says the same writer, were roo per cent. dearer than some time back. This is a very different picture from that in which Young represents every one rushing into farming, but no doubt depicts one phase of national life.

An excellent observer ${ }^{3}$ noticed in 1792 that the preceding forty or fifty years had witnessed the total destruction in England of the once common type of the small country squire. He was :-

'An independent gentleman of $£ 300$ per annum who commonly appeared in a plain drab or plush coat, large silver buttons, a jockey cap, and rarely without boots. His travels

1 Northern Tour, iv. 420. The increase of population in the first half of the eighteenth century was slow; after the Peace of Paris in 1763 , when the commerce and manufactures of the country were extended in an unprecedented degree, it was rapid.

2 The Way to be Rich and Respectable, London, 1780.

3 Grose, Olio, pp. 41-4; Lecky, History of England in Eighteenth Century, vi. 169 et seq. 
never exceeded the distance of the county town, and that only at assize or session time, or to attend an election. Once a week he commonly dined at the next market town with the attorneys and justices. He went to church regularly, read the weekly journal, settled the parochial disputes, and afterwards adjourned to the neighbouring alehouse, where he generally got drunk for the good of his country. He was commonly followed by a couple of greyhounds and a pointer, and announced his arrival at a neighbour's house by smacking his whip and giving a view halloo. His drink was generally ale, except on Christmas Day, the Fifth of November, or some other gala day, when he would make a bowl of strong brandy. The mansion of one of these squires was of plaster striped with timber, not unaptly called callimanco work, or of red brick with large casemented bow windows; a porch with seats in it and over it a study: the eaves of the house well inhabited by swallows, and the court set round with hollyhocks; near the gate a horse-block for mounting. The hall was furnished with flitches of bacon, and the mantelpiece with guns and fishing-rods of different dimensions, accompanied by the broadsword, partisan, and dagger borne by his ancestor in the Civil Wars. Against the wall was posted King Charles's Golden Rules, Vincent Wing's Almanac and a portrait of the Duke of Marlborough; in his window lay Baker's Chronicle, Foxe's Book of Martyrs, Glanvill On Apparitions, Quincey's Dispensatory, The Complete Justice, and a Book of Farriery. In a corner by the fireside stood a large wooden two-armed chair with a cushion, and within the chimney corner were a couple of seats. Here at Chrismas he entertained his tenants, assembled round a glowing fire made of the roots of trees; and told and heard the traditionary tales of the village about ghosts and witches while a jorum of ale went round. These men and their houses are no more.'

The farmer, in some parts at all events, was becoming a more civilized individual; the late race had lived in the midst of their enlightened neighbours like beings of another order ${ }^{1}$; in their personal labour they were indefatigable, in their fare hard, in their dress homely, in their manners rude. The Frençh and American War of $1775^{-8} 3$ was a very prosperous

1 Cullum, History of Hazested, p. 219. 
time, and the farmer's mode of living greatly improved. Farm-, houses in England, it was noticed, were in general well furnished with every convenient accommodation. Into many of them a 'barometer had of late years been introduced'. The teapot and the mug of ale jointly possessed the breakfast table, and meat and pudding smoked on the board every noon. Formerly one might see at church what was the cut of a coat half a century ago, now dress was spruce and modern. ${ }^{1}$ As a proof of the spirit of improvement among farmers, Marshall instances the custom in the Midlands of placing their sons as pupils on other farms to widen their experience. "Their entertainments are as expensive as they are elegant, for it is no uncommon thing for one of these new-created farmers to spend $£ 10$ or $£ 12$ at one entertainment, and to have the most expensive wines; to set off the entertainment in the greatest splendour an elegant sideboard of plate is provided in the newest fashion.' ${ }^{2}$ As to dress, no one could tell the farmer's daughter from the duke's. Marshall noticed that in Warwickshire the harness of the farmer's teams was often ridiculously ornamented, and the horses were overfed and underworked to save their looks. Before enclosure the farmer entertained his friends with bacon fed by himself, washed down with ale brewed from his own malt, in a brown jug, or a glass if he ivas extravagant. He wore a coat of woollen stuff, the growth of his own flock, spun by his wife and daughters, his stockings came from the same quarter, so did the clothes of his family.

Some of these farmers were doing their share in helping the progress of agriculture. In 1764 Joseph Elkington, of Princethorpe in Warwickshire, was the first to practise the under drainage of sloping land that was drowned by the bursting of springs. He drained some fields at Princethorpe which were very wet, and dug a trench 4 or 5 feet deep for this purpose;

1 Cullum, History of Harested, p. 225.

2 Thoughts on Enclosure, by a Country Farmer (1786), p. 21. 
but finding this did not reach the principal body of subjacent water, he drove an iron bar 4 feet below the bottom of his trench and on withdrawing it the water gushed out. He was thus led to combine the system of cutting drains, aided when necessary by auger holes. His main principles were three: (I) Finding the main spring, or cause of the mischief. (2) Taking the level of that spring and ascertaining its subterranean bearings, for if the drain is cut a yard below the line of the spring the water issuing from it cannot be reached, but on ascertaining the line by levelling the spring can be cut effectually. (3) Using the auger to tap the spring when the drain was not deep enough for the purpose. ${ }^{1}$ It was owing to the Board of Agriculture at the end of the century that he obtained the vote of $£ \mathrm{I}, 000$ from Parliament, and a skilful surveyor was appointed to observe his methods and give them to the public, for he was too ignorant himself to give an intelligible account of his system. After the publication of the report his system was followed generally until Smith of Deanston in 1835 gave the niethod now in use to his country.

Robert Bakewell, who did more to improve live stock than any other man, was born at Dishley, Leicestershire, in 1725 , and succeeding to the management of his father's farm in 1760 began to make experiments in breeding. ${ }^{2}$ He scorned the old idea that the blood must be constantly varied by the mixture of different breeds, and his new system differed from the old in two chief points: (I) small versus large bone, and consequently a greater proportion of flesh and a greater tendency to fatten; (2) permissible inbreeding versus perpetual crossing with strange breeds. He took immense pains in selecting the best animals to breed from, and had at Dishley a museum of skeletons and pickled specimens for the comparison of one generation with another, and he conducted careful post-mortem examinations

1 Johnstone, Account of Elkington's Draining (1797), pp. 8-9.

2 R.A.S.E. Journal (1894), p. 11 , from which this account of Bakewell is mainly taken. 
on his stock. His great production was the new Leicester breed of sheep, ${ }^{1}$ which in half a century spread over every part of the United Kingdom, as well as to Europe and America, and gave England $2 \mathrm{lb}$. of meat where she had one before. Sheep at this time were divided into two main classes: (I) shortwoolled or field sheep, fed in the open fields; (2) long-woolled or pasture sheep, fed in enclosures. That they were not at a very high state of perfection may be gathered from this description of the chief variety of the latter, the 'Warwickshire' breed: 'his frame large and loose, his bones heavy, his legs long and thick, his chine as well as his rump as sharp as a hatchet, his skin rattling on his ribs like a skeleton covered with parchments.' The origin of the new Leicester sheep is uncertain, but apparently the old Lincoln breed was the basis of it, though this, like other large breeds of English sheep, was itself an introduction of the last half century. The new sheep was described as having a clean head, straight broad flat back, barrel-like body, fine small eyes, thin feet, mutton fat, fine-grained and of good flavour, wool $8 \mathrm{lb}$. to the fleece, and wethers at two years old weighed from 20 to $30 \mathrm{lb}$. a quarter.

By 1770 his rams were hired for 25 guineas a season, and soon after he made $£ 3,000$ a year by their hire, one named 'Two-pounder' bringing him I,200 guineas in one year.

One of his theories was that the poorer the land the more it demanded well-made sheep, which is no doubt true to a certain extent; but it has been proved conclusively since that the quality of the breed gradually drops to the level of the land unless artificially assisted. At his death he left two distinct breeds of sheep, for he improved on his own new Leicester, so that the improved became the 'New Leicester' and the former the 'Old Leicester.' However, at the time

1 According to some, Joseph Allom originated the breed, and Bakewell vastly improved it. We may safely give the chief credit to so careful and gifted a breeder as Bakewell. 
and, afterwards, his sheep were generally called 'New Leicesters', and sometimes the 'Dishley breed'. There was much prejudice among farmers against the new breed; in the Midlands most of the farmers would have nothing to do with them, and 'their grounds were stocked with creatures that would disgrace the meanest lands in the kingdom.' Yet in April, r786, yearling wethers of the new breed were sold for $28 \mathrm{~s}$. while those of the old were $16 s$.

The cattle which he set to work to improve were the famous old longhorn breed, the prevailing breed of the Midlands, which had already been considerably improved by Webster of Canley in Warwickshire, and others, especially in Lancashire and the north. The kind of cattle esteemed hitherto had been 'the large, long-bodied, big-boned, coarse, flat-sided kind, and often lyery or black-fleshed.' 1 He founded his herd upon two heifers of Webster's and a bull from Westmoreland, and from these bred all his cattle. The celebrated bull 'Twopenny' was a son of the Westmoreland bull and one of these heifers, who came to be celebrated in agricultural history as 'Old Comely', for she was slaughtered at the age of twenty-six. He bred his cattle so that they produced an enormous amount of fat, as hitherto there had been a difficulty in producing animals to fatten readily; but this he pushed to too great an extreme, so that there has been a reaction. The following is a description of a six-year-old bull, got by 'Twopenny' out of a Canley cow: ' His head, chest, and neck remarkably fine and clean; his chest extraordinarily deep; his brisket bearing down to his knees; his chine thin, loin narrow at the chine, but remarkably wide at the hips. Quarters long, round bones snug, but thighs rather full and remarkably let down. The carcase throughout, chine excepted, large, roomy, deep, and well spread.' 2 The new longhorn, however good for the grazier, was not a good nilker. Bakewell was a great believer in straw as

1 Culley on Live Stock (1807), p. 56.

2 Marshall, Rural Economy of the Midland Counties, i. 273. 
a food, and strongly objected to having it trodden into manure ; his beasts were largely fed on it, in such small quantities that they greedily ate what was before them and wasted little. His activity was not confined to the breeding of cattle and sheep, for he also produced a breed of black horses, thick and short in the body, with very short legs and very powerful, two ploughing 4 acres a day, a statement which seems much exaggerated; and was famous for his skill in irrigating meadows, by which he could cut grass four times a year. $\mathrm{He}$ was a firm believer in the wisdom of treating stock gently and kindly, and his sheep were kept as clean as racehorses. A visitor to Dishley saw a bull of huge proportions, with enormous horns, led about by a boy of seven. He travelled much, and admired the farms of Norfolk most in England, and those of Holland and Flanders abroad, founding his own system on these. It was his opinion that the Devon breed of cattle were incapable of improvement by a cross of any other breed, and that from the West Highland heifer the best breed of cattle might be produced.

He died in 1795 , and apparently did not keep what he made, owing largely to his boundless hospitality, which had entertained Russian princes, German royal dukes, English peers, and travellers from all countries. His breed of cattle has completely disappeared, unless traces survive in the lately resuscitated longhorn breed, but his principles are still acted upon, viz. the correlation of form, and the practice of consanguineous breeding under certain conditions.

Bakewell's earliest pupil was George Culley, who devoted himself to improving the breed of cattle, and became one of the most famous agriculturists at the end of the eighteenth and the commencement of the nineteenth centuries. Another farmer to whom English agriculture owes much was John Ellman of Glynde, born in I753, who by careful selection firmly established the reputation of the Southdown sheep which had previously been hardly recognized. $\mathrm{He}$ was one of the 
founders of the Smithfield Cattle Show in I793, which helped materially to improve the live stock of the country.

The relations between landlord and tenant, judging from the accounts of contemporary writers, were generally good. Leases were less frequent than agreements voidable by six months' notice on either side, and when there was a tenancy-atwill the tenant who entered as a young man was often expected to hand on the holding to his posterity, and therefore executed improvements at his own cost, so complete was the trust between landlord and tenant. Tenants then did much that they would refuse to do to-day, as the following lease, common in the Midlands in 1786 , shows ${ }^{1}$ :

Tenant agrees to take, \&c., and to pay the stipulated rent within forty days, without any deduction for taxes, and double rent so long as he continues to hold after notice given.

To repair buildings, accidents by fire excepted.

To repair gates and fences.

When required, to cut and plash the hedges, and make the ditches 3 feet by 2 feet, or pay or cause to be paid to the landlord Is. per rood for such as shall not be done after three months' notice has been given in writing.

Not to break up certain lands specified in the schedule, "under $£ 20$ an acre.'

Not to plough more than a specified number of acres of the rest of the land in any one year, under the same penalty.

To forfeit the same sum for every acre that shall be ploughed for any longer time than three crops successively, without making a clean summer fallow thereof after the third crop.

And the like sum for every acre over and above a specified number (clover excepted) that shall be mown in any one year.

At the time of laying down arable lands to grass he shall manure them with 8 quarters of lime per acre, and sow the same with $12 \mathrm{lb}$. of clover seeds, and one bushel of ryegrass per acre.

${ }^{1}$ Victoria County History: Warwickshire, Agriculture. 
Shall spend on the premises all hay, straw, and manure, or leave them at the end of the term.

Tenant on quitting to be allowed for hay left on the premises, for clover and ryegrass sown in the last year, and for all fallows made within that time.'

A striking picture of the conditions prevailing in many parts of England at this period is given by Mr. Loch in his account of the estates of the Marquis of Stafford. ${ }^{2}$ When this nobleman inherited his property in Staffordshire and Shropshire, much of the land, as in other parts of England, was held on leases for three lives, a system said to have been ruinous in its effects. Although the farms were held at one-third of their value, nothing could be worse than the course of cultivation pursued, no improvements were carried out, and all that could be hoped for was that the land would not be entirely run out when the lease expired. The closes were extremely small and of the most irregular shape; the straggling fences occupied a large portion of the land; the crookedness of the ditches, by keeping the water stagnant, added to, rather than relieved, the wetness of the soil. Farms were much scattered, and to enable the occupiers to get at their land, lanes wound backwards and forwards from field to field, covering a large quantity of ground.

It is to the great credit of the Marquis of Stafford that this miserable state of things was swept away. Lands were laid together, the size of the fields enlarged, hedges and ditches straightened, the drainage conducted according to a uniform plan, new and substantial buildings erected, indeed the whole countryside transformed.

Another evil custom on the estate had been to permit huts

1 In Lancashire at this date it was not uncommon, when a tenant wished for his farm or a particular field to be improved by draining, marling, liming, or laying down to grass, to hand it over to the landlord for the process; who, when completed, returned it to the tenant with an advanced rent of Io per cent. upon the improvements.-Marshall, Review of Reports to Board of Agriculture (under Lancashire).

${ }^{2} 1820$, p. 173 et seq. 
of miserable construction to be erected to the number of several hundreds by the poorest, and in many instances the most profligate, of the population. They were not regularly entered in the rental account, but had a nominal payment fixed upon them which was paid annually at the court leet. These cottages were built on the sides of the roads and on the lord's waste, which was gradually absorbed by the encroachment, which the occupiers of these huts made from time to time by enclosing the land that lay next them. These wretched holdings gradually fell into the hands of a body of middlemen, who underlet them at an extravagant rent to the occupiers; and these men began to consider that they had an interest independent of the landlord, and had at times actually mortgaged, sold, and devised it. This abuse was also put an end to, the cottagers being made immediate tenants of the landlord, to their great gain, but to this day small aggregations of houses in Shropshire called 'Heaths' mark the encroachments of these squatters on the roadside wastes. This class, indeed, has been well known in England since the Middle Ages. Norden speaks of them in 1602 , and so do many subsequent writers. Numbers of small holdings exist to-day obtained in this manner, and the custom must to some extent have counteracted the effect of enclosure. ${ }^{1}$

The roads of England up to the end of the eighteenth century were generally in a disgraceful condition. Some improvement was effected in the latter half of the century, but it was not until the days of Telford and Macadam that they assumed the appearance with which we are familiar; and long after that, though the main roads were excellent, the by-roads were often atrocious, as readers of such books as Handley Cross, written in the middle of the nineteenth century, will remember.

Defoe in his tour in 1724 found the road between S. Albans

1 See Hasbach, op. cit. pp. 77 sq.; Annals of Agriculture, xxxvi. 497 ; Scrutton, Commons and Common Fields, p. 139. 
and Nottingham 'perfectly frightful,' and the great number of horses killed by the 'labour of these heavy ways a great charge to the country'. He notes, however, an improvement from turnpikes. Many of the roads were much worn by the continual passing of droves of heavy cattle on their way to London. Sheep could not travel in the winter to London as the roads were too heavy, so that the price of mutton at that season in town was high. Breeders were often compelled to sell them cheap before they got to London, because the roads became impassable for their flocks when the bad weather set in. ${ }^{1}$

In 1734 Lord Cathcart wrote in his diary: 'All went well until I arrived within 3 miles of Doncaster, when suddenly my horse fell with a crash and with me under him. I fancied myself crushed to death. I slept at Doncaster and had a bad night. I was so bad all day, that I could get no further than Wetherby. Next day I was all right again. I had another terrible fall between North Allerton and Darlington, but was not a bit the worse.' 2

It was owing to this defective condition of the roads that the prices of corn still differed greatly in various localities; there would be a glut in one place and a deficiency in another, with no means of equalizing matters. To the same cause must be attributed in great measure the slow progress made in the improvement of agriculture. New discoveries travelled very slowly; the expense of procuring manure beyond that produced on the farm was prohibitive; and the uncertain returns which arose from such confined markets caused the farmer to lack both spirit and ability to exert himself in the cultivation of his land. ${ }^{3}$ Therefore farming was limited to procuring the subsistence of particular farms rather than feeding the public. The opposition to better roads was due in great measure to the landowners, who feared that if the markets in their neighbourhood were rendered accessible to

${ }^{1}$ Defoe, Tour, ii. I, 178 et seq. ${ }^{2}$ R.A.S. E. Journal (3rd Ser.), ii. 9.

3 Horner, Inquiry into the Means of Preserving the. Public Roads ( 1767$)$, pp. 4 et seq. 
distant farmers their estates would suffer. But they were not alone in their opposition; in the reign of Queen Anne the people of Northampton were against any improvement in the navigation of the Nene, because they feared that corn from Huntingdon and Cambridge would come up the river and spoil their market. ${ }^{I}$ Horner was very enthusiastic over the improvement recently effected: 'our very carriages travel with almost winged expedition between every town of consequence in the kingdom and the metropolis,' and inland navigation was soon likely to be established in every part, in consequence of which the demand for the produce of the land increased and the land itself became more valuable and rents rose. 'There never was a more astonishing revolution accomplished in the internal system of any country'; and the carriage of grain was effected with half the former number of horses.

It is clear, however, that he was easily satisfied, and this opinion must be compared with the statements of Young and Marshall, who were continually travelling all over England some time after it was written; and found the roads, in many parts, in a very bad state.

Even near London they were often terrible. 'Of all the cursed roads that ever disgraced this kingdom in the very ages of barbarism, none ever equalled that from Billericay to the King's Head at Tilbury. ${ }^{2}$ It is for near 12 miles so narrow that a mouse cannot pass by any carriage. I saw a fellow creep under his wagon to assist me to lift, if possible, my chaise over a hedge. The ruts are of an incredible depth, and everywhere chalk wagons were stuck fast till 20 or 30 horses tacked to each drew them out one by one.' Others said that turnpike roads were the enemies of cheapness; as soon as they opened up secluded spots, low prices vanished and all tended to one level. Owing to the work of Telford and Macadam, the high roads by the first quarter of the nineteenth

1 Victoria County History: Northants., ii. 2 co.

2 Young, Southern Tour (ed. 2), p. 88. 
century attained a high pitch of excellence ; and were thronged with traffic, coaches, postchaises, private carriages, equestrians, carts and wagons: so animated a sight that our forefathers built small houses called 'gazebos' on the sides of the road, where they met to take tea and watch the ever varying stream. . It should not be forgotten, too, that the inns, where numbers of horses put up, were splendid markets for the farmers' oats, hay, and straw.

The seasons in the latter part of the eighteenth century were distinguished for being frequently bad. In I774 Gilbert White wrote, "Such a run of wet seasons as we have had the last ten or eleven years would have produced a famine a century or two ago.' Owing to the dearness of bread in 1767 riots broke out in many places, many lives were lost, and the gaols were filled with prisoners. ${ }^{1}$ I 779 was, however, a year of great fertility and prices were low all round: wheat $33^{s .} 8 \mathrm{~d}$., barley $26 s$., oats $13 s$. $6 d$., wool $12 s$. a tod of $28 \mathrm{lb}$.: and there were many complaints of ruined farmers and distressed landlords. Though England was now becoming an importing country, the amount of corn imported was insufficient to have any appreciable effect on prices, which were mainly influenced by the seasons, as the following instance of the fluctuations caused by a single bad season ( 1782 ) testifies ${ }^{2}$ :

Prices after harvest of $178 \mathrm{I}$.

Wheat, per bushel . $L_{5} s_{0} d$.

Barley ", 29

Dutch oats for seed 1 I 8

Clover seed, per cwt. I I I 6
Prices after harvest of 1782 .

Wheat, per bushel . $\begin{array}{ccc}s . & d . \\ \text { ro } & 6\end{array}$

Barley ", 972

Dutch oats for seed 36

Clover seed, per cwt. 5 ro 0

1 Tooke, History of Prices, i. 68. It is difficult to understand the price of the quartern loaf, Is. $6 d$. in 1766 , as wheat was only $43 s$. Id. a quarter. Prices of wheat in these years were:

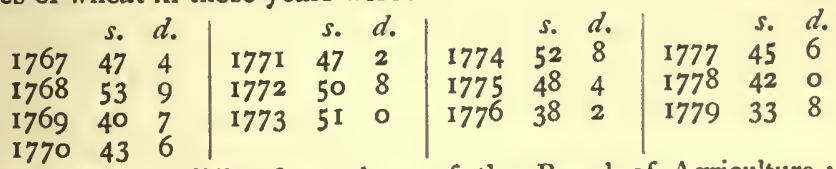

These returns differ from those of the Board of Agriculture; see Appendix III.

2 Annals of Agriculture, iii. 366. 
The summer of 1783 was amazing and portentous and full of horrible phenomena, according to White, with a peculiar haze or smoky fog prevailing for many weeks. 'The sun at noon looked as blank as a clouded moon, and shed a rustcoloured ferruginous light on the ground and floors of rooms.' This was succeeded by a very severe winter, the thermometer on December Io being $I^{\circ}$ below zero; the worst since I 739-40.

In 1788 occurred a severe drought in the summer, 5,000 horned cattle perishing for lack of water. ${ }^{1}$ In I79I there was a remarkable change of temperature in the middle of June, the thermometer in a few days falling from $75^{\circ}$ to $25^{\circ}$, and the hills of Kent and Surrey were covered with snow.

We have now to deal with one of those landowners whose great example is one of the glories of English agriculture. Coke of Holkham began his great agricultural work about 1776 on an estate where, as old Lady Townshend said, 'all you will see will be one blade of grass and two rabbits fighting for that;' in fact it was little better than a rabbit warren. It has been said that all the wheat consumed in the county of Norfolk was at this time imported from abroad; but this is in direct contradiction to Young's assertion, already noted, that there were in 1767 great quantities of wheat besides other crops in the county. Coke's estate indeed seems to have been considerably behind many parts of the shire when he began his farming career. ${ }^{2}$ When Coke came into his estate, in five leases which were about to expire the farms were held at $35.6 \mathrm{~d}$. an acre; and in the previous leases they had been Is. $6 d$. an acre. We may judge of the quality of this land by comparing it with the average rent of Ios. which Young says prevailed at this time. With a view to remedy this state of things he studied the agriculture of other counties, and his observations thereon reveal a very poor kind of farming in many places : in Cheshire

1 Baker, Seasons and Prices, pp, 224 et seq.

2 A. Stirling, Coke of Holkham, i. 249. 
the rich pasture was wasted and the poor impoverished by sheer ignorance, in Yorkshire luxuriant grass was understocked, in Shropshire there were hardly any sheep; in his own part of Norfolk the usual rotation was three white straw crops and then broadcast turnips. ${ }^{1}$ This Coke changed to two white crops and two years pasture, and he dug up and brought to the surface the rich marl which lay under the flint and sand, so that clover and grasses began to grow. So successful was he in this that in 1796 he cut nearly 400 tons of sainfoin from ro4 acres of land previously valued at I2s. an acre. He increased his flock of sheep from 800 worthless animals with backs as narrow as rabbits, the description of the Norfolk sheep of the day, to 2,500 good Southdowns. Encouraged by the Duke of Bedford, another great agriculturist, he started a herd of North Devons, and, fattening two Devons against one Shorthorn, found the former weighed I 40 stone, the latter I Io, and the Shorthorn had eaten more food than the two Devons. However, a single experiment of this kind is not very conclusive.

The ploughs of Norfolk were, as in many other counties, absurdly over-horsed, from three to five being used when only two were necessary; so Coke set the example of using two whenever possible, and won a bet with Sir John Sebright by ploughing an acre of stiff land in Hertfordshire in a day with a pair of horses. He transformed the bleak bare countryside by planting 50 acres of trees every year until he had 3, coo acres well covered, and in 18,32 had probably the unique experience of embarking in a ship which was built of oak

1 But in other parts of it the cultivation of turnips was well understood, for the Complete Farmer, s.v. Turnips (ed. 3), says that about 1750 Norfolk farmers boasted that turnips had doubled the value of their holdings, and Norfolk men were famous for understanding hoeing and, thinning, which were little practised elsewhere. Further, Young, S.outhern Tour, p. 273, says: 'the extensive use of turnips is known but little of except in Norfolk, Suffolk, and Essex. I found no farmers but in these counties that understood anything of fatting cattle with them; feeding lean sheep being the only use they put them to.' 
grown from the acorns he had himself planted. ${ }^{1}$ Between I 776 and 1842 (the date of his death) he is said to have spent $£_{536,992}$ on improving his estate, without reckoning the large sums spent on his house and demesne, the home farm, and his marsh farm of 459 acres. This expenditure paid in the long run, but when he entered upon it, it must have seemed very doubtful if this would be the case. A good understanding between landlord and tenant was the basis of his policy, and to further this he let his farms on long leases, at moderate rents, with few restrictions. When farmers improved their holdings on his estate the rent was not raised on them, so that the estate benefited greatly, and good tenants were often rewarded by having excellent houses built for them; so good, indeed, that his political opponents the Tories, whom he, as a staunch Whig detested, made it one of their complaints against him that he built palaces for farm-houses. At first he met with that stolid opposition to progress which seems the particular characteristic of the farmer. For sixteen years no one followed him in the use of the drill, though it was no new thing; and when it was adopted he reckoned its use spread at the rate of a mile a year. Yet eventually he had his reward; his estate came to command the pick of English tenant farmers, who never left it except through old age, and would never live under any other landlord. Even the Radical Cobbett, to whom, as to most of his party, landlords were, and are, the objects of inveterate hatred, said that every one who knew him spoke of him with affection. Coke was the first to distinguish between the adaptability of the different kinds of grass seeds to different soils, and thereby made the hitherto barren lands of his estate better pasture land than that of many rich counties. Carelessness about the quality of grasses sown was universal for a long time. The farmer took his seeds from his own foul hayrick, or sent to his neighbour for a supply of rubbish; even Bakewell derived his stock

${ }^{1}$ A. Stirling, op. cit. i. 264. 
from his hayloft. It was not until the Suciety for the Encouragement of Arts offered prizes for clean hay seeds that some improvement was noticeable. In Norfolk, as in other parts of England, there was at this time a strong prejudice against potatoes; the villagers of Holkham refused to have anything to do with them, but Coke's invincible persistency overcame this unreasoning dislike and soon they refused to do without them.

Coke was a great advocate for sowing wheat early and very thick in the rows, and for cutting it when ear and stem were green and the grain soft, declaring that by so doing he got 2s. a quarter more for it; he also believed in the early cutting of oats and peas. It was his custom to drill 4 bushels of wheat per acre, which he said prevented tillering and mildew. He was the first to grow swedes on a large scale. 'The famous Holkham Sheep-shearings, known locally as 'Coke's Clippings', which began in 1778 and lasted till $182 \mathrm{I}$, arose from his practice of gathering farmers together for consultation on matters agricultural, and developed into worldfamous meetings attended by all nationalities and all ranks, men journeying from America especially to attend them, and Lafayette expressed it as one of his great regrets that he had never attended one. At these gatherings all were equal, the suggestion of the smallest tenant farmer was listened to with respect, and the same courtesy and hospitality were shown to all whether prince or farmer. At the last meeting in $182 \mathrm{I}$ no less than 7,000 people were present. His skill, energy, and perseverance worked a revolution in the crops; his own wheat crops were from ro to 12 coombs an acre, his barley sometimes nearly 20. The annual income of timber and underwood was $£ 2,700$, and from 1776 to 1816 he increased the rent roll of his estate from $£ 2,200$ to $£ 20,000$, which, even after allowing for the great advance in prices during that period, is a wonderful rise. It is a very significant fact that there was not an alehouse on

$$
1 \text { R. A. S. E. Journal (1895), p. } 12 .
$$


the estate, and in connexion with this, and with the fact that his improvements made a constant demand for labour, we are not surprised to learn that the workhouse was pulled down as useless, for it was always empty, and this at a time when the working-classes of England were pauperized to an alarming degree. The year 1818 was one of terrible distress all over England in country and town, yet at his sheep-shearing of that year Coke was. enabled to say he had trebled the population of his estate and not a single person was out of employment, though everywhere else farmers were turning off hands and cutting down wages. Principally through his agency, between 1804 and $182 \mathrm{I}$, no less than I53 enclosures took place in Norfolk, while between I790 and $1810,2,000,000$ acres of waste land in England were brought under cultivation largely by his efforts. He is said, indeed, to have transformed agriculture throughout England, and, but for that, the country would not have been able to grow enough food for its support during the war with Napoleon, and must have succumbed. 


\section{CHAPTER XVII}

$$
\text { I793-18I5 }
$$

THE GREAT FRENCH WAR.-THE BOARD OF AGRICULTURE.-HIGH PRICES, AND HEAVY TAXATION

THIS period, that of the great war with France, was one generally of high prices and prosperity for landowners and farmers. It was a prosperity, however, that was largely fictitious, and when the high prices of the war time were over, it was succeeded by many disastrous years. The prosperity, too, was also largely neutralized by a crushing weight of taxation and rates, while the labourer, although his wages were increased, found prices grow at a much greater rate, and it was, as Thorold Rogers has said, the most miserable period in his history.

Its commencement was marked by the foundation of the Board of Agriculture. On May I5, I793, Sir John Sinclair ${ }^{1}$ moved in the House of Commons, "that His Majesty would take into his consideration the advantages which might be derived from the establishment of such a board, for though in some particular districts improved methods of cultivating the soil were practised, yet in the greatest part of these kingdoms the principles of agriculture are not sufficiently understood, nor are the implements of husbandry or the stock of the farmer brought to that perfection of which they are capable." His Majesty's faithful Commons were persuaded that if it were founded a spirit of improvement might be encouraged, which would result in important national benefits.

The motion was carried by IOI to 26. By its charter the board consisted of a president, 16 ex-officio and 30 ordinary 
members, with honorary and corresponding members. It was not a Government department in the modern sense of the term, but a society for the encouragement of agriculture, as the Royal Society is for the encouragement of science. It was, indeed, supported by parliamentary grants, receiving a sum of $£_{3,000}$ a year, but the Government had only a limited control over its affairs through the ex-officio members, among whom were the Archbishops of Canterbury and York, the Lord Chancellor, the First Lord of the Admiralty, and the Speaker.

The first president was Sir John Sinclair, and the first secretary Arthur Young, with a salary of $£_{400}$ a year, which he thought insufficient. ${ }^{1}$ The first task of the new board was that of preparing statistical accounts of English agriculture, and it was intended to take in hand the commutation of tithes, which would have been a great boon to farmers, with whom the prevailing system of collecting tithes was very unpopular; but the Primate's opposition stopped this. The board appointed lecturers, procured a reward for Elkington for his draining system, encouraged Macadam in his plans for impioving roads, and Meikle the inventor of the thrashing machine, and obtained the removal of taxes on draining tiles, and other taxes injurious to agriculture. It also recommended the allotment system, and Sinclair desired 3 acres and a cow for every industrious cottager. During the abnormally high prices of provisions from I794-6, the quartern loaf in London in 1795 being $I s .6 d$., though next year it dropped to $7 \frac{3}{4} d .{ }^{2}$ the board made experiments in making bread with substitutes for wheat, which resulted in a public exhibition of eighty different sorts of bread. Its efforts were generally followed by increased zeal among agriculturists; but Sinclair, an able but impetuous man, ${ }^{3}$ appears to have taken things too much into his own hands and pushed them too speedily.

1 Autobiography, p. 242.

2 Eden, State of the Poor, i. 18.

3 'Had his industry been under the direction of a better judgement, he would have been an admirable president.'-Young, Autobiography, p. 316. 
Financial difficulties came, chiefly owing to the cost of the surveys, which had been hurried on with undue haste and often with great carelessness, the surveyors sometimes being men who knew nothing of the subject.

Sinclair was deposed from the presidency in 1798, and succeeded by Lord Somerville. He again was succeeded by Lord Carrington, under whose presidency the board offered premiums (the first of $£ 200$ ), owing to the high price of wheat and consequent distress, for essays on the best means of converting certain portions of grass land into tillage without exhausting the soil, and of returning the same to grass, after a certain period, in an improved state, or at least without injury. The general report, based on the information derived from these essays, states that no high price of corn or temporary distress would justify the ploughing up of old meadows or rich pastures, and that on certain soils well adapted to grass age improves the quality of the pasture to a degree which no system of management on lands broken up and laid down can equal. In spite of this, the cupidity of landowners and farmers, when wheat was a guinea a bushel or at prices near it, led to the ploughing up of much splendid grass land, which was never laid down again until, perhaps in recent years, owing to the low price of grain; so that some of the land at all events has, owing to bad times, returned to the state best suited to it.

The board looked upon the enclosure and cultivation of waste lands, which in England they estimated at 6,000,000 acres, ${ }^{1}$ as a panacea for the prevailing distress, and after much opposition they managed to pass through both Houses in 1801 a Bill cheapening and facilitating the process of parliamentary enclosure. This Act, 4I Geo. III, c. Iog, 'extracted a number of clauses from various private Acts and enacted that they should hold good in all cases where

I The Report of the Committee on Waste Lands, 1795, estimated wastes and commons at $7,800,000$ acres, p. 221 . 
the special Act did not expressly provide to the contrary.' Another benefit rendered to agriculture was the establishment in 1803 of lectures on agricultural chemistry, the first lecturer engaged being Mr., afterwards Sir Humphry, Davy, who may be regarded as the father of agricultural chemistry.

In I806 Sinclair was re-elected president, and his second term was mainly devoted to completing the agricultural surveys of the different counties, which, before his retirement in I813, he had with one or two exceptions the satisfaction of seeing finished. Though over-impetuous, he rendered valuable service to agriculture, not only by his own energy but by stirring up energy in others; as William Wilberforce the philanthrophist said, 'I have myself seen collected in that small room several of the noblemen and gentlemen of the greatest properties in the British Isles, all of them catching and cultivating an agricultural spirit, and going forth to spend in the employment of labourers, and I hope in the improvement of land, immense sums which might otherwise have been lavished on hounds and horses, or squandered on theatricals.'

Among the numerous subjects into which the board inquired was the divining rod for finding water, which was tested in Hyde Park in I8or, and successfully stood the test. In 1805 , Davy the chemist reported on a substance in South America called 'guana', which he had analysed and found to contain one-third of ammoniacal salt with other salts and carbon, but its use was not to come for another generation. From the time of Sinclair's retirement in $\mathrm{I}_{8} \mathrm{I} 3$ the board declined. Arthur Young, its secretary, had become blind and his capacity therefore impaired. One year its lack of energy was shown by the return of $£ 2,000$ of the Government grant to the Treasury because it had nothing to spend it on. The Prime Minister, Lord Liverpool, was against it, the clergy feared the commutation of tithe which the board 
advocated, the legal profession was against the Enclosure Act, the landed interest thought the surveys were intended for purposes of taxation; and the grant being withdrawn, an effort to maintain the board by voluntary subscription failed, so that it dissolved in 1822 , after doing much valuable work for English agriculture.

Before its extinction it had held in I82I, at Aldridge's Repository, the first national agricultural show. $£ 685$ was given in prizes, and the entries included ro bulls, 9 cows and heifers, several fat steers and cows, 7 pens of Leicester and Cotswold rams and ewes; I 2 pens of Down, and 9 or 10 pens of Merino rams and ewes. ${ }^{1}$ Most of the cattle shown were Shorthorn, or Durham, as they were then called, with some Herefords, Devons, Longhorns, and Alderneys. There were also exhibits of grass, turnip-seed, roots, and implements.

This first national show had been preceded by many local ones. $^{2}$ The end of the eighteenth and beginning of the nineteenth centuries saw the establishment all over England of farmers' clubs, cattle shows, and ploughing matches.

The period now before us is marked by the great work of the Collings, who next to Bakewell did most to improve the cattle of the United Kingdom. Charles Colling was born in 175I, and the scene of his famous labours was Ketton near Darlington. He had learnt from Bakewell the all-importance of quality in cattle, and determined to improve the local Shorthorn breed near his own home, which had been described in I 744 as ' the most profitable beasts for the dairyman, butcher, and grazier, with their wide bags, short horns, and large bodies.' He was to make these 'profitable beasts' the best

1 The Merino was largely imported into England by the efforts of George III, and a Merino Society was formed in I8II; but many circumstances made it of such little profit to cultivate it in preference to native breeds, that it was diverted to Australia.-Burnley, History of Wool, p. 17.

2 The first, the Bath and West of England, was established in 1777. 
all-round cattle in the world, and to succeed where George Culley had failed. The first bull of merit he possessed was 'Hubback ${ }^{1}$ ', described as a little yellow, red, and white fiveyear-old, which was mated with cows afterwards to be famous, named Duchess, Daisy, Cherry, and Lady Maynard. At first Colling was against in-breeding, and not until I793 did he adopt it, more by accident than intention, but the experiment being successful he became an enthusiast. The experiment was the putting of Phœnix to Lord Bolingbroke, who was both her half-brother and her nephew, and the result was the famous Favourite. A young farmer who saw Favourite and his sister at Darlington in I799, was so struck by them that he paid Colling the first 100 guineas ever given for a Shorthorn cow. ${ }^{2}$

One of Hubback's daughters had in 1795, by Favourite, a roan calf which grew to be the celebrated Durham $\mathrm{Ox}$, which at five and a half years weighed 3,024 lb, and was sold for $£$ r 40 . It was sold again for $£ 250$, the second purchaser refusing $£ 2,000$ for it, and taking it round England on show made a profitable business out of it, in one day in London making $£ 97$. A still more famous animal was the bull Comet, born 1804 , which at the great sale in 1810 fetched I,000 guineas. This bull was the crowning triumph of Colling's career and the result of very close breeding, being described as the best bull ever seen, with a fine masculine head, broad and deep chest, shoulders well laid back, loins good, hind-quarters long, straight and well packed, thighs thick, with nice straight hocks and hind legs. Perhaps Colling thought he had pursued in-and-in breeding too far, at all events in I8ro he dispersed his famous herd. The sale was

1 R. A. S. E. Journal, i 899, p. 7.

2 Higher prices had been realized for the improved Longhorns; in I791, at the sale of Mr. Fowler of Little Rollright, Sultan a two-year-old bull fetched 210 guineas, and a cow 260 guineas; and at Mr. Paget's sale in 1793, a bull of the same breed sold for 400 guineas. - Culley on Live Stock, p. 59 . 
held at a most propitious time, for the Durham Ox had advertised the name of Colling far and wide, and owing to the war prices were very high. Comet fetched 1,000 guineas, and the other forty-seven lots averaged $£$ I $5 \mathrm{I} 8 s .5 d$., an unheard-of sale, yet all the auctioneer got was 5 guineas, much of the work of the sale falling on the owner, and the former sold the stock with a sand-glass.

After the sale at Ketton, Brampton, the farm of Charles's brother Robert, became the centre of interest to the Shorthorn world. Robert obtained excellent prices for his stock, five daughters of his famous bull George fetching 200 guineas each. Probably he, like his brother, pursued in-and-in breeding too far, and in 1818 there was another great sale; but warprices had gone and agriculture was depressed, so that the cattle fetched less than at Ketton, but still averaged $£ 128$ I4s. 9d. for 6I lots, and 22 rams averaged $£_{39} 6$ s. $4 d$. Robert died in 1820 , his brother in $\mathrm{I}_{3}{ }_{3} 6$.

It cannot be said that the Collings were the founders of a new breed of cattle; they were the collectors and preservers of an ancient breed that might otherwise have disappeared. ${ }^{1}$ The object of good breeders was now to get their cattle fat at an early age, and they so far succeeded as to sell three-yearold steers for $£_{20}$ apiece, generally fed thus: in the first winter, hay and turnips; the following summer, coarse pasture; the second winter, straw in the foldyard and a few turnips; next summer, tolerable good pasture; and the third winter, as many turnips as they could eat. ${ }^{2}$

Cattle at this time were classified thus: Shorthorns, Devons, Sussex, Herefords (the two latter said by Culley to be varieties of the Devon), Longhorned, Galloway or Polled, Suffolk Duns, Kyloes, and Alderneys.

Sheep thus: the Dishley Breed (New Leicesters), Lincolns, Teeswaters, Devonshire Notts, Exmoor, Dorsetshire, Here-

1 R. A.S. E. Journal, 1899, p. 28.

${ }^{2}$ Culley on Live Stock (1807), pp. 46-7. 
fordshire, Southdown, Norfolk, Heath; Herdwick, Cheviot, Dunfaced, Shetland, Irish. ${ }^{1}$

With the increased demand for corn and meat from the towns the necessity of new and better implements became apparent, and many patents were taken out : by Praed, for drill ploughs, in 1781 ; by Horn, for sowing machines, in 1784 ; by Heaton, for harrows, in 1787 ; for sowing machines, by Sandilands, I788; for reaping machines, by Boyce, I 799 ; winnowing machines, by Cooch, I800; haymakers, by Salmon, I8I6 ; and for scarifiers, chaff-cutters, turnip-slicers, and food-crushers. ${ }^{2}$ But the great innovation was the threshing machine of Meikle. Like most inventions, it had forerunners. The first threshing machine is mentioned in the Select Transactions of the. Society of Improvers in the Knozuledge of Agriculture in Scotland, published in 1743 by Maxwell. It was invented by Michael Menzies, and by it one man could do the work of six. One machine was worked by a great water-wheel and triddles, another by a little wheel of 3 feet diameter, moved by a small quantity of water. The first attempts to substitute horse or other power for manual in threshing were directed to the revolution of jointed flails, which should strike the floor on which the corn was spread, but this proved unsatisfactory, so that rubbing the grain out of the straw by revolving cylinders was tried. ${ }^{3}$ Young, in his northern tour, met a Mr. Clarke at Belford in Northumberland, who was famous for mechanics, ${ }^{4}$ among his inventions being a threshing machine worked by one horse, which does not seem to have effected much. Eventually Mr. A. Meikle, of Houston Mill near Haddington, in 1798 erected a machine the principles of which, much modified, are those of to-day; and in 1803

1 Culley on Live Stock, p. vi.

${ }^{2}$ R.A.S.E.Journal, 1892, p. 27.

3 Morton, Cyclopaedia of Agriculture, ii. 964.

4 Northern Tour, iii. 49. Clarke also experimented on the effect of electricity on vegetables, electrifying turnips in boxes with the result that growth was quickened and weight increased. 
Mr. Aitchison, of Drumore in East Lothian, first applied steam to threshing. It was some time, however, before this beneficent invention was generally used, and when the machines were used they were usually driven by horse- or water-power until about 1850 . In 1883 Messrs. Howard, of Bedford, adapted a sheaf-binding apparatus to the threshing machine. With new implements came new crops; the Swede turnip was grown on some farms in Notts. just before I800, but it is not known who introduced it. ${ }^{2}$ The mangel wurzel was introduced about $\mathrm{I} 780-5$ by Parkyns, and prickly comfrey in $18 \mathrm{II}$.

The year I 795 was one of great scarcity owing to the wet and stormy summer, and in August wheat went up to ro8s. a quarter. ${ }^{2}$ As usual many other causes but the right one were put forth, and the old accusations of monopoly, forestalling, and regrating were heard again. The war with France, with more reason, was considered to have helped in raising prices, but the chief cause was the bad season. The members of both Houses of Parliament bound themselves to reduce the consumption of bread in their homes by one-third, and recommended others to a similar reduction. It was a period of terrible distress for the agricultural labourer. His wages were about $9 s$. a week, and it was impossible for him to live on them, so that what is known as 'the allowance system' came in. At Speenhamland in Berkshire, in this year, the magistrates agreed that it was not expedient to help the labourer by regulating his wages according to the statute of Elizabeth, but recommended the farmers to increase their pay in proportion to the present price of provisions, and they also granted relief to all poor and industrious men according to the price of bread. They were merely giving effect to Gilbert's Act of 1782 , which legalized the supplementing of the wages of able-bodied men from the rates, and the decision

2 Tooke, History of Prices, i. 182. 
was nicknamed the 'Speenhamland Act' because it was so generally followed. However well meant, the effect was most demoralizing and the English labourer, already too prone to look to the State for help, was induced to depend less on his own exertions. The real remedy would have been a substantial increase of his scanty wages. As it was, landowner and farmer were often paying the labourer in rates money that would far better have come to him in wages, and the rates in some districts became so burdensome that land was thrown out of cultivation. In the same year as the Speenhamland Act the statute 36 Geo. III, c. 23 , forbade the removal of persons from any parish until they were in actual need of support; but although the law was thus relaxed, the fixed principle which caused the refusal of all permanent relief to labourers who had no settlement in the parish acted as a very efficient check on migration, though, as we have seen, it did not entirely check it. In 1796 the question of regulating the labourers' wages by Parliament was raised; but Pitt, remembering such schemes had always failed, was hostile, and the matter dropped. " In the same year Eden made his inquiries concerning the rate of wages and the cost of living. In Bedford, he found the agricultural labourer was getting $I s .2 d$. a day and beer, with extras in harvest ${ }^{2}$; but bacon was Iod. a lb. and wheat I2s. a bushel. However, parish allowances were liberal, a man, his wife, and four children sometimes receiving I Is. a week from that source.

In Cumberland the labourer was being paid $10 d$. to Is. a day with food, or Is: $6 d$. to Is. $8 d$. without; in Hertfordshire, Is. $6 d$. a day; in Suffolk, is. $4 d$. a day and beer.

Nearly everywhere his expenditure was much in excess of

1 Autobiography of A. Young, p. 256.

2 State of the Poor, i. 565 et seq.; Thorold Rogers, Work and Wages, p. 487. It is difficult to calculate the exact income of the labourer; besides extras in harvest, and relief from the parish, he might have a small holding, or common rights, also payments in kind and the earnings of his wife and children. 
his earnings, the yearly budgets of fifty-three families in twelve different counties showed generally large annual deficiencies, amounting in one case to $£ 2 \mathrm{I} \mathrm{r} 8 s .4 d$. In one case in Lindsey, where the deficiency was small, the family lived on bread alone. The factory system, too, had already deprived the labourer of many of his by-industries, and thus helped the pauperism for which landlord and farmer had to pay in rates.

About I788 Sir William Young proposed to send the unemployed labourers round to the parishioners to get work, their wages being paid by their employers and by the parish. This method of obtaining work was known as the 'roundsman system '!

Landlords, however, and farmers were profiting greatly by the high prices, which fortunately received a check by the abundant harvest of 1796 , which, with large imports, ${ }^{2}$ caused the price of wheat to fall to $57 s .3 d$., and in 1798 to $47 \mathrm{~s}$. Iod. It is difficult to conceive what instability, speculation, and disaster such fluctuations must have led to. In 1797 the Bank Restriction Act was passed, suspending cash payments, and thereby causing a huge growth in credit transactions, a great factor in the inflated prosperity of this period. In January, 1799, wool was 2s. a lb., and prices at Smithfield:

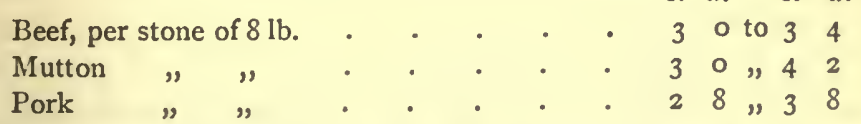

The summer of that year was uninterruptedly wet; some corn in the north was uncut in November, so that wheat went up to $94 s .2 d$., and in June, I800, was $134 s .5 d$., the scarcity being aggravated by the Russian Government laying an embargo on British shipping. ${ }^{3} \quad$ Yet Pitt denied that the high

${ }^{1}$ Hasbach, op. cit. p. 181 ; Eden, op. cit. ii. 27.

2 Imports of wheat and flour in 1796 were 879,200 quarters.

3 Yet imports were comparatively large : 1,264,520 quarters of wheat, against 463,185 quarters in 1799 . 
prices were due to the war. ${ }^{1}$ They were due, indeed, to several causes :

I. Frequent years of scarcity.

2. Increase of consumption, owing to the great growth of the manufacturing population, England during the war having almost a monopoly of the trade of Europe.

3. Napoleon's obstructions to importation.

4. The unprecedented fall of foreign exchanges.

5. The rise in the price of labour, scanty as it was.

6. Suspension of cash payments, which produced a medium of circulation of an unlimited nature, and led to speculation. ${ }^{2}$

In March, I80I, wheat was I56s.; beef at Smithfield, 5 s. to $6 s$. $6 d$. a stone; and mutton, $6 s .6 d$. to $8 s$. A rise in wages was allowed on all sides to be imperative, but the labourer even now got on an average little more than 9 s. a week, ${ }^{3}$ a very inadequate pittance, though generally supplemented by the parish. Arthur Young ${ }^{4}$ tells of a person living near Bury in 1801 , who, before the era of high prices, earned 5s. a week, and with that could purchase:

A bushel of wheat.

$$
\text { , malt. }
$$

I lb. of butter.

I lb. of cheese.

A pennyworth of tobacco.

1 Tooke, History of Prices, p. 219.

2 Farmer's Magazine, 1817, p. 60.

3 Thorold Rogers, Work and Wages, c. 18.

4 Annals of Agriculture, xxxvii. 265. In 1805, in Herefordshire, the labourer was getting about $6 s$. $6 d$. a week. - See Duncumb, General Vieav of Agriculture of Herefordshire. Those who lived in the farm-house often fared best : in 1808 the diet of a Hampshire farm servant was, for breakfast, bacon, bread, and skim nilk ; for lunch, bread and cheese and small beer; for dinner, between 3 p.m. and 4 p.m., pickled pork or bacon with potatoes, cabbages, turnips, or greens, and broths of wheat-flour and garden stuff. Supper consisted of bread and cheese and a pint of ale. His bread was usually made of wheat, which, considering the price, is remarkable. On Sundays he had fresh meat. The farmers lived in many cases little better; a statement which must be compared with others ascribing great extravagance to them.-Vancouver, General Viezu of the Agriculture of Hants (1808), p. 383. 
But in 1801 the same articles cost him:

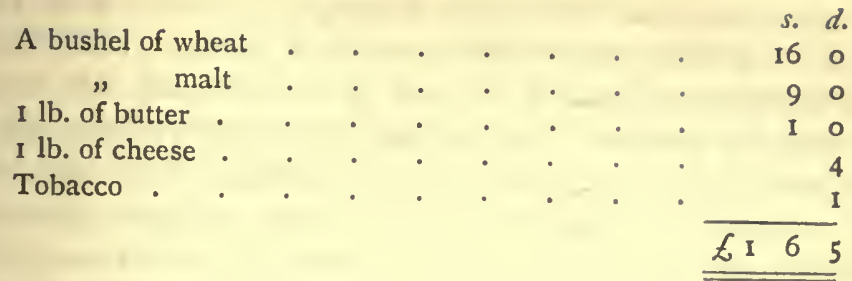

His wages were now $9 s$. , and his allowance from the rates $6 s$., so that there was a deficiency of in $s .5 d$.

The increase in the cost of living in the last thirty years is further illustrated by the following table:

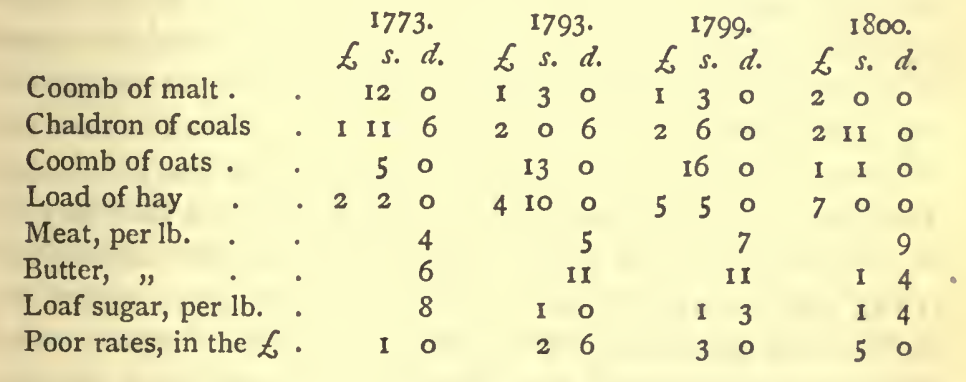

It was again proposed by Mr. Whitbread in the House of Commons that wages should be regulated by the price of provisions, and a minimum wage fixed; but there was enough sense in the House to reject this return to obsolete methods.

After March, I801, prices commenced to fall, owing to a favourable season and the reopening of the Baltic ports, which allowed imports to come in more freely, for most of our foreign corn at this time came from Germany and Denmark. At the end of the year wheat averaged 75s. $6 d$., and with fair seasons it came down in the beginning of 1804 to 498 . $6 d$. Beef at Smithfield was from $4 s$. to $5 s .4 d$. a stone, 
mutton from $4 s$. to $4 s$. $6 d^{\mathrm{I}}$ This great drop in prices was accompanied by an increase in wages, the labourer from 1804 to 1810 getting on an average $12 \mathrm{~s}$. a week; ${ }^{2}$ the cost of implements rose, so did the rate of interest, and the cry of agricultural distress in I804 was heard everywhere. More protection was demanded by those interested in the land, and accordingly a duty of $24 s$. $3 d$. was imposed when the price was $63 s$. or under; a bounty was paid on export when it was 4 os. or under; and wheat might be exported without bounty up to 54 s.

However, 1804 was a very deficient harvest, owing to blight and mildew, and by the end of the year wheat was $86 \mathrm{~s} .2 \mathrm{~d}$. The harvests till I 808 were not as bad as that of I804, but not good enough to lower the prices. Also, owing to the Berlin and Milan Decrees of Napoleon and the Non-intercourse Act of the United States of America, imports were restricted so that at the end of I 808 wheat was $92 s$. In this year the exports of wheat exceeded the imports, but it was due to the requirements of our army in Spain; and I $28 \mathrm{~g}$ was the last year when exports were greater under normal circumstances. ${ }^{3}$ I809 was a bad harvest, so was I8Io; in the former rot being very prevalent among sheep; and by August, I810, hay was $f$ II a load and wheat II $6 s$, only large imports ( $1,567,126$ quarters) preventing a famine. Down wool was 2s. I $d$. per lb., beef and mutton $8 \frac{1}{2} d$., cheese $8 d .4$

1 Tooke, History of Prices, i. 236.

2 Thorold Rogers, Work and Wages, c. I8. In many cases he was getting $15 s$. and $16 s$. a week all the year round. The Parliamentary Committee of 1822 put his wages during the war at from I5s. to I6s. a week. Parliamentary Reports Committees, v. 72 ; but it is difficult to say how much he received as wages, and how much as parish relief. Recruiting for the war helped to raise wages, as did the increased growth of corn.

${ }^{3}$ McCulloch, Commercial Dictionary (1847), p. 438. See Appendix, ii.

- Tooke, i. 319, and Pamphleteer, vi. 200 (A. Young). Since 1770, says the latter, labour by I8Io-1 I had doubled, but meat had risen 146 per cent., cheese 153 per cent., bread 100 per cent. Wages therefore had not risen in proportion to prices. 
In 1811 the whole of July and part of August were wet and cold; and in August, 18 12 , wheat averaged $155 \mathrm{~s}$., the finest Dantzic selling at Mark Lane for 180 s., and oats reached 84 s. As our imports of corn then chiefly came from the north-west of Europe, which has a climate very similar to our own, crops there were often deficient from bad seasons in the same years as our own, and the price consequently high. On the other hand, it is a proof that produce will find the best market regardless of hindrances, that much of our corn at this time came from France. Corn in $18 \mathrm{I} 2$ was seized on with such avidity that there was no need to show samples. As high prices had now prevailed for some time and were still rising, landlords and farmers jumped to the conclusion that they would be permanent; so that this is the period when rents experienced their greatest increase, in some cases having increased fivefold since $I 790$, and speculations in land were most general. Land sold for forty years' purchase, many men of spirit and adventure very different from farmers 'were tempted to risk their property in agricultural speculations ${ }^{1}$,' and large sums were sunk in lands and improvements in the spirit of mercantile enterprise. The land was considered as a kind of manufacturing establishment, and 'such powers of capital and labour were applied as forced almost sterility itself to become fertile.' Even good pastures were ploughed up to grow wheat at a guinea a bushel, and much worthless land was sown with corn. Manure was procured from the most remote quarters, and we are told a new science rose up, agricultural chemistry, which, ' with much frivolity and many refinements remote from common sense, was not without great operation on the productive powers of land.'

Land jobbing and speculation became general, and credit came to the aid of capital. The larger farmers, as we have seen, were before the war inclined to an extravagance that amazed their older contemporaries; now we are told, some

${ }^{1}$ Inquiry into Agricultural Distress (1822), p. 38. 
insisted on being. called esquire, and some kept liveried servants. ${ }^{1}$

It is somewhat curious to learn that one of the drawbacks from which farmers suffered at this time was the ravages of pigeons, which seem to have been as numerous as in the Middle Ages, when the lord's dovecote was the scourge of the villein's crops. In $18 \mathrm{I}_{3}$ there was said to be 20,000 pigeon houses in England and Wales, each on an average containing I00 pairs of old pigeons. ${ }^{2}$

Another pest was the large number of 'vermin', whose destruction had long before been considered important enough to demand the attention of the legislature. ${ }^{3}$ Some parishes devoted large portions of their funds to this object; in 1786 East Budleigh in Devonshire, out of a total receipt of $£ 20$ Is. $8 \frac{1}{2} d$., voted $£ 5$ IOs. for vermin killing. That now sacred animal the fox was then treated with scant respect, farmers and landlords paying for his destruction as 'vermin' 4 ; the parish accounts of Ashburton in Devonshire, for instance, from $1761-1820$ include payments for killing 18 foxes and 4 vixens, with no less than $I_{53}$ badgers.

But the edifice of artificial prosperity was already tottering. ! After 1812 prices fell steadily, ${ }^{5}$ the abundant harvest of 1813 and the opening of the continental ports accelerated this, and by December, $18 \mathrm{I}_{3}$, wheat was $73 s .3 d$. Yet agriculture had made solid progress. The Committee of the House of Commons which inquired into the state of the corn trade in 1813 stated that through the extension of, and improvements in, agriculture the agricultural produce of the kingdom had increased one-fourth in the preceding ten years. ${ }^{\circ}$ The high

${ }^{1}$ Thoughts on Present Depressed State of Agricultural Industry (1817), p. 6.

2 Vancouver, General View of the Agriculture of Devon, p. 357.

${ }^{3}$ See 14 Eliz., c. 11, and 39 Eliz., c. I8.

- Transactions of the Devon Association, xxix. $291-349$.

- Average annual prices of wheat were: 1812, 126s. 6d.; 1813, 109s. $9 d$; $1814,74 s .4 d . ; 1815,65 s .7 d$.

6 Porter, Progress of the Nation, p. 149. 
prices had attracted a large amount of capital to the land, so that there was very rapid and extensive progress, the methods of tillage were improved, large tracts of inferior pasture converted into arable, much, however, of which was soon to revert to weeds; there were many enclosures, and many fens, commons, and wastes reclaimed. But there was a reverse side to this picture of prosperity, even in the case of landlord and farmer. The burden of taxation was crushing; a contemporary writer, a farmer of twenty-five years standing, ${ }^{1}$ wrote that, with the land tax remaining the same, there was a high property tax, house and window taxes were doubled, poor rates in some places trebled, highway, church, and constable rates doubled and trebled, and there were oppressive taxes on malt and horses, both nags and farm animals. A man renting a farm at $£ 70$ and keeping two farm-horses, a nag, and a dog, would pay taxes for them of $£_{5}$ os. $6 d$., a fourteenth of his rent. $^{2}$ Indeed, poor rates of $16 s$. and 20s. in the $£$ were known, ${ }^{3}$ and they were occasionally more than the whole rent received by the landlord forty years before. A Devonshire landowner complained that seven-sixteenths out of the annual value of every estate in the county was taken from owners and occupiers in direct taxes. ${ }^{4}$ And the Committee on Agri-, cultural Depression of 1822 asserted that during the war taxes and rates were quadrupled. ${ }^{5}$ Blacksmiths, whitesmiths, collar makers, ropers, carpenters, and many other tradesmen with whom the farmer dealt, raised their prices threefold; and it was openly asserted that the high prices of grain and stock were not proportionate to the increase of other prices. Much of the grass land broken up in the earlier years of the war was before the close in a miserable condition, for it was cropped year after year without manure, and was worn out. On the

1 A Defence of the Farmers and Landowners of Great Britain (1814) p. 49 .
2 Ibid. p. $x$.
3 Ibid. p. 7.
- Agricultural State of the Kingdom, p. 67.
- Parliamentary Reports (Committees), v. 72. 
whole it may be doubted if the bulk of the farmers of England made large profits during the war; many no doubt profited by the extraordinary fluctuations in prices, and it was those men who 'kept liveried servants'; but there must have been many who lost heavily by the same means, and the rise of rent, taxes, rates, labour, and tradesmen's prices largely discounted the prices of corn and stock. The landowners at this period have generally been described as flourishing at the expense of the community, but their increased rents were greatly neutralized by the weight of taxation and the general rise in prices. A contemporary writer says that owing to the heavy taxes, even in the war time, he 'often had not a shilling at the end of the year.' 1

The following accounts, drawn up in $1805,{ }^{2}$ do not show that farmers were making much money with wheat at Ios. a bushel:

Account of the culture of an acre of wheat on good fallow land:

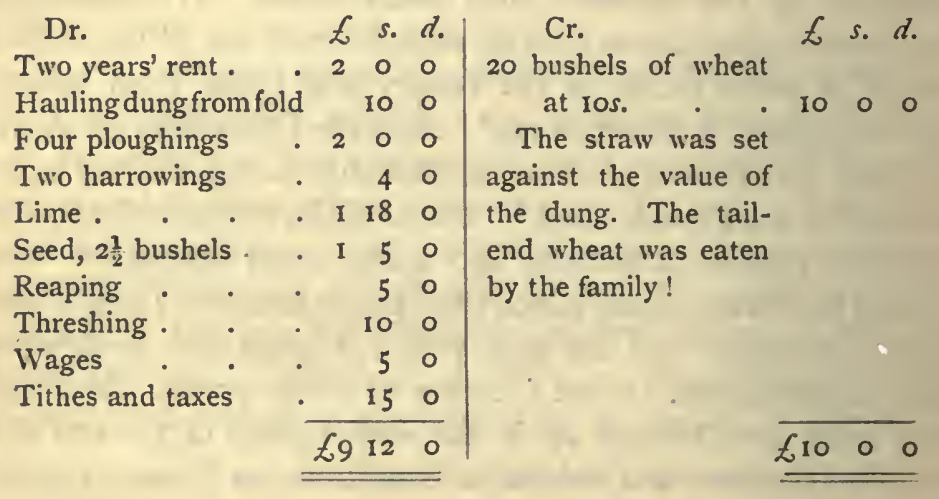

1 Thoughts on the Present Depressed State of the Agricultural Interest (1817), p. 4 .

2 Duncumb, General View of the Agriculture of Hereford, 1805. The writer of $A$ Defence of the Farmers and Landowners of Great Britain (1814) puts the average crop of wheat in the United Kingdom at 15 or 16 bushels an acre, p. 28. A very low estimate. 
And on a farm on good land in the same county the following would be the annual balance sheet at the same date :

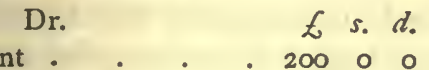

Tithes. . . 4000

Wages . . . 58 ० 5

Extra harvestmen.$\quad \begin{array}{lll}7 & 0 & 0\end{array}$

Tradesmen's bills . 5000

Taxes and rates. . $58 \circ 0$

Malt, hops, and cider. $60 \quad 0 \quad 0$

Lime . . . 2000

Hop poles . . . 1000

Expenses at fairs and

markets . . 800

Clothing,groceries, \&c.,

for the family $\quad 45 \circ \circ$

Interest on $£_{1,500 \text { capi- }}$ tal, at 5 per cent.

Sundries

$\begin{array}{r}7500 \\ 1500 \\ \hline 64600\end{array}$

Cr. 360 bushels of wheat,

(a) Ios.. . . 18000

300 bushels of barley,

(a) $6 s$.

100 bushels of peas,

@ 6s.

$20 \mathrm{cwt}$. hops

Sale of oxen, cows, and

calves.

Profits from sheep $\quad$ I00 0 ०

, from pigs, poul-

try, dairy, and sundries
Es. $d$.

9000

3000

6000

150.00

5000

$£ 660$ o 0

According to this the farmer did little more than pay rent, interest on capital, and get a living. Yet prices of what he had to sell had gone up greatly: wheat in Herefordshire in 1760 was 3 s. a bushel, in 1805 , IOs.; butcher's meat in 1760 was $\mathrm{I} \frac{1}{2} d$. a lb., in $1804,7 d$; ; fresh butter $4 \frac{1}{2} d$. in $1760,1 s .3 d$. in 1804 ; a fat goose in Hereford market in 1740, Iod.; I 760 , Is. ; 1804, 4 s.; a couple of fowls in $1740,6 d$. ; $1760,7 d . ; 1804,2 s .4 d_{0}{ }^{1}$

The winter of $1813-4$ was extraordinarily severe, and the wheat crop was seriously injured, but the increased breadth of cultivation, a large surplus, and great importations kept the price down. Many sheep, however, were killed by the hard winter, which also reduced the quality of the cattle, so that meat was higher in 1814 than at any previous period. At Smithfield beef was $6 s$. to $7 s$. a stone, mutton $7 s$. to $8 s .6 d$. With the peace of $18{ }_{14}$ the fictitious prosperity came to an

1 Duncumb, General Vierw of the Agriculture of Hereford, p. 140.

2 Tooke, History of Prices, ii. 4. 
end, a large amount of paper was withdrawn from circulation, which lowered the price of all commodities, and a large number of country banks failed. The first sufferers were the agricultural classes, who happened at that time to hold larger supplies than usual, the value of which fell at once; the incomes of all were diminished, and the capital of many annihilated. ${ }^{1}$ At the same time the demand for our manufactures from abroad fell off; the towns were impoverished, and bought less from the farmer.

The short period of war in I8I 5 had little effect on prices, and in January, 1816 , wheat was $52 s .6 d$, and the prices of live stock had fallen considerably. In $18 \mathrm{I} 5$ protection reached its highest limit, the Act of that year prohibiting import of wheat when the price was under 80 s. a quarter, and other grain in proportion. ${ }^{2}$ However, it was of no avail; and in the beginning of I 816 the complaints of agricultural distress were so loud and deep that the Board of Agriculture issued circular letters to every part of the kingdom, asking for information on the state of agriculture.

According to the answers given, rent had already fallen on an average 25 per cent., and agriculture was in a 'deplorable state ${ }^{3}$.' Bankruptcies, seizures, executions, imprisonments, were rife, many farmers had become parish paupers. Rent was much in arrear, tithes and poor rates unpaid, improvements generally discontinued, live stock diminished; alarming gangs of poachers and other depredators ranged the country. The loss was greater on arable than on grass land, and 'flock farms' had suffered less than others, though they had begun to feel it heavily.

All classes connected with the land suffered severely; the landlords could not get many of their rents; the farmer's stock had depreciated 40 per cent. ${ }^{4}$; many labourers, who during the

1 Farmer's Magazine (1817), p. 69.

2 The duties were often evaded by smuggling; coasting vessels met the foreign corn ships at sea, received their cargoes, and landed them so as to escape the duty. 3 Agricultural State of the Kingdom, p. 5.

- Observations for the Use of Landed Gentlemen (1817), p. 7 . 
war had been getting from $15 s$. to $16 s$. a week and $18 s$. in summer, ${ }^{1}$ were walking the country searching for employment. Many tenants threw up their farms, and it was often noticed that landlords, 'knowing very little of agriculture and taken by surprise,' could not manage the farms thrown on their hands, and they went uncultivated. Some farmers paid up their rent to date, sold their stock, and went off without any notice; others, less scrupulous, drove off their stock and moved their household furniture in the night without settling. ${ }^{2}$

Farmers and landowners were asked to state the remedies required. Some asked for more rent reduction and further prohibition of import, but the most general cry was for the lessening of taxation.

A Herefordshire farmer ${ }^{3}$ stated that in $18 \mathrm{I} 5$ the taxes on a farm of 300 acres in that county were:

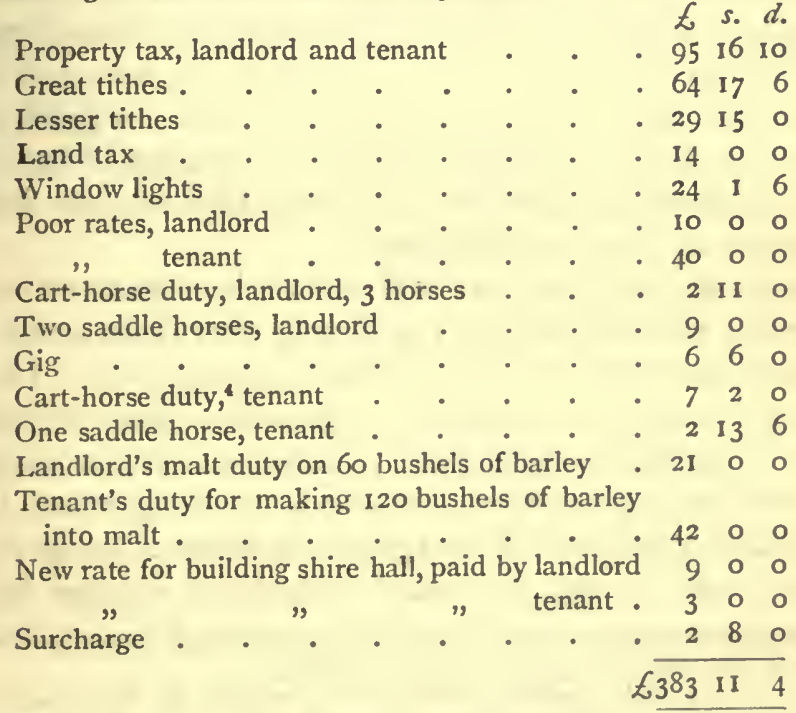

1 Defence of the Farmers, Eoc. (1814); and Parliamentary Reports, v. 72. 2 Agricultural State of the Kingdom, p. 64. 3 Ibid, p. 105.

1. The agricultural horse tax was repealed in 1821 , the tax on ponies and mules in 1823 . 
The parish of Kentchurch, in Herefordshire, paid in direct taxes a greater sum than the lands of the whole parish could be let for.

Another very general complaint was of the collection of tithe in kind, a most awkward and offensive method, causing great expense and waste, which, however, had given way in many places to compounding.

Such is the picture of agriculture after twenty years of high prices and protection. ${ }^{1}$ One may naturally ask, if much money had been made by farmers during these years, where had it all gone to that they were reduced at the first breath of adversity to such straits? Some allowance must be made for the fact that these accounts come from those interested in the land, who were always ready to make the most of misfortune with a view to further protection, and the farmer is a notorious grumbler. It seems, however, that most landlords and tenants believed that the high prices would last for ever, and lived accordingly, and, as we have seen, many made no profit at all because of their increased burdens. As a matter of fact, both were grumbling because prices had come back to their natural level after an unnatural inflation. ${ }^{2}$

Hemp at this date was still grown in Lincolnshire and Somerset, and Marshall tells us that in 1803 there was a considerable quantity of hemp grown in Shropshire. ${ }^{3}$ In that county there was a small plot of ground, called 'the hempyard,' appendant to almost every farm-house and to many of the best sort of cottages. Whenever a cottager had Io or I5 perches of land to his cottage, worth from '1s. $6 d$. to $2 s .6 d$. a year, with the aid of his wife's industry it enabled him to

1 There were some exceptions, but the overwhelming majority of replies to the letters were couched in the above spirit.

${ }^{2}$ At a time when landlords formed the majority in Parliament, it is curious to find a substantial farmer asserting that 'the landed interest has been, since the corn law of 1773 , held in a state of complete vassalage to the commercial and manufacturing, and the farmers of the country in a state very little superior to that of Polish peasants.'

3 Review of Western Department, pp. 249, 250. 
pay his rent. A peck of hempseed, costing 2s., sowed about io perches of land, and this produced from 24 to $36 \mathrm{lb}$. of tow when dressed and fit for spinning. A dozen pounds of tow made ro ells of cloth, worth generally about $3 s$. an ell. Thus a good crop on Io perches of land brought in $£ 4$ Ios. Od., half of which was nett profit. The hemp was pulled a little before harvest, and immediately spread on grass land, where it lay for a month or six weeks. The more rain there was the sooner it was ready to take off the grass. When the rind peeled easily from the woody part, it was, on a dry day, taken into the house, and when harvest was over well dried in fine weather and dressed, being then fit for the tow dresser, who prepared it for spinning. After the crop of hemp the land was sown with turnips, a valuable resource for the winter.

Since 18I 5 little hemp or flax has been grown in England ${ }^{1}$; in 1907 there were, according to the Agricultural Returns, 355 acres of flax grown in England, and hemp was not mentioned.

1 Morton, Cyclopaedia of Agriculture, ii. 26. 


\section{CHAPTER XVIII}

\section{ENCLOSURE-THE SMALL OWNER}

THE war period was one of great activity in enclosure; from I798 to I8 ro there were 956 Bills ; from I8II-20, 77I. ${ }^{1}$

It must be remembered, however, that the number of Acts is not a conclusive test of the amount of enclosure, as there was a large amount that was non-parliamentary: by the principal landlord, and by freeholders who agreed to amicable changes and transfer, as at Pickering, in Yorkshire. ${ }^{2}$ Roughly speaking, about one-third of the Acts were for enclosing commonable waste, the rest for enclosing open and commonable fields and lands. ${ }^{3}$ Owing to the expense an Act was only obtained in the last resource. It was also because of the expense 4 that many landlords desirous to enclose were unable to do so, and therefore devoted their attention to the improvement of the common fields. That agriculture benefited by enclosure there is no possible doubt, but it was attended with great hardships. The landowner generally gained, for his rents increased largely. In twenty-three parishes of Lincolnshire, for instance, his rents doubled on enclosure. But the expenses were so heavy that his gain was often very small, and sometimes he was a loser by the process. As for the farmers, the poorer ones suffered, for more capital was needed for enclosed lands, and the process generally was so slow, taking

1 Cf. supra. p. 163.

2 R. Marshall, Rural Economy of Yorkshire, p. 17 et seq.

3 Slater, English Peasantry and Enclosure, p. 7.

4 It was stated in the Report of the Committee on Enclosures (1844), p. 3I, that the ordinary expense of obtaining an Enclosure Act was from $£ I, 000$ to $£ 1,500$. In 1814 the enclosure of three farms, amounting to 570 acres, including subdivision fences and money paid to a tenant for relinquishing his agreement, cost the landlord nearly $£ 4,000$.Agricultural State of the Kingdom (1816), p. 116. 
from two to six years before the final award was given, that many farmers were thrown out in the management of their farms, for they did not know where their future lands would be allotted. That the poor suffered greatly is indubitable: 'By nineteen Enclosure Acts out of twenty the poor are injured, in some cases grossly injured,' wrote Young in 1801.1 In the Acts it was endeavoured to treat them fairly, ${ }^{2}$ and allotments were made to them, or money paid on enclosure in lieu of their rights of common, or small plots of land; but the expense of enclosing small allotments was proportionately very great, generally too great, and they had to be sold, while the sums of money were often spent in the alehouse. The results of sixty-eight Acts were investigated in the eastern counties, with the result that in all but fifteen the poor were injured. It was generally found that they had lost their cows.

Its effect on the small holder is well described by Davis in his Report on Wilts. ${ }^{3}$ There, before enclosure, the tenants usually occupied yard-lands consisting of a homestead, 2 acres of meadow, 18 acres of arable, generally in eighteen or twenty strips, with a right on the common meadows, common fields and downs for 40 sheep, and as many cattle as the tenant could winter with the fodder he grew. The 40 sheep were kept by a common shepherd with the common herd, were taken every day to the downs and brought back every night to be folded on the arable fields, the rule being to fold $\mathrm{I}, 000$ sheep on a 'tenantry' acre (three-quarters of a statute acre) every night." In breeding sheep regard was had to 'folding

1 Enquiry into the Propriety of Supplying Wastes to the better Support of the Poor, p. 42.

2 The usual clause in Enclosure Acts stated that the land should be - allotted according to the several and respective rights of all who had rights and interests' in the enclosed property, and expenses were to be borne 'in proportion to the respective shares of the people interested'.

${ }^{3}$ pp. 8 et seq. Slater, op. cit. p. 113.

4 Cf. Marshall's account of the common-field townships in Hampshire at the end of the eighteenth century. Each occupier of land in the 
quality,' i.e. the propensity to drop manure only after being folded at night, as much as to quality and quantity of wool and meat. On enclosure the common flock was broken up. The small farmer had no longer any common to turn his horses on. The down on which he fed his sheep was largely curtailed, the common shepherd was abolished, and the farmer had too few sheep to enable him individually to employ a shepherd. Therefore he had to part with his flock. Having no cow common and very little pasture land he could not keep cows. In such circumstances the small farmer, after a few years, succumbed and became a labourer, or emigrated, or went to the towns.

In a pamphlet called The Case of Labourers in Husbandry, I795, the Rev. David Davies said, 'by enclosure an amazing number of people have been reduced from a comfortable state of partial independence to the precarious condition of mere hirelings, who when out of work immediately come on the parish.' It has often been said that the poor were robbed of their share in the land by the landowners ; but as a matter of fact it was the expense of securing the compensation allowed them, much greater in proportion on small holdings than on large, which went into the pockets of surveyors and lawyers, that did this. It was also often through the farmer that the labourer was deprived of his land when he had retained an acre or two after enclosure. Wishing to make the labourer dependent on him, he persuaded the agent to let the cottages with the farm, and the agent in order to avoid collecting a number of small rents consented. As soon as the farmer had the cottages he took the land common fields contributed to the town flock a number of sheep in proportion to his holding, which were placed under a shepherd who fed them and folded them on all parts of the township. A similar practice was observed with the common herd of cows, which were placed under one cowherd who tended them by day and brought them back at night to be milked, distributing them among their respective owners, and in the morning they were collected by the sound of the horn. -Rural Economy of Southern Counties, ii. 35 I. 
from them and added it to his own. The peasant's losses engaged the serious attention of many landlords; near Tewkesbury, in 1773 , the lord of the manor on enclosure, besides reserving 25 acres for the use of the poor, allowed land to each cottage sufficient to keep a horse or a cow, often added a small building, and gave stocks for raising orchards. Even some of the idlest were thereby made industrious, poor rates sank to $4 d$. in the $£$, though the population increased, and the labourer always had for sale some poultry, or the produce of his cow, or some fruit. ${ }^{1}$

In I 800 the Board of Agriculture, composed almost entirely of landowners, noticing that the poor of Rutland and Lincolnshire, who had land for one or two cows and some potatoes, had not applied for poor relief, offered a gold medal for the most satisfactory account of the best means of supporting cows on poor land, in a method applicable to cottagers. ${ }^{2}$ Young recommended that in the case of extensive wastes every cottage on enclosure should be secured sufficient land on which to keep a cow, the land to be inalienable from the cottage and the ownership vested in the parish.

Lord Winchelsea ${ }^{3}$ urged that a good garden should always go with a cottage, and set the example himself, one which has been generally followed in England by the greater landlords with much success. As may be imagined, these schemes or others similar to them were put into effect by the conscientious and energetic, but not by the apathetic and careless. Further, an Act was passed in the fifty-ninth year of George III, which enabled parishes to lease or buy 20 acres of land for the employment of their poor.

1 Report of Committee on Waste Lands (1795), p. 204. Ground was frequently left by the Acts for the erection of cottages for the poor, and special allotments were made to Guardians for the use of the poor, in addition to the land allotted to all according to their respective claims. Can any one doubt that if there had been a systematic robbery of the smaller holders on enclosure they would not have risen 'en masse'?

2 Slater, op. cit. p. 133.

3 Agricultural State of the Kingdom (1816), p. 8. 
In many cases, it must be allowed, the grazing of the commons was often worth very little. Let one man, it was said in 1795 , put a cow on a common in spring for nothing, and let another pay a farmer Is. $6 d$. a week to keep a cow of equal value on enclosed land. When both are driven to market at Michaelmas the extra weight of the latter will more than repay the cost of the keep, while her flow of milk meanwhile has been much superior.

The Committee on Waste Lands of 1795 attributed the great increase in the weight of cattle not only to the improved methods of breeding, but to their being fed on good enclosed lands instead of wastes and commons. ${ }^{1}$ Even when commons were stinted they were in general overstocked, while disease was always being spread with enormous loss to the commoners. The larger holders, too, who had common rights, often crowded out the smaller.

There were often, as we have seen, a large number of 'squatters' on commons who had seized and occupied land without any legal title. As a rule, if these people had been in possession twenty-one years their title was respected; if not, no regard was very justly paid to them on enclosure, and they were deprived of what they had seized.

Eden wrote when enclosure was at its height; he was a competent and accurate observer, and this is his picture of the 'commoner' ${ }^{2}$ 'The advantages which cottagers and poor people derive from commons and wastes are rather apparent than real; instead of sticking regularly to labour they waste their time in picking up a few dry sticks or in grubbing on some bleak moor. Their starved pig or two, together with a few wandering goslings, besides involving them in perpetual altercations with their neighbours, are dearly paid for in care, time, and bought food. There are thousands and thousands of acres in the kingdom, now the 
sorry pastures of geese, hogs, asses, half-grown horses, and half-starved cattle, which want but to be enclosed to be as rich as any land now in tillage.'

Enclosure worked an important social revolution. Before it the entirely landless labourer was rare: he nearly always had some holding in the common field or a right on the common pasture. With enclosure his holding or right had generally disappeared, and he deteriorated socially. It was very unfortunate, too, that when enclosure was most active domestic industries, such as weaving, decayed, and deprived the labourer and his family of a badly needed addition to his scanty income.

In its physical and moral effects the system of domestic manufactures was immensely preferable to that of the crowded factory, while economically it enabled the tillers of the soil to exist on farms which could not support them by agriculture alone.

This uprooting of a great part of the agricultural population from the soil by irresistible economic causes brought with it grave moral evils, and created divisions and antagonisms of interest from which we are suffering to-day. ${ }^{1}$ If some such scheme as that of Arthur Young or Lord Winchelsea had been universally adopted, this blot on an inevitable movement might have been removed, and a healthy rural population planted on English soil. Another result followed, the labourer no longer boarded as a rule in his employer's house, where the farmer worked and lived with his men; the tie of mutual interest was loosened, and he worked for this or that master indifferently. One advantage, however, arose, in that, having to find a home of his own, he married early, but this was vitiated by his knowledge that the parish would support his children, on which knowledge he was induced to rely.

On the other hand, the farmer often rose in the social scale. I

${ }_{1}^{1}$ Lecky, England in the Eighteenth Century, vi. 191. 
With the abandonment of the handicaps and restrictions of the common-field system the efficient came more speedily to the front. It was they who had amassed capital, and capital was now needed more than ever, so they added field to field, and consolidated holdings.

The Act of 1845 did away with the necessity for private Enclosure Acts, still further reducing the expense ; and since that date there have been 80,000 or 90,000 acres of common arable fields and meadows enclosed without parliamentary sanction, and 139,517 acres of the same have been enclosed with it, ${ }^{1}$ besides many acres of commons and waste.

In the Report of the Committee of Enclosures of $1844,{ }^{2}$ there is a curious description of the way in which common fields were sometimes allotted. There were in some open fields, lands called 'panes', containing forty or sixty different lands, and on a certain day the best man of the parish appeared to take possession of any lot he thought fit. If his right was called in question there was a fight for it, and the survivor took the first lot, and so they went on through the parish. There was also the old 'lot meadow' in which the owners drew lots for choice of portions. On some of the grazing lands the right of grazing sheep belonged to a man called a 'flockmaster', who during certain months of the year had the exclusive right of turning his sheep on all the lands of the parish.

Closely connected with the subject of enclosure is that of the partial disappearance of the small owner, both the yeoman who farmed his own little estate and the peasant proprietor. We have noticed above ${ }^{3}$ Gregory King's statement as to the number of small freeholders in England in 1688 , no less than 160,000 , or with their families about oneseventh of the population of the country. This date, that

1 Slater, op. cit. p. I91.

2 Report, p. 27.

S See p. 156. Another estimate puts them at r80,000. 
of the Revolution, marks an epoch in their history, for from that time they began to diminish in proportion to the population. Their number in 1688 is a sufficient answer to the exaggerated statement of contemporaries in the sixteenth and seventeenth centuries as to the depopulation caused by enclosures. Chamberlayne, in his State of Great Britain, published at about the same time as Gregory King's figures, says there were more freeholders in England than in any country of like extent in Europe: ' $£ 40$ or $£ 50$ a year is very ordinary, $£ 100$ or $£ 200$ in some counties is not rare, sometimes in Kent and in the Weald of Sussex $£ 500$ or $£ 600$ per annum, and $£ 3,000$ or $£ 4,000$ of stock.' In the first quarter of the eighteenth century he was a prominent figure. Defoe ${ }^{1}$ describes the number and prosperity of the Greycoats of Kent (as they were called from their homespun garments), 'whose interest is so considerable that whoever they vote for is always sure to carry it.'

Why has this sturdy class so dwindled in numbers, and left England infinitely the weaker for their decrease? The causes are several; social, economic, and political. The chief, perhaps, is the peculiar form of Government which came in with the Revolution. The landed gentry by that event became supreme, the national and local administration was entirely in their hands, and land being the foundation of social and political influence was eagerly sought by them where it was not already in their hands. ${ }^{2}$ At the same time the successful business men, whose numbers now increased rapidly from the development of trade, bought land to 'make themselves gentlemen'. Both these classes bought out the yeomen, who do not seem to have been very' loath to part with their land. The recently devised system of strict family settlements enabled the old and the new

3 Tour, i. (2), 37, 38.

2 Toynbee, Industrial Revolution, p. 62. 
gentlemen to keep this land in their families. The complicated title to land made its transfer difficult and costly, so that there was little breaking up of estates to correspond with the constant buying up of small owners. To the smaller freeholder, as has been noticed, the enclosure of waste land did much harm, for it was necessary to his holding. Again, smaller arable farms did not pay as well as large ones, so they tended to disappear. The decay of home industries was also a heavy blow to the smaller yeoman and the peasant proprietor.

Under this combination of circumstances many of the yeomen left the land. Yet though Young, less than a century after King and Davenant, said that the small freeholder had practically. disappeared, there were at the end of the eighteenth century many left all over England, who however largely disappeared during the war and in the bad times after the war. ${ }^{1}$ But a contrary tendency was at work which helped to replenish the class. The desire of the Englishman for land is not confined to the wealthy classes. At the end of the eighteenth century men who had made small fortunes in trade were buying small properties and taking the place of the yeomen. ${ }^{2}$ In the great French War of I793-I8I5, many yeomen, attracted by the high prices of land, sold their properties, but at the same time many farmers, attracted by the high prices of produce, which had often enriched them, bought land. ${ }^{3}$ During the 'good times' of I853-75 many small holders, like those of Axholme, noticed in the Report of the Agricultural Commission of I 893 , bought land.

A new class of small owners also has sprung up, who, dwelling in or near towns and railway stations, have bought small freeholds. The return of the owners of land of $1872-6$

1 Hasbach, op. cit. p. 71 .

2 Marshall, Review of Agriculture, Reports Western Department, p. I8.

s Parliamentary Reports, Commissioners (1897), xv. 32. 
gave the following numbers of those owning land in England and Wales ${ }^{1}$ :

Number. Acreage.

Total number of owners of less than one acre $\cdot 703,289$ I 51,171

\begin{tabular}{|c|c|c|c|c|c|c|}
\hline & & & and & er 10 & I 21,98 & 478,679 \\
\hline & $"$ & I0 & $"$ & 50 & $72,64 c$ & $\mathrm{I}, 750,079$ \\
\hline & ", & 50 & $"$ & 100 & 25,83 & $\mathrm{I}, 79 \mathrm{I}$ \\
\hline & " & 100 & ", & 500 & $32,3 \mathrm{I}_{2}$ & \\
\hline
\end{tabular}

The great majority of the first class here enumerated, those owning less than one acre, do not concern us, as they were evidently merely houses and gardens not of an agricultural character, but a large number of the second class and most of the other three must have been agricultural, though unfortunately no distinction is made. It will be seen, therefore, that there were a considerable number of small owners in England in 1872 , and their numbers have probably increased since. Many of them, however, are of the new class mentioned above, and there appears to be no doubt that the number of the peasant proprietors and of the yeomen of the old sort has much diminished, especially in proportion to the growth of population.

1 Parliamentary Accounts and Papers, 1xxx. 21. The number of those owning over 500 acres does not concern the small owner or the yeoman class, but they were: from 500 acres to $1,000,4,799$; from 1,000 to 2,000 , 2,7 I9; from 2,000 to $5,000,1,815$; from 5,000 to $10,000,581$; from 10,000 to $20,000,223$; from 20,000 to $50,000,66$; from 50,000 to $100,000,3$; over 100,000, I. For the numbers of the 'holdings' of various sizes in 1875 and 1907 see below, p. 334. The term 'holdings', however, includes freeholds and leaseholds. 


\section{CHAPTER XIX \\ I 8 I $6-1837$}

\section{DEPRESSION}

THE summer of 1816 was wretched; the distress, aggravated by the bad season, caused riots everywhere. At Bideford the mob interfered to prevent the export of a cargo of potatoes ; at Bridport they broke into the bakers' shops. Incendiary fires broke out night after night in the eastern counties. At Swanage six people out of seven were paupers, and in one parish in Cambridgeshire every person but one was a pauper or a bankrupt. ${ }^{1}$ Corn rose again: by June, 1817 , it was $117 \mathrm{~s}$., but fell to $77 s$. in September.

In 1818 occurred a drought of four months, lasting from May till September, and great preparations were made to ward off the expected famine; immense quantities of wheat came from the Baltic, of maize from America, and beans and maize from Italy and Egypt, with hay from New York, as it was selling at $£ 10$ a ton. However, rain fell in September, brown fields suddenly became green, turnips sprang up where none had appeared, and even spring corn that had lain in the parched ground began to grow, so the fear of scarcity passed.

In 1822 came a good season, which produced a great crop of wheat; in the lifetime of the existing generation old men declared that such a harvest had been known only once before; imports also came from Ireland to the amount of nearly a million quarters, so that the price at the end of the year was $38 s$, and the average price for the year was $44 s .7 d$. Beef went down to $2 s .5 \mathrm{~d}$. a stone and mutton to $2 s$. $2 d$. The cry of agricultural distress again rose loudly. Farmers were ${ }^{1}$ Walpole, History of England, i. 161. 
still, though some of the war taxes had been remitted, heavily taxed; for the taxes on malt, soap, salt, candles, leather, all pressed heavily. ${ }^{1}$ The chief cause of the distress was the long-felt reaction after the war, but it was aggravated by the return to cash payments in 1819 . Gold had fallen to its real value, and the fall in gold had been followed by a fall in the prices of every other article. ${ }^{2}$ The produce of many thousand acres in England did not sell that year for as much money as was expended in growing it, without reckoning rent, taxes, and interest on capital. ${ }^{3}$ Estates worth $£_{3,000}$ a year, says the same writer, some years since, were now worth $£ \mathrm{I}, 000$. Bacon had gone down from $6 s .6 d$. to $2 s .4 d$. a stone; Southdown ewes from $50 s$. to $15 s$., and lambs from $42 s$. to $5 s$.

A Dorset farmer told the Parliamentary committee that since $18 \mathrm{I}_{5}$ he knew of fifty farmers, farming 24,000 acres, who had failed entirely. ${ }^{4}$

In the Tyne Mercury of October $30,182 \mathrm{r}$, it was recorded that Mr. Thos. Cooper of Bow purchased 3 milch cows and 40 sheep for $£$ I 8 I6s. $6 d$., which sum four years previously would only have bought their skins. Prime beef was sold in Salisbury market at $4 d$. retail, and good joints of mutton at $3 \frac{1}{2} d . .^{5}$ Everywhere the farmers were complaining bitterly, but ' hanging on like sailors to the masts or hull of a wreck'. In Sussex labourers were being employed to dig holes and fill them in again, proof enough of distress but also of great folly. Many thousands of acres were now a mass of thistles and weeds, once fair grass land ploughed up during the war for wheat, and abandoned at the fall of prices.

1 Inquiry into Agricultural Distress (1822), p. 40.

2 Walpole, op. cit. ii. 22.

3 A Letter to the Earl of Liverpool, by an Old Tory, 1822. The Committee on Agricultural Distress found that farmers were paying rent out of capital (Parliamentary Reports, Committees, v. 71), and that leases fixed on the basis of the high prices of the war meant ruin to the farmer if held to his engagement.

4 Parliamentary Reports, Committees, ix. 138.

${ }^{5}$ Cobbett, Rural Rides (ed. 1885), i. 3, 16. 
There were no less than 475 petitions on agricultural distress presented to the House from $I 820$ to March 21, I822. In 1822 it was proposed that the Government should purchase wheat grown in England to the value of one million sterling and store it; also that when the average price of wheat was under 6os. the Government should advance money on such corn grown in the United Kingdom as should be deposited in certain warehouses, to an extent not exceeding two-thirds the value of the corn. ${ }^{1}$ There were not wanting men, however, who put the other side of the question. In a tract called The Refutation of the Arguments used on the Subject of the Agricultural Petition, written in 1819, it was said that the increase in the farmer's expenditure was the cause of his discontent. 'He now assumes the manners and demands the equipage of a gentleman, keeps a table like his landlord, anticipates seasons in their productions, is as choice in his wines, his horses, and his furniture.' Let him be more thrifty. 'Let him dismiss his steward, a character a few years back only known to the great landowner, and cease from degrading the British farmer into a synonym for prodigality.' Lord Liverpool, in the House of Lords, in a speech which roused great opposition among agriculturists, minimized the distress ; distress there was, he admitted, but it was not confined to England, it was world-wide; neither was it produced by excessive taxation, for since I8I 5 taxation had been reduced 25 per cent., while though rents and prices had fallen they were much higher than before the war. Another writer said at the time, 'Individuals of all classes have of late been as it were inflated above their natural size: let this unnatural growth be reduced; let them resume their proper places and appearances, and the quantum of substantial enjoyment, real comfort and happiness, will not be found lessened.' It was also asserted that the taxes on malt, leather, soap, salt, and candles, were not very pressing.

${ }^{1}$ Report of the Committee on Agriculturul Depression (I 822), pp. 3, 4 . 
The persistent cries of distress produced a Bill giving still further protection to corn-growers, which was fortunately not carried into effect. There was no doubt, however, about the reality of the crisis through which the landed classes were passing. Many of the landowners were heavily in debt. Mortgages had been multiplied during the war, and while prices were high payment of interest was easy; but when prices fell and the tenant threw up his farm, the landlord could not throw over the mortgage, and the interest hung like a dead weight round his neck. ${ }^{1}$

The price to which wheat fell at the end of 1822 was to be the lowest for some years; it soon recovered, and until 1834 the average annual prices ranged from 53 s. to $68 \mathrm{~s}$. $6 d$., while in 1825 beef at Smithfield was $5 s$. and mutton $5 s .4 d$. a stone.

In 1823 there was a marked improvement, and the king's speech congratulated the country on 'the gradual abatement of those difficulties under which agriculture has so long suffered. ${ }^{2}$ In 1824 'agriculture was recovering from the depression under which it laboured.' 3 In 1825 it was said, 'there never was a period in the history of this country when all the great interests of the nation were in so thriving a condition.' ${ }^{4}$ In that year over-speculation produced a panic and agricultural distress was again evident. In 1825 Cobbett said, 'the present stock of the farms is not in one-half the cases the property of the farmer, it is borrowed stock.' ${ }^{3}$ In I 828 all the farmers in Kent were said to be insolvent. ${ }^{6}$

At the meeting of Parliament in 1830 the king lamented the state of affairs, and ascribed it to unfavourable seasons and other causes beyond the reach of legislative remedy. Many had learnt that high protection was no protection

1 Walpole, History of England, ii. 23.

2 Hansard, ix. 1544 .

1 Ibid. xii. I.

Ibid. X. I, 2.

5 Rural Rides, ii. 199.

6 Walpole, History of England, ii. 526. The distress was aggravated by rot among sheep, which is said to have destroyed one-fourth of those in the kingdom. See Parliamentary Reports, Commissioners (1836), viii (2), p. 198 . 
for farmers, and it was stated more than once that the large foreign supply of grain, though only then about one-third of the home-grown, depressed our markets. At the same time, it must be admitted that agriculture, like all other industries, was suffering from the crisis of 1825 . In 1830 , the country was filled with unrest, in which the farm labourer shared. His motives, however, were hardly political. He had a rooted belief that machinery was injuring him, the threshing machine especially; and he avenged himself by burning the ricks of obnoxious farmers. Letters were sent to employers demanding higher wages and the disuse of machines, and notices signed 'Swing' were affixed to gates and buildings. Night after night incendiary fires broke out, and emboldened by impunity the rioters proceeded to pillage by day. In Hampshire they moved in bodies I,500 strong. A special Commission was appointed, and the disorders put down at last with a firm hand. In 1828 there had been a relaxation in the duties on corn, the object of the Act passed in that year being to secure the farmer a constant price of $8 s$. a bushel instead of IOs. as in I8I5, and by a sliding scale to prevent the disastrous fluctuations in prices. The best proof of its failure is afforded by the appointment of another parliamentary committee in I833 to inquire into the distressed state of agriculture. At this inquiry many witnesses asserted that the cultivation of inferior soils and heavy clays had diminished from one-fourth to one-fifth. ${ }^{1}$ It was also asserted that farmers were paying rent out of capital. ${ }^{2}$ Tooke, however, thought there was much exaggeration of the distress, which was proved by the way the farmers weathered the low prices of 1835 , when wheat, after a succession of four remarkably good seasons, averaged $39 s .4 d$. for the year. In these abundant years, too, he asserts that the home supply was equal to the demand, ${ }^{3}$ though the committee of 1833 had

1 Tooke, History of Prices, ii. 227. 3 Tooke, History of Prices, ii. 238.

2 Report of 1833, p. 6. 
stated that this had ceased to be the case. ${ }^{1}$ Another committee, the last for many years, sat in 1835 to consider the distress; but although prices were low the whole tenor of the evidence established the improvement of farming, the extension of cultivation, and the increase of produce, and it was noticed at this time that towns dependent on agriculture were uniformly prosperous. ${ }^{2}$

On the whole, in spite of exaggeration from interested motives, the distress for the twenty years after the battle of Waterloo was real and deep; twenty years of depression succeeded the same period of false exaltation. The progress, too, during that time was real, and made, as was remarked, because of adversity. From this time agriculture slowly revived.

On one point both of the two last committees were agreed, that the condition of the labourer was improved, and they said he was better off than at any former period, for his wages remained the same, while prices of necessaries had fallen. That his wages went further is true, but they were still miserably low, and he was often housed worse than the animals on the farm. 'Wattle and dab' (or mud and straw) formed the walls of his cottage, the floors were often of mud, and all ages and both sexes frequently slept in one room. A block of ten cottages were put up in the parish of Holmer ${ }^{3}$

1 Imports fell considerably at this date; they were:

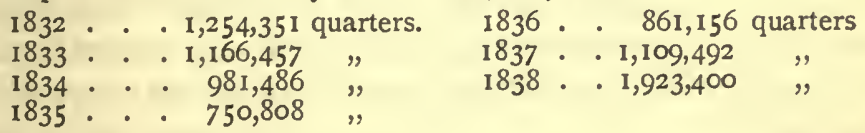

There were also considerable exports :

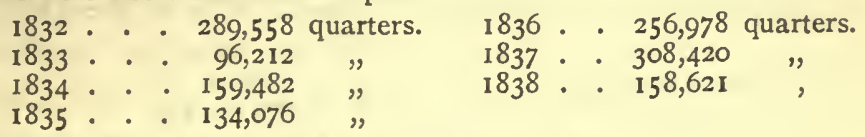

$\mathrm{M}^{\circ}$ Culloch, Commercial Dictionary (1847), p. 438.

2 Porter, Progress of the Nation, p. 15 I.

3 See Duncumb, General View of Herefordshire (1805). 
at the commencement of the nineteenth century, which were said to have combined 'comfort, convenience, and economy;' they each contained one room I 2 feet by 14 feet and 6 feet high with a bedroom over, and cost $£ 3^{2}$ Ios. each. They were evidently considered quite superior dwellings, far better than the ordinary run of labourer's cottages. Cobbett gives us a picture of some in Leicestershire in 1826 ; ' hovels made of mud and straw, bits of glass, or of old cast-off windows, without frames or hinges frequently, and merely stuck in the mud wall. Enter them and look at the bits of chairs or stools, the wretched boards tacked together to serve for a table, the floor of pebble, broken brick, or of the bare ground; look at the thing called a bed, and survey the rags on the backs of the wretched inhabitants.' 1 The chief exceptions to this state of affairs were the estates of many of the great landlords. On that of the Earl of Winchelsea in Rutland, the cottages he had built contained a kitchen, parlour, dairy, two bedrooms, and a cow-house, and several had small holdings attached of from 5 to 20 acres. $^{2}$ Not long before, wages in Hampshire and Wiltshire were $5 s$. and $6 s$. a week. ${ }^{3}$

In 1822 it was stated that 'beef and mutton are things the taste of which was unknown to the mass of labourers. No one has lived more in cottages than I, and I declare solemnly I never remember once to have seen such a thing.' 4

A group of women labourers, whom Cobbett saw by the roadside in Hampshire, presented 'such an assemblage of rags as I never saw before even amongst the hoppers at Farnham.' 5

The labourer's wages may have gone a little further, but he /

1 Rural Rides, ii. 348.

2 Loudon, Encyclopaedia of Agriculture (1831), p. 1156.

3 Cobbett, Rural Rides, i. I 49. The average, however, now was about 9s.; see Parliamentary Reports, v. 72.

A Letter to the Earl of Liverpool by an Old Tory (1822), p. 16.

- Rural Rides, i. 18. 
had lost his by-industries, his bit of land and rights of common, and would have had a very different tale to tell from that of the framers of the reports above quoted.

In spite of the complaints made that the improvements of the coaches and of the roads drew the countryman to the towns, many stirred hardly at all from their native parish, and their lives were now infinitely duller than in the Middle Ages. The great event of the year was the harvest home, which was usually a scene of great merry-making. In Devonshire, when a farmer's wheat was ripe he sent round notice to the neighbourhood, and men and women from all sides came to reap the crop. As early as eleven or twelve, so much ale and cider had been drunk that the shouts and ribald jokes of the company were heard to a considerable distance, attracting more helpers, who came from far and near, but none were allowed to come after I 2 o'clock. Between I 2 and I came dinner, with copious libations of ale and cider, which lasted till 2, when reaping was resumed and went on without interruption except from the squabbles of the company till 5 , when what were called 'drinkings', or more food and drink, were taken into the field and consumed. After this the corn reaped was bound into sheaves till evening, when after the sport of throwing their reaping hooks at a sheaf which had been set up as a mark for a prize, all proceeded to supper and more ale and cider till the small hours. ${ }^{1}$

No wages were paid at these harvestings, but the unlimited amount of eating and drinking was very expensive, and about this date the practice of using hired labour had largely superseded this old custom.

The close of this period was marked by two Acts of great benefit to farmers : the Poor Law Amendment Act of 1834 (4\& $5 \mathrm{Wm}$. IV, c. 76), which reduced the rates, ${ }^{2}$ and marked

\section{Moore, History of Devonshire, i. 430 .}

2 By this Act and the various amending Acts the law of settlement, so long a burden on the labourer, is now settled thus: a settlement may be 
'the beginning of a period of slow recovery in the labourer's standard of life, moral and material, though at first it brought him not a little adversity '; ${ }^{1}$ and the Tithe Commutation Act of 1836 ( $6 \& 7 \mathrm{Wm}$. IV, c. 7I), which substituted for the tithe paid in kind or the fluctuating commuted tithe, a tithe rent charge equivalent to the market value, on a septennial average, of the exact quantities of wheat, barley, and oats, which made up the legal tithes by the estimate in 1836 . Thus was removed a perpetual source of dispute and antagonism between tithe-payer and tithe-owner. The system hitherto pursued, moreover, was wasteful. In exceptionally favourable circumstances the clergy did not receive more than twothirds of the value of the tithe in kind. The delays were a frequent source of loss. In rainy weather, when the farmer desired to get his crops in quickly, he was obliged to shock his crops, give the tithe-owners notice to set out their tithes, and wait for their arrival; in the meantime the crop, perhaps, being badly damaged. ${ }^{2}$

acquired by birth, parentage, marriage, renting a tenement, by being bound apprentice and inhabiting, by estate, payment of taxes, and by residence. - Stephen, Commentaries on the Lawus of England (1903), iii. 8\%.

${ }^{1}$ Hasbach, op. cit. p. 217.

2 R.A.S.E. Journal (1901), p. 9. 


\section{CHAPTER XX}

I $837-1875$

\section{REVIVAL OF AGRICULTURE.-THE ROYAL AGRICULTURAL SOCIETY.-CORN LAW REPEAL.-A TEMPORARY SET-BACK.-THE HALCYON DAYS}

THE revival of agriculture roughly coincided with the accession of Queen Victoria.

It was proved that Scotch farmers who had farmed highly had weathered the storm. Instead of repeatedly calling on Parliament to help them they had helped themselves, by spending large sums in draining and manuring the land; they had adopted the subsoil plough, and the drainage system of Smith of Deanston, used machinery to economize labour, and improved the breed of stock. This was an object-lesson for the English farmer, and he began to profit by it. It was high time that he did. In spite of the undoubted progress made, farming was still often terribly backward. Little or no machinery was used, implements were often bad, teams too large, drilling little practised, drainage utterly inefficient; in fact, while one farmer used all the improvements made, a hundred had little to do with them. But better times were at hand.

About 1835 Elkington's system of drainage, which among the more advanced agriculturists, at any rate, had been used for half a century, was superseded by that of James Smith of Deanston, a system of thorough drainage and deep ploughing, which effected a complete revolution in the art of draining, and holds the field to-day. Hitherto the draining of land had been done by a few drains where they were thought necessary, which was often a failure. Smith initiated a complete system of parallel underground drains, near enough to each other to catch all the superfluous water, running into a main drain 
which ran along the lowest part of the ground. His system has also been called 'furrow or frequent draining', as the drains were generally laid in the furrows from two to two-anda-half feet deep at short intervals. Even then the tributary drains were at first filled in with stones 12 inches deep, as they had been for centuries, and sometimes with thorns, or even turves, as tiles were still expensive; and the main was made of stonework. However, the invention of machines for making tiles cheapened them, and the substitution of cylindrical pipes for horse-shoe tiles laid on flat soles still further lowered the cost and increased the efficiency. ${ }^{1}$ In $\mathrm{r} 848$, Peel introduced Government Drainage Loans, repayable by twentytwo instalments of $6 \frac{1}{2}$ per cent. This was consequently an era of extensive drainage works all over England, which sorely needed it; but even now the work was often badly done. In some cases it was the custom for the tenant to put in as many tiles as his landlord gave him, and they were often merely buried. At Stratfieldsaye, for instance, where the Iron Duke was a generous and capable landlord, the drains were sometimes a foot deep, while others were 6 feet deep and 60 feet apart, ${ }^{2}$ although the soil required nothing of the kind.

Vast 'sums were also spent on farm-buildings, still often old and rickety, with deficient and insanitary accommodation; in Devonshire the farmer was bound by his lease to repair 'old mud and wooden houses', at a cost of Io per cent. on his rent, and there were many such all over England. Farmbuildings were often at the extreme end of the holding, the cattle were crowded together in draughty sheds, and the farmyard was generally a mass of filth and spoiling manure, spoiling because all the liquid was draining away from it into the pool where the live stock drank; a picture, alas, often true to-day. It was to bring the great mass of landlords and

1 Cylindrical pipes came in about 1843 , though they had been recommended in 1727 by Switzer.

${ }^{2}$ R.A.S.E. Journal (Ist series), xxii. 260. 
farmers into line with those who had made the most of what progress there had been, that the Royal Society was founded in $183^{8}$, in imitation of the Highland Society, but also owing to the realization of the great benefits conferred on farming during the last half-century by the exertions of Agricultural Societies, the Smithfield Club Shows having especially aided the breeding of live stock.

Writing on the subject of the Society, Mr. Handley ${ }^{1}$ spoke of the wretched modes of farming still to be seen in the country, especially in the case of arable land, though there had been a marked improvement in the breeding of stock. Prejudice, as ever, was rampant. Bone manure, though in the previous twenty years it had worked wonders, was in many parts unused. It was felt that what the English farmer needed was 'practice with science'. The first President of the Society was Earl Spencer, and it at once set vigorously to work, recommending prizes for essays on twenty-four subjects, some of which are in the first volume of the Society's Journal. Prizes were also offered for the best draining-plough, the best implement for crushing gorse, for a ploughing match to be held at the first country meeting of the Society fixed at Oxford in 1839 , for the best cultivated farm in Oxfordshire and the adjacent counties, and for the invention of any new agricultural implement.

In 1840 the Society, was granted a charter under the title of the Royal Agricultural Society of England, and its career since then has been one of continued usefulnèss, and forms a prominent feature in the agricultural history of the times.

In $1839^{2}$ the first country meeting of the Society was held at Oxford, and its 247 entries of live stock and 54 of implements, were described as constituting a show of unprecedented magnitude. According to Bell's Weekly Messenger for July 22, I839, the show for some time had been the all-absorbing topic of conversation not only among

1 R.A.S.E. Journal, 1890, pp. I sq. $\quad{ }^{2}$ Ibid., 1894, pp. 205 sq. 
agriculturists, but among the community at large, and the first day 20,000 people attended the show, many having come great distances by road. Everybody and every exhibit had to get to Oxford by road; some Shorthorn cattle, belonging to the famous Thomas Bates of Kirkleavington, took nearly three weeks on the road, coming from London to Aylesbury by canal. But such a journey was not unusual then, for cattle were often two or three weeks on the road to great fairs, and stood the journey best on hay; it was surprising how fresh and sound they finished. ${ }^{1}$ The show ground covered 7 acres, and among the implements tested was a subsoil plough, Biddell's Scarifier, and a drill for depositing manure after turnips. There were only six classes for cattle-Shorthorns, Herefords, Devons, Cattle of any other breed, Dairy Cattle, and Oxen; one class for horses, and three for sheep-Leicesters, Southdown or other Short Wool, and Long Woolled; with one for pigs. ${ }^{2}$ The Shorthorns, with the exception of the Kirkleavingtons, were bred in the neighbourhood, and many good judges said long afterwards that a finer lot had not been seen since. The Duchesses especially impressed all who saw them. The rest of the live stock was in no way remarkable.

From this small beginning, then thought so much of, the show grew fast, and the Warwick meeting ${ }^{3}$ of 1892 , after several years of agricultural depression, illustrates the excellent work of the Society and the enormous progress made by English agriculture. The show ground covered 90 acres; horses were now divided into Thoroughbred Stallions, Hunters, Coach Horses, Hackneys, Ponies, Harness Horses and Ponies, Shires, Clydesdales, Suffolks, and Agricultural Horses. Cattle were classified as Shorthorns, Herefords, Devons, Sussex, Longhorns (described as few in number and of no particular quality, 'a breed which has now been many

${ }^{1}$ McCombie, Cattle and Cattle Breeders, p. 33.

2 These classes, however, did not comprise all the then known breeds of live stock.

${ }^{3}$ R. A.S.E. Journal, 1892, pp. 479 sq. 
years on the wane', but has recently been revived), ${ }_{1}^{1}$ Welsh, Red Polled, Jerseys, Guernseys, Kerry and Dexter-Kerry.

The increased variety of sheep was also striking; Leicesters, Cotswolds, Lincolns, Oxford Downs, Shropshires, Southdowns, Hampshire Downs, Suffolks, Border Leicesters, Clun Forest, and Welsh Mountain.

Pigs were divided into Large, Middle, and Small white Berkshires, any other black breed, and Tamworths.

Altogether the total number of stock exhibited was $1,85^{8}$, and the number of implements was 5,430 .

In 1840 appeared Liebig's Chemistry in its Application to Agriculture and Physiology, tracing the relations between the nutrition of plants and the composition of the soil, a book which was received with enthusiasm, and completely changed the attitude which agriculturists generally had maintained towards chemistry; one of contempt, founded on ignorance.

But, as Mr. Prothero has said, ${ }^{2}$ 'if the new agriculture was born in the laboratory of Glissen, it grew into strength at the experimental station of Rothamsted.' There, for more than half a century, Lawes and Gilbert conducted experiments, of vast benefit to agriculture, in the objects, method, and effect of manuring; the scientific bases for the rotation of crops, and the results of various foods on animals in the production of meat, milk, and manure.

The use of artificial manures now spread rapidly; bones, used long before uncrushed, are said to have been first crushed in 1772 , and their value was realized by Coke of Holkham, but for long they were crushed by hammer or horse mill, and their use was consequently limited. Then iron rollers worked by steam ground them cheaply and effectively, and their use soon spread, though it was not till about 1840 that it can be said to have become general. Its effects were often described

1 At the show at Birmingham in 1898 there were 22 entries of Longhorns; in 1899 a Longhorn Cattle Society was established, and the herd. book resuscitated. More than twenty herds of the breed are now well established.

${ }^{2}$ R.A.S.E. Journal, 1901, p. 24 . 
as wonderful. In Cheshire, cheese-making had exhausted the soil, and it was said that by boning and draining an additional cow could be kept for every 4 acres, and tenants readily paid 7 per cent. to their landlords for expenditure in bone manure. Its use had indeed raised many struggling farmers to comparative independence. ${ }^{1}$ A very large quantity of the bones used came from South America. ${ }^{2}$ Porter also noticed that ' since 1840 an extensive trade has been carried on in an article called Guano', the guana of Davy, 'from the islands of the Pacific and off the coast of Africa'. Nitrate of soda was just coming in, but was not much used till some years later. In 1840 Liebig suggested the treatment of bones with sulphuric acid, and in 1843 Lawes patented the process and set up his works at Deptford. ${ }^{3}$

Italian rye grass, not to be confounded with the old English ray grass, had been introduced by Thomson of Banchory, in 1834 , from Munich $;^{4}$ and though the swede was known at the end of the eighteenth century, in many parts it had only just become common. In Notts it was in I844 described as having recently become 'the sheet-anchor of the farmer ${ }^{5}$. In Cheshire a writer at the same date said, ' in the year 1814 there were not 5 acres of Swedish turnips grown in the parish where I reside; now there are from 60 to 80 , and in many parts of the county the increase has been in a much greater ratio.' 6

About this time a remedy was found in the south for leaving the land idle during the nine months between harvesting the corn crop in August, and sowing the turnip crop in the following June, by sowing rye, which was eaten green by the sheep in May, a good preparation for the succeeding winter crop. Turnip cutters were at last being used, and corn and cake crushers soon followed.

1 Caird, English Agriculture in 1850-1, pp. 252 sq.

2 Porter, Progress of the Nation, p. I42.

3 R.A.S.E. Journal, I901, p. 25.

5 Ibid. (Ist ser.), vi. 2. 
The seasons from 1838 to $184 \mathrm{I}$ were bad, and must be characterized as a period of dearth, wheat keeping at. a good price. ${ }^{1}$ That of $1844-5$ was remarkable for the first general appearance of the potato disease, not only in these islands but on the continent of Europe. ${ }^{2}$ In August, 1846 , the worst apprehensions of the failure of the crop were more than realized, and the terrible results in Ireland are well known. In the early part of 1847 there was a fear of scarcity in corn, and the price of wheat rose to IO2s. $5 d$. in spite of an importation of $4,500,000$ quarters, but this was largely owing to the absence of any reliable agricultural statistics, which were not furnished till 1866 , and the price soon fell. ${ }^{3}$

We have now reached the period of free trade, when the Corn Laws, which had protected agriculture more or less effectually for so long, were definitely abandoned. That they had failed to prevent great fluctuations in the price of corn is abundantly evident, it is also equally evident that they kept up the average price; in the ten years from 1837 to 1846 , the average price of wheat was $58 s .7 d$. a quarter, in the seven years from 1848 to 1853 , the average price was $48 s .2 d .^{4}$ The average imports of wheat and flour for the same period were $2,161,813$ and $4,40 \mathrm{r}, 000$ quarters

1 1838, 64s. 7d.; 1839, 70s. 8d.; 1840, 66s. 4d.; 1841, 64s. 4d.

2 Tooke, History of Prices, iv. 19.

${ }^{3}$ C. Wren Hoskyns, Agricultural Statistics, p. 5.

- The abnormal prices during the Crimean War cannot fairly be taken into account. The home and foreign supplies of wheat and flour from 1839-46 were:-

$\begin{array}{lcc}\text { Home Supplies. } & \text { Foreign Supplies. } \\ \text { qrs. } & \text { qrs. } \\ 1839-40 & 4,022,000 & 1,762,482 \\ 1840-1 & 3,870,648 & 1,925,241 \\ 1841-2 & 3,626,173 & 2,985,422 \\ 1842-3 & 5,078,989 & 2,405,217 \\ 1843-4 & 5,213,454 & 1,606,912 \\ 1844-5 & 6,664,368 & 476,190 \\ 1845-6 & 5,699,969 & 2,732,134\end{array}$

Tooke, History of Prices, iv. 414 .

1844-5 was a very abundant crop, and the threatened repeal of the Corn Laws induced farmers to send all the corn possible to market. 
respectively. But to obtain the real effect of free trade on prices, the prices for the period between 1815 and 1846 must be compared with those between 1846 and the present day, when the fall is enormous.

The Act of 18 I 5 , which Tooke said had failed to secure any one of the objects aimed at by its promoters, had received two important alterations. In 1828 (9 Geo. IV, c. 60) a duty of $36 s .8 d$. was imposed when the price was $50 s$., decreasing to Is. when it was 73 s.

In 1842 (5 Vict. c. 14) a duty of 20 s. was imposed when the price was $5 \circ \mathrm{s}$, and the duty became $7 \mathrm{~s}$. when the price reached $65 s$.

A contemporary writer denies that these duties benefited the farmer at all: 'if the present shifting scale of duty was intended to protect the farmer, keep the prices of corn steady, insure a supply to the consumer at a moderate price, and benefit the revenue, it has signally failed. During the continuation of the Corn Laws the farmers have suffered the greatest privations. The variations in price have been extreme, and when a supply of foreign corn has been required it has only reached the consumer at a high price, and benefited the revenue little.' 1 Rents of farms were often calculated not on the market price of wheat, but on the price thought to be fixed by the duties, which was occasionally much higher. ${ }^{2}$

It was also said that but for the restrictions that had been imposed in the supposed interests of agriculture, the skill and enterprise of farmers would have been better directed than it had been. By means of these restrictions and the consequent enhancement of the cost of living, the cultivation of the land had been injuriously restricted, for the energies of farmers had been limited to producing certain descriptions of food, and they had neglected others which would have been 
far ${ }^{1}$ more profitable. The landlord had profited by higher rents, but, according to Caird, a most competent observer, had generally speaking been induced by a reliance on protection to neglect his duty to his estates, so that buildings were poor, and drainage neglected. The labourer was little if any better off than eighty years before. It was a mystery even to farmers how they lived in many parts of the country; 'our common drink', said one, 'is burnt crust tea, we never know what it is to get enough to eat.' ${ }^{2}$ Against these disadvantages can only be put the fact that protection had kept up the price of corn, a calamity for the mass of the people.

The amount of wheat imported into England before the era of Corn Law repeal was inconsiderable. Mr. Porter has shown ${ }^{3}$ how very small a proportion of wheat used in this country was imported from $1801-44$. From 1801 to 1810 the average annual import of wheat into the kingdom was 600,946 quarters, or a little over a peck annually per head, the average annual consumption per head being about eight bushels. Between I8II and 1820 the average importation was 458,578 quarters, or for the increased population a gallon-and-a-half per head, and the same share for each person was imported in the next decade $1821-30$. From $1831-40$ the average imports arose to 607,638 quarters, or two-and-a-quarter gallons per head, and in $184 I-4$ an average import of $I, 90 I, 495$ quarters raised the average supply to four-and-a-half gallons per person, still a very small proportion of the amount consumed.

In 1836 a small association had been formed in London for advocating the repeal of the Corn Laws, and in 1838 a similar association was formed in Manchester. ${ }^{4}$ At one

1 Tooke, History of Prices, iv. 142.

${ }^{2}$ From evidence collected by Mr. Austin in the southern counties.

3 Progress of Nation, pp. 137 sq. For the amount imported before that date, see Appendix 2.

- Walpole, History of England, iv. 63 sq. Cobden apparently never contemplated such low prices for corn as have prevailed since 1883 . In his speech of March 12, 1844, he mentioned 50s. a quarter as a probable price under free trade, and he died before the full effect of foreign competition was felt by the English farmer. 
of its earliest meetings appeared Richard Cobden, under whose guidance the association became the Anti-Corn Law League, and at whose invitation John Bright joined the League. Under these two men the Anti-Corn Law League commenced its great agitation, its object being 'to convince the manufacturer that the Corn Laws were interfering with the growth of trade, to persuade the people that they were raising the price of food, to teach the agriculturist that they had not even the solitary merit of securing a fixed price for corn'. The country was deluged with pamphlets, backed up by constant public meetings; and these efforts, aided by unfavourable seasons, convinced many of the errors of protection. In 1840 the League spent $£ 5,700$ in distributing 160,000 circulars and 150,000 pamphlets, and in delivering 400 lectures to 800,000 people. Bakers were persuaded to bake taxed and untaxed shilling loaves, and, on the purchaser choosing the larger, to demand the tax from the landlord; in 1843 the League collected $£ 50,000$, next year $£ 100,000$, and in $1845 £ 250,000$ in support of their agitation.

Yet for some years they had little success in Parliament; even in 1842 Peel only amended the laws; and it was not until I 846 that, convinced by the League's arguments, as he himself confessed, and stimulated by the famine in Ireland, he introduced the famous Act, 9 \& io Vict. c. 22.

By this the maximum duty on imported wheat was at once to be reduced to IOs. a quarter when the price was under $48 s$, to $5 s$. on barley when the price was under $26 s$, and to 4 s. on oats when the price was under $18 s$., with lower duties as prices rose above these figures, but the most important part of the Act was that on February I, I849, these duties were to cease, and only a nominal duty of Is. a quarter on foreign corn be retained, which was abolished in 1860 . ?

By 9 and ro Vict. c. 23 the duties on live stock were also, abolished entirely. Down to 1842 the importation of horned cattle, sheep, hogs, and other animals used as food was 
strictly prohibited, ${ }^{1}$ but in that year the prohibition was withdrawn and they were allowed to enter the country on a payment of $20 s$. a head on oxen and bulls, I5s. on cows, 35 . on sheep, $5^{s}$. on hogs; which duties continued till 1846 .

It is interesting to find that so shrewd an observer as McCulloch did not expect any great increase in the imports of live animals from the reduction of the duties, but he anticipated a great increase in salted meat from abroad; cold storage being then undreamt of.

The full effect of this momentous change was not to be felt for a generation, but the immediate effect was an agricultural panic apparently justified by falling prices. In $185^{\circ}$ wheat averaged $40 s .3 d$. and in $185^{1} 3^{8 s}$. $6 d$. On the other hand, stock farmers were doing well. But on the corn lands the prices of the protection era had to come down; many farms were thrown up, some arable turned into pasture; distress was widespread. Owing to the depressed state of agriculture in $185^{\circ}$, the Times sent James Caird on a tour through England, and one of the most important conclusions arrived at in his account of his tour is, that owing to protection, the majority of landowners had neglected their land; but another cause of neglect was that the great body of English landlords knew nothing of the management of their estates, and committed it to agents who knew little more and merely received the rents. The important business of being a landowner is the only one for which no special training is provided. Many of the landlords, however, then, as now, were unable to improve their estates if they desired to do so, as they were hopelessly encumbered, and the expense of sale was almost prohibitive. The contrast between good and bad farmers was more marked in $185^{\circ}$ than to-day, the efforts of the Royal Agricultural Society to raise the general standard of farming had not yet borne much fruit. In many counties, side by side, were farmers who used every modern improvement, and those 1 McCulloch, Commercial Dictionary, 1847, p. 274. See below, pp. 325 sq. 
who still employed the methods of the eighteenth century: on one farm wheat producing 40 bushels an acre, threshed by steam at a cost of $3 s .6 d$., on the next 20 bushels to the acre threshed by the flail at a cost of $9 s^{1}$

Drainage in the counties where it was needed had made considerable progress, the removal of useless hedgerows often crowded with timber, that kept the sun from the crops and whose roots absorbed much of the nourishment of the soil, was slowly extending, but farm-buildings almost everywhere were defective. 'The inconvenient ill-arranged hovels, the rickety wood and thatch barns and sheds devoid of every known improvement for economizing labour, food, and manure, which are to be met with in every county in England, are a reproach to the landlords in the eyes of all good farmers.' ${ }^{2}$ The farmbuildings of Belgium, Holland, France, and the Rhenish Provinces were much superior. In parts of England indeed no progress seems to have been made for generations at this date. Thousands of acres of peat moss in Lancashire were unreclaimed, and many parts of the Fylde district were difficult even to traverse. Even in Warwickshire, in the heart of England, between Knowle and Tamworth, instead of signs of industry and improvement were narrow winding lanes leading to nothing, traversed by lean pigs and rough cattle, broad copselike hedges, small and irregular fields of couch, amidst which straggled the stalks of some smothered cereal; these with gipsy encampments and the occasional sound of the poacher's gun from woods and thickets around were the characteristics of the district. ${ }^{3}$

Leases were the exception throughout England, though more prevalent in the west. 4 The greater proportion of farms were held on yearly agreements terminable by six months' notice on either side, a system preferred by the landlord as enabling him to retain a greater hold over his land, and

1 Caird, English Agriculture in 1850-1, p. 498. 2 Ibid, p. 490.

s Victoria County History: Warwickshire, ii. 277.

4 Caird, op. cit., p. 48r. 
acquiesced in by the tenant because of easy rents. In spite of this insecurity of tenure and the absence of Agricultural Holdings Acts, the tenants invested their capital largely with no other security than the landlord's character, 'for in no country of the world does the character of any class of men stand so high for fair and generous dealing as that of the great body of the English landlords.'

The custom of tenant-right was unknown except in certain f counties, Surrey, Sussex, the Weald of Kent, Lincoln, North Notts, and in part of the West Riding of Yorkshire. ${ }^{1}$ Where it existed, the agriculture was on the whole inferior to that of the districts where it did not, and it had frequently led to fraud in a greater or less degree. Many farmers were in the practice of 'working up to a quitting', or making a profit by the difference which their ingenuity and that of their valuer enabled them to demand at leaving as compared with what they paid on entry. The best farmers as well as the landlords were said to be disgusted with the system. The dislike for leases in the days immediately before the repeal of the Corn Laws was partly due to the uncertainty how long protection would last; but chiefly then, as afterwards, to the fact that if a man improved his farm under a lease he had nearly always to pay an increased rent on renewal, but if he held from year to year his improvement, if any, was so gradual and imperceptible that it was hardly noticed and the rent was not raised. It may also be attributable to the modern disinclination to be bound down to a particular spot for a long period. At all events, the general dislike of farmers for leases is a curious commentary on the assertions of those writers who said that leases were his chief necessity.

The disparity of the labourer's wages in $185^{\circ}$ was most remarkable, ranging from 15 s. a week in parts of Lancashire to $6 s$. in South Wilts, the average of the northern counties being I Is. $6 d$., and of the southern $8 s .5 d$. a difference due ${ }^{1}$ Caird, op. cit., p. $50 \%$. 
wholly to the influence of manufactures, which is still further proved by the fact that in Lancashire in 1770 wages were below the average for England. In fact since Young's time wages in the north had increased 66 per cent., in the south only 14 per cent. In Berkshire and Wiltshire there had been no increase in that period, and in Suffolk an actual decrease. It is not surprising to learn that in some southern counties wages were not sufficient for healthy sustenance, and the consequence was, that there, the average amount of poor relief per head of population was $8 s .8 \frac{1}{2} d$., but in the north $4 s .7 \frac{3}{4} d$., and the percentage of paupers was twice as great in the former as in the latter. This was mainly due to two causes: (I) the ratepayers of parishes in the south were accustomed to divide among themselves the surplus labour, not according to their requirements but in proportion to the size of their farms, so that a farmer who was a good economist of labour was reduced by this system to the same level as his unskilful neighbours, and the labourer himself had no motive to do his best, as every one, good and bad, was employed at the same rate. (2) To the system of close and open parishes, by which large proprietors could drive the labourer from the parish where he worked to live in some distant village in case he should become chargeable to the rates, so that it was a common thing to see labourers walking three or four miles each day to their work and back, and in one county farmers provided donkeys for them. Between 1840 and 1850 the labourer had, however, already benefited by free trade, for the price of many articles he consumed fell $30 \%$; on the other hand the rent of his cottage in eighty years had increased $100 \%$, and meat $70 \%$, which however did not, unfortunately, affect him much. The great development of railway construction also helped him by absorbing much surplus labour, and the work of his wife and children was more freely exploited at this date to swell the family budget. ${ }^{1}$

${ }^{1}$ Hasbach, op. cit., pp. 220, 226. 
The great difference between the wages of the north and the south is a clear proof that the wages of the agricultural labourer are not dependent on the prices of agricultural produce, for those were the same in both regions. It was unmistakably due to the greater demand for labour in the north.

The housing of the labourer was, especially in the south, often a black blot on English civilization. From many instances collected by an inquirer in 1844 the following may be taken. At Stourpaine in Dorset, one bedroom in a cottage contained three beds occupied by eleven people of all ages and both sexes, with no curtain or partition whatever. At Milton Abbas, on the average of the last census there were thirty-six persons in each house, and so crowded were they that cottagers with a desire for decency would combine and place all the males in one cottage, and all the females in another. But this was rare, and licentiousness and immorality of the worst kind were frequent. ${ }^{1}$

As for the farmer, the stock raiser was doing better than the corn grower. The following table shows the rent of cultivated land per acre, the produce of wheat per acre in bushels, the price of provisions, wages of labour, and rent of cottages in England at the date of Young's tours, about I 770 , and of Caird's in $1850:{ }^{2}$

Rent of cultivated land per acre.

1770

1850

1770

1850 13s. $4 d$.

26s. $10 d$.

Price of Wool per $1 b$. $5 \frac{1}{2} d$. Is.

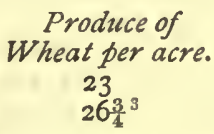

Cottage rents. 34s. $8 d$. $74 s .6 d$.

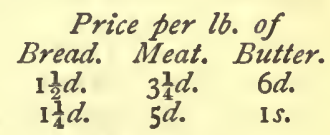

Labourer's wages per week.

$7 s .3 d$. 9s. $7 d$.

Thus in eighty years the average rent of arable land rose ,

1 Cobden's Speech, March 12, 1844.

2 Caird, English Farming, 1850-1, p. 474.

${ }^{3}$ Mr. Pusey, one of the best informed agriculturists of the day, estimated the produce of wheat per acre in 1840 at 26 bushels.-R.A.S. E. Journal, 1890, p. 20. 
$100 \%$, the average wheat crop $14 \%$, while the price of bread had decreased $16 \%$. But meat had increased $70 \%$, wool over $100 \%$, butter $100 \%$. The chief benefit to the farmer therefore lay in the increased value of live stock and its products, and it was found then, as in the present depression, that the holders of strong wheat land suffered most, which was further illustrated by the fact that the rent of the corngrowing counties of the east coast averaged 23s. $8 d$. per acre; that of the mixed corn and grass counties in the midlands and west, 3 Is. $5 d$.

Writing in 1847 , Porter said rents had doubled since 1790.1 In Essex farms could be pointed out which were let in 1790 at less than IOs. an acre, but during the war at from $45 \mathrm{~s}$. to $50 s$. In 1818 the rent went down to 35 s., and in 1847 wás $20 s$.

In Berks. and Wilts. farms let at 145 . per acre in 1790 , rose by 1810 to 70 s., or fivefold; sank in 1820 to 50 s.. and in 1847 to $30 s$. In Staffordshire farms on one estate let for $8 s$. an acre in 1790 , rose during the war to $35 s$., and at the peace were lowered to 20s., at which price they remained. Owing to better farming light soils had been applied to uses for which heavy lands alone had formerly been considered fit, with a considerable increase of rent.

On the Duke of Rutland's ${ }^{2}$ Belvoir estate, of from 18,000 to 20,000 acres of above average quality, rents were in-

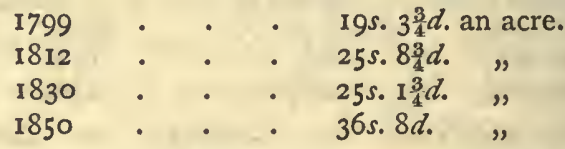

But the Dukes of Rutland were indulgent landlords and evidently took no undue advantage of the high prices during the war, a policy whose wisdom was fully justified afterwards.

It was the opinion of most competent judges, even after the abolition of the Corn Laws, that English land would continue

2 Thorold Rogers, History of Agriculture and Prices, v. 29. 
to rise in value. Porter stated that the United Kingdom could never be habitually dependent on the soil of other countries for the food of its people, there was not enough shipping to transport it if it could. ${ }^{1}$

Caird prophesied that in the next eighty years the value of land in England would more than double. The wellnigh universal opinion was that as the land of England could not increase, and the population was constantly increasing, land must become dearer. Men failed to foresee the opening of millions of acres of virgin soil in other parts of the world, and the improvement of transport to such an extent that wheat has occasionally been carried as ballast. About twentyfive or thirty years after these prophecies their fallacy began to be cruelly exposed. ${ }^{2}$

About $1853^{3}$ matters began to mend, chiefly owing to the great expansion in trade that followed the great gold discoveries in America and Australia. Then came the Crimean War, with the closing of the Baltic to the export of Russian corn, wheat in 1855 averaging $74 \mathrm{~s} .8 \mathrm{~d}$., and in the next decade the American War crippled another competitor, the imports of wheat from the United States sinking from $16,140,000 \mathrm{cwt}$. in 1862 to $635,000 \mathrm{cwt}$. in 1866 . From 1853 until 1875 English agriculture prospered exceedingly, assisted largely by good seasons. Between 1854 and 1865 there were ten good harvests, and only two below the average. Prices of produce rose almost continuously, and the price and rent of land with them. The trade of the country was good, and the demand for the farmer's products steadily grew; the capital value of the land, live stock, and crops upon it, increased in this period by $£ 445,000,000$. $^{4}$

1 Progress of the Nation, pp. 137-9.

2 Yet as the growth of population overtakes the corn and meat supply, these prophets may in the end prove correct.

3 The Great Exhibition of 1851 was said to have widely diffused the use of improved implements. -R.A.S.E. Journal, 1856, p. 54.

${ }^{4}$ R.A.S.E.Journal, 189o, p. 34. 
It appeared as if the abolition of the Corn Laws was not to have any great effect after all.

Now at last the great body of farmers began to approach the standard set them long before by the more energetic and enterprising. Early maturity in finishing live stock for the market by scientific feeding probably added a fourth to their weight. The produce of crops per acre grew, and drainage and improvements were carried out on all sides, the greatest improvement being. made in the cultivation and management of strong lands, of which drainage was the foundation, and enabled the occupier to add swedes to his course of cropping. ${ }^{1}$

It was in this period that Shorthorns, Herefords, and Devons attained a standard of excellence which has made them sought after by the whole world; and other breeds were perfected, the Sussex and Aberdeen Angus especially; while in sheep the improvement was perhaps even greater. ${ }^{2}$ The improved Lincolns, Oxford Downs, Hampshire Downs, and Shropshires took their place as standard breeds at this period. In I866, after many years of expectation and disappointment, agriculturists were furnished with statistics which are trustworthy for practical purpose, but are somewhat vitiated by the fact that the live stock census was taken on March 5: which obviously. omitted a large number of young stock; so that those for 1867 , when the census was taken on June 25 , are better for purposes of comparison with those of subsequent years, when the census has been taken on June 4 or 5 . Between . 1867. and 1878 the cattle in England and Wales had increased from $4,013,564$. to $4,642,641$, though sheep had diminished from $22,025,498$ to $21,369,810 .^{3}$. The total acreage under cultivation had increased from $25,451,526$ acres to $27,164,326$ acres in the same period.

There was, however, one black shadow in this fair picture:

${ }^{1}$ R.A.S.E.Journal, 1856, p.60. ${ }^{2}$ Ibid. 1901, p. 30. See below, p. 343.

3 Board of Agriculture Returns, 1878 , and R.A.S. E. Journal, I868, p. 239. Young estimated the number of cattle in England in 1770 at $2,852,048$, including 684,491 draught cattle.-Eastern Tour, iv. 456. 
in 1865 England was invaded by the rinderpest, which spread with alarming rapidity, killing 2,000 cows in a month from its first appearance, and within six months infecting thirty-six counties. ${ }^{1} \quad$ The alarm was general, and town and country meetings were held in the various districts where the disease appeared to concert measures of defence. The Privy Council issued an order empowering Justices to appoint inspectors authorized to seize and slaughter any animal labouring under such diseases; but, in spite of this, the plague raged with redoubled fury throughout September. There was gross mismanagement in combating it, for the inspectors were often ignorant men, and no compensation was paid for slaughter, so that farmers often sold off most of their diseased stock before hoisting the black flag. The ravages of the disease in the London cowhouses was fearful, as might be expected, and they are said to have been left empty; by no means an unmixed evil, as the keeping of cowhouses in towns was a glaring defiance of the most obvious sanitary laws. In October a Commission was appointed to investigate the origin and nature of the disease, and the first return showed a total of 17,673 animals attacked. By March 9, 1866, II7,664 animals had died from the plague, and 26,135 been killed in the attempt to stay it. By the end of August the disease had been brought within very narrow limits, and was eventually stamped out by the resolute slaughter of all infected animals. By November 24 the number of diseased animals that had died or been killed was $209,33^{2},{ }^{2}$ and the loss to the nation was reckoned at $£_{3}, 000,000$. The disease was brought by animals exported from Russia, who came from Revel, via the Baltic, to Hull. In 1872 , cattle brought to the same port infected the cattle of the East Riding of Yorkshire, but this outbreak was checked before much damage had been done, and since 1877 there has been no trace of this dreaded disease in the kingdom. The cattle plague,

${ }^{1}$ R.A.S.E. Journal (2nd ser.), ii. 230.

2 Ibid. iii. 430. 
rinderpest, or steppe murrain, is said ${ }^{1}$ to have first appeared in England in 1665 , the year of the Great Plague, and reappeared in 1714 , when it came from Holland, but did little damage, being chiefly confined to the neighbourhood of London. The next outbreak was in 1745, and lasted for twelve years, undoubtedly coming from Holland; it is said to have caused such destruction among the cattle, that much of the grass land in England was ploughed up and planted with corn, so that the exports of grain increased largely. In I769 it came again, but only affected a few localities, and disappeared in $177 \mathrm{I}$, not to return till 1865 .

Foot and mouth disease was first observed in England in $1839,{ }^{2}$ and it was malignant in $1840-1$, when cattle, sheep, and pigs were attacked as they were during the serious outbreak of $1871-2$. In 1883 no less than 219,289 cattle were attacked, besides 217,492 sheep, and $24,3.3^{2}$ pigs, when the disease was worse than it has ever been in England. Since then, though there have been occasional outbreaks, it has much abated. Another dread scourge of cattle, pleuro-pneumonia, was at its worst in 1872 , a most calamitous year in this respect, when 7,983 cattle were attacked. In 1890 the Board of Agriculture assumed powers with respect to it under the Diseases of Animals Act of that year, and their consequent action has been attended with great success in getting rid of the disease.

At the end of this halcyon period farmers had to contend with a new difficulty, the demand for higher wages by their labourers at the instigation of Joseph Arch. ${ }^{3}$ This famous agitator was born at Barford in Warwickshire in 1826 , and as a boy worked for neighbouring farmers, educating himself in his spare time. The miserable state of the labourer which he saw all around him entered into his soul, meat was rarely seen on his table, even bacon was a luxury in many cottages.

See Autobiography of Joseph Arch.

2 Ibid. ix. 274. 
Tea was $6 s$. to $7 s$. a lb., sugar $8 d$, and other prices in proportion; the labourers stole turnips for food, and every other man was a poacher. Arch made himself master of everything he undertook, became famous as a hedger, mower, and ploughman, and being consequently employed all over the Midlands and South Wales, began to gauge the discontent of the labourer who was then voiceless, voteless, and hopeless. His wages by 1872 had increased to $12 s$. a week, but had not kept pace with the rise in prices. Bread was $7 \frac{1}{2} d$. a loaf; the labourer had lost the benefit of his children's labour, for they had now all gone to school; his food was 'usually potatoes, dry bread, greens, herbs, "kettle broth" made by putting bread in the kettle, weak tea, bacon sometimes, fresh meat hardly ever' ${ }^{1}$. It is difficult to realize that at the end of the third quarter of the nineteenth century, when Gladstone said the prosperity of the country was advancing 'by leaps and bounds', that any class of the community in full work could live under such wretched conditions. Arch came to the conclusion that labour could only improve its position when organized, and the Agricultural Labourers' Union was initiated in 1872 . Not that the idea of obtaining better conditions by combination was new to the rural labourer. It was attempted in 1832 in Dorset, but speedily crushed, and not till 1865 was a new union founded in Scotland, which was followed by a strike in Buckinghamshire in 1867 , and the foundation of a union in Herefordshire in $1871 .{ }^{2}$ It was determined to ask for $16 s$. a week and a $9 \frac{1}{2}$ hours' working day, which the farmers refused to grant, and the men struck. The agitation spread all over England, and was often conducted unwisely and with a bitter spirit, but the labourer was embittered by generations of sordid misery. Very reluctantly, the farmers gave way, and generally speaking wages went up during the agitation to I4s. or I5s. a week, though Arch

1 In many districts, however, his food was better than this.

${ }^{2}$ Hasbach, op. cit., pp. 276-7. 
himself admits that even during the height of it they were often only IIs. and I2s. With the bad times, about 1879 , wages began to fall again, and men were leaving the Agricultural Union; by 1882 Arch says many were again taking what the farmer chose to give. From $\mathrm{I} 884$ the Union, steadily declined, and after a temporary revival about $\mathrm{x} 890$, practically collapsed in I 894 . Other unions had been started, but were then going down hill, and in 1906 only two remained in a moribund condition. Their main object, to raise the labourer's wages, was largely counteracted by the acute depression in agriculture, and though there has since been considerable recovery, there are districts in England to-day where he only gets i is. and I $2 s$. a week.

The Labourers' Union helped to deal a severe blow to the 'gang system', which had grown up at the beginning of the century (when the high corn prices led to the breaking up of land where there were no labourers, so that 'gangs' were collected to cultivate it ${ }^{1}$ ), by which overseers, often coarse bullies, employed and sweated gangs sometimes numbering 60 or 70 persons, including small children, and women, the latter frequently very bad specimens of their sex. These gangs went turnip-singling, bean-dropping, weeding, \&c., while pea-picking gangs ran to 400 or 500 . Though some of these gangs were properly managed, the system was a bad one, and the Union and the Education Acts helped its disappearance.

1 Hasbach, op. cit., pp. 193, et seq. The Gangs Act (30 \& 3 I Vict. c. I30) had already brought the system under control. 


\section{CHAPTER XXI}

$$
\text { 1875-1908 }
$$

AGRICULTURAL DISTRESS AGAIN.-FOREIGN COMPETITION.-AGRICULTURAL HOLDINGS ACTS.-NEW IMPLEMENTS.-AGRICULTURAL COMMISSIONS.THE SITUATION IN 1908

ABOUT the year 1875 the good times came to an end. The full force of free trade was at last felt. The seasons assisted the decline, and there was now no compensation in the shape of higher prices. In the eight years between 1874 and 1882 there were only two good crops. A new and formidable competitor had entered the field; between I860 and 1880 the produce of wheat in the United States had trebled. Vast stretches of virgin soil were opened up with the most astonishing rapidity by railroads, and European immigrants poured in. The cost of transport fell greatly, and England was flooded with foreign corn and meat. English land which had to support the landlord, the tithe-owner, the land agent, the farmer, the labourer, and a large army of paupers ${ }^{1}$, had to compete with land where often one man was owner, farmer, and labourer, with no tithe and no poor rates. Yet prices held up fairly well until 1884 , when there was a collapse from which they have not yet recovered. In 1877 wheat was $56 s .9 d$., in $188341 s$. $7 d$., and in 188435 s. $8 d$.; by 1894 the average price for the year was $22 s$. $10 d .^{2}$

Farmers' capital was reduced from 30 to 50 per cent., and rents and the purchase value of land in a similar proportion. Poor clays only fit for wheat and beans went out of cultivation, though much has since been laid down to grass, and much has 'tumbled down'. In fact most of the increased value of the good period between $1853-75$ disappeared.

${ }^{1}$ And an ever increasing burden of taxation.

${ }^{2}$ See Appendix III. 
The year 1879 will long be remembered as 'the Black Year'. It was the worst of a succession of wet seasons in the midland, western and southern counties of England, the average rainfall being one-fourth above the average, and $\mathrm{I} 880$ was little better. The land, saturated and chilled, produced coarser herbage, the finer grasses languished or were destroyed, fodder and grain were imperfectly matured. Mould and ergot were prevalent among plants, and flukes producing liver-rot among live stock, especially sheep. In 1879 in England and Wales $3,000,000$ sheep died or were sacrificed from rot, ${ }^{1}$ by $18815,000,000$ had perished at an estimated loss of EI $0,000,000$, and many, alas! were sent to market full of disease. Cattle also were infected, and hares, rabbits, and deer suffered. In some cases entire flocks of sheep disappeared. The disease was naturally worst on low-lying and ill-drained pastures, but occurred even on the drier uplands hitherto perfectly free from liver-rot, carried thither no doubt by the droppings of infected sheep, hares, and rabbits, and perhaps by the feet of men and animals. Apart from medicine, concentrated dry food given systematically, the regular use of common salt, and of course removal from low-lying and damp lands, were found the best preventives.

Besides this great calamity, this year was distinguished by one of the worst harvests of the century, outbreaks of foot and mouth disease, of pleuro-pneumonia, and a disastrous attack of foot-rot. The misfortunes of the landed interest produced a Commission in 1879 under the Duke of Richmond, which conducted a most laborious and comprehensive inquiry. Their report, issued in 1882 , stated that they were unanimously convinced of the great intensity and extent of the distress that had fallen upon the agricultural community. Owner and occupier had alike been involved. Yet, though agricultural distress had prevailed over the whole country, the degree had varied in different counties, and in some cases in different 
parts of the same counties. Cheshire, for instance, had not suffered to anything like the same extent as other counties, nor was the depression so severe in Cumberland, Westmoreland, Northumberland, and parts of Yorkshire. The rainfall had been less in the northern counties. In the midlands, the eastern, and most of the southern counties the distress was severe, in Essex the state of agriculture was deplorable, but Kent, Devon, and Cornwall were not hardly hit. ${ }^{1}$

The chief causes of the depression were said to be these :-

I. The succession of unfavourable seasons, causing crops deficient in quantity and quality, and losses of live stock.

2. Low prices, partly due to foreign imports and partly to the inferior quality of the home production.

3. Increased cost of production.

4. Increased pressure of local taxation by the imposition of new rates, viz. the education rate and the sanitary rate; and the increase of old rates, especially the highway rate, in consequence of the abolition of turnpikes. Some exceptionally bad instances of this were given. In the parish of Didmarton, Gloucestershire, the average amount of rates paid for the five years ending March 31, 1858, was $£ 266 s$. $3 d$., for the five years ending March $31,1878, £$ II 8 IIs. $7 d$. In the Northleach Union the rates had increased thus in decennial periods from 1850 :-

$\begin{array}{rccccr}1850-1 & \cdot & \cdot & \cdot & \cdot & £ 5,471 \\ 1860-1 & \cdot & \cdot & \cdot & \cdot & 5,534 \\ 1870-1 & \cdot & \cdot & \cdot & \cdot & 8,525 \\ 1878-9 & \cdot & \cdot & \cdot & \cdot & 10,089\end{array}$

On one small property in Staffordshire the increase of rates, other than poor rates, amounted to $3 s .6 d$. in the $£$ on the rateable value.

5. Excessive rates charged by railway companies for the conveyance of produce, and preferential rates given to foreign agricultural produce; the railway companies alleging, in defence

${ }_{1}$ Parliamentary Reports of Commissioners, 1882, xiv. pp. 9 sq. 
of this, that foreign produce was consigned in much greater bulk, by few consignors, than home grown, and could be conveyed much more economically than if picked up at different stations in small quantities.

As to the effect of restrictive covenants on the depression, the balance of evidence did not incline either way. ${ }^{1}$

The Agricultural Holdings Act of 1875 was stated to have done much good in the matter of compensation to tenants for improvements, notwithstanding its merely permissive character, as it had reversed the presumption of law in relation to improvements effected by the tenant, prescribed the amount of compensation, and the mode in which it should be given.

As to the important subject of freedom of cropping and sale of produce, there were diverse opinions, some advocating it wholly, others not believing in it at all, others saying each landlord and each tenant should make their own bargains since each farm stands on its own footing, others again favouring modified restrictions. The preponderance of opinion was in favour of a modification of the law of distress.

The Commission further said that the pressure of foreign competition was greatly in excess of the anticipations of the supporters and of the apprehensions of the opponents of Corn Law Repeal; if it had not been for this, English farmers would have been partly compensated for the deficient yield by higher prices. On the other hand, the farmer had had the advantage of an increased and cheapened supply of feeding stuffs, such as maize, linseed and cotton cakes, and of artificial manures imported from abroad. At the same time the benefit to the community from cheap food was immense. It seemed just, however, that as agriculture was suffering from low prices, by which the country gained as a whole, that the proportion of taxation imposed on the land should be lessened; it was especially unjust that personal property was exempted from local rates, contrary to the Act of 43 Eliz.c. 2, and the whole

1 Parliamentary Reports of Commissioners, 1882, xiv. I4. 
burden thrown on real property. The difficulties of farmers were aggravated by the high price of labour, which had increased 25 per cent. in twenty years, largely owing to the competition of other industries, and at the same time become less efficient. As provisions were cheap, and employment abundant, the labourer had been scarcely affected by the distress. His cottage, however, especially if in the hands of a small owner, with neither the means nor the will to expend money on improvements, was often still very defective.

Farmers were already complaining of the results of the new system of education, for which they had to pay, while it deprived them of the labour of boys, and drained from the land the sources of future labour by making the young discontented with farm work. The Commission denied that rents had been unduly raised previous to $1875^{1}$; and in the exceptional cases where they had been, it was due to the imprudent competition of tenant farmers encouraged by advances made by country bankers, the sudden withdrawal of which had greatly contributed to the present distress. Districts where dairying was carried on had suffered least, yet the yield of milk was much diminished, and the quality deteriorated, owing to the inferiority of grass from a continuance of wet seasons. The production and sale of milk was increasing largely, so that the attention of farmers and landlords was being drawn to this important branch of farming, milk-sellers necessarily suffering less from foreign competition than any other farmers.

Let us turn once more to the hop yards: in 1878 the acreage of hops in England reached its maximum. We have seen that in the first half of the eighteenth century hop yards covered 12,000 acres; which between 1750 and 1780 increased to 25,000 , and by 1800 to 32,000 . In $1878,71,789$ acres were grown. The great increase prior to that year was due to the abolition of the excise duty in 1862 , which on an average

1 The rise between 1857 and 1878 has been estimated at 20 per cent., and between 1867 and 1877 at $11 \frac{1}{2}$ per cent., Hasbach, op. cit., p. 291. 
was equal to an annual charge of nearly $£ 7$ an acre. ${ }^{1}$ This encouraged hop-growing more than the taking off of the import duty in the same year discouraged it. In 1882 there was a very small crop in England, which raised the average price to $£$ I 8 Ios. a cwt.; some choice samples fetching $£ 30$ a cwt.; growers who had good crops realizing much more than the freehold value of the hop yards. This, however, was most unfortunate for them, as it led to a great increase in the use of hop substitutes, such as quassia, chiretta, colombo, gentian, \&c., which, with the decreasing consumption of beer and the demand for lighter beer, has done more than foreign competition to lower the price and thereby cause so large an area to be grubbed up as unprofitable, that in 1907 it was reduced to $44,93^{8}$ acres. Yet the quality of the hops has in the last generation greatly improved in condition, quality, and appearance. Growers also have in the same period often incurred great expense in substituting various methods of wire-work for poles; and washing, generally with quassia chips and soft soap and water, has become wellnigh universal, so that the expense of growing the crop has increased, while the price has been falling. ${ }^{2}$ The crop has always been an expensive one to grow; Marshall in $\mathbf{I} 798$ put it at $£ 20$ an acre, exclusive of picking, drying, and marketing; ${ }^{3}$ and Young estimated the total cost at the same date at $£_{3} I$ Ios. an acre; ${ }^{4}$ to-day $£ 40$ an acre is by no means an outside price. It may be some encouragement to growers to remember that hops have always been subject to great fluctuations in price; between 1692 and $I 700$, for instance, they varied from 40 s. to 240 s. a cwt., so that they may yet see them at a remunerative figure. 'Upon the whole', says an eighteenth-century writer, 'though many have acquired large estates by hops, their real advantage is perhaps questionable. By engrossing the

1 R.A.S.E. Journal, 189o, p. 324.

3ural Economy of Southern Counties, i. 285-6.

2 See infra, p. 330.

4 Victoria County History: Hereford, Agriculture. 
attention of the farmer they withdraw him from slower and more certain sources of wealth, and encourage him to rely too much upon chance for his rent, rather than the honest labour of the plough. To the landlord the cultivation of hops is an evil, defrauding the arable land of its proper quantity of manure and thereby impoverishing his estate.'

It was by this time the general opinion of men with a thorough experience of farming, that in many parts of Great Britain no sufficient compensation was secured to the tenant for his unexhausted improvements. In some counties and districts this compensation was given by established customs, in others customs existed which were insufficient, in many they did not exist at all. It must be confessed that often when a tenant leaves his farm there is more compensation due to the landlord than to the tenant. Human nature being what it is, the temptation to get as much out of the land just before leaving it is wellnigh irresistible to many farmers.

In these days, when the landlord is often called upon by the tenant to do what the tenant used to do himself, the question of compensation to the tenant must on many estates appear to the landlord extremely ironical. It is, in the greater number of cases, the landlord who should receive compensation, and not the tenant; and though he has power to demand it, such power is over and over again not put in force.

At the same time there are bad men in the landlord class as in any other, and from them the tenant required protection. By the Agricultural Holdings (England) Act of $1875,38 \& 39$ Vict. c. 92, improvements for which compensation could be claimed by the tenant were divided into three classes. First class improvements, such as drainage of land, erection or enlargement of buildings, laying down of permanent pasture, $\& c$., required the previous consent in writing of the landlord to entitle the tenant to compensation. Second class improvements, such as boning of land with undissolved bones, chalking, 
claying, liming, and marling the land, the latter now hardly ever practised, required notice in writing by the tenant to the landlord of his intention, and if notice to quit had been given or received, the consent in writing of the landlord was necessary. For third class improvements, such as the application to the land of purchased manure, and consumption on the holding by cattle, sheep, or pigs, of cake or other feeding stuff not produced on the holding, no consent or notice was required. Improvements in the first class were deemed to be exhausted in twenty years, in the second in seven, and in the third in two. It was the opinion of the Richmond Commission of I 879 that, notwithstanding the beneficial effects of this Act, no sufficient compensation for his unexhausted improvements was secured to the tenant.

The landlord and tenant also might agree in writing that the Act should not apply to their contract of tenancy, so in I 883 when the Agricultural Holdings Act of that year ( 46 \& 47 Vict. c. $61^{1}$ ) was passed, it was made compulsory as far as regarded compensation, and the time limit as regards the tenant's claims for improvements was abolished, the basis for compensation for all improvements recognized by the Act being laid down as 'the value of the improvement to an incoming tenant'. Improvements for which compensation could be claimed were again divided into three classes as before, but the drainage of land was placed in the second class instead of the first, and so only required notice to the landlord. This was the only improvement in the second class; the other improvements which had been in the second class in the Act of 1875 were now placed in the third, where no consent or notice was required.

1 In one respect the Act of 1883 restricted the rights of tenants to compensation, for while the Act of 1875 had expressly reserved the rights of the parties under 'custom of the country', the Act of 1883 provided that a tenant "shail not claim compensation by custom or otherwise than in manner authorized by this Act for any improvement for which he is entitled to compensation under this Act' $(\$ 57)$. 
The Act also effected three other important alterations in the law ; first, as to 'Notices to Quit', a year's notice being necessary where half a year's notice had been sufficient, though this section might be excluded by agreement; secondly, after January 1,1885 , the landlord could only distrain for one year's rent instead of six years as formerly; and thirdly, as to fixtures. These formerly became the property of the landlord on the determination of the tenancy, but by $I_{4} \& I_{5}$ Vict. c. 25 an agricultural tenant was enabled to remove fixtures put up by him with the consent of his landlord for agricultural purposes. Now all fixtures erected after the commencement of the Act were the property of and removable by the tenant, but the landlord might elect to purchase them.

This Act was amended by the Act of 1900 ( 63 \& 64 Vict. c. 50), and has been much altered by the Agricultural Holdings Act of 1906 (6 Edw. VII, c. 56), which has treated the landlord with a degree of severity, which considering the excellent relations that have for the most part existed between English landlords and tenants for generations, is utterly unwarranted. In several respects indeed he has been treated by the Act as if the land did not belong to him, while freedom of contract, until recent years one of the most cherished principles of our law, is arbitrarily interfered with. The chief alterations made by the Act of 1906 were :-

r. Improvements.-By the Act of $\mathrm{I}_{88}$, in the valuation for improvements under the first schedule, such part of the improvement as is justly due to the inherent capabilities of the soil was not credited to the tenant. This provision is repealed by the Act of 1906 , in reference to which it must be said that the latent fertility of the soil, sometimes very considerable may be developed by a small outlay on the part of the tenant for which outlay he is certainly entitled to compensation. But the greater part of the improvement may be due to the soil which belongs to the landlord, yet the Act credits the 
tenant with the whole of this improvement. An addition is made to the list of improvements which a tenant may make without his landlord's consent and for which he is entitled on quitting to compensation, viz. repairs to buildings, being buildings necessary for the proper working of the holding, other than repairs which the tenant is obliged to execute.

2. Damage by Game. A tenant may now claim compensation for damage to crops by deer, pheasants, partridges, grouse, and black game.

3. Freedom of Cropping and Disposal of Produce. Prior to this Act it had been the custom for generations to insert covenants in agreements providing for the proper cultivation of the farm; as, for instance, forbidding the removal from the holding of hay, straw, roots, green crops, and manure made on the farm. These and other covenants were merely in the interests of good farming, and to prevent the soil deteriorating. In recent times vexatious covenants formerly inserted had practically disappeared, and where still existing were seldom enforced. By this Act, notwithstanding any custom of the country or any contract or agreement, the tenant may follow any system of cropping, and dispose of any of his produce as he pleases, but after so doing he must make suitable and adequate provision to protect the farm from injury thereby: a proviso vague and difficult to enforce, and not sufficient to prevent an unscrupulous tenant greatly injuring his farm.

4. Compensation for unreasonable disturbance. If a landlord without good cause, and for reasons inconsistent with good estate management, terminates a tenancy by notice to quit; or refuses to grant a renewal of the tenancy if so requested at least one year before the expiration thereof; or if a tenant quits his holding in consequence of a demand by the landlord for an increased rent, such demand being due to an increased value in the holding owing to improvements done by. 
the tenant; in either of such events the tenant is entitled to compensation.

This compensation for disturbance is in direct opposition to the recommendation of the Commission of $1894,{ }^{1}$ and seems to be an unwarrantable interference with the owner's management of his own land.

Another benefit, and one long needed, was conferred on farmers by the Ground Game Act of 1880,43 \& 44 Vict., c. 47. Before the Act the tenant had by common law the exclusive right to the game, including hares and rabbits, unless it was reserved to the landlord, which was usually the case. By this Act the right to kill ground game, which often worked terrible havoc in the tenant's crops, was rendered inseparable from the occupation of the land, though the owner may reserve to himself a concurrent right. One consequence of this Act has been that the hare has disappeared from many parts of England.

The greatest improvement in implements during this period was in the direction of reaping and mowing machines, which have now attained a high degree of perfection. As early as I 780 the Society of Arts offered a gold medal for a reaping machine, but it was not till 1812 that John Common of Denwick, Northumberland, invented a machine which embodied all the essential principles of the modern reaper. Popular hostility to the machine was so great that Common made his early trials by moonlight, and he ceased from working on them. ${ }^{2}$ His machine was improved by the Browns of Alnwick, who sold some numbers in 1822 , and shortly afterwards emigrated to Canada taking with them models of Common's reapers. $\mathrm{M}^{\mathrm{c}}$ Cormick, the reputed inventor of the reaping machine, knew the Browns, and obtained from them a model of Common's machine which was almost certainly the father of the famous machine exhibited by him at the Great

1 Parliamentary Reports, Commissioners (1897), xv. 96.

${ }^{2}$ R. A.'S. E. Journal (1892), p. 63. 
Exhibition of $185 \mathrm{I}$. Various other inventors have assisted in improving this implement, and in 1873 the first wire binder was exhibited in Europe by the American, W. A. Wood, wire soon giving place to string owing to the outcry of farmers and millers. The self-binding reaper is the most ingenious of agricultural machines, and has been of enormous benefit to farmers in saving labour. Though the hay-tedding machine was invented in $\mathrm{I}_{8} \mathrm{I}_{4}$ it is only during the last thirty years that its use has become common, the spread of the mowing machine making it a necessity, cutting the grass so fast that only a very large number of men with the old forks could keep up with it. The tedder also rendered raking by hand too slow, and the horse-rake, patented first in r84I, has immensely improved in the last thirty years.

Another enormous labour saver is the hay and straw elevator, having endless chains furnished with carrying forks at intervals of a few feet, driven by horse gear. The steam cultivator invented by John Fowler is much used, but cannot be said to have superseded the ordinary working stock of the farm, though for deep ploughing on large farms of heavy land it is invaluable. Improvements in dairying appliances have also been great, but the English farmer has generally fought shy of factories or creameries, so that his butter still lacks the uniform quality of his foreign rivals.

In manures the most important innovation in the last generation has been the constantly growing use of basic slag, formerly left neglected at the pit mouth and now generally recognized as a wonderful producer of clover.

Most of the suggestions of the Commission of 1879 were carried into effect. Rents were largely reduced, so that between 1880 and 1884 the annual value of agricultural land in England sank $£ 5,750,0000^{1}$ Grants were made by the Government in aid of local burdens, cottages were improved although the landowners' capital was constantly dwindling,

${ }^{1}$ R. A.S.E. Journal (1901), p. 33. Cf. infra, p. 310. 
Settled Land Acts assisted the transfer of limited estates, a Minister of Agriculture was appointed in $\mathrm{x} 889$, and in $18 \mathrm{~g}$ the payment of the tithe was transferred from the tenant to the landlord, which generally meant that the whole burden was now borne by the latter.

Still foreign imports continued to pour in and prices to fall. Wheat land, which was subject to the fiercest competition, began to be converted to other uses, and between 1878 and 1907 had fallen in England from 3,04I,2I4 acres to $1,537,208$, most of it being converted to pasture or 'tumbling down' to grass, while a large quantity was used for oats. The price of live stock was now falling greatly before increasing imports of live animals and dead meat, while cheese, butter, wool, and fruit were also pouring in. Farming, too, was now suffering from a new enemy, gambling in farm produce, which began to show itself about $I 880$ and has since materially contributed to lowering prices. ${ }^{1}$ The enormous gold premium in the Argentine Republic, with the steady fall in silver, was another factor. As Mr. Prothero says, 'Enterprise gradually weakened, landlords lost their ability to help, and farmers their recuperative power. The capital both of landlords and tenants was so reduced that neither could afford to spend an unnecessary penny. Land deteriorated in condition, drainage was practically discontinued ... less cake and less manure were bought, labour bills were reduced, and the number of males employed in farming dwindled as the wheat area contracted.' ${ }^{2}$ The year 1893 was remarkable for a prolonged drought in the spring; from March 2 to May I4 hardly any rain fell, and live stock were much reduced in quality from the parching of the herbage, while in many parts the difficulty of supplying them with water was immense.

In the same year another Commission on Agriculture was appointed, whose description of the condition of agriculture

1 R. A. S. E. Journal (1893), p. 286; (1894), p. 677. Sometimes to artificially raising them.

Ibid. (Igor), p. 34 . 
was a lamentable one. The Commission in their final report ${ }^{1}$ stated that the seasons since 1882 had on the whole been satisfactory from an agricultural point of view, and the evidence brought forward showed that the existing depression was to be mainly attributed to the fall in prices of farm produce. This fall had been most marked in the case of grain, particularly wheat, and wool also had fallen heavily. It was not surprising therefore to find that the arable counties ${ }^{2}$ had suffered most; in counties where dairying, market gardening, poultry farming, and other special industries prevailed the distress was less acute, but no part of the country could be said to have escaped. In north Devon, noted for stock rearing, rents had only fallen Io to 15 per cent. since $188 \mathrm{r}$, and in many cases there had been no reduction at all. In Herefordshire and Worcestershire good grass lands, hop lands, and dairy farms had maintained their rents in many instances, and the reductions had apparently seldom exceeded I5 per cent.; on the heavy arable lands, however, the reduction was from 20 to 40 per cent.

In Cheshire, devoted mainly to dairying, there had been no general reduction of rent, though there had been remissions, and in some cases reductions, of ro per cent.

In fact, grazing and dairy lands, which comprise so large an area of the northern and western counties, were not badly affected, though the depreciation in the value of live stock and the fall in wool had considerably diminished farm profits and rents. But of the eastern counties, those in which there are still large quantities of arable land, a different tale was told. In Essex much of the clay land was going out of cultiva-

1 Parliamentary Reports, Commissioners (I 897), xv.

2 Broadly speaking, the arable section, or eastern group, included the counties of Bedford, Berks., Bucks, Cambridge, Essex, Hants, Hertford, Huntingdon, Kent, Leicester, Lincoln, Middlesex, Norfolk, Northampton, Notts, Oxford, Rutland, Suffolk, Surrey, Sussex, Warwick, and the East Riding of York; the grass section, or western group, included the remaining counties. 
tion; many farms, after lying derelict for a few years, were let as grass runs for stock at a nominal rent. The rent of an estate near Chelmsford of $1,4 \mathrm{I} 8$ acres had fallen from $£ \mathrm{I}, 3 \mathrm{I} 4$ in 1879 to $£ 415$ in 1892 , or from $18 s$. $6 d$. an acre to $5 s$. Iod. ${ }^{1}$ The net rental of another had fallen from $£ 7,682$ in $188 \mathrm{r}$ to $£ 2,224$ in 1892 , and the landlord's income from his estate of 13,009 acres in $1892-3$ was Is. an acre. The balance sheet of the estate for the same year is an eloquent example of the landowner's profits in these depressed times : ?

RECEIPTS.

Tithe received $\quad 798 \quad 5 \quad 9$

Cottage rents . . 49586

Garden " . . 213510

Estate " . . 7,452 $14 \quad 8$

Tithes refunded by

tenants

$$
530 \quad 15 \quad 2
$$

\section{$\$ 9,490 \quad 9$ II}

PAyMenTS.

Tithe, rates, and taxes 2,964 I 9 Rent-charge and fee

farm rents . . $179 \circ 4$

Gates and fencing . $\quad 878$

Estate repairs and

buildings

- 4,350128

Draining . . . 17061

Brickyard. . $\quad \begin{array}{llll}170 & 1 & 8\end{array}$

Management . . 936147

Insurances - . 58115

Balance profit . 652139

$£ 9,490 \quad 911$

In the great agricultural county of Lincoln rents had fallen from 30 to 75 per cent. ${ }^{3}$ The average amount realized on an acre of wheat had fallen from $£$ Io $6 s .3 d$. in $1873-7$ to $£^{2} I 8 s$. II $d$. in $1892^{4}$; and the fall in the price of cattle between 1882 and 1893 was a little over 30 per cent. Many of the large farmers in Lincolnshire before 1875 had lived in considerable comfort and even luxury, as became men who had invested large sums, sometimes $£ 20,000$, in their business. They had carriages, hunters, and servants, and gave their children an excellent start in life. But all this was changed; a day's hunting

1 Parliamentary Reports, Commissioners (1894), xvi (1), App. B. ii.

2 Ibid. App. B. iii.

3 Ibid. (1895), xvi. I69.

4 Ibid. p. 164. 
occasionally was the utmost they could afford, and wives and daughters took the work from the servants. The small farmers had suffered more than the large ones, and the condition of the small freeholders was said to be deplorable; a fact to be noted by those who think small holdings a panacea for distress. ${ }^{1}$

Even near Boston, where the soil is favourable for market gardening, the evidence of the small holder was 'singularly unanimous' as to their unfortunate condition. The small occupiers were better off than the freeholders, because their rents had been reduced and they could leave their farms if they did not pay; but their position was very unsatisfactory. From the evidence given to the assistant commissioner it is clear that the small occupier and freeholder could only get on by working harder and living harder than the labourer. 'We all live hard and never see fresh meat,' said one. 'We can't afford butcher's meat,' said another. Another said, 'In the summer I work from 4 a.m. to 8 p.m., and often do not take more than an hour off for meals. That is penal servitude, except you have your liberty. A foreman who earns $£ 1$ a week is better off than I am. He has no anxiety, and not half the work.' These instances could be multiplied many times, so that it is not surprising that the children of these men have flocked to the towns.

In Norfolk, 'twenty or thirty years ago, no class connected with the land held their heads higher' than the farmers. Many of them owned the whole or a part of the land they farmed, and lived in good style. All this was now largely changed. 'The typical Norfolk farmer of to-day is a harassed and hardworking man,' engaged in the struggle to make both ends meet. Many were ruined.

However, there were farmers who, by skill, enterprise, and careful management, made their business pay even in these times, such as the tenant of the farm at Papplewick in Nottinghamshire who gained the first prize in the Royal Agricultural

1 Parliamentary Reports, Commissioners (1895), xvi. 187-8. 
Society's farm competition in $1888 .{ }^{1}$ This farm consisted of 522 acres, of which only $6 \mathrm{I}$ were grass, but chiefly owing to the trouble taken in growing fine root crops, a large number of live stock were annually purchased-and sold off, the following balance sheet showing a profit of $£ 3$ Is. od. per acre :

\begin{tabular}{|c|c|c|}
\hline $\begin{array}{l}\text { DR. } \\
\text { Rent, tithes, rates, taxes, \&c. } \\
\text { Wages . . . } \\
\text { Purchase of cake, corn, } \\
\text { seeds, manure, \&c. . } \\
\text { Purchase of live stock. }\end{array}$ & $\begin{array}{r}\qquad \\
278 \\
387 \\
\\
688 \\
2,654\end{array}$ & $\begin{array}{l}\text { CR. } \\
\text { Corn, hay, potatoes, and } \\
\text { like produce sold } \\
\text { Live stock, poultry, dairy } \\
\text { produce, and wool sold }\end{array}$ \\
\hline Profit & $\begin{array}{r}64,007 \\
1,589\end{array}$ & \\
\hline & $£ 5,596$ & \\
\hline
\end{tabular}

The reductions of rents in various counties were estimated thus ${ }^{2}$ :

\begin{tabular}{|c|c|c|c|c|c|c|}
\hline & & Percent. & & & & Per cent. \\
\hline Northumberlai & and & - 20 to 25 & Hereford & & • & - 20 to 30 \\
\hline Cumberland & & - 30 to 40 & Somerset & & , & - 20 to 40 \\
\hline York & • & . 10 to 50 & Oxford & • & - & - 25 to 50 \\
\hline Lancaster & - & 5 to 30 & Suffolk & . & - & - up to 70 \\
\hline Stafford . & & - Io to 25 & Essex & - & - & - 25 to 100 \\
\hline Leicester . & ${ }^{\circ}$ & 40 & Kent & - & • & - 15 to $1 \mathrm{co}$ \\
\hline Nottingham & . & - 14 to 50 & Hants & . & . & - 25 to 100 \\
\hline Warwick. & - & - 25 to 60 & Wilts. & - & - & . 10 to 75 \\
\hline Huntingdon & $\cdot$ & - 40 to 50 & Devon & & • & - 10 to 25 \\
\hline Derby & - & - 14 to 25 & Cornwall & & • & - Io to 100 \\
\hline
\end{tabular}

This large reduction in the rent rolls of landowners has materially affected their position and weakened their power. Many, indeed, have been driven from their estates, while others can only live on them by letting the mansion house and the shooting, and occupying some small house on the lands they are reluctant to leave. The agricultural depression, which set

\footnotetext{
1 R. A. S. E. Journal (2nd ser.), xxiv. 538.

2 Ibid. (1894), p. 681.
} 
in about 1875 , may in short be said to have effected a minor social revolution, and to have completed the ruin of the old landed aristocracy as a class. The depreciation of their rents may be judged from the following figures ${ }^{1}$ :

Gross annual value of lands, including tithes, under Schedule $A$ in England.

$1879-80$

Ł

$48,533,340$
1893-4

$\underset{36,999,846}{£}$
Decrease. Amount. Per cent. $£$

I I 533,494

These figures, however, are far from indicating the full extent of the decline in the rental value of purely agricultural land, as they include ornamental grounds, gardens, and other properties, and do not take into account temporary remissions of rent. Sir James Caird, as early as I 886 , estimated the average reduction on agricultural rents at 30 per cent.

The loss in the capital value of land has inevitably been, great from this reduction in rents, and has been aggravated by the fact that the confidence of the public in agricultural land as an investment has been much shaken. In 1875 thirty years' purchase on the gross annual value of land was the capital value, in 1894 only eighteen years' purchase; and whereas the capital value of land in the United Kingdom was in 1875 $£ 2,007,330,000$, in 1894 it was $£ \mathrm{I}, 001,829,212$, a decrease of 49.6 per cent. Moreover, landlords have incurred increased expenditure on repairs, drainage, and buildings, and taxation has grown enormously. On the occupiers of land the effect of the depression was no less serious, their profits having fallen on an average 40 per cent. $^{2}$ Occupying owners had suffered as much as any other class, both yeomen who farmed considerable farms and small freeholders. Many of the former had bought land in the good times when land was dear and left a large portion of the purchase money on mortgage, with the

1 Parliamentary Reports, Commissioners (1897), xv. 22. Cf. p. 319 n.

2 Ibid. pp. 30-1. 
result that the interest on the mortgage was now more than the rent of the land. ${ }^{1}$

They were thus worse off than the tenant farmer, for they paid a higher rent in the shape of interest; moreover, they could not leave their land, for it could only be sold at a ruinous loss. The 'statesmen' of Cumberland were weighed down by the same burdens and their disappearance furthered; for instance, in the parish of Abbey Quarter, between 1780 and 1812 their number decreased from $5 \mathrm{I}$ to 38 . By 1837 it was 30 ; by 1864,21 ; and in 1894 only 9 remained.

The small freeholders were also largely burdened with mortgages, and even in the Isle of Axholme were said to have suffered more than any other class; largely because of their passion for acquiring land at high prices, leaving most of the purchase money on mortgage, and starting with insufficient capital.

As regards the agricultural labourer, ${ }^{2}$ the chief effect of the depression had been a reduction of the number employed and a consequent. decrease in the regularity of employment. Their material condition had everywhere improved, ${ }^{3}$ though there were still striking differences in the wages paid in different parts; and the improvement, though partly due to increased earnings, was mainly attributable to the cheapening of the necessaries of life.

The great majority of ordinary labourers were hired by the

1 Parliamentary Reports, Commissioners (1897), xv. 31.

2 Ibid. p. 37 :

NUMBER OF AGRICULTURAL LABOURERS IN ENGLAND AND WALES.
1871 .
I 88 I.
1891.
1901 .
996,642
890,174
798,912
595,702

The figures for 1901 are from Summary Tables, Parliamentary Blue Book (C, d. I,523), p. 202, Table xxxvi.

$s$ According to the Report of the Royal Commission on Labour, 1893-4, the labourer was 'better fed, better dressed, his education and language improved, his amusements less gross, his cottage generally improved, though generally on small estates there were many bad ones still left ':-Parliamentary Reports, 1893 , xxxv, Index 5 et seq. 
week, except those boarded in the farm-house, who were generally hired by the year. Men, also, who looked after the live stock were hired by the year. Weekly wages ranged from Ios. in Wilts. and Dorset to $18 s$. in Lancashire, and averaged $13 \dot{s}$. $6 d$. for the whole country.

The fall in the prices of agricultural produce is best represented in tabular form:

TrienNial Average of British Wheat, Barley, AND OATS PER QUARTER.

\begin{tabular}{|c|c|c|c|}
\hline & $\begin{array}{c}\text { Wheat. } \\
\text { s. } d \text {. }\end{array}$ & $\begin{array}{c}\text { Barley. } \\
\text { s. d. }\end{array}$ & $\begin{array}{l}\text { Oats. } \\
\text { s. d. }\end{array}$ \\
\hline & 499 & $\begin{array}{ll}38 & 4\end{array}$ & \\
\hline & 24 I & 240 & 16 \\
\hline
\end{tabular}

Thus wheat had fallen $5^{2}$ per cent., barley 37 , and oats 34 .

Triennial Average Prices of British Cattle, Per STONE OF $8 \mathrm{LB}$.

\begin{tabular}{|c|c|c|c|}
\hline Inferior 9 & $\begin{array}{l}\text { uality. } \\
\text { s. } d .\end{array}$ & $\begin{array}{l}\text { Second quality. } \\
\text { s. d. }\end{array}$ & $\begin{array}{l}\text { First quality. } \\
\qquad s . d .\end{array}$ \\
\hline I 876-8 & 45 & 56 & 60 \\
\hline $1893-5$ & 28 & 40 & 47 \\
\hline
\end{tabular}

Or a fall of 24 per cent. in the best quality, and 40 per cent. in inferior grades.

The decline in the prices of all classes of sheep amounted on the average to from 20 to 30 per cent., and in the price of wool of from 40 to 50 per cent.; that is, from an average of Is. $6 d$. a lb. in $1874^{-6}$, to a little over $9 d$. in $189.3-5$.

Milk, butter, and cheese were stated to have fallen from 25 to 33 per cent. between I 874 and $189 \mathrm{I}$, and there had been a further fall since. In districts, however, near large towns there had been much less reduction in the price of milk.

This general fall in prices seems to have been directly/ connected with the increase of foreign competition ${ }^{1}$. Wheat

JParliamentary Reports, Commissioners (1897), xv. 53, 85. Sir Robert Giffen suggested that the decline in the price of wheat may be partly attributed to the great increase in the supply and consumption of meat. 
has been most affected by this development, and at the date of the Commission the home production had sunk to 25 per cent. of the total quantity needed for consumption. Other home-grown cereals had not been similarly displaced, but the large consumption of maize had affected the price of feeding barley and oats. As regards meat, while foreign beef and mutton had seriously affected the price of inferior British grades, the influence on superior qualities had been much less marked. Foreign competition had been, on the whole, perhaps more severe in pork than in other classes of meat, but had been confined mainly to bacon and hams.

The successful competition of the foreigner in our butter and cheese markets was attributed mainly to the fact that the dairy industry is better organized abroad than in Great Britain.

The Commission found that another cause of the depression was the increased cost of production, not so much from the increase of wages, as from the smaller amount of work done for a given sum. Where wages in the previous twenty years had remained stationary, the cost of work had increased because the labourer did not work so hard or so well as his forefathers.

The following table ${ }^{1}$ is a striking proof of the increased ratio of the cost of labour to gross profits :

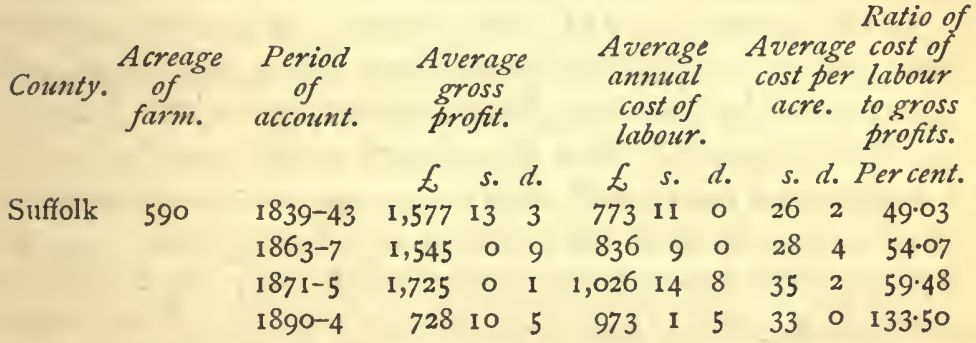

On a farm in Wilts., between $185^{8}$ and 1893 , the ratio of the cost of labour to gross profits had increased from

1 Parliamentary Reports, Commissioners (1897), xv, App. iii, Table viii. From an examination of the accounts of seventy-seven farms, the average expenditure on labour was found to be $31 \cdot 4$ per cent. of the total outlay. 
47.0 per cent. to 88.3 per cent.; on one in Hampshire, between 1872 and 1890 , from 44.4 per cent. to 184.3 per cent.; and many similar instances are given, illustrating very forcibly the economic revolution which has led to the transfer of a larger share of the produce of the land to the labourer.

On the other hand, this Commission found, like the last, that the farmer had derived considerable benefit from the decrease in cost of cake and artificial manure, while the low price of corn had led to its being largely used in place of linseed and cotton cakes.

Before leaving the subject of this famous Commission it is well to state the answer of Sir John Lawes, than whom there was no higher authority, to the oft-repeated assertion that high farming would counteract low prices. 'The result of all our experiments,' he said, 'is that the reverse is the case. As you increase your crops so each bushel after a certain amount costs you more and more... the last bushel always costs you more than all the others.' As prices went lower 'we must contract our farming to what I should call the average of the seasons'; and in the corn districts, the higher the farmer had farmed his land by adding manure the worse had been the financial results. ${ }^{1}$

In 1896 the injustice of the incidence of rates on agricultural land was partly remedied, the occupier being relieved of half the rates on the land apart from the buildings, which Act was continued in IgOr. $^{2}$ But the system is still inequitable, for a farmer who pays a rent of $£ 240$ a year even now probably pays more rates than the occupier of a house rated at $£$ I20 a year. Yet the farmer's income would very likely not be more than $£ 200$ a year, whereas the occupier of the house rated at $£$ I 20 might have an income of $£ 2,000$ a year.

In 1901 and $1902 \mathrm{Mr}$. Rider Haggard, following in the footsteps of Young, Marshall, and Caird, made an agricultural tour

1 Parliamentary Reports, Commissioners (1897), xv. Io6. But see above, p. 271 .

$2.59 \& 60$ Vict., c. 16 ; I Edw. VII, c. I3. 
through England. He considered that, after foreign competition, the great danger to English farming was the lack of labour, ${ }^{1}$ for young men and women were everywhere leaving the country for the towns, attracted by the nominally high wages, often delusive, and by the glamour of the pavement. Yet the labourer has come better out of the depression of the last generation than either landowner or farmer: he is better housed, better fed, better clothed, better paid, but filled with discontent. Since Mr. Haggard wrote, however, there seems to be a reaction, small indeed but still marked, against the townward movement, and in most places the supply of labour is sufficient. The quality, however, is almost universally described as inferior; the labourer takes no pride in his work, and good hedgers, thatchers, milkers, and men who understand live stock are hard to obtain ${ }^{2}$; and the reason for this is in large measure due to the modern system of education which keeps a boy from farm work until he is too old to take to it. His wages to-day in most parts are good; near manufacturing towns the ordinary farm hand is paid from $I 8 s$. to $20 s$. a week with extras in harvest, and in purely agricultural districts from I 3 s. to I 5s. a week, often with a cottage rent free at the lower figure. His cottage has improved vastly, especially on large estates, though often leaving much to be desired, and the rent usually paid is $£ 4$ or $£ 5$ a year, rising to $£ 7$ and $£ 8$ near large towns. The wise custom of giving him a garden has spread, and is nearly always found to be much more helpful than an allotment. The superior or more skilled workmen, ${ }^{3}$ such as

1 Rurnl England, ii. 539. Yet the census returns of 1871, 1881, and 1891 gave no support to the idea that young men were leaving agriculture for the towns. See Parl. Reports (1893), xxxviii. (2) 33.

2 The author speaks from information derived from answers to questions addressed to landowners, farmers, and agents in many parts of England, to whom he is greatly indebted.

3 It is, however, a fallacy to assume, as is nearly always done, that the ordinary farm labourer, at all events of the old type, is unskilled. A good man, who can plough well, thatch, hedge, ditch, and do the innumerable tasks required on a farm efficiently, is a much more skilled worker than many who are so called in the towns. 
the wagoner, stockman, or shepherd, earns in agricultural counties like Herefordshire from I4s. to I8s. a week, and in manufacturing counties like Lancashire from 20s. to $22 s$. a week, with extras such as $3 d$. a lamb in lambing time. At the lower wages he often has a cottage and garden rent free.

The improved methods of cutting and harvesting crops have so enabled the farmer to economize labour that the once familiar figure of the Irish labourer with his knee-breeches and tall hat, who came over for the harvest, has almost disappeared. Women, who formerly shared with the men most of the farm work, now are little seen in most parts of England at work in the fields, and are better occupied in attending to their homes.

The divorce of the labourer from the land by enclosure had early exercised men's minds, and many efforts were made to remedy this. About 1836 especially, several landowners in various parts of England introduced allotments, and the movement spread rapidly, so that in 1893 the Royal Commission on Labour stated that in most places the supply was equal to or in excess of the demand. ${ }^{1}$ However, previous Allotments and Small Holdings Acts not being considered so successful as was desired, in Igoz an effort was made to give more effect to the cry of 'back to the land' by a Small Holdings and Allotments Act ${ }^{2}$ which enables County Councils to purchase land by agreement or take it on lease, and, if unable to acquire it by agreement, to do so compulsorily, in order to provide small holdings for persons desiring to lease them. The County Council may also

1 Parl. Reports (1893), xxxv. Index.

27 Edw. VII, c. 54, amending the Allotments Acts of 1887 and 1890 and the Small Holdings Act of 1892 . The Allotments Act of 1887 defined an 'allotment' as any parcel of land of not more than 2 acres held by a tenant under a landlord; but for the purposes of the Acts of 1892 and 1907 a 'small holding' means an agricultural holding which exceeds one acre and either does not exceed 50 acres or, if exceeding 50 acres, is of an annual value not exceeding $£ 50$. At the same time the Act defines an allotment as a holding of any size up to 5 acres, so that up to that size a parcel of land may be treated as a small holding or an allotment. 
arrange with any Borough Council or Urban District Council to act as its agent in providing and managing small holdings. The duty of supplying allotments rests in the first instance with the Rural Parish Councils, though if they do not take proper steps to provide allotments, the County Council may itself provide them.

It is a praiseworthy effort, though marked by arbitrary methods and that contempt for the rights of property, provided it belongs to some one else, that is a characteristic of to-day. That it will succeed where the small holder has some other trade, and in exceptionally favoured situations, is very probable; most of the small holders who were successful before the Act had something to fall back upon: they were dealers, hawkers, butchers, small tradesmen, \&c. There is no doubt, too, that an allotment helps both the town artisan and the country labourer to tide over slack times. Whether it will succeed in planting a rural population on English soil is another matter. It is a consummation devoutly to be wished, for a country without a sound reserve of healthy countrypeople is bound to deteriorate. The small holder, pure and simple, without any by-industry, has hitherto only been able to keep his head above water by a life which without exaggeration may be called one of incessant toil and frequent privation, such a life as the great mass of our 'febrile factory element' could not endure. And if there is one tendency more marked than another in the history of English agricul ture, it is the disappearance of the small holding. In the Middle Ages it is probable that the average size of a man's farm was 30 acres, with its attendant waste and wood; since then amalgamation has been almost constant.

It is true that the occupier of a few acres often brings to bear on it an amount of industry which is greater in proportion than that bestowed on a large farm; but the large farmer has, as Young pointed out long ago, very great advantages. $\mathrm{He}$ is nearly always a man of superior intelligence and train- 
ing. He has more capital, and can buy and sell in the best markets; he can purchase better stock, and save labour and the cost of production by using the best machinery. By buying in large quantities he gets manures, cakes, seeds, \&c., better and cheaper than the small holder.

Besides the small holders who have outside industries to fall back upon, those who are aided by some exceptionally favourable element in the soil or climate, or proximity to good markets, should do well. Yet in the Isle of Axholme, the paradise of small holders, we have seen that the Commission of 1894 reported that distress was severe. This, however, seems to have been largely due to the exaggerated landhunger in the good times, which induced the tenants to buy lands at too high a price; and under normal conditions, such as they are now returning to, the tenants seem to thrive. In this district the preference for ownership as opposed to tenancy is, in spite of recent experiences, unqualified, though it is admitted that the best way is to begin by renting and save enough to buy. ${ }^{1}$ The soil is peculiarly favourable to the production of celery and early potatoes; and large tracts of land are divided into unfenced strips locally known as 'selions' of from a quarter of an acre to 2 acres each, cultivated by men who live in the villages, each having one or more strips, some as much as 20 acres, and it is considered that Io acres is the smallest area on which a man can support a family without any other industry to help him.

Yet in the fen districts and on the marsh lands between Boston and the east coast of Lincolnshire, where the land is naturally very productive, many people are making livings out of 5 or 6 acres, mainly by celery and early potatoes. ${ }^{2}$ Other districts adapted naturally to small holdings are those of Rock and Far Forest, the famous Vale of Evesham, the Sandy and Biggleswade district of Bedfordshire; Upwey, Dorset ; Calstock and St. Dominick, Cornwall; Wisbech, Cambridgeshire ;
1 Jebb, Small Holdings, p. 25.
${ }^{2} \mathrm{Jebb}, o p$. cit. p. 28. 
and Tiptree, Essex. A part, however, from by-industries, and exceptional climate, soil, and situation, the small holding for the purpose of raising corn and meat, as distinguished from that which is devoted to dairying, fruit-growing, and market gardening, does not seem to-day to have much chance of success. If farms were still self-sufficing, and simply provided food and clothing for the farmer, the small producer even of corn and meat might do as well as the larger farmer on a lower scale, but such conditions have gone; all holdings now are chiefly manufactories of food, and the smaller manufactory has little chance in competition with the greater.

The example of foreign countries is usually held up to Englishmen in this connexion, and the argument naturally used is that 'if small holdings answer in France and Belgium, why can they not do so in England?' On this point the testimony of Sir John Lawes is worth quoting.' 'In most, if not in all continental countries,' he says, 'the success of small holdings depends very materially on whether or not the soil and the climate are suitable for what may be called industrial crops: such as tobacco, hops, sugar beet, colza, flax, hemp, grapes, and other fruit and vegetables; where these conditions do not exist the condition of the cultivators is such as would not be tolerated in this country.' That is the reason probably why small holdings, apart from exceptional conditions, do not answer in England; the Englishman of to-day is not anxious to face the hard and grinding conditions under which the continental small holder lives.

Since Mr. Haggard's tour the black clouds which have so long lowered over agriculture have shown signs of lifting. Rents have been adjusted to a figure at which the farmer has some chance of competing with the foreigner, ${ }^{2}$ though the

1 Allotments and Small Holdings (1892), p. 19 et seq.

2 The gross income derived from the ownership of lands in Great Britain, as returned under Schedule A of the Income Tax, decreased from $£ 51,811,234$ in $1876-7$ to $£ 36,609,884$ in $1905-6$. In 1850 Caird estimated the rental of English land, exclusive of Middlesex, at $£ 37,412,000$. Cf. above, p. 310. 
price of grain keeps wretchedly low ; stock has improved, and there is undoubtedly to-day (1908) a brisker demand for farms, and in some localities rents have even advanced slightly. The yeoman-that is, the man who owns and farms his own land, perhaps the most sound and independent class in the community-has, unfortunately for England, largely disappeared. Even of those who remain, some prefer to let their property and rent holdings from others! It has been noticed that the labourer's lot has improved in this generation of adversity; and well it might, for his previous condition was miserable in the extreme. The farmers have suffered severely, many losing all their capital and becoming farm labourers. The landlords have suffered most; they have not been able to throw up their land like the farmer, and until quite recently have watched it becoming poorer and poorer. The depression, in short, has driven from their estates many who had owned them for generations. Those who have survived have usually been men with incomes from other sources than land, and they have generally deserved well of their country by keeping their estates in good condition in spite of falling rents and increasing taxation.

No class of men, indeed, have been more virulently and consistently abused than the landlords of England, and none with less justice. There have been many who have forgotten that property has its duties as well as its rights; they have erred like other men, but as a rule they play their part well. Even the worst are to some extent obliged by their very position to be public spirited, for the mere possession of an estate involves the employment of a number of people in healthy outdoor occupations which Englishmen to-day so especially need to counteract the degenerating influences of town life. Many of the great estates ${ }^{1}$ are carried on at a

1 According to the Commission of 1894 , the amount expended on improvements and repairs alone on some great estates was: On Lord Derby's, in Lancashire, of 43,217 acres, $£ 200,000$ in twelve years, or $£ 16,500$, or $7 s .8 d$. an acre, each year. On Lord Sefton's, of 18,000 acres, $£ 286,000$ in twenty-two years, or about $£ 13,000$, or 14 s. an acre, each 
positive loss to their owners, and it may be doubted whether agricultural property pays the possessor a return of 2 per cent. per annum; which is as much as to say that the landlord furnishes the tenant with capital in the form of land at that rate for the purpose of his business. What other class is content with such a scanty return? They are often charged with not managing their estates on business principles, and no charge is worse founded. It would be a sad day for the tenants on many an estate if they were managed on commercial lines. One of the first results would be that many properties would be given up as a dead loss. They could only be made to pay by raising the rents or cutting down the ever-recurring expenditure on repairs and buildings which are necessary for the welfare of the tenants. The Duke of Bedford, in his Story of a Great Estate, has said that the rent has completely disappeared from three of his estates. On the Thorney and Woburn estates over $£ 750,000$ was spent on new works and permanent improvements alone between 1816 and 1895 , and the result, owing to agricultural depression and increased burdens on the land, was a net loss of $£ 7,000$ a year; and every one with any knowledge of the management of land knows that this is no isolated case, though it may be on an exceptionally large scale. Where would many tenants be if commercial principles ruled on rent audit days? The larger English landlords of to-day are as a rule not dependent on their rent rolls. To their great advantage, and to the advantage of their tenants, they generally own other property, so that they need not regard the land as a commercial investment. They can therefore support the necessary outlay on a large estate, the capital expenditure on improvements of all kinds, and thus relieve the tenant of any expense of this kind. The farms are let at moderate, not rack year. On the Earl of Ancaster's estates in Lincolnshire, of 53,993 acres, $£ 689,000$ was spent in twelve years, or II s. $7 d$. an acre each year; and many similar instances are given.-Parliamentary Reports, Commissioners (1897), xv. 287-9. 
rents, such as the tenants can easily pay. Also the landlord can make large reductions of rent in years of exceptional distress. ${ }^{1}$ Rents are generally collected three months after they are due, a considerable concession; and even then arrears are numerous, for any reasonable excuse for being behind with the rent is generously listened to. It is owing to forbearance in this and other matters that the relations between landlord and tenant are generally excellent. Where are the best farm buildings, where the best cottages, where does the owner carry on a home farm often for the assistance of the tenant by letting him have the use of entire horses, well-bred bulls, and rams, if not on the larger estates? The restrictions in leases, so much decried of late years, were nearly always in the interest of good farming, and their abolition will lead to the deterioration of many a holding.

Bacon said, "Where men of great wealth do stoop to husbandry, it multiplieth riches exceedingly, and wiser words were never uttered. Yet these are the men who are singled out for attack by agitators, who are only listened to because the greater number of modern Englishmen are ignorant of the land and everything connected with it. At a time when rents have dwindled, in some cases almost to vanishing point, taxation has increased, and confiscatory schemes and meddlesome restrictions have frightened away capital from the land. Many of the landlords of England would clearly gain by casting off the burden of their heavily weighted property, but they nearly all stick nobly to their duty, and hope for that restoration of confidence in the sanctity of property and of respect for freedom of contract which would do so much towards the rehabilitation of what is still the greatest and most important industry in the country.

1 Shaw Lefevre, Agrarian Tenures, p. 19. 


\section{CHAPTER XXII}

\section{IMPORTS AND EXPORTS. - LIVE STOCK}

IT is a curious fact that the barriers which protected the British farmer were thrown down shortly before he became by unforeseen causes exposed to the competition of the whole world. Down to I 846 Germany supplied more than half the wheat that was imported into England, Denmark sent more than Russia, and the United States hardly any. Other competitors who have since arisen were then unknown. By the end of the next decade Russia and the United States sent large quantities, as may be gathered from the following table ${ }^{1}$ :

ANNUAL Ayerage Imports of Wheat aNd Flour For THE SEVEN YEARS 1859-1865.

Crut.

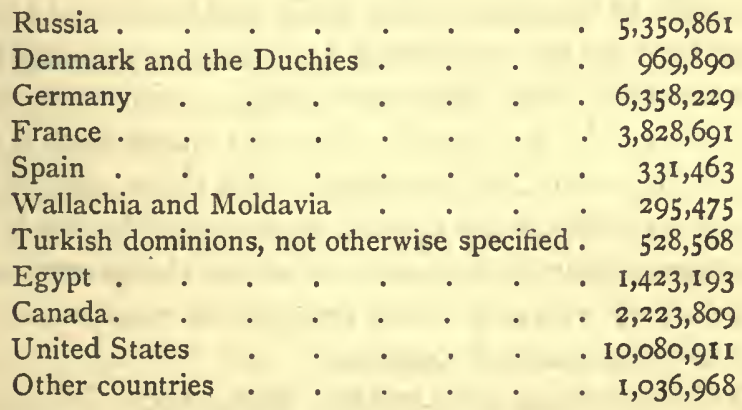

In the years $1871-5$ the United States held the first place, Russia came next, and Germany third with only about onesixth of the American imports, and Canada was running

${ }^{1} \mathrm{M}^{\circ} \mathrm{Culloch}$, Commercial Dictionary (1882), p. 449. 
Germany close. Other formidable competitors were now arising, and by 1 gor the chief importing countries were ${ }^{1}$ :

Crut.

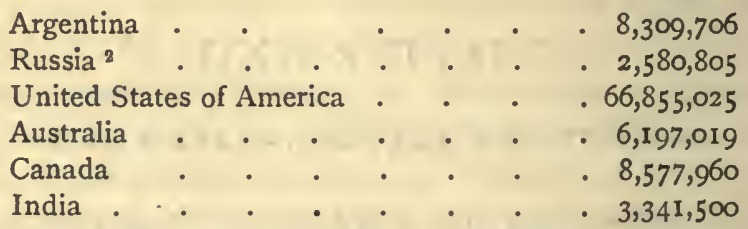

Since then the imports of wheat and flour from the United States have decreased, and in 1904 India took the first place, Russia the second, Argentina the third, and the United States the fourth. However, in 1907 the United States sent more than any other country, followed by Argentina, India, Canada, Russia, and Australia, in the order named.

It is probable in the near future that the imports from the United States will decline considerably, for in the last quarter of a century its population has increased 68 per cent. and its wheat area only 25 per cent. On the other hand, the population of Canada increased 33 per cent. and her wheat area I $5^{8}$ per cent. in the same time; while in Argentina an addition of 70 per cent. to the population has been accompanied by an increase of the wheat area from half a million to fourteen million acres. It is probable also that India and Australia will continue to send large supplies, and there are said to be vast wheat-growing tracts opened up by the Siberian Railway, so that there seems little chance of wheat rising very much in price for many years to come, apart from exceptional causes such as bad seasons and 'corners'.

$\mathrm{M}^{\mathrm{C}} \mathrm{Culloch}$, writing in $\mathrm{I} 843,{ }^{3}$ says that, except Denmark and Ireland, no country of Western Europe 'has been in the habit of exporting cattle'. Danish cattle, however, could rarely be

1 See Returns of the Board of Agriculture.

2 The imports from Russia were that year exceptionally small.

${ }^{3} \mathrm{M}^{\mathrm{C} C} \mathrm{Culloch}$, Commercial Dictionary (1852), p. 274. 
sold in London at a profit, and Irish cattle alone disturbed the equanimity of the English farmer.

For a few years after the repeal of the corn laws and of the prohibition of imports of live stock, the imports of live stock, meat, and dairy produce were, except from Ireland, almost nil ${ }^{1}$; since then they have increased enormously, and in 1907 the value of live cattle, sheep, and pigs imported was $£ 8,273,640$, not so great, however, as some years before, owing to restrictions imposed; but this decrease has been made up by the increase in the imports of meat, which in 1907 touched their highest figure of $18,751,555 \mathrm{cwt}$., valued at the large sum of $£ 41,697,905 .^{2}$

Forty years ago hardly any foreign butter or cheese was imported; to-day it is perhaps no exaggeration to say that not one hundredth part of the butter eaten in London is British; in 1907 the amount of butter imported was $4,210,156 \mathrm{cwt}$., and of cheese, 2,372,233 cwt. The increase in the imports was 1 largely assisted by the fact that in the last half of the nineteenth century English farmers had directed their attention chiefly to meat-producing animals and neglected the milch cow. However, of late years great efforts have been made to recover lost ground, and in England the number of cows and heifers in milk or in calf has increased from $1,567,789$ in 1878 to $2,020,340$ in 1906 .

The regulation of the imports and exports of live stock did not concern the legislature so early as those of corn. One of the earliest statutes on the subject is $x I$ Hen. VII, c. 13 , which forbade the export of horses and of mares worth more than $6 s .8 d$., because many had been conveyed out of the land, so that there were few left for its defence and the price of horses had been thereby increased. A subsequent statute, $22 \mathrm{Hen}$. VIII, c. 7, says this law was disobeyed by many who secretly exported

1 In 1860 the number of live cattle imported was 104,569; in 1897, 618,321 ; in $1907,472,015$.

2 In 1860 the quantity of beef imported was $283,332 \mathrm{cwt}$; in 1907 , $6,033,736 \mathrm{cwt}$. 
horses, so it was enacted that no one should export a horse without a licence ; and I Edw.VI, c. 5, continued this. But after this date the export of horses does not seem to have occupied the attention of Parliament.

22 Hen. VIII, c. 7, also forbade the export of cattle and sheep without a licence because so many had been carried out of the realm that victual was scarce and cattle dear. By 22 Car. II, c. I3, oxen might be exported on payment of a duty of Is. each, the last statute on the subject.

As for sheep, their export without the king's licence had been forbidden by 3 Hen. VI, c. 2, because men had been in the habit of taking them to Flanders and other countries, where they sheared them and sold the wool and the mutton. 8 Eliz., c. 3 , forbade their export, and I 3 and I 4 Car. II, c. I8, declared the export of sheep and wool a felony.

The importation of cattle was forbidden by I 5 Car. II, c. 7, which stated that the "comeing in of late of vast numbers of cattle already fatted 'had caused 'a very great part of the land of this kingdom to be much fallen and like dayly to fall more in their rents and values'; therefore every head of great cattle imported was to pay $20 s$. to the king. Ios. to the informer, and 10s. to the poor after July I, 1664. By 18 Car. II, c. 2 , the importation of cattle was declared a common nuisance, and if any cattle, sheep, or swine were imported they were to be seized and forfeited. By $3^{2}$ Car. II, c. 2, this was made perpetual and continued in force till 1842 , though it was repealed as to Ireland, as we have seen. ${ }^{1}$

It appears from the laws dealing with the matter that in the time of the Plantagenets England exported butter and cheese. In the reign of Edward III they were merchandise of the staple, and therefore when exported had to go to Calais when the staple was fixed there. This caused great damage, it is said, to divers persons in England, for the butter and cheese would not keep until buyers came; therefore 3 Hen. 
VI, c. 4, enacted that the chancellor might grant licence to export butter and cheese to other places than to the staple.

The regulation of the export of wool frequently occupied the attention of Parliament. It has been noticed ${ }^{1}$ that the laws of Edgar fixed its price for export, and Henry of Huntingdon mentions its export in the twelth century, while during the reign of Edward $I$ it was for some time forbidden except by licence, which led to its being smuggled out in wine casks. ${ }^{2}$ The Hundred Rolls give the names of several Italian merchants who were engaged in buying wool for export, the ecclesiastical houses, especially the Cistercians, furnishing a great quantity, and the chief port then for the wool trade was Boston. The export was again prohibited in 1337 , the great object being to make the foreigner pay dearly for our staple product : an object which was certainly effected, for when Queen Philippa redeemed her crown from pawn at Cologne in 1342 by a quantity of English wool, Is. $3 \frac{1}{2} d$. a lb. was the price, and it was even said to sell in Flanders at $3 s$. a $1 \mathrm{~b}$, a price which, expressed in modern money, seems fabulous. ${ }^{3}$ However, in the next reign English wool began to decline in price, owing probably to changes in fashion, but the long wools maintained their superiority and their export was forbidden by Henry VI and Elizabeth. ${ }^{4}$

In the reign of James I it was confessed 'that the cloth of this kingdom hath wanted both estimation and vent in foreign parts, and that the wools are fallen from their stated values', so that export was prohibited entirely; and 13 and I 4 Car. II, c. 18, declared the export of wool a felony, though 7 and 8 Will. III, c. 28, says this did not deter people from exporting it, so that the law was made more stringent on the subject, and export continued to be forbidden until $18255^{5}$ In

1 Supra, p. 38.

2 Cunningham, Industry and Commerce, i. 176, 192 ; Hundred Rolls, i. $405,4 \mathrm{I} 4$.

3 Burnley, History of Wool, p. 65.

Ibid. p. 70.

- Cf. supra, p. I72. 
a letter written in 1677 the fall of rents in England, which had caused the value of estates to sink from twenty-one to sixteen or seventeen years' purchase, is ascribed mainly to the low price of wool, ${ }^{1}$ owing to the prohibition of export and increased imports from Ireland and Spain. It was now, said the writer, worth $7 d$. instead of $12 d$., and a great quantity of Spanish wool was being sold in England at low rates. These 'low rates' were $2 s$. and $2 s .2 d$. a lb. for the best wool, whereas in 1660 the best Spanish wool was $4 s$. and $4 s .2 d$. a lb.

We have seen ${ }^{2}$ that Spanish wool was imported into England in the Middle Ages. In 1677 , according to Smith, ${ }^{3}$ England imported 2,000 bags of $200 \mathrm{lb}$. each from Spain ${ }^{4}$; in the three years I 709-II, I 4,000 bags; in the three years I 7 I 2-I 4, 20,000 bags ; and about I 730 some came from Jamaica, Maryland, and Virginia, and down to 1802 imports were free. ${ }^{5}$ In that year a duty of 5 s. 3 d. a cwt. was imposed, which in $18 \mathrm{I} 9$ was raised to $56 s$. a cwt., which, however, was reduced to $\mathrm{I} d$. a $\mathrm{lb}$. on $\mathrm{I} s$. wool and $\frac{1}{2} d$. a lb. on wool under Is. in 1824 . In I 825 colonial wool was admitted free, and in 1844 the duty taken off altogether, and imports from our colonies and foreign countries soon assumed enormous proportions. Down to 18 I 4 nearly all our imports of wool came from Spain ; after that the greater part came from Germany and the East Indies; but Russia and India soon began to send large quantities, and in recent times Australasia has been our chief importer, in 1907 sending $321,470,554 \mathrm{lb}$, while New Zealand sent $158,406,255 \mathrm{lb}$. out of a total import of $764,286,625 \mathrm{lb}$. About 1800 our imports of wool were $8,609,368 \mathrm{lb} . !^{6}$ Of our enormous imports of wool, however, a very large quantity is re-exported.

1 Smith, Memoirs of Wool, i. 222.

2 See above, p. 38. 3 Smith, Memoirs of Wool, ii. 252.

$4 \mathrm{M}$ Pherson, Annals of Commerce, iii. 156.

$5 \mathrm{M}^{\mathrm{C}} \mathrm{Culloch}$, Commercial Dictionary, p. I431. For imports see Appendix, p. 354 .

6 Of which 6,000,000 lb. came from Spain. The first Spanish Merino sheep were introduced into Australia in 1797. See Cunningham, Industry and Commerce, ii. 538, and cf. below, p. 354 . 
In 1828 it was stated before the House of Lords that English wool had deteriorated considerably during the previous thirty years, owing chiefly to the farmer increasing the weight of the carcase and the quantity of wool, so that fineness of fleece was injured. The great extension of turnips and the introduction of a large breed of sheep also appeared to have lessened the value of the fleece, yet English wool to-day still commands a high price in comparison with that of other countries, though the price in recent years has declined greatly; in $187 \mathrm{I}$ it was Is. $5 \frac{1}{2} d . \mathrm{a} \mathrm{lb}$., in $1872 \mathrm{Is} .9 \frac{1}{2} d$., in 1873 is. $7 d$. In 1907 Leicester wool was $12 \frac{1}{2} d$., Southdown $14 d$. to $15 d$., and Lincoln $\mathrm{I} 2 d$. a $1 \mathrm{~b}$.; Australian at the same date being I $1 d$., and New Zealand II $\frac{1}{2} d$.

The fruit-grower has also had to contend with an enormous foreign supply, which nearly always has a better appearance than that grown in these islands, though the quality is often inferior. In 1860 apples were included with other raw fruits in the returns, so that the exact figures are not given, but apparently about $500,000 \mathrm{cwt}$. came in ; by 1903 this had increased to $4.5^{6} 9,546$ bushels, and in $19073,526,23^{2}$ bushels arrived. Enormous foreign supplies of grapes, pears, plums, cherries, and even strawberries have also combined to keep the home price down.

The decrease in the acreage of hops, from its maximum of 71,789 acres in 1878 to $44,93^{8}$ in 1907 , was ascribed by the recent Commission to the lessening demand for beer in England, the demand for lighter kinds of beer, and the use of hop substitutes, and not to increase in foreign competition; which the following figures seem to bear out:

IMPORTS OF HOPS.

Crot.

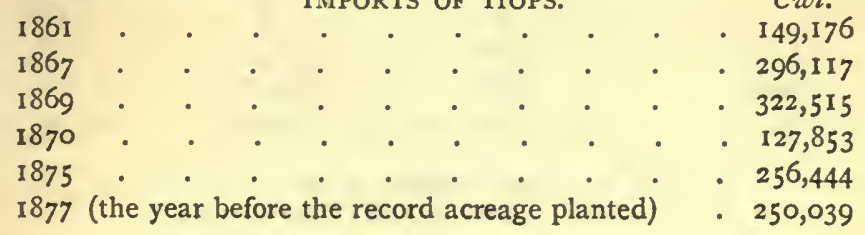


Cwt.

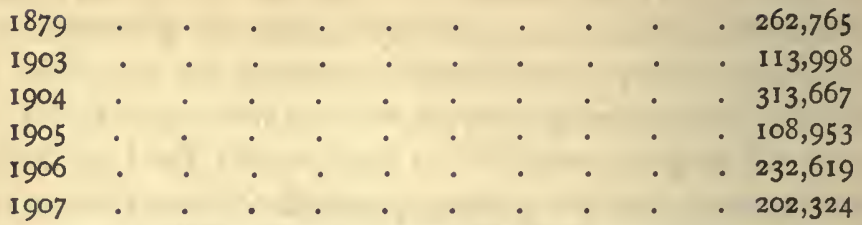

In recent years they have been a loss to the grower; as the average crop is a little under $9 \mathrm{cwt}$. per acre, and the total cost of growing and marketing from $£ 35$ to $£ 45$ an acre, it is obvious that prices of about $£ 3$ per cwt., which have ruled lately, are unremunerative.

However disastrous to the farmer and landowner, the increased quantities and low prices of food thus obtained have been of inestimable benefit to the crowded population of England. In $185^{1}$ the whole corn supply, both English and foreign, afforded $317 \mathrm{lb}$. per annum per head of the population of 27 millions. In 1889 the total supply gave $400 \mathrm{lb}$. per head to a population of $37 \frac{1}{2}$ millions at a greatly reduced cost. ${ }^{1}$ The supply of animal food presents similar contrasts; in I $85 \mathrm{I}$ each person obtained $90 \mathrm{lb}$., in I889 II $5 \mathrm{lb}$. The average value of the imports of food per head in the period $1859-65$ was about $25 \mathrm{s.}$; in the period I9oI $-7,65 \mathrm{s.}^{2}$ The products which have stood best against foreign competition are fresh milk, hay and straw, the softer kinds of fruit that will not bear carriage well, and stock of the finest quality. These islands still maintain their great reputation for the excellent quality of their live stock, and exports, chiefly of pedigree animals, touched their highest figure in 1906 :

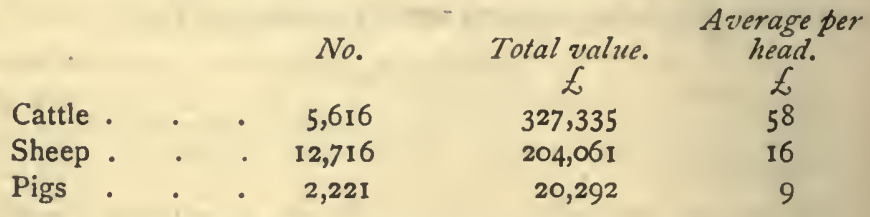




$$
1877^{1}
$$

Acreage under crops and grass in England 24,312,033

Corn crops.

Wheat .

- 2,987,129

Barley or bere . 2,000,53 I

Oats

Rye

Beans

Peas

$$
\begin{aligned}
& \text { - . I,489,999 } \\
& \begin{array}{rr}
\cdot & 470,153 \\
\text { Total } & 306,356 \\
\hline 7,302,772
\end{array}
\end{aligned}
$$

Green crops.

Potatoes

Turnips and swedes . I,495,885

Mangels

348,289

Carrots

14,445

Cabbage, kohl rabi, and rape . 176,218

Vetches and other green crops.

$$
\text { Total } \frac{420,373}{2,759,174}
$$

Flax

7,210

Hops . . . 71,239

Bare fallow or uncropped arable

Clover, sainfoin, and grasses under rotation

Total arable $13,454,017$

Permanent grass, exclusive of mountain or heath land

- $10,858,016$

$24,312,033$
1907.

Total acreage under crops and grass $\quad \cdot 24,585,455$ Corn crops.

Wheat . . . I,537,208

Barley . . . . I,41 I, 163

Oats . . . . $1,967,682$

Rye . . . . 53,837

Beans . . . 296,186

Peas . . . 164,326

Total $\overline{5,430,402}$

Potatoes . . . 381,891

Turnips and swedes $\quad$ 1,058,292

Mangels . . . 436,193

Cabbage . . . 65,262

Kohl rabi . . . 20,572

Rape • . . . 79,913

Vetches or tares . . 145,067

Lucerne . . . 63,379

Hops . . . . 44,938

Small fruit . . . 73,372

Clover, sainfoin, and

grasses under rotation $2,611,722$

Other crops . . . 117,914

Bare fallow . . . 248,678

Total arable $\overline{10,777,595}$

Permanent grass $13,807,860$

$24,585,455$

The small fruit was divided into:

Strawberries . . 23,623

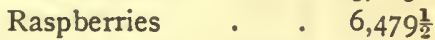

Currants and gooseberries . . 24,1783

Others . . $\because 19,090$

$73,371 \frac{1}{4}$

1 Cf. Appendix iv, p. 353. 
As arable land has suffered much more than grass from foreign imports, it was inevitable that this country should become more pastoral; in 1877 the arable land of England amounted to I $3,454,0$ I 7 acres, and permanent grass to Io,858,o I6. By I 907 this was practically reversed, the permanent grass amounting to $13,807,860$ acres and the arable to $10,777,595$. In corn crops the great decrease has been in the acreage of wheat, but barley, beans, and peas have also diminished, while oats have increased. In green crops there has been a great decrease in turnips and swedes, compensated to some extent by an increase in mangels, and a sad decrease in hops. The changes in thirty years can be gathered from the tables of the Board of Agriculture given on p. $33 \mathrm{I}$.

In 1877 no separate return of small fruit was made, but in I 878 the orchards of England, including fruit trees of any kind, covered 161,228 acres, which by 1907 had grown to a total area under fruit of 294,9 Io acres, among which were 168,576 acres of apples, 8,365 of pears, I I,952 of cherries, and 14,57 I of plums. Much of the small fruit is included in the orchards.

'Other crops' were further divided into:

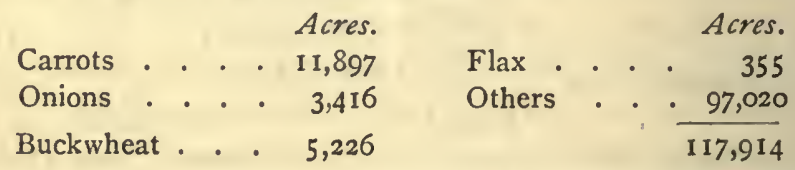

The average yield per acre of various crops in England for the ten years $1897-1906$ was :

Bushels.

\begin{tabular}{|c|c|c|c|c|c|c|c|}
\hline Wheat & & & & & & - & . $31.15^{1}$ \\
\hline Barley & • & • & • & . & $\bullet$ & • & - 32.88 \\
\hline Oats & - & - & . & . & 6 & • & - $41 \cdot 38$ \\
\hline Beans . & . & - & • & . & 0 & • & - $29 \cdot 28$ \\
\hline Peas. & . & . & . & . ... & . & . & - $27 \cdot 15$ \\
\hline
\end{tabular}

' In 1907 the average wheat crop was 33.96 bushels per acre in England and 39.18 in Scotland. The average yield per acre of wheat in Holland is 34.1 bushels; Belgium, 34 ; Germany, 30.3; Denmark, 28.2 ; France, 19.7 . 
Tons.

Potatoes . . . . . . . 5.74

Turnips and swedes : . . . . 12.19

Mangels . . . . . . . $19 \cdot 24$

Cwt.

Hay from clover, and grasses under rotation . 29.40

Hay from permanent grass . . . . 24.33

Hops . . . . . . . . $8.8 \mathrm{I}$

The live stock in 1877 consisted of :

Horses used solely for purposes of agriculture . . . 761,089

Unbroken horses and mares kept solely for breeding . • 309,119

I,070,208

Cattle. Cows and heifers in milk or in calf . . . . 1,557,574

Two years old and over . . . . . . 1,072,407

Under two years of age . . . . . . 1,349,669

$3,979,650$

Sheep

Pigs

In 1907 :

Horses used solely for agriculture . . . . . . 863,817

Unbroken

$18,330,377$

2, I I 4,75 I

Cattle. Cows and heifers in milk or in calf . . . . $\frac{1,189,147}{2,032,284}$

Two years old and over . . . . . . I, $1,043,034$

Under two years of age . . . . . . $1,912,413$

$4,987,731$

Sheep $^{1}$. . . . . . . . . . . $15,098,928$

Pigs . . . . . . . . . . $2,257,136$

The decrease in sheep and the increase in cattle and horses (though of late years the latter have shown a tendency to decrease) are to be noted.

1 The total number of sheep in Great Britain in 1877 was $28,161,164$; in $1907,26,115,455$. In 1688 Youatt estimates it at 12,000,000; in 174I, I7,000,000; in $1800,26,000,000$; in 1830, $32,000,000$. 
The number of live stock per 1,000 acres of cultivated land in the United Kingdom and other countries is :

\begin{tabular}{|c|c|c|c|c|}
\hline Country. & Cattle. & Sheep. & Pigs. & Total. \\
\hline United Kingdom & 247 & $619^{\circ}$ & 76 & 942 \\
\hline Belgium & . $4 \mathrm{II}$ & 54 & 240 & 705 \\
\hline Denmark . & . 264 & 126 & 209 & 599 \\
\hline France & - 167 & 207 & 88 & 462 \\
\hline Germany & . $22 \mathrm{I}$ & 90 & 216 & 527 \\
\hline Holland & . 322 & 116 & 164 & 602 \\
\hline
\end{tabular}

It will be observed that in cattle the United Kingdom comes out badly, but is pre-eminent in sheep and has the largest total ; though, as cattle require more acreage, Belgium nearly equals its aggregate produce for $\mathrm{I}, 000$ acres.

As regards prices at the two periods $187 \mathrm{I}-5$ and $1906-7$, if we take 100 as the price at the former the following are the prices at the latter:

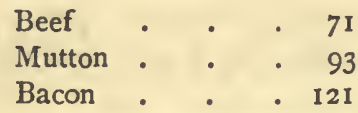

$\begin{array}{rrr}\text { Wheat : } & \text { : } & 56 \\ \text { Butter : } & \text { : } & 97 \\ \text { Cheese } & \text { - } & \text { roo }\end{array}$

Turning once more to the occupation of land, the percentage of land occupied by owners in 1907 in England was 12.4 , the rest being occupied by tenants, and the following is a statement of the number of agricultural holdings of various sizes in 1875 and 1907 :

$\begin{array}{ccllll}50 \text { acres } & 50 \text { to } & 100 \text { to } & 300 \text { to } & 500 \text { to } & \text { Above } \\ \text { and } & 100 & 300 & 500 & 1,000 & 1,000 \\ \text { under. } & \text { acres. } & \text { acres. } & \text { acres. } & \text { acres. } & \text { acres. } \\ 293,469 & 44,842 & 58,450 & 11,245 & 3,871 & 463\end{array}$

1907.

Above $\mathrm{I}$ and not Above 5 and not Above 50 and not Above 300 exceeding 5 acres. exceeding 50 acres. exceeding 300 acres. acres.
80,921
165,975
109,927
14,652

${ }^{1}$ Unfortunately the class 50 acres and under at this time included holdings under one acre, so that it is useless for the comparison of the number of small holdings at the two dates, for in 1907 none appear under one acre. 


\section{CHAPTER XXIII}

\section{MODERN FARM LIVE STOCK}

\section{CART Horses}

ARTHUR YOUNG at the end of the eighteenth century found only two kinds of cart horses worthy of mention, the Shire and the Suffolk Punch; to-day, besides these two, we have the Clydesdale.

The Shire horse, according to Sir Walter Gilbey, is the purest survival of the Great Horse of mediaeval times, known also as the War Horse, and the Old English Black Horse. It is the largest of draught horses, attaining a height of 17 to $17 \cdot 3$ hands and a weight of $2,200 \mathrm{lb}$., its general characteristics being immense strength, symmetrical proportions, bold free action, and docile disposition. In 1878 the Shire Horse Society was established to improve the breed, and distribute sound and healthy sires through the country.

The Clydesdale, whose native home is the valley of the Clyde, is not so large as the Shire, but strong, active, and a fine worker. They are either derived from a cross between Flemish stallions and Lanarkshire mares, or are an improvement of the old Lanark breed. ${ }^{1}$

The Suffolk Punch looks what he is-a thorough farm horse. He stands lower than the two former breeds, but weighs heavily, often $2,000 \mathrm{lb}$. They are generally chestnut or light dun in colour, and their legs are without the feather of the Clydesdale and Shire. They have been long associated with Suffolk, and were mentioned by Camden in 1586 . According to the Suffolk Stud Book of 1880 , the Suffolk

1 Youatt, Complete Grazier (1900), p. 388; cf. pp. 104-5. 
horses of to-day are with few exceptions the descendants in the direct male line of the original breed described by Arthur Young.

\section{Cattle}

What was the original breed of cattle in this island is uncertain. The Report of the British Association for the Advancement of Science in 1887 favours the view that the herds of wild cattle, such as still exist at Chillingham, represent the original breed of Great Britain. It states that the 'urus' was the only indigenous wild ox in this country, and the source of all our domesticated breeds as well as of the few wild ones that remain, such as the Chillingham breed, which is small, white, with the inside of the ear red, and a brownish muzzle. Some, however, assert they are merely the descendants of a domesticated breed run wild, which have reverted somewhat to the ancient type. ${ }^{1}$

According to Thorold Rogers, the cattle of the Middle Ages were small rough animals like the mountain breeds of to-day, and at the end of the sixteenth century we have seen they had large horns, were low and heavy, and for the most part black. ${ }^{2}$ The great variety of cattle in Great Britain may be due to their being the descendants of several species, or to difference of climate and soil, or to spontaneous variation, but the chief cause is the diligent selection of breeders. Marshall is quite positive ${ }^{3}$ that the Hereford, Devon, Sussex, and the black mountain breeds of Scotland and Wales are all descended from the original native breed of this island, that the Shorthorns came from the Continent, and the Longhorns probably from Ireland. Bradley's division of cattle into black, white, and red tells us little. ${ }^{4}$ There was very little attempt at improvement until the middle of the eighteenth century, for peace was necessary for long

1 Youat, Complete Grazier (1900), p. 6.

2 See p. 167.

3 Rural Economy of West of England, i. 235 ; cf. above, p. 235.

4 See above, p. 167 . 
continued effort, and 1746, the date of Culloden, the last battle fought on British soil, may be taken practically as the commencement of the era of progress.

The Shorthorn is the most famous and widely-spread breed of this country, if not in the world; it exceeds in number any other breed in the United Kingdom, and most cross-breds have Shorthorn blood in them. It adapts itself to any climate, and is equally noted for beef-making and milk-yielding.

The origin of the Shorthorns is uncertain; they originated from the Teeswater and Holderness varieties, but where these came from is a matter of dispute. Young, in his Northern Tour, ${ }^{1}$ says, 'In Yorkshire the common breed was the shorthorned kind of cattle called Holderness, but really the Dutch sort '; and many have said the Holderness and the Teeswater breeds both came from Holland, and were practically the same, while others assert the original home of the Teeswaters was the West Highlands. ${ }^{2}$

John Lawrence speaks of the Dutch breed with short horns in $1726^{3}$; but, unless they were smuggled over, it certainly seems strange that any Dutch cattle should have been imported in the eighteenth century, for the importation of cattle was strictly forbidden during the whole century. It was George Culley's opinion that they came from Holland, because few were found except along the eastern coast; he also knew farmers who went over to Holland to buy bulls. ${ }^{4}$

Be this as it may, it was the cattle of the Teeswater district in Durham that the Collings improved, and they are still called Durhams in many parts. The work of the Collings ${ }^{5}$ was carried on by Thomas Booth, who farmed his own estate of Killerby in Yorkshire, where he turned his attention to Shorthorns about 1790 , and by 1814 he was as well known as the Collings. He improved the Shorthorns by reducing the

1 ii. 126 ; about 1770.

2 Youatt, Complete Grazier, p. 18, and see 'Druid', Saddle and Sirloin.

3 Cf. supra, p. 167.

- Culley on Live Stock (1807), p. 42.

S. See p. 233. 
bone, especially the length and coarseness of the legs, the too prominent hips, and the heavy shoulder bones. In 1819 he removed to Warlaby, and died there in $\mathrm{I} 835$, having given up the Killerby estate to his son John, who with his brother Richard ably sustained their father's reputation. 'Booth strains' equally with 'Bates strains', the results of the work of Bates of Kirkleavington, whose cattle we have seen at the Oxford Show in 1839 , and whose herd was dispersed in $185^{\circ}$, have been the foundation of many famous herds, and can be traced in many a pedigree animal of to-day.

The palmy days of the Shorthorns were the 'seventies' of the last century, when they made fabulous prices. At the great sale at New York Mills, in I873, eleven females of the Duchess tribe averaged $£ 4,5^{22}$ 14s. $2 d$., and one cow sold for $£ 8,45^{8} 6 s$. $8 d$. In $1877 \mathrm{Mr}$. Loder bought Third Duchess of Hillhurst for 4,100 guineas ; in 1876 Lord Bective gave 4,300 guineas for Fifth Duchess of Hillhurst, then 16 months old; and in 1875 the bull Duke of Connaught sold for 4,500 guineas. It was not likely that with the advent of bad times these prices would continue, and nothing like them in the Shorthorn world has occurred since.

\section{Herefords. ${ }^{1}$}

Herefordshire cattle have long been famous as one of the finest breeds in the world. Marshall, writing in 1788 , does not hesitate to say, "The Herefordshire breed of cattle, taking it all in all, may without risque be deemed the first breed of cattle in the land.' Their origin has been accounted for in various ways. Some say they were originally brown or reddish-brown from Normandy or Devon, others that they came from Wales, while it is recorded that Lord Scudamore in the latter half of the seventeenth century introduced red cows with white faces from Flanders. However, they do not

1 Much of these accounts of Herefords and Devons is from the author's articles in the Victoria County History. 
emerge from obscurity until about the middle of the eighteenth century, when Messrs. Tomkins, Weyman, Yeomans, Hewer, and Tully devoted their energies to establishing a county breed. There were four varieties of Herefords, which have now practically merged into the red with white face, mane, and throat: the mottle face, with red marks intermixed with the parts usually white; the dark greys; light greys; and the red with the white face. The rivalry between the breeders of the white and the mottle faces almost caused the failure of the Herd-Book commenced in 1845 by Mr. Eyton. The mottle-faced party seems to have been then the most influential, but the dark and light grey varieties also had strong adherents. In I857 Mr. Duckham took over the management of the Herd-Book, and to his exertions the breed owes a deep debt of gratitude. One of the greatest supporters of the Herefordshire breed was Mr. Westcar of Creslow, who, starting in $\mathbf{1 7 7 9}$, attended Hereford October Fair for forty years, and when the Smithfield Show commenced in 1799 won innumerable first prizes there with Herefordshire cattle. Between I 799 and I 8 I I twenty of his Herefordshire prize oxen averaged $£ 1066 s$. each, and at the sale of Mr. Ben Tomkins's herd after his death in 1819 twenty-eight breeding animals averaged $£ I_{52}$, one cow fetching $£_{26}{ }_{2}$ I $_{5} s$. Herefords are famous for their feeding qualities at grass, and good stores are scarce, the best being fattened on their native pastures. They are not only almost the only breed in their own county, but few English counties south of Shropshire are without them; they have done well in Ireland, and in Canada, the United States, South America, and Australia have attained great success. They are not so well qualified for crossing as Shorthorns, but have blended well with that breed, and produced good crosses with Ayrshires and Jerseys, but not with Devons. It has been said that they are not a favourite sort with London butchers, as they require time to ripen, which does not suit a hurrying age. Hence they probably flourished best under the old 
school of graziers, who sometimes kept them to six or seven years old. At all events they are a very fine breed for beef purposes, their meat being particularly tender, juicy, and finegrained. They are seldom kept for dairy purposes, being poor milkers; consequently the calf is nearly always allowed to run with the dam, which accounts for the fact that one seldom sees pure-bred Herefords that are not well grown. The highest price paid for a Hereford was 4,000 guineas for Lord Wilton in I 884 .

\section{Devons.}

The cattle of North Devon can be traced as the peculiar breed of the county from which they take their name from the earliest records. Bradley mentioned the red cattle of Somerset in 1726 , and no doubt there were many in Devonshire. ${ }^{1}$ William Marshall states (1805), and he is supported by subsequent writers, that 'they are of the middle horn class', and in his time so nearly resembled the Herefordshire breed in frame, colour, and horn, as not to be distinguishable from them, except in the greater cleanness of the head and fore-quarters, and their smaller size. Yet they could not have had the white faces and throats of the Herefords, as they have always been famous for their uniformity in coloura fine dark red. ${ }^{2} \mathrm{He}$ also compares them to the cattle of Sussex and the native cattle of Norfolk. ${ }^{3}$ The Devons then differed very much in different parts of the county; those of North Devon taking the lead, being 'nearly what cattle ought to be'. They were, considered as draught animals, the best workers anywhere beyond all comparison, though rather small, for which deficiency they made up in

1 See above, p. 168.

2 Risdon, Survey (1810), Introd. p. viii.

3 Rural Economy of West of England, i. 235. Risdon says of Devonshire: 'As to cattle, no part of the Kingdom is better supplied with beasts of all sorts, whether for profit or pleasure,' those for pleasure being apparently wild ones kept in parks.-Chapple's Revieze of Risdon's Survey, p. 23. 
exertion and agility. As dairy cattle they were not very good, since rearing for the east country graziers had long been the main object of Devon cattle farmers, but as grazing cattle they were excellent.

Vancouver, a few years after this, praised their activity in work and their unrivalled aptitude to fatten, but says they were then declining in their general standard of excellence, and in numbers, owing to the great demand for them from other parts of England, where the buyers (Mr. Coke, who had established a valuable herd of them, and others) spared neither pains nor price to obtain those of the highest excellence.

This danger was clearly perceived by Francis Quartly of Molland, who set to work to remedy it by systematically buying the choicest cows he could procure. As the reputation and perhaps continuance of the Devon breed is due to him more than to any other man, his account of his own efforts on behalf of it is specially valuable. ${ }^{1}$ At the end of the eighteenth century the principal North Devon yeomen were all breeders, and every week you might see in the Molton Market, their natural locality, animals that would now be called choice. There were few cattle shows in those days, and therefore the relative value of animals was not so easily tested. The war prices tempted many farmers to sell their best bulls and cows out of the district, so that good animals were becoming scarce, and the breed generally going back. Mr. Quartly therefore for years bought all the best animals he could find with rare skill and judgement, and continued to improve his stock till he brought it to perfection. About the year 1834 cattle shows began at Exeter, and for the first year or two Mr. Quartly did not compete; then he allowed his nephews to enter in all the classes, and they brought home all the prizes. This lead they kept, and at the Royal Show at Exeter in 1850 their stock obtained nine

${ }^{1}$ R.A.S.E. Journal (Ist ser.), xi. 680. See also ibid. xix. 368, and (2nd ser.) v. $107 ;$ xiv. $663 ; \mathrm{xx} .691$. 
out of the ten prizes for Devons. The Devon Herd-Book was first published in $185 \mathrm{I}$ by Captain T. T. Davy, and a writer in $185^{8}$ says that of twenty-nine prize bulls in the first three volumes twenty-seven were descended from the Quartly bull Forester, and of thirty-four prize cows twentynine from the cow Curly, also of their stock.

Among other famous breeders of Devons contemporary with Quartly were Messrs. Merson, Davy, Michael Thorne, Yapp, Buckingham, the Halses, and George Turner.

In 1829 Moore says, 'The young heifers of North Devon, with their taper legs, the exact symmetry of their form, and their clear coats of dark red, are pictures of elegance.' Their superiority for grazing and draught was proved by the high prices demanded for them, but they were not equally esteemed as dairy animals, ${ }^{1}$ though of late years this reproach has been removed. The ploughing of two acres of fallow land was the common work of four oxen, which, when fattened at five years old, would reach eleven score a quarter.

Since the publication of the Herd-Book, Devons have spread all over the world, to Mexico, Jamaica, Canada, Australia, France, and United States, and the fact that in their original home they have been largely kept by tenant farmers proves them a good rent-paying breed. Yet it cannot be pretended that away from their native country they are as much valued as the Shorthorn and Hereford.

The South Hams breed of South Devon is a distinct variety, though it is believed to be descended from the 'Rubies'1 and apparently has at some time been crossed with the Guernsey; they are good milkers and attain a great size, but the quality of the meat is decidedly inferior to that of North Devon.

From the earliest times the real Devon colour has been red, varying from a dark to a lighter or almost chestnut

${ }^{2}$ R. A.S.E. Journal (3rd ser.), i. 527. 
shade; half a century ago the lighter ones were more numerous than at present, and they are often of richer quality though less hardy than the dark ones.

The Sussex is larger and coarser than the Devon, of a deep brown chestnut colour, very hardy, a beef-producing but not a milk-yielding sort.

Longhorns, ${ }^{1}$ a generation ago nearly extinct, once the favourite cattle of the midlands and portions of the north, are descended from a breed long established in the Craven district of Yorkshire. 'The true Lancashire,' said Young in I770, 'were Longhorns, and in Derbyshire were a bastard sort of Lancashires.' ${ }^{2}$ It was this breed that Bakewell improved, and of late years great efforts, chiefly in Warwickshire and Leicestershire, have been made to revive it.

The Red Polled, or Norfolk Polled, is the only hornless breed of English cattle, and they are good milkers and fatteners.

The Lincoln Red is a small red variety of the Shorthorn.

Many of the Welsh breeds have spread into the adjacent parts of England, and may be classified as North and South Welsh, or Angleseys and Castle Martins; black in colour, and generally with long horns.

The Scottish cattle-the Aberdeen Angus, the Galloways, the Highland breed, and the Ayrshires-are also seen in England, but not so often as the Jerseys and Guernseys from the Channel Islands, while the small Dexters and Kerrys from Ireland are favourites with some English farmers.

\section{SHEEP}

The sheep of the British Isles may be divided into three main classes:-

I. Longwools, containing Leicesters, Border Leicesters, Cotswolds, Lincolns, Kentish, Devon Longwool, South Devon, Wensleydale, and Roscommon.

1 See above, p. $275 \mathrm{n}$.

2 Northern Tour, ii. 126. 
2. Shortwools : the Oxford Downs, Southdowns, Shropshires, Hampshire Downs, Suffolks, Ryelands, Somerset and Dorset Horned, and Clun Forest.

3. Mountain breeds : Cheviots, Blackfaced Mountain, Herdwick, Lonk, Dartmoor, Exmoor, Welsh Mountain, and Limestone.

These are all English except the Border Leicester, Cheviot, and Blackfaced Mountain, which are Scotch; the Welsh Mountain is of course Welsh, and the Roscommon Irish.

1. The Leicesters, the largest and in many respects the most important of British longwool sheep, are the sheep which Bakewell improved so greatly. They are capable of being brought to a great weight, and their long fine wool averages $7 \mathrm{lb}$. to the fleece.

The Border Leicesters are an offshoot of the last named, bred on the Scottish Border, and originating from the flock which George and Matthew Culley in 1767 took from the Tees to the Tweed.

The Cotswolds have been on the Gloucestershire hills for ages, and have long been famous for the length of their fleece, hardiness, and breeding qualities.

The Lincoln is the result of the old native breed of the county improved by Leicester blood. They have larger heads and denser and heavier wool than the Leicesters, averaging 8 to $9 \mathrm{lb}$. to the fleece, but have been known to yield $14 \mathrm{lb}$.

The Kentish or Romney Marsh have long existed in the district whence they obtain their name, but are not much known away from that locality.

The Devon Longwool is a result of the infusion of Leicester blood among the old Bampton stock of Devonshire called Bampton Notts or polled sheep.

The South Devons or South Hams are another local breed, and are a result of the improvement of the South Hams Notts by the Leicester. 
The Wensleydales are descendants of the old Teeswater breed, itself a variety of the old Leicester and improved by the new Leicesters of Culley.

2. Oxford Downs, a modern black-faced breed, now widely spread all over the midland counties, are a mixture of Cotswolds with Hampshire Downs and Southdowns, and originated at the beginning of Queen Victoria's reign, but were not definitely so called till 1857 . This cross of two distinct varieties, the long and the short wool, has approximated to the shortwool type.

The Southdown, formerly Sussex Down, an old breed bred for ages on the chalky soils of the South Downs, is 'perhaps', says Youatt, 'the most valuable breed in the kingdom.' It was to John Ellman of Glynde, at the end of the eighteenth century, that they owe their present perfection, and they have exercised as much influence among the shortwools as the Leicesters among the longwools.

The Shropshire sheep is a descendant of the original Longmynd or old Shropshire sheep, which began to be crossed by the Southdown at the commencement of the nineteenth century. ${ }^{1}$ They were recognized as a distinct breed in 1853 , and since then have become one of the most valued breeds, combining the symmetry and quality of the Southdown with the weight of the Cotswold and the fattening tendency of the Leicester, with a hardier constitution.

The Hampshire Down is another instance of the widespread influence of the Southdown, being the result of crossing that breed with the old Wiltshire sheep, which had long curling horns, and the Berkshire Knott. They are heavier than the Shropshire, and are perhaps more distinguished for early maturity than any other breed.

TheSuffolk is derived from the old horned Norfolk ewe mated with the Southdown, and was first granted its name in 1859.

The Ryeland is a small, hornless, white-faced breed which ${ }^{1}$ R.A.S.E. Journal (1858), p. 42. 
has been in Herefordshire for centuries, but of late years has dwindled in numbers before the advent of the Shropshire.

The Somerset and Dorset Horned is another old breed, preserved in a pure state, much improved in modern times, and very hardy.

The Clun Forest breed of West Shropshire and the adjacent parts of Wales is a mixture of the Ryeland, Shropshire, and Welsh breeds.

3. The Cheviot is found on both sides of the hills of that name, though Northumberland is said to be its original home, and it was improved in the eighteenth century by crossing with the Lincoln.

The Blackfaced Mountain breed is found chiefly in Scotland, but thrives on the bleak grazing lands of the north of England.

The Herdwicks' home is the hills of Cumberland and Westmoreland, where they are hardy enough to fatten on the poor, thin pasture.

The Lonk is the largest mountain breed, belonging to the fells of Yorkshire and Lancashire.

The Dartmoors and Exmoors almost certainly came from one stock, though the former are now the larger, and are the few real survivors of the old forest or mountain breeds of England. The Exmoor is horned, the Dartmoor hornless.

The Welsh Mountain is a small, hardy, soft-woolled breed, their mutton having the best flavour of any sheep, and their wool making the famous Welsh flannel.

The Limestone is little known outside the fells of Westmoreland.

\section{PIGS}

Our pigs may be roughly divided into white, black, and red; the first comprising the Large, Middle, and Small Whites, formerly called Yorkshires; the second the Small Black (Suffolk or Essex), the Large Black only recently recognized, but apparently very ancient, and the Berkshire, which often has white marks on face, legs, or tail. The red is the Tamworth, one of the oldest breeds, its skin being red with dark spots. 


\section{APPENDIX I}

\section{AVERAGE PRICES FROM 1259 TO $1700^{1}$}

CORN PER QUARTER.

$\begin{array}{lrrrrr} & \text { WHEAT. } & \text { BARLEY. } & \text { OATS. } & \text { RYE. } & \text { BEANS. } \\ 1259-1400 & 5 s .10 \frac{3}{4} d . & 4 s .3 \frac{3}{4} d . & 2 s .5 \frac{3}{4} d . & 4 s .4 \frac{7}{8} d . & 4 s .3 \frac{1}{2} d . \\ 1401-1540 & 5 s .11 \frac{3}{4} d . & 3 s .8 \frac{3}{4} d . & 2 s .2 \frac{1}{4} d . & 4 s .7 \frac{3}{4} d . & 3 s .9 \frac{1}{4} d . \\ 1541-82 & 13 s .10 \frac{1}{2} d . & 8 s .5 \frac{3}{4} d . & 5 s .5 \frac{1}{2} d . & - & 9 s_{0} 1 \frac{1}{2} d . \\ 1583-1700 & 39 s .0 \frac{1}{2} d . & 21 s .4 d . & 13 s .10 d . & - & 22 s .3 \frac{1}{4} d .\end{array}$

\section{LIVE STOCK.}

OXEN. COWS. CART ${ }_{\text {HORSES. }}^{2}$ SHEEP. LAMBS. $\begin{gathered}\text { PIGS } \\ \text { (GROWN). BOARS. }\end{gathered}$

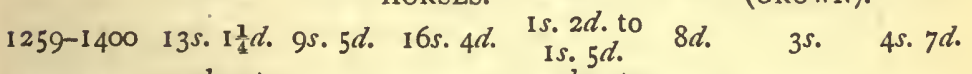

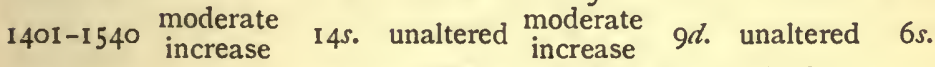

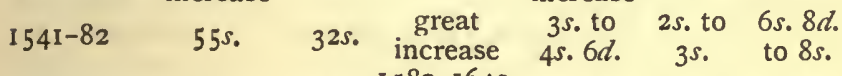
1583-1700 100s. 6os. $\begin{aligned} & 1580-1640 \\ & 1640-1700 \\ & £ 8 \text { to } f 15\end{aligned}$ Ios. $7 \pi \quad$ great increase POULTRY AND EGGS.

\begin{tabular}{|c|c|c|c|c|}
\hline I 259-1 & $\begin{array}{c}\text { HENS. } \\
1 \frac{5}{8} d .\end{array}$ & $\begin{array}{c}\text { DUCKS. } \\
2 \pi .\end{array}$ & $\begin{array}{c}\text { GEESE. } \\
3 \overline{8} d .\end{array}$ & $\begin{array}{l}\text { EGGS. } \\
4 \frac{1}{2} d \cdot \text { per } 120\end{array}$ \\
\hline $140 \mathrm{I}-\mathrm{I} 540$ & $2 \frac{1}{4} d$. & $2 \frac{1}{4} d$ & $44_{4}^{3} d$. & $6 \frac{1}{2} d$. \\
\hline & $3^{3} d$ & $4 \frac{3}{4} d$. & IOd. & $7 \frac{1}{2} d$ \\
\hline $583-1700$ & $8 d_{.}-1 s$. & $9 \frac{1}{4} d$. & $2 s$. & $3 s .3 d$. \\
\hline
\end{tabular}

WOOL. CHEESE. BUTTER. HAY. HOPS. Per lb. Per load. Per cut. $1259-1400 \quad 3 \frac{5}{7} d . \quad 4 \frac{1}{2} d$. per $7 \mathrm{lb} . \quad 4 \frac{3}{4} d \cdot$ per $7 \mathrm{lb}$. I $40 \mathrm{I}-\mathrm{I} 540 \quad 3 \frac{5}{7} d . \quad \frac{1}{2} d$. per lb. $\quad \mathrm{I} d$. per lb. unaltered $145.0 \frac{1}{2} d$.

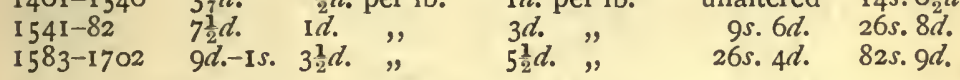

1 Summarized from Thorold Rogers' prices in his History of Agriculture and Prices, with some alterations.

${ }^{2}$ Affri, 13s. $5 d$., cart horses, 19s. 4d. A good saddle horse about 1300 was worth $£ 5$. By 1580 it was worth $£ 10$ to $£ 15$, by $1700 £ 20$ to $£ 25$. 
LABOUR.

Reaping wheat Reaping oats Mowing Labourer per day per acre.

without food.

$126 I-1350$
$135 I-1400$
$1401-1540$
$1541-82$
$1583-1640$
$1640-1700$

$5 \frac{5}{8} d$.
$8 \frac{1}{2} d$.
$9 \frac{3}{4} d$
$=1$
-

per acre.

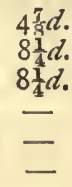

per acre.

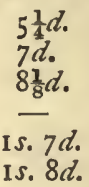

PRICE OF LAND PER ACRE.
To Rent.

Arable.

$4 d .-6 d$.

$6 d$.

$6 d$.

slight increase

great increase

5 s.
Grass.

Is. - -2s.

25.

$2 s$.

$8 s$.

Ios.
To Buy.

I2 years' purchase

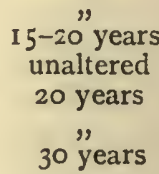

\section{APPENDIX II}

TABLE SHOWING EXPORTS AND IMPORTS OF WHEAT AND FLOUR FROM AND INTO ENGLAND, UNIMPORTANT YEARS OMITTED
England.

Exports. Imports.

Quarters.

1697

1703

1717

1728

1733

1750
14,699

I 66,615

22,954

3,817

427,199

947,602
Great Britain.

1757

1758

I 76 I

I 767

1770

I775
Quarters.
II, 545

9,234

44I,956

5,07 I

75,449

91,037

400
50
none
74,574
7
279

141,562
20,353
none
497,905
34
560,988

Exports. Quarters.

1776

1780

I 786

1787

I789

I79I

1796

I 801

I 808

1810

1815

1825

I 837

I 839

1842
210,664

224,059

205,466

I 20,536

140,0I 4

70,626

24,679

28,406

98,005

75,785

227,947

38,796

308,420

42,512

68,047
$2 d$.

$3 d$.

$4 d$.

$6 \frac{1}{2} d$.

$8 \frac{1}{2} d$. 
The above figures are taken from $\mathrm{M}^{\mathrm{C}}$ Culloch's Commercial Dictionary, I 847 , p. 438 , and agree roughly with those given by McPherson, Annals of Commerce, iii. 674, and iv. 216 and 532.

After I842, exports played a very small part, and imports continued to increase ; in 1847, 4,612,110 quarters of wheat and flour came in ; and the following figures show their growth in recent times:-

Average of ANNUAL Imports of Wheat aNd Flour in cwts.

$\begin{array}{llllr}\text { 1 } 861-5 & \ldots & \ldots & \ldots & 34,651,549 \\ 1866-70 & \ldots & \ldots & \ldots & 37,273,678 \\ 1871-5 & \ldots & \ldots & \ldots & 50,495,127 \\ 1876-80 & \ldots & \ldots & \ldots & 63,309,874 \\ 1881-5 & \ldots & \ldots & \ldots & 77,285,881 \\ 1886-90 & \ldots & \ldots & \ldots & 77,794,380 \\ 1891-5 & \ldots & \ldots & \ldots & 96,582,863 \\ 1896-1900 & \ldots & \ldots & \ldots & 95,956,376 \\ 1901-5 & \ldots & \ldots & \ldots & 111,638,817\end{array}$

With regard to the exports and imports of all kinds of corn, large quantities were exported in the first half of the eighteenth century. In I733, 800,000 quarters were sent to France, Portugal, Spain, and Italy, ${ }^{1}$ and exports reached their maximum in 1750 with $1,667,778$ quarters, but by 1760 had decreased to 600,000 , and after that fell considerably; in 1771 , for instance, the first year of the corn register, they only amounted to 81,665 quarters, whereas imports were 203,122. The figures of the imports were swollen by the large quantities of oats which came into England at this time. The following years are typical of the fluctuations in the trade :-

$\begin{array}{lcc} & \text { Exports. } & \text { Imports. } \\ 1774 & 47,961 & 803,844 \\ 1776 & 376,249 & 444,121 \\ 1780 & 400,408 & 219,093 \\ 1782 & 278,955 & 133,663 \\ 1783 & \text { I04,274 } & 852,389 \\ 1784-8 & \text { large excess of imports, mainly oats } \\ \text { 1789 } & 652,764 & 478,426\end{array}$

the last year when exports of all kinds of corn exceeded imports. ${ }^{2}$

To sum up, according to these figures, England's exports of wheat regularly exceeded her imports from 1697 until 1757 , with the exception of the years 1728-9; then they fluctuated till 1789, the last year in which exports of wheat exceeded imports, and as the same year is the last time when our exports of all kinds of corn exceeded our imports, England at that date ceased to be an exporting country. ${ }^{3}$

1 McPherson, Annals of Commerce, iii. 198.

2 Ibid. iii. 674 ; iv. $216,532$.

3 The excess of exports of wheat in 1808 was accidentally due to the requirements of the army in Spain. 


\section{APPENDIX III}

AVERAGE PRICES PER IMPERIAL QUARTER OF BRITISH CORN IN ENGLAND AND WALES, IN EACH YEAR FROM 1771 TO 1907 INCLUSIVE, ACCORDING TO THE RETURNS OF THE BOARD OF AGRICULTURE

YEARS.

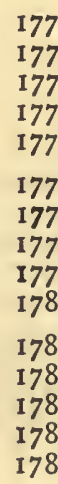

1786

1787

1788

1789

I790

I79I

1792

1793

1794

1795

1796

1797

1798

1799

1800

1801

1802

1803

1804

1805
WHEAT.

s. $d$.

487

523

527

543

4910

394

46 II

$\begin{array}{ll}43 & 3 \\ 34 & 8\end{array}$

36
36

460

493

543

504

43 I

400

425

464

529

549

487

43 o

493

523

752

$\begin{array}{ll}78 & 7\end{array}$

539

5110

690

II 10

II9 6

6910

5810

623

899
BARLEY.

s. $d$.

265

26 I

292

294

269

209

21 I

234

201

I7 6

178

232

$\begin{array}{ll}31 & 3 \\ 28 & 8\end{array}$

249

25 I

234

228

236

263

2610

277

$3 I I$

319

375

354

272

290

$\begin{array}{ll}36 & 2\end{array}$

5910

686

334

254

310

$\begin{array}{ll}31 & 6\end{array}$
OATS.

s. $d$.

172

168

178

184

170

155

16 I

I5 7

145

I 32

141

I5 7

205

1810

178

186

172

16 I

166

I9 5

18 I

169

206

2I. 3

245

2 I 10

163

195

276

394

37 o

204

216

243

$\begin{array}{ll}24 & 3 \\ 28 & 4\end{array}$ 


\begin{tabular}{|c|c|c|c|c|c|c|c|}
\hline EARS. & & $\begin{array}{l}\text { WHEAT } \\
s . d \text {. }\end{array}$ & & $\begin{array}{c}\text { BARI } \\
s .\end{array}$ & LEY. & & $\begin{array}{l}\text { OATS. } \\
s . \quad d .\end{array}$ \\
\hline 1806 & $\ldots$ & 791 & $\ldots$ & 38 & 8 & $\ldots$ & $\begin{array}{ll}s_{2} & a_{0}\end{array}$ \\
\hline 1807 & $\ldots$ & $\begin{array}{ll}75 & 4\end{array}$ & $\ldots$ & 39 & 4 & $\ldots$ & 284 \\
\hline 1808 & $\ldots$ & $\begin{array}{ll}81 & 4\end{array}$ & $\ldots$ & 43 & 5 & $\ldots$ & 334 \\
\hline 1809 & $\ldots$ & $97 \quad 4$ & $\ldots$ & 47 & o & $\ldots$ & $3 \mathrm{I} 5$ \\
\hline 1810 & $\ldots$ & 1065 & $\ldots$ & 48 & I & $\ldots$ & 287 \\
\hline 1811 & $\ldots$ & $95 \quad 3$ & $\ldots$ & 42 & 3 & $\ldots$ & $27 \quad 7$ \\
\hline 1812 & $\ldots$ & 1266 & $\ldots$ & 66 & 9 & $\ldots$ & 446 \\
\hline 1813 & $\ldots$ & 1099 & $\ldots$ & $5^{8}$ & 6 & $\ldots$ & 386 \\
\hline 1814 & $\ldots$ & 744 & $\ldots$ & 37 & 4 & $\ldots$ & 258 \\
\hline 1815 & $\ldots$ & 657 & $\ldots$ & 30 & 3 & $\ldots$ & 237 \\
\hline 1816 & $\ldots$ & $\begin{array}{ll}78 & 6\end{array}$ & $\ldots$ & 331 & I I & $\ldots$ & $27 \quad 2$ \\
\hline 1817 & $\cdots$ & 96 II & $\ldots$ & 49 & 4 & $\ldots$ & 325 \\
\hline 1818 & $\ldots$ & $86 \quad 3$ & $\ldots$ & 53 & 10 & $\ldots$ & 325 \\
\hline 1819 & $\ldots$ & 746 & $\ldots$ & 45 & 9 & $\ldots$ & 282 \\
\hline 1820 & $\ldots$ & 6710 & $\ldots$ & 331 & Io & $\ldots$ & 242 \\
\hline 1821 & $\ldots$ & 56 I & $\ldots$ & 26 & o & $\ldots$ & 196 \\
\hline 1822 & $\ldots$ & $44 \quad 7$ & $\ldots$ & 21 & 10 & $\ldots$ & $\begin{array}{ll}18 & 1\end{array}$ \\
\hline 1823 & $\ldots$ & 534 & $\ldots$ & 31 & 6 & $\ldots$ & 22 II \\
\hline 1824 & $\ldots$ & $63 \mathrm{II}$ & $\ldots$ & 36 & 4 & $\ldots$ & 2410 \\
\hline 1825 & $\ldots$ & 686 & $\ldots$ & 40 & 0 & $\ldots$ & 258 \\
\hline 1826 & $\ldots$ & $\begin{array}{rr}58 & 8 \\
-8 & 6\end{array}$ & $\ldots$ & 34 & 4 & $\ldots$ & $\begin{array}{ll}26 & 8\end{array}$ \\
\hline 1827 & $\cdots$ & $\begin{array}{ll}58 & 6\end{array}$ & $\cdots$ & 37 & 7 & $\cdots$ & $\begin{array}{ll}28 & 2\end{array}$ \\
\hline 1828 & $\cdots$ & 605 & $\ldots$ & 32 & 10 & $\cdots$ & 226 \\
\hline 1829 & $\ldots$ & 663 & $\ldots$ & 32 & 6 & $\ldots$ & 229 \\
\hline 1830 & $\ldots$ & 643 & $\ldots$ & 32 & 7 & $\ldots$ & 245 \\
\hline 1831 & $\ldots$ & 664 & $\ldots$ & 38 & o & $\ldots$ & 254 \\
\hline 1832 & $\ldots$ & 588 & $\ldots$ & 33 & I & $\ldots$ & 205 \\
\hline 1833 & $\ldots$ & 52 II & $\ldots$ & 27 & 6 & $\ldots$ & 185 \\
\hline 1834 & $\ldots$ & $46 \quad 2$ & $\ldots$ & 29 & 0 & $\ldots$ & 20 II \\
\hline 1835 & $\ldots$ & 394 & $\ldots$ & 291 & I I & $\ldots$ & 220 \\
\hline 1836 & $\ldots$ & $\begin{array}{ll}48 & 6\end{array}$ & $\ldots$ & 32 & 10 & $\ldots$ & 231 \\
\hline I837 & $\ldots$ & 5510 & $\ldots$ & 30 & 4 & $\ldots$ & 231 \\
\hline 1838 & $\ldots$ & 647 & $\ldots$ & 31 & 5 & $\ldots$ & 225 \\
\hline 1839 & $\ldots$ & 708 & $\ldots$ & 39 & 6 & $\ldots$ & $25 \mathrm{II}$ \\
\hline 1840 & $\ldots$ & 654 & $\ldots$ & 36 & 5 & $\ldots$ & 258 \\
\hline I84I & $\ldots$ & $\begin{array}{ll}64 \quad 4\end{array}$ & $\ldots$ & 32 & 10 & $\ldots$ & 225 \\
\hline 1842 & $\ldots$ & $\begin{array}{ll}57 & 3\end{array}$ & $\ldots$ & 27 & 6 & $\ldots$ & 193 \\
\hline 1843 & $\ldots$ & 501 & $\ldots$ & 29 & 6 & $\ldots$ & 184 \\
\hline 1844 & $\ldots$ & $\begin{array}{ll}51 & 3\end{array}$ & $\ldots$ & 33 & 8 & $\ldots$ & 207 \\
\hline 1845 & $\ldots$ & 5010 & $\ldots$ & $3 \mathrm{I}$ & 8 & $\ldots$ & 226 \\
\hline 1846 & $\ldots$ & 548 & $\ldots$ & 32 & 8 & $\ldots$ & 238 \\
\hline 1847 & $\ldots$ & 699 & $\ldots$ & 44 & 2 & $\ldots$ & 288 \\
\hline 1848 & $\ldots$ & 506 & $\ldots$ & $3 \mathrm{I}$ & 6 & $\ldots$ & 206 \\
\hline 1849 & $\ldots$ & $44 \quad 3$ & $\ldots$ & 27 & 9 & $\ldots$ & 176 \\
\hline 1850 & $\ldots$ & 403 & $\ldots$ & 23 & 5 & $\ldots$ & 165 \\
\hline
\end{tabular}


YEARS.

1851

1852

1853

1854

1855

1856

1857

1858

1859

1860

$186 \mathrm{I}$

1862

1863

I 864

I 865

I 866

I 867

1868

1869

1870

1871

1872

1873

I 874

1875

1876

I 877

1878

1879

1880

I $88 \mathrm{I}$

I 882

1883

1884

I 885

1886

I 887

I 888

I 889

I 890

1891

I 892

I 893

1894

1895
WHEAT.

s. $d$.

$38 \quad 6$

409

$53 \quad 3$

$\begin{array}{ll}72 & 5 \\ 74 & 8\end{array}$

692

564

442

439

533

554

$55 \quad 5$

449

402

4I 10

49 II

645

639

$48 \quad 2$

46 II

$\begin{array}{ll}56 & 8\end{array}$

57

$58 \quad 8$

559

452

462

$56 \quad 9$

465

43 I0

$44 \quad 4$

$45 \quad 4$

45 I

417

358

3210

310

326

3110

299

3I II

37 o

303

264

2210

23 I
BARLEY.

OATS.

s. $d$.

s. $d$.

$\begin{array}{ll}24 & 9 \\ 28 & 6\end{array}$

332

36 o

349

4 I I

42 I

348

336

367

36 I

35 I

33 II

29 II

299

375

$40 \quad 0$

43 o

395

347

$36 \quad 2$

$37 \quad 4$

405

44 II

$38 \quad 5$

352

398

402

34 ○

33 I

3 I II

3I 2

3110

308

30 I

267

254

2710

2510

288

$28 \quad 2$

262

257

246

2I II
187

I 9 I

210

27 II

275

252

250

246

232

245

239

227

212

20 I

2110

247

260

28 I

260

2210

252

232

255

28 IO

$28 \quad 8$

263

25 II

244

2 I 9

23 I

2I 9

21 IO

215

203

207

190

163

169

179

I8 7

200

1910

189

17 I
146 


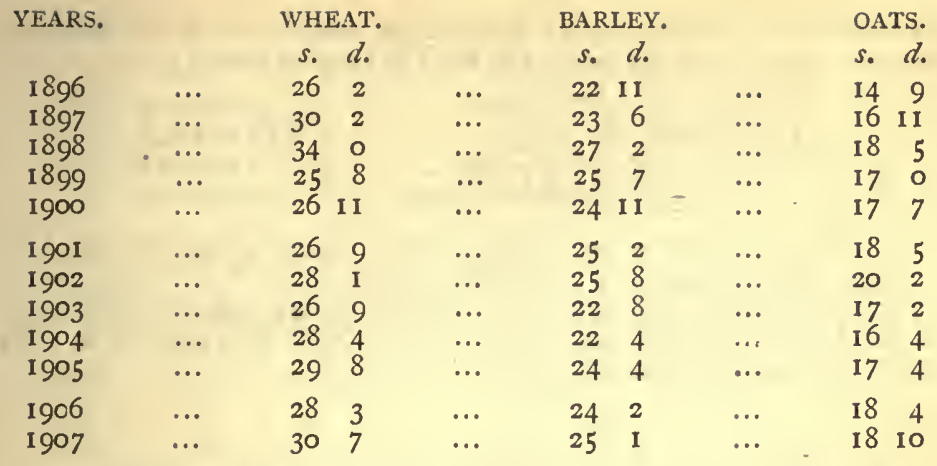

\section{APPENDIX IV}

\section{MISCELLANEOUS INFORMATION}

GREGORY KING, at the end of the seventeenth century, estimated the acreage of England and Wales at 39,000,000-not at all a bad estimate, the area, excluding water, according to the Board of Agriculture Returns of 1907 , being $37,130,344$. The different estimates by Grew, Templeman, Petty, Young, Halley, Middleton, and others varied between $31,648,000$ and $46,916,000$ acres. The last, that of Arthur Young, was actually adopted by Pitt for his estimate of the income-tax. ${ }^{1}$

Caird in $1850^{2}$ estimated the cultivated lands of England at $27,000,000$ acres (in 1907 they were $24,585,455$ acres), cultivated thus :-

$$
\begin{array}{lccccc}
\text { Permanent grass } & \ldots & \ldots & \ldots & 13,333,000 \\
\text { Arable } . . & \ldots & \ldots & \ldots & \ldots & 13,667,000
\end{array}
$$

the latter being divided as follows :-

Acres. Bushels, Produce, per acre. quarters.

$\begin{array}{lcccccr}\text { Wheat } & \ldots & \ldots & \ldots & 3,416,750 & 27 & 11,531,531 \\ \text { Barley } & \ldots & \ldots & \ldots & \text { I,416,750 } & 38 & 6,729,562 \\ \text { Oats and rye } \ldots & \ldots & \ldots & 2,000,000 & 44 & 11,000,000 \\ \text { Clover and seeds } & \ldots & \ldots & 2,277,750 & & \\ \text { Beans and peas } & \ldots & \ldots & 1,139,000 & 30 & 4,271,250 \\ \text { Turnips, mangolds, } & \text { and } & & & \\ \text { potatoes } \ldots & \ldots & \ldots & 2,116,750 & & \\ \text { Rape and fallow } & \ldots & \ldots & 1,300,000 & & \end{array}$

1 C. Wren Hoskyns, Pamphlet on Agricultural Statistics, p. 19.

${ }^{2}$ English Agriculture in 1850-1, p. 521. Cf. above, p. 331.

CURTLER

A a 
Davenant, at the end of the seventeenth century, made the following estimate showing the importance of wool in English trade ${ }^{1}$ :-

$\begin{array}{ccr}\text { Annual income of England } & \ldots & £ 43,000,000 \\ \text { Yearly rent of land ... } \ldots & \ldots & 10,000, \infty 00 \\ \text { Value of wool shorn yearly... } & \ldots & 2,000,000 \\ ", \quad \text { woollen manufactures } & \ldots & 10,000,000\end{array}$

Thus the rents of land formed nearly one-fourth the total income of the country, and wool paid one-fifth of the rents. ${ }^{2}$

In the eighteenth century a great quantity of wool was smuggled out of England in defiance of the law; in the space of four months in 1754, 4,000 tods was 'run' into Boulogne.

Foreign and Colonial WoOl imported into England.

\begin{tabular}{rrr|rrr} 
& & \multicolumn{1}{c|}{$1 \mathrm{~b}}$. & & \multicolumn{1}{c}{$1 \mathrm{~b}}$. \\
1766 & $\ldots$ & $1,926,000$ & 1820 & $\ldots$ & $9,775,000$ \\
1771 & $\ldots$ & $1,829,000$ & 1830 & $\ldots$ & $32,305,000$ \\
1780 & $\ldots$ & 323,000 & 1840 & $\ldots$ & $49,436,000$ \\
1790 & $\ldots$ & $2,582,000$ & 1850 & $\ldots$ & $74,326,000$ \\
1800 & $\ldots$ & $8,609,000$ & 1855 & $\ldots$ & $99,300,000$ \\
1810 & $\ldots$ & $10,914,000$ & 1857 & $\ldots$ & $127,390,000$
\end{tabular}

Prices of Labour in SURRey in 1780.5

Day labourer, per day, in winter

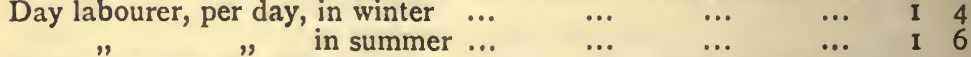

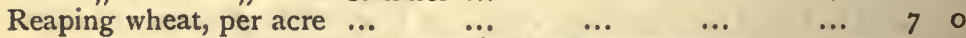

" $\quad$ " and according to the crop up to $\quad \ldots \quad 12 \quad 0$

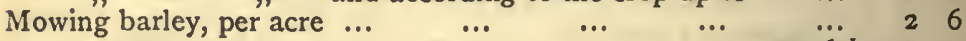

$\begin{array}{llllllll} & \text { oats, } \quad " \quad \ldots & \ldots & \ldots & \ldots & \text { Is. } 6 \text {. } 6 \text {. to } 2 & 0\end{array}$

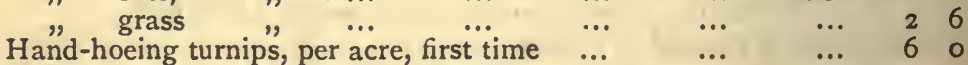

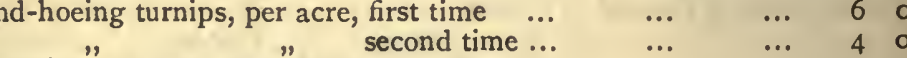

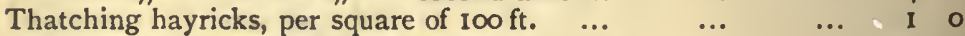

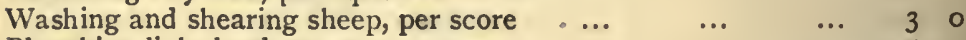

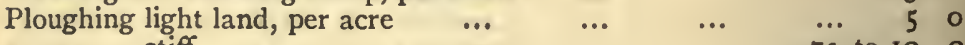

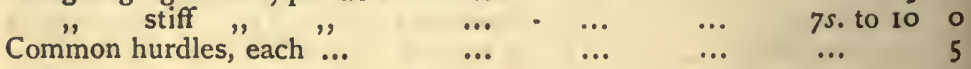

1 Smith, Memoirs of Wool, i. 157.

2 In 1908 the rental of agricultural land was $3 \frac{1}{2}$ per cent. of the total income of the country. See The Times, May 13, 1909.

Ibid. ii. 264.

- Cunningham, Industry and Commerce, ii. 693. Cf. above, p. 328.

- Trusler, Practical Husbandry, p. 153. 


\section{OCCUPIERS OF LAND.}

In 1816 there were said to be 589,374 occupiers of land in Great Britain ${ }^{1}$

With incomes under $f 50$

Between $£ 50$ and $£$ I 50

Over $£ 150$

$\begin{array}{lllr}\ldots & \cdots & \cdots & 114,778 \\ \cdots & \cdots & \cdots & 432,534 \\ \cdots & \cdots & \cdots & 42,062\end{array}$

In 1907 there were 510,954 occupiers of one acre and more.

589,374

Mulhall's Calculation of Average annual Wages in England. Bailiff. Shepherd. Labourer. Woman. Boy.

$\begin{array}{rrrrrr}1800 & £ 20 & £ 16 & £ 12 & £ 8 & £ 6 \\ 1850 & 40 & 25 & 20 & 10 & 8 \\ 1880 & 52 & 36 & 30 & 15 & 10\end{array}$

The average annual cost of living of an agricultural family of five was in $1823 £ 31$, in $1883 £ 37$.

Comparative Statement by A. Young of Prices and Wages in

ENGLAND FROM I200 TO I8IO ON THE PRINCIPLE OF REPRESENTING FACTS IN 1810 BY THE NUMBER 20, AND THE FACTS OF THE PRECEDING PERIOdS BY THE PROPORTION BORNE BY THEM TO THAT NUMBER.

$\begin{array}{lccccc}\text { Periods. } & \text { Wheat. } & \text { Meat. } & \text { Wool. } & \begin{array}{c}\text { Labourers' } \\ \text { wages. }\end{array} & \text { Horses. } \\ 1200-99 & 5 \frac{1}{2} & \ldots & \ldots & 3 \frac{1}{2} & \ldots \\ 1300-99 & 6 \frac{1}{4} & \ldots & \ldots & 4 \frac{3}{4} & \ldots \\ 1400-99 & 3 & \ldots & \ldots & 5 \frac{1}{2} & \ldots \\ 1500-99 & 6 & \ldots & \ldots & 5 \frac{1}{2} & \ldots \\ 1600-99 & 9 \frac{1}{4} & \ldots & \ldots & 8 & \ldots \\ 1700-66 & 7 \frac{3}{4} & 7 \frac{1}{2} & 12 & 10 & 15 \frac{3}{4} \\ 1767-89 & 11 & 11 \frac{1}{2} & 15 \frac{1}{3} & 12 \frac{1}{2} & 17 \frac{1}{4} \\ 1790-1803 & 13 & 16 \frac{1}{2} & 16 \frac{1}{6} & 16 \frac{3}{4} & 19 \frac{1}{2} \\ 1804-10 & 20 & 20 & 20 & 20 & 20\end{array}$

Thus wheat in 1804-10 had risen 233 per cent. since the sixteenth century.

THE LABOURER'S. WAGES.

The following table, published by Mr. Barton in $1817,{ }^{2}$ shows the depreciation of the labourer's wages in purchasing power between 1742 and 1808 :-

\begin{tabular}{|c|c|c|c|}
\hline Period. & $\begin{array}{c}\text { Weekly } \\
\text { pay. } \\
\text { s. d. }\end{array}$ & $\begin{array}{c}\text { Price of } \\
\text { wheat. } \\
s . d .\end{array}$ & $\begin{array}{l}\text { Wages in } \\
\text { pints of } \\
\text { bread. }\end{array}$ \\
\hline 1742 & 60 & 300 & 102 \\
\hline 1761 & 76 & 426 & 90 \\
\hline 1780 & 80 & 512 & 80 \\
\hline 1795 & 90 & 708 & 65 \\
\hline & II 0 & 868 & 60 \\
\hline
\end{tabular}

1 Farmer's Magazine (1817), p. 6. Statistics at this date, however, must be taken with caution. They were usually estimates. Cf. above, p. 334, for holdings in England.

2 Parliamentary Reports, Commissioners (I88I), xvi. 305. 
In answer to inquiries sent by the Poor Law Commissioners in 1834 to 900 parishes in England the average weekly wages of labourers werein summer,

in winter,

$\begin{array}{crr}\text { in } 254 \text { parishes, with beer or cider } & s . & d . \\ 522 \quad \text { without beer or cider } & \text { 10 } & 4 \frac{3}{4} \\ 5 \frac{1}{2}\end{array}$

$$
\begin{array}{rlll}
\text { in } 200 \quad & \text { with beer or cider } & 9 & 27 \\
544 \quad & \text { without beer or cider } & 9 & \text { I I } \frac{3}{4}
\end{array}
$$

The annual average inclusive earnings of the labourer $£$ s. $d$.

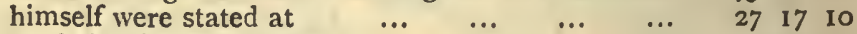

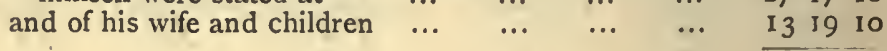

It will thus be seen that the wife and children provided a third of the income. The majority of the parishes said the labourer could maintain his family on these wages.

Here is the weekly budget of a labourer with an average family in $1880^{1}:-$

Cr. s. $d$.

\begin{tabular}{|c|c|c|c|c|c|c|c|c|c|c|}
\hline Wages & $\cdots$ & $\cdots$ & ... & 15 & 0 & Rent & $\cdots$ & $\cdots$ & $\ldots$ & I \\
\hline Garden & $\ldots$ & $\ldots$ & $\ldots$ & I & 6 & Bread & $\ldots$ & $\ldots$ & $\ldots$ & 6 \\
\hline Extras & $\ldots$ & $\ldots$ & $\ldots$ & I & 0 & Bacon & $\ldots$ & $\cdots$ & $\ldots$ & 2 \\
\hline & & ( & & & & Tea and & sugar & $\ldots$ & $\ldots$ & I \\
\hline 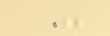 & & & & & & Cheese & $\cdots$ & $\cdots$ & $\cdots$ & I \\
\hline & & te & & & & Butter & ... & $\cdots$ & $\cdots$ & I \\
\hline & & & & & & Fuel & $\cdots$ & ... & $\cdots$ & I \\
\hline & & & & & & Candles & and so & & $\ldots$ & o \\
\hline te & & & & & & Clothes & $\cdots$ & $\cdots$ & $\cdots$ & 1 \\
\hline te & & & & & & Schooling & $g \cdots$ & $\cdots$ & $\cdots$ & o \\
\hline ter & & & & & & Sundries & $\cdots$ & .. & $\cdots$ & 0 \\
\hline & & & & 17 & 6 & & & & & 18 \\
\hline
\end{tabular}

There is no fresh meat, and it is hard to say where any economy could be practised.

CONTRACT PRICES OF BUtCher's MEAT PER CWT. AT GREENWICH HOSPITAL, I730-1842.2

\begin{tabular}{|c|c|c|c|c|c|c|c|c|}
\hline & $£ s$ & $d$. & & $s$. & $d$. & & & s. \\
\hline 1730 & I 5 & 8 & 1790 & 16 & 10 & 1825 & 2 & 19 \\
\hline 1740 & 18 & 0 & 1800 & 4 & 4 & 1830 & 2 & 3 \\
\hline 1750 & 16 & 6 & 1810 & 12 & o & 1835 & 2 & 0 \\
\hline 1760 & I II & 6 & 1815 & 8 & 0 & 1840 & 2 & 14 \\
\hline 1770 & I 8 & 6 & 1820 & 10 & 4 & 1842 & 2 & 12 \\
\hline 8780 & I 12 & 6 & & & & & & \\
\hline
\end{tabular}

1 Parliamentary Reports, Commissioners (188I), xvi. 310.

${ }^{2} \mathrm{M}^{\circ} \mathrm{Culloch}$, Commercial Dictionary (1852), p. 271. 


\section{INDEX}

A

Abbot's Ripton, 72 .

Aberdeen Angus cattle, 288, 343 .

Accounts, keeping, 29, 49.

Accumulation of estates, I 23.

Acre, 2 ; tenantry, 253.

Advantages of large farms, 202.

Affer, the, 35 .

Agricultural Holdings Acts, 283, 296, 299-303.

Agricultural revolution, the, of eighteenth century, $\mathbf{1 6 2}$.

Agriculture, state of, 28, 38 , I I I, I I 3 , I I5, I $23,132,160,162$, I92, 204, 2 I I, 22 I , 229, 244, 245, 250,265 , $267,274,287,305$; seventeenth-century writers on, 127; state of, in eighteenth century, $162,192,22 \mathrm{r}$, 229 ; nineteenth, 244, 245, 262-70, $27 \mathrm{I}, 287$.

Aitchison, 237 .

Akermanni, I 3 .

Alderney cattle, 233.

Ale, Io.

Allotments, 196, 230, 253, 255 n., 31 5-7. Allowance system, 237.

Allowances, parish, $238,24 \mathrm{I}, 257,284$. Almaine, corn from, 20.

Almonds, 93, 136 .

Amalgamation of farms, $29,46,47,95$, I I 9, I 20, I 62, 202, 258, 3 I $\%$.

America, gold discoveries in, 287 ; imports from, 262, 293, 323-4.

Ancaster, Earl of, estate of, $32 \mathrm{r}$.

Andover, 39.

Anti-Corn Law League, 28 o.

Apples, I 5, 65, 93, 129 , I 30, I 31 , 1 35-6, I 43, I 7 I, I 86-9, 329, 332. (See Prices.) Apprentices, 108.

Apricots, 93, I36.

Arable district of England (1 893), $306 \mathrm{n}$. Arable fields, I, 2, 4, 16, 73 .

Arable land, 56, 99, 100, 195 ; amount of, in 1688, 155; decrease of, 59 ; extent of, in Domesday, 19; in 1770 , 199 ; in 1850,353 ; in 1877 and 1907 , 332 ; preponderance of, 25,30 ; produce of, in 1688, I55; suffers more than grass, $248,266,281,285,286$, 306 ; value of, I9, 40, 58, I I 5-7, I 39 . Arch, Joseph, 290-2.

Ardley, Inquisition of, 9.

Argentina, imports from, 324 .

Arley, Upper, wine made at, 145 .

Artificial grasses, see Clover, improve commons, I 66.

Ash timber, value of, I37.

Assize of beer, I3, I4 n.

Association, British, 336 .

Average crops of corn (1 770), 197. (See under Wheat, Oats, Barley, \&c.)

Average size of farms in $1768,202$.

Averagium, 10.

Australia, gold discoveries in, 287 ; imports from, 324; sheep introduced into, 328 ; wool from, 328 .

Axholme, I 23, 260, 31 I, 3 I8.

Ayrshires, 339, 343 .

\section{B}

Bacon, Lord, 322.

Bacon, 'the necessary meate' of the labourer, . I02, 140; price of, see Prices.

Badger, a corn dealer, I 34 .

Bailiff, I2, 29, 49, 5I, 6r, 7I, 103, I09, I Io, I 37, I 39,355 .

Bakewell, 146, 163, 7, 214-7, 226, 233 , 343,344 .

Balance sheet, estate, 307 ; farm, in 1805 , 247 ; in 1888,309 .

Balks, 3 .

Ball, John, 60.

Banbury cheese, I 73 .

Bank Restriction Act, 239, 240, 263.

Barking Nunnery, vineyard at, I44.

Barley, 20, 33, 36, 65, 91 , $124,1_{35}, 1_{4}$ 2, I $55,182,227,33 \mathrm{I}-2,353$; cost of, per acre, 198 ; produce, per acre, $165 \mathrm{n}$., 1 97-8; profit on, I 79, I80. (See Prices.)

Barns, size of, 5 I.

Barren years at end of seventeenth century, I I $5, I_{57}$.

Basic slag, 304 .

Bassingthorpe, I03.

Bates, Thomas, 274, 338 . 
Bath, wine made at, I 45 .

Beale, John, I28, 130.

Beans, I $7,33,49,124,155,187,201$, $262,33 \mathrm{I}-2,353$; cost of growing, 199; profit on, 180. (See Prices.)

Bedford, Duke of, 225, 318, 32 I.

Bedfordshire, 3 , I 8, 79, I 20, I 23, 238, 306.

Beef, price of, see Prices.

Beer, 36, 329.

Belgium, live stock in, 334 ; wheat crops in, $332 \mathrm{n}$.

Belvoir estate, II $\mathbf{5}, 286$.

Berkeley estates, 3,27 n., 35 n., 48, 56, $64,74,75$.

Berkshire, I04, I 75, 237, 284, 286, 306 n.

Berkshire Knotts, 345 ; pigs, 346.

Berlin decrees, 242.

Best, Henry, accounts of, i 38-40.

Bideford, 262.

Biggleswade, 3 I 8.

Birds eating fruit, 129.

Black Death, 27, 4I-3, 59, 75 .

Black Year, the, 294.

Blight, Hop, I 50.

Blyth, I I 3, I 27, I $37, I_{2}$.

Board of Agriculture, 192, 193, 214 , 229-33, 255; (Government), 290.

Bones for manure, I 54-5, $273,275-6$, 299.

Booth, Thomas, 337-8.

Bordarii, 8, I I.

Boston, 308, 318, 327.

Boys' wages, 206.

Bradley, I 52, I67, I68-9, 1 70, I 7 I, I8 I, 336.

Brampton, 235.

Bread, different kinds of, 54, IO2, 206-7, 230; rye, IOI, I 34, 206; wheaten, a luxury, I01; common, 207 , 240 ; made of turnips, 157 ; price of (see Prices).

Breeding of stock, 37, I46, I67, $215-7$, $256,273$.

Brentford, I 57.

Bridport, 262.

Bright, John, 280.

Buckinghamshire, $78,1_{46}^{6}, 1_{72}, 291$, $306 \mathrm{n}$.

Buckwheat, $33^{2}$.

Budget, labourer's weekly, 206, 208, 356.

Buildings, farm, and repairs, $5 \mathrm{I}, 272$, 279, 282, 299, 302, 307, 310.

Bull, description of a $(1726),{ }^{2} 67$

Burford, riot at, 185 .
Buri, 8, I I.

Bury St. Edmunds, I IO, 147.

Butter, 33, 63 11., 66, I I 4, I 38 , I.40, I6 I, I 74, 205, 206n., 241, 247 (see Prices), $304,305,313,325$; exports of, $326-7$. By-industries of peasant, I I O, 239, 250 , $257,260,269,317$.

\section{C}

Cabbages, I I 2, I 43, I 87, I 91 , I 94, 200, 201,33 I.

Cadaveratores, $\mathbf{I}_{3}$.

Caird, Sir James, 279, 281, 285, 287, 3I0, 3I 4 , 3I 9 .

Cake, 296, 300, 305, 314 .

Calstock, 3I8.

Calves, killing of, forbidden, 86 ; rearing, 125.

Cambridgeshire, 79, I 5 I, I67, 222,262 , $306 \mathrm{n} ., 318$.

Camden, I73, 335 .

Canada, imports from, 323-4.

Canterbury, hops from, I 7 I.

Capital of farmers, $197,203-4$.

Carrington, Lord, 231 .

Carrots, I I 2, I 28, I43, I67, I9 I, I 94, $331,332$.

Carter, wages of, I Io.

Cart-horses, price of, 35 , I I 4 .

Carts, I 53.

Cattle, Chillingham, 336 ; diseases, 85 ; export of, 326, 330; improvement in, $336,337,33^{8}$ (see Cattle, size of); number of, in 1867 and 1878,288 ; in 1907, 333-4; original breed of, $33^{6}$; price of, see Prices; size of, $37,104,146,169,288,336,342$; separation of, for summer pasture, I 24 ; sorts of (I726), I67 (see under Various breeds); about 1800,235 ; in I 839,274 ; in $1892,274,3.36$; time to buy, i 25. (See Bakewell, Collings, Exports, and Imports.)

Cattle plagues, of eighteenth century, I 72, I 85-6, 290; of nineteenth century, 289-9o, 294.

Cauliflowers, I 43 .

Causes of high prices at end of eighteenth century, 240.

Celery, 3 I 8.

Chamberlayne, 259 .

Cheddar cheese, I 73.

Cheese, 33, 63n., 66, I61, I73, I 74, 200, 206 n., $276,305,313,325$. (See Prices, Exports, and Imports.) 
Chelmsford, I IO, I7I, 30\%.

Chemistry, agricultural, 232, 243, 275 .

Cherries, I5, I 29, I30, I31, I36, I43, I 7 I, 329, 332 .

Cheshire, 3, I10, 167, 173, 224, 276, 295, 306.

Chestnuts, 136 .

Cheviots, $344,346$.

Child, Josiah, I17.

Christ Church, Canterbury, 42.

Cider, 37, I 30, I 31, I 35-6, I 49, I 87-9, 207, 269.

Cistercians, good farmers, 29, 327 .

Civil War, checks improvement, II3; family settlements after, I 23 .

Claret made in Oxfordshire, 145.

Clarke, 236.

Close parishes, $158,284$.

Cloth made in England, 69, 70.

Clothes, part of wages, 28, rog; of labourer, 54, 7I, 109, 185, 206-8, 2 II, 3II ; of farmer, I05, 213.

Clover, cost of growing, $19^{3}$; extent of, 331 , 333, 353; introduced, III, 1 I 2 ; spread of, I1 $5,141^{1-2}, 164,166,178$, I79, 19I, 194; seed, price of, 223 ; sown with corn, 166.

Clun Forest sheep, 344, 346.

Clydesdale horse, 335 .

Cobbett, 107, 226, 265, 268.

Cobden, Richard, $279 \mathrm{n}$., 280, $285 \mathrm{n}$.

Coinage, depreciation of, $44,59,89$.

Coke of Holkham, $163,182,224-8$, 275,34 I.

'Coke's Clippings', 227.

Coleseed, I15.

Coliberti, 8.

Collings, the, $146,163,167,233-5,337$.

Combe, 53 .

'Comet,' 234, 235.

Commissions, Royal, on Agriculture, \&c., $260,266,289,294-6,300,303$, $304,305,311+14,316,318,320,329$.

Committees, Parliamentary, 256,258 , 263 n., 266, 267.

Common, John, 303 .

Common fields, $22,26,78$, II 2,113 , I I $8-9$, I 20, I94, 253, 258.

Common land, $3,145,148$; evils of, $148,194,256,257$; improvement of, I66.

Common pasture, see Pasture and Meadows.

Commons, advantages of, 165 ; extent of, in 1795,231 ; rights of, lost, 253 .
Communities and corporations contrasted, 2.

Commutation of labour services for money, 27,45 .

Compensation for improvements, 296, 299-302.

Competition, foreign, 296, 297, 312, $315,319,323-30$.

Consolidation of farms, see Amalgamation.

Contractors for labour, 209.

Co-operation in agriculture, $I$.

Copyholders, 59, 12 I -2.

Corn laws, $63,64,69,70, I_{59}, 160,242$, $248,250,265-6,277-80$.

Cornwall, 136, 186, 295, 309, 318.

Cost of living (1773-1800), $24 \mathrm{I}$.

Cotarii, 8, I I, 25.

Cotswold sheep, 233, 275, 343, 344; wool, famous, 172 .

Cottages, 5 2, I I 7, I 2 I n., I 39, I 58, I 59, 206, 209, 250, 254, 255, 267-8, 285, 297, 304, 3II n., 315-6.

Court Rolls, of Manydown, I3.

Cowper, John, 165.

Cows, decrease in number of, 96 ; increase, 325 ; let out by the year, 34 , 57,65 ; yield of, 33,64 . (See Prices of Cattle.)

Craik improves drill, 202.

Craven, migration from, 44 .

Crimean War, effect of, 277 n., 287 .

Crondall, 28.

Crows' and magpies' nests to be destroyed, 100.

Culley, George, $217,234,337,344$.

Cultivated land, amount of, in 1685 , 120 ; in $186 \%, 288$.

Cultivation, Walter of Henley on, $\mathbf{3 2}^{2}$; of England, in 1688,155 ; the old and new ways of, $177,180,194,200-2$.

Cultivation clauses, $57,178,218,296$, $302,322$.

Cumberland, 238, 295, 309, $311,346$.

Currants, 33 I.

Custom of the country, 299, 300n., 302 (see Tenant right).

Cuxham, manor of, 24.

Cylindrical drain pipes, 272 ,

D

Dairy, the, and dairying, $33,59,168$, 170, I 73, 199-200, 297, 304, 306, 313, 319, 325, 340-I. (See Butter, Cheese, and Milk.) 
Damsons, $15,136$.

Danegeld, 6.

Dartmoor sheep, 344, 346.

Davenant, I I 5, I I 7 , I 20, 260,354 .

Daventry, common fields at, II8.

Davy, Sir H., 232, 276 ; T. T., $34^{2}$.

Dealers, legislation against, $86,93,134$; complaints against, 237 .

Defoe, Daniel, I66, I68, I69, I 7 1, I 74, $220,259$.

Degge, Simon, 122.

Demesne, $7,15,30,45,56,5^{8}, 65,74$, 97,99 .

Denmark, imports from, $241,262,323-$ 4 ; livestock in, 334; wheat crops in, $33^{2} \mathrm{n}$.

Depression, agricultural, $163,183,184$, $223,228,24^{2}, 248,262-70,281,29^{2}$, 293-6, 305-14.

Derby, Lord, estate of, $320 \mathrm{n}$.

Derbyshire, 44, 167, 309, 343 .

Devon cattle, 168, 217, $225,233,274$, 288, 336, 339,340-3. (See Southams.)

Devon sheep, 343,344 .

Devonshire, 37, 73, 107, I 13 $128,13^{2}$, I $36,186,187,244,245,269,272$, $295,306,309,338$.

Devonshiring, I4I.

D'Ewes, Sir S., quoted, II 7 , I 33 .

Dexters, 343.

Dibbling wheat, 135 .

Digging for wheat, I 35 .

Diseases of Animals Act (1890), 290.

Dishley, 2 I4-6.

Distress, law of, 296,301 ; periods of, 42, 68 (see Depression, agricultural), $237,242$.

Divining rod, 232.

Domesday, 5, 14, 16, I 9, 60, 79, 144.

Doncaster, roads near, 221 .

Dorking, manor of, 65 .

Dorset, $3,263,285,291,312,318$; sheep, 344,346 .

Dovecotes, sce Pigeons.

Drainage, I6, 32, I1 3, I2S, I29, I 37 , I $54,163,201,202,213-4,219,230$, $271,273,279,282,288,299,300$, $305,307,310$.

Drills, I I $3, I_{52}^{2}$ I $75-7$, I 80, I $83,200-2$, $226,227,271,274$.

Drinking habits, $207-8,269$.

Drying hops, $15 \mathrm{I}$.

Duchesses, the, 234, $274,338$.

Duckham, Mr., 339 .

Ducks, I 70 (see Poultry).
Dugdale, 77 .

Du-Hamel, 202.

Durham, II 9, 337.

Durham ox, 234, 235 .

Dutch breed of cattle, see Shorthorns.

$\mathrm{E}$

Eakring, common meadows at, 22.

Eardisley, 5 .

East Indies, wool from, 328 .

Eden, account of potatoes, $106,207,238$, 256.

Education Acts, 292, 297.

Egypt, imports from, 323 .

Eighteenth century, general characteristics of, $16_{2}$.

Electricity applied to vegetables, 236 .

Elevator, hay and straw, 304 .

Elkington of Princethorpe, $213-4,230$, 271.

Ellis, Chiltern and Vale Farming, I8o.

Ellman, John, $217,345$.

Enclosers prosecuted in Star Chamber, 120.

Enclosure, 74-82, 85, 92, 96, 97, II9, $173,182,194,228,252-261$; agreement as to, $9^{8}$; acts of, $119,163,196$, 231, 233, 252, 253, 258; amount of, exaggerated, I $2 \mathrm{I}$; different kinds of, 73 I I 9, I65, I96; eighteenth century, $163,165,173,182,183,194,196$, 253; evils of, $194,195,252-3,254-61$, 316 ; expense of, 196,252 ; non-parlinmentary, 165,253 ; a deed of, 75 ; a sign of progress, $76, I_{4}, I_{39}$, I 45-8, 253 ; legislation against, $79,80,120$; checked, 120.

England, appearance of, in fifteenth century, $7^{8}$; in the seventeenth, I 20-I. English invaders, $\mathrm{I}$.

Entails, barred, 122.

Essex, 62, 78, 106, I 28, I 73, 190, 225 , $286,295,306,309,319$.

Estates, great, accumulation of, 123 ; advantages of, 322 ; often a loss, 321 .

Evelyn, John, I $27,149$.

Evesham, Vale of, 318.

Ewes, milking of, 33, 64, 200.

Exhibition, Great, 287,304 .

Exmoor sheep, 344, 346 .

Exporting country, England ceases to be an, 161,163 .

Exports of butter and cheese, 326-7.

Exports of corn, 63n., 64, 70, 159-16I, $183,185,242,267,348-9$; reaches 
its maximum, I86; of livestock, 325-6; of wool, 39, 69, 172, 327.

Extensive cultivation, 2.

Extent of the Manor, 10.

Eyton, Mr., 339.

\section{F}

Faggots, price of, II 4 .

Fairs for hops, I7I ; horses, I05; sheep, I 22 . ; wool, I $72 \mathrm{n}$.

Fallows, atilized, I 12 , I 77, I 81 , $19 \mathrm{I}$, 195 ; in $1877,1907,331$; in 1850,353 .

Families employed on common and on enclosed land, 195.

Farm or feorm, 5 .

Farmer, day's work of, in seventeenth century, 134; discontent of, 127-8, I 84 ; financial position of, IOI, IO3, I $56,162,184$, I $95,204,2$ I 2-3, 243 , $247,257-8,264-5,293,307,308,310$, 320 ; growing more skilful, IOI, I32.

Farmer's Letters, Young's, I92.

Farmhouses, 51, I0I, I I6, II9, 2 I3, 226.

Farming, bad, 273, 28I ; improvement in, $28,111,113,115, I_{32}^{2} 160,162$, I 92, 204,21 I, 22 I, $229,244,265,267$, $271,274,275,281,288$.

Farming calendar, I7, 124.

Farms, in sixteenth and seventeenth centuries, I I6-7; size of (I 768), 202.

Farnham, hops, I 7 I.

Fashion, farming becomes the, I92, 193.

Faltening oxen, $31,5^{\mathrm{S}}, \mathrm{I}_{25}, \mathrm{I}_{36-7}, 166$, 2 I 4, 216,225 n., 235, 288 ; sheep, I I 2 , I66, $225 \mathrm{n}$.; chickens, I70.

'Favourite', 234.

Feeding pigs, I6, I 25.

Fences, legislation as to, 4 .

Fens, the, 78 , I $23,170,318$.

Feversham, fruit growing near, I $28, I_{7}$.

Fifteenth century, character of, 68 .

Figs, 1 5, 93, 136 .

Filberts, 93, 136.

Fitzherbert, 3I, 61, 76, 7\%, 83-5, III, 132,135 .

Fixtures, $30 \mathrm{I}$.

Flanders, cattle, $33^{8}$; clover from, III, 166 ; hops from, 86, I 50; wool exported to, 39, 327; sheep exported to, 326.

Flax, I 7, I05, 135, I 4I, I 5 I-2, I9I, 25 I, $331,33^{2}$.

Fleece, weight of, $37,41,104,200,215$. Fleta, quoted, I 2, I3.
Iiloor, for hop-picking, 91, I 5 I.

Flour, exports and imports of, 348-9.

Fluctuations in price of corn, 35, 66, 89, I $33, I_{42}, I_{57}, 186,22$ I, $223,277$.

Fold soke, 9 .

Folding quality, of sheep, 253.

Food, labourer's, 9, 25, 34, 37, 53, 54,

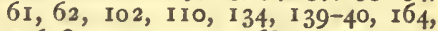
206-8, 2 I I, 240 n., 268, 290-I, 297, 308, 3II ; farmer's, IOI, I 28, 213 , 240 n., $246,308$.

Foot-and-mouth disease, see Cattle Plagues.

Foot-rot, 294.

Foreman, requirements of, 139 .

Forncett, manor of, $25,45,46$.

Fountains Abbey, 81.

Fonr-course rotation, 183 .

Four-field system, 99 .

Fourteenth century, characteristics of, 38.

Fowler, John, 304 .

Fox, the, I $40,244$.

France, exports to, 349 ; imports from, 243,323 ; livestock in, 334 ; small holders of, 202-3; wheat crops in, 332.

Freeholders, see also Yeoman, 119, I 2 I-2.

Freemen, 7 .

Free tenants, 24, 29, 45 .

Free trade, I6r, 277-81, 323; effect of, 281, 284, 288, 293, 296.

French War, great, see Wars.

Fruit, I 5, 93, I 28, I43 ; imports of, 305. Fruit-growing in seventeenth century, $129-131,132, \quad 136$; in eighteenth century, I $17,186-9$; in nineteenth centnry, 319, 329, 330 .

Furlongs, 3, I 8 .

Furnitnre of manor house, 52 ; labourer's home, 52 .

\section{G}

Gafol, 9, Iо.

Galloway cattle, I69, 343 .

Game, damage by, 302 .

Game law, the first, 55 .

Gang system, 292.

Geese, 34, 1 70. (See Poultry.)

Gentry, at the Revolution, I 56 ; estates of, under Walpole, I83 ; status of, 50, 97 ; supplanted, I 22 ; 128 , I $37,140,1_{56}$, 1 84, 21 I, 21 2, 310. (See Landlords and Squire). 
Gerard, I06, III.

'Gerefa, the', 15.

Germany, exports to, 63 ; imports from, $20,66,69,24 \mathrm{I}, 243,262,323-4,328$; livestock in, 334 ; wheat crops in, $332 \mathrm{n}$.

Gilbert, 275 .

Gilbert's Act, 237.

Gilbey, Sir W., 335 .

Glamorganshire, vineyards in, $\mathbf{I} 45$.

Glastonbury Abbey, I3.

Gleaning, 133.

Gloucestershire, 19, 78, 128, 136, 143, I 44, I 73, 207, 295, 344.

Gloves, gifts of, 62 .

Gold premium, 305 .

Googe, Barnaby, I44, I 73 .

Gooseberries, 331 .

Grafting in seventeenth century, 130.

Grain crops, chief source of lord's income, 25.

Grapes, 136, 329 (see Vineyards).

Grass, acreage under, in 1877 and 1907 , $33 \mathrm{I}-2$; in 1850,353 ; arable land laid down to, $56,58,75,79,91,93-4$, II 7-9, 1 20, 196, $219,231,305$; converting, to tillage, 231,263 ; more profitable than arable, I99; seeds, 165, 191, I94, 226-7.

Grass land, price of, see Pasture and meadow, price of; ploughed up, I86, 218,245 .

Grass section of England in 1893, $306 \mathrm{n}$.

Grasshoppers, plague of, 185 .

Graziers, profits of, 184 .

Greycoats of Kent, 259.

Ground Game Act, 303 .

Guano, 232, 276.

Guernsey cattle, 342,343 .

Gun, the, in seventeenth century, 140.

\section{$\mathrm{H}$}

Haggard, Rider, Mr., 314-5.

Hallam, 2 Io.

Hambleton, Sir A. Barker of, I42.

Hamlets, 5 .

Hampshire, 28, 36, 79, I 16, I32, 145, I65 n., 240, 253, 266, 268, 306 n., 309, 314 ; sheep, $275,288,344,345$.

Handborough, 53 .

Harrison, 'Description of England,' $19,28,50,56,86,91,95$, 101, 104, 149.

Harrow, the, and harrowing, I $7,65,84$,
$125,135,141,153-4,166,176,179$, $194,201,203,246$.

Hartlib, Simon, I27, I28, 130, I31, I $32,142-3$.

Harvest, importance of, 9, 108.

Harvest homes, 104, 269.

Harvest work, 25, 62, $125,138,209$.

Hatfield Chase, 78 .

Hawsted, 20, 30, 35, 54, 57, 58, 62, 63,67, I 2, I 5 , I I6, I $78,179,205$, 207.

Hay, II 2 ; price of, see Prices; carrying off, I 78, 219, 302; imports of, 262.

Hay tedder, $30_{4}$.

Haymaking, 4, 44, I $24,125,138,1_{4} 2$.

Headlands, 3 .

'Heaths', Shropshire, 20.

Hedges, I $24,148,1_{50}, 163,178,282$.

Hemp, I00, I05, I35, I 5 I, I I, $250-1$.

Henley, Walter of, I9 n., 31, 36, 83 .

Henry of Huntingdon, 327 .

Hens, number of eggs from, 35 .

Herdwick sheep, 344,346 .

Hereford cattle, $233,235,274,288,33^{6}$, $33^{8-40}, 34^{2}$.

Herefordshire, 5, 40, 128, I30, I32, $136,143,171,186-7,188,240,247$, $249,250,267,291,306,309,316$.

Hertfordshire, $\mathbf{I}_{50}, \mathrm{I}_{74}, \mathbf{I}_{79}, \mathbf{2 2 5}, \mathbf{2 3 8}$, $306 \mathrm{n}$.

Hentzner's description of English farming, 104.

Hide, 16.

Highland, West, cattle, 217,343 .

Hoeing, 153, 166, 188, 201-2, 354; horse, $198,201$.

Holder, the small, 73, 76, I19, 121-2, $164,191,195,202,205,220,253-61$, 268, 308, 310, 311, 316-9; decrease of, causes of, 122, 259 ; new class of, 260.

Holderness cattle, 337 .

Holdings, various sizes of, 334 .

Holland, Shorthorns from, 337 ; live stock in, 334 ; wheat crops in, $332 \mathrm{n}$.

Honey, 10, 144 .

Hops, 28, 86-7, 89-9I, I I I, I25, I 28 , 143, I 49, I 50, I I I, 297-9, 329-30, 331 ; acreage of, in 1729,$171 ; 297-8$, 329 ; average crop, 333 ; duty on, 297-8 ; imports of, 329-30; profit on, 90, I 50, I 7 I, 298-9, 330; substitutes, 298,329 .

Horse fairs, 105.

Horse shoes, 36 . 
Horses, deterioration of, 85,146 ; export of, $325-6$; kinds of, 274,335 ; number of, 333 ; size of, 104, 105, 217 ; tax on, 249 ; working powers of, 3 I , I 53 , 204. (See Prices.)

Houghton, account of potatoes, I06, 127,165 .

Houses, wooden, 5o (see Farmhouses); of the squire and yeoman, Iо3, 2 I2.

Housing cattle and horses, 126.

Howberry, 175-6.

'Hubback', 234.

Hundred Rolls, 28, 76, 327.

Hunting, 140, 210.

Huntingdonshire, 3, 25 n., 72, 120, 123, 222, 306 n., 309 .

Hurdles, 354.

Husbandry, old and new, see Cultivation.

\section{I}

Implenents, cost of, rises, 242 ; in seventeenth century, I $35,152-3,154$; in eighteenth century, $188,194,203$, $229,23^{6}$; in nineteenth century, $27 \mathrm{I}$, $273-5,276,287$ n., 303-4, 316 ; improvement in, 113 ; list of, in eleventh century, $17-52$; prices of, 83,138 .

Importing country, England becomes an, 163 .

Imports cause low prices, 295 .

Imports of clover seed, I66; of corn, 20,63 n., 66, 69, 70, I59-61, 183, $184,223,224,239,240,24 I-4,247$, $248,249,262,266,267,277-80,287$, $293,305,323-4,330,34^{8}-9$; of dairy produce, 325 ; of fruit, 188,329 ; of hops, 150; of linen, 105; of livestock, 161, 280-1, 305, 324-6, 337 ; of meat, $161,305,325,330$; of wool, $39, \mathrm{I} 6 \mathrm{I}, 305,328,354$.

Improvements, amount expended in, 320-1; needed in eighteenth century, $19 \mathrm{I}$; in farming in eighteenth century, 192 (see Agriculture, state of), I93, $2 \mathrm{O}_{4}$ (see Farming).

Inbreeding, Bakewell and, 214; the Collings and, 234-5.

Income and expenditure of landed classes ( I688), I 56 .

Incubators, early, 132.

India, imports from, 324; wool from, 328.

Ine, laws of, as to fencing, 5.

Inherent capabilities of the soil, 301.
Inns, markets for produce, 223.

Inoculation of fruit trees, I3I.

Intensive cultivation, 2.

Irish imports, $161,262,324-5,328$; labourers, 209, 306.

Irrigation, $\mathrm{II}_{3}, \mathrm{I}_{32}, 2 \mathrm{I} 7$.

Isle of Wight, $172 \mathrm{n}$.

Italy, exports to, 349 wool exported to, $39, \mathbf{3 2 7}$.

$\mathrm{J}$

Jamaica, wool from, 328 .

Jersey cattle, 275, 339. (See Alderney.) Jus faldae, 64 .

Justices regulate wages, I07.

$\mathrm{K}$

Kent, 40, I 28, I43-7, I57, I 71, I 73, $186,259,265,283,295,306$ n., 309.

Kentish cattle, 168 ; sheep, 343,344 .

Kerry cattle, 343 .

Kett, rising of, 96 .

Ketton, 233, 235.

Kilns, hop, $15 \mathrm{I}$.

King's, Gregory, statistics, I 20, I 40, I 4 I, I $55,258-9,260,353$.

Kingston, Lord, estate rents of, 116 .

Knights Hospitallers' estates, 40.

\section{L}

Labour, cost of, per acre, 313 ; services, $6,12,25,27,42,45,56,61$.

Labourer, character of, in eighteenth century, 175, 184, $201,204,205$, 2 I0; condition of, at end of eighteenth century, 237-9; condition of, in nineteenth century, $257,266-8,269$, $270,279,283-4,285,290-2,297$, $3^{1} \mathrm{I}-2,3^{1} 3^{-4}, 3^{1} 5,320,355$; decrease of, 305,3 II n., 315 ; life of, in Middle Ages, $53,54,67,71$, 103; made a landless man by enclosure, 196, 257 ; number of (1688), 156 ; savings of, $102-3$, 156 ; sports of, 55 ; the home of the, $5^{2}$, I 58 ; wages of, see Wages.

Lambs, to fall March 25, 126.

Lammas, 4, I1 2, 137 .

Lancashire, 44, 78, 106, I10, 147, 163, $167,207,216,219,282,283,284$, $309,312,316,320,343,346$.

Land, value of, $19,36,40,66,117,133$, $149,183,243,286-7,293,304,310$, $328,34^{8}$.

Landlords, absentee, 184, I9I ; of the fourteenth century, 48 ; new class of, 
$59,75,97,122$; houses of the, I03 (see Cottages) ; improve estates, 132, $162,224,232,255,268,320$; protectionists, 160-I ; ignorant of estate management, $175,193,249,281$; in nineteenth century, $265,28 \mathrm{I}, 304$, $30 \%, 309,320-2$; position, weakened, 399 ; relatiofis of, and tenant, 218 , 226, 282-3, 299, 301, 322 ; suffered most from present depression, 320 ; reserve sporting rights, I I5; take to farming, 182 .

Landlordship, 6.

Lawes, Sir John, 275, 276, 314, 3 I9.

Lawrence, John, I52, 165, 166, 167, I 73,337 .

Laxton, Notts, 22.

Leases, 45, 56, 57, 65, 8 I , 97, I I 3, I I 5-6, I 2 I - 2, I 78, 2 I 8, 2 I 9, 263 n., 272,282 , 283.

Leicester sheep, 21 5-6, 235, 274, 275, 343,344 .

Leicestershire, $8,78,79, \mathrm{I}_{20}, \mathrm{I}_{5} \mathrm{I}, \mathrm{I}_{72}$, I 74, 2 I 4-6, 268, 306 n., 309, 343 .

'Lemmons', 93.

Leominster, manor of, I8; wool, 40, I I, I72 n.

Liberi homines, 7 .

Liebig, $275,276$.

Lime, I I 2, I 41, I 77, I87, I97.

Limestone sheep, $344,346$.

Liming the land, 77, I $_{3} 3,2$ I $8,219,246$, 300 .

Lincoln red cattle, 343 ; sheep, 2 I 5, 23.5 , $275,288,343,344,346$.

Lincolnshire, 3,8,40,99, 100, 103, I $23, I_{5}$ I, I 68, I $72,250,252,255,283$, 306 n., 307,3 I 8, 32 I.

Liquorice, 143, 19r.

Liverpool, apples at, 188 ; wheat at, 185 .

Liverpool, Lord, 232, 264.

Live stock, depreciation of, 306,330 ; exports of, $325-6,330$; number of ( 1877 and 1907$), 333-4$; in England (1688), I 55,164 ; duty on, repealed, 280.

Locusts in England, 185 .

London, affects wages, 205 ; attracts country folk, 209, 210 ; potato grown near, 106 ; carrots grown near, 167 , I68; roads near, 222 ; sheep and cattle driven to, $22 \mathrm{I}$.

Longhorn cattle, 167, 216-7, 233, 234, $274,275 \mathrm{n} ., 336,343$.

Longmynd, 345 .

Lonk sheep, $344,346$.
Lord of the manor, 6, I4, 19, 25, 42, I 2I, I 27, 255; small holder suffers at his hand, I2I.

'Lord Wilton', 340.

Lucerne, I43, I67n., I9I, 201.

Luffenham, South, 22 ; North, 103.

Luxury, spread of, 2 I I, 243, 264.

Lyttelton, Sir H., I 45 ; Lord, I83.

\section{M}

Macadam, 220, 223, 230.

Machinery, use of, $27 \mathrm{I}$.

Madder, I7, I 43, I9 I, I94.

Maidstone hops, I 7 I.

Maize, imports of, $262,296,313$.

Mangolds, 237, 33I-2, 333, 353 .

Manor, regulations of the, I3, 99 .

Manor, the typical, I4.

Manorial balance sheets, 26,65 .

Manorial system, 6, $7,18,24,45,76$, 97.

Manors, 6, 7, I4, I8, $25,42,45,65,97$, 99, I 18.

Mansion house, I4, 50 .

Manufactures, influence of, on wages, $284,297,3$ I 5.

Manures, I I 3 , I I 9, I 36 , I 44, I 50-4, I 77 , г 78, 179, 187, 19г, 197, 201, 219,221 , $254,275-6,296,299,300,304,305$, 3I 4 .

Manydown, Hants, I3.

Market gardening, 306, 308, 319 .

Markham, Gervase, I 27, I 34-7, I46, I 5 I, I 1 .

Marling, 77, I13, I83, I91, 197, 202, $219,300$.

Marshall, William, r88, 204, 207, 2 I3, $222,298,314,336,338,340$.

Maryland, wool from, 328 .

Mattocks for breaking clods, 129.

$\mathrm{M}^{\circ}$ Cormick, 303 .

$M^{c}$ Culloch, 28I, $324,349$.

Meadowland, 2, 19, 22, 40, 58, I 55 .

Meadows, I6, 30, 73, 99, 100, I I 8, I 24 , $I_{4} 8,253,258$; value of, 40,58 , I $15-6$, I 39, 23 I .

Meat, imports of, $161,305,325$.

Medlars, 136.

Meikle, 230, 236.

Menzies, 236.

Merino sheep, 233, $328 \mathrm{n}$.

Messor, the, $\mathrm{I}_{3}$.

Middlesex, 4I, 145, 306n.

Midland counties, enclosure in, 120 ; sheep in, 2 I6, 2 I 8. 
Migration of labourers, $44, \mathbf{I}^{8 \mathrm{n}}$., 209, 238.

Milk, 63n., I68 (see Dairy), I 70, 205, $275,297,330$.

Mill, suit of, 9 .

Mills, excessive number of, I I4.

Minimum wage proposed, $24 \mathrm{I}$.

Minister of Agricalture, 305.

Mixtil, or mastlin, or mesling, 9, I02, I 25, $138,207 \mathrm{n}$.

Moles, I I $4,124$.

Molton Market, $34 \mathrm{I}$.

Monasteries, 68, 8r.

Money payments, 24, 27, 45, 56 .

Mortimer abuses the law, 74 .

Moryson, 102, 105, 122.

Mountain sheep, $344,346$.

Mowing corn, Fitzherbert's advice, 84, I 2 5, I 35, I 38, I 99, 354; machines for, $303-4$.

Mowing grass, cost of, $34,44,65,71$, I09, I 38 , I 42, 348, 354 ; Fitzherbert's advice, 84 .

Mulberries, I $5,1_{46}$.

Murrain, I3, 42 n., 68.

Mutton, price of, see Prices.

\section{$\mathrm{N}$}

New world, influx of precious metals from, 89 , I I I.

New Zealand, wool from, 328.

Newark, I57:

Nitrate of soda, 276.

Non-intercourse Act of United States, 242.

Norden, Sir John, I 27-8, 220.

Norfolk, 8, 40, 45, 63 n., 94, 96, 97, I 67 n., I69, I 70, I82, $217,224-8$, $306 \mathrm{n} ., 308,340$.

Norfolk, or four-course rotation, 183 .

Normandy, $33^{8}$.

North, difference of wages between, and South, 283-5; superior thrift in, 207-8.

Northamptonshire, $8,78,79$, I 20, I5 I, I57, I7 2, 222, 306n.

Northleach, rates at, 295.

Northumberland, 193n., 236, 295, 303, $309,346$.

Norwich, I69, I82.

Nottinghamshire, $8,22,78$, I16, I44, I 72, 237, 276, 283, 306n., 308, 309.

Nowton, Suffolk, 57 .

Nucleated villages, 5 .

Nuts, 136.
Oak timber, value of, I37; Coke's, $225-6$.

Oakham, I Io.

Oats, 20, 33, 65, 9I, I 24, I35-8, I42, I $55,227,305,33 \mathrm{I}-2,353$; cost of growing, in 1770,199 ; produce, per acre, in $1712,165 \mathrm{n}$.; in $1770,197-9$; profit on, I80. (See Prices.)

Occupiers of land, 355 .

' Old Comely', 216.

Olives, 93, 136 .

Onions, 143, 332.

Open parishes, I 58, 284.

Oranges, 93.

Orchards, I7, I28, I 31 , I43, I86, I88, 255,332 ; seventeenth century, $135-6$.

Owners and occupiers, percentage of, 334 .

Owners of Land, return, 260-I.

Owners, small, see Holders, small.

Ox teains, I6, 31, 64, 84, I43, I47, I 53, I9 I, 204, 340.

Oxen, description of, in $159^{2}, 104$; value of, I 9, 20, 35, 57, 66, I I4. (See Cattle, price of.)

Oxford, $63,273,338$.

Oxford Down sheep, 275, 288, 344, 345 . Oxfordshire, 24, 40, 78, 99, I 45, I5 I, I 75, 273-4, 306 n., 309.

\section{$\mathrm{P}$}

Pack-horses, use of, $\mathbf{I}_{3} 8$.

Packing fruit in seventeenth century, I 29, I 30.

Paring and burning, I4I, I53.

Parsnips, I 43.

Pasture, breaking up, 2 I8.

Pasture, common, 2, 4, I6, I9, 73, 99, I I3, I95; often worth little, 256 ; permanent, in Holdings Act, 299; extent of, in 1688,155 ; in 1770,196 ; ploughed up during French War, 243; sparing, I 24 .

Pasture land, price of, 4I, 59, II 5-7, 139.

Patents, I I $3,236$.

Peaches, I5, 93, I36.

Pears, I5, 93, I 30, I 31 , I36, I43, 329, $33^{2}$.

Peas, 33, 69, 124, I55, 200, 22 7, $331-2$ 353.

Peasants' revolt, 60.

Peel's drainage loans, 272. 
Penalty for breaking up pasture, 178 .

Perry, 130.

Pestilences, $38,42,68,79$.

Piecework, 28, 163, 206.

Pigeons, number of, 49, 96, 105, 143, 244, 274, 275.

Pigs, export of, 330 ; feeding, 16,125 ; foot-and-mouth disease attacks, 290 ; import of, 326 ; number of, 333-4; profit on, in $176_{3}, 200$; size of, in I592, I04; value of, 20,35 n., 96 , $200-3$; varieties of, I 70,346 . (See Prices.)

Pinchbeck, 103.

Pitt, William, 238, 239.

Plat, Sir Hugh, I $27,152$.

Plattes, Gabriel, 76, I 27.

Pleuro-pneumonia, see Cattle plagues.

Plot, I 45 .

Plough, eleventh- and twelfth-century, I7.

Ploughing, cost of, $33,65,135,141$, I 77, 179, 246; months for, I7, I 24 .

Ploughland, the, I6, I 8.

Ploughs and ploughing, $65,83, I_{3}$, I 25, I 29, I $35,143,147,150,153$, $177,191,203,217,218,225,273$, 342,354 .

Plums, I5, 93, I30, I31, I 36, 329, 332. Poaching, $4^{8}$; by labourers, 55,210 , 248, 282, 291.

Population of England, 79, 89, III, I $20,140,156,160,163,211$, $240,287$.

Pork, price of, see Prices.

Porter, 'Progress of Nation,' 276, 279, 286, 287.

Portugal, exports to, 349 .

Potatoes, 106, 107, I I2, 187, I9I, I 94, $227,318,331-3,353$; disease, 277 .

Poultry, 4I n., 66, So, I32, I69, I 70 (sec Prices); carrying, to London, I 7 I.

Praepositus, I 2.

Precarii, or boon days, 9 .

Precious metals, influx of, 89 , III ; scarcity of, $66 \mathrm{n}$.

\section{Prices:}

Apples, I 5, 65, 188, I89.

Bacon and pork, 96, 102, 238, 239, $263,313,334$.

Barley, 20, 35, 69, I I4 , I 33, I38, 142, ${ }_{55}, 179,223,247,3^{12}, 347,35^{0-3}$.

Beans, $35,155,180,347$.

Beef, 96, I02, I I 4 , I64, 206 n., 239, $240,241,242,247,262,263,265$, 285,3 I $3,334,356$.

\section{Prices :}

Bread, 206n., 207n., 223, 230, 242 n., $280,285,286,291$.

Butter, 33, 66, II 4, 206 n., 24I, 247 , $285-6,3$ I 2, 334, 347.

Carts, 203.

Cattle, I9, 20, 35, 4I, 65, 89, I05, II 4, I $19,133,146,163,165 n_{0}, 167,169$, $203,235,263,307,312,347$.

Cheese, I73-4, 206 n., 241, 242, 312, 334,347 .

Clover, 166.

Eighteenth century, $145,160,163$, 164,165 n., 166, 167, 169, 170, 172, I 73-4, I79, 180, I 86, 188, 189, 200, 203, 206n., 222, 223, 227, 229,230 , $231,237,238,239,240,285,341,355$.

Fifteenth century, 40, 66, 69, 355.

Fourteenth century, 39, 40, 41, 59, 65 , 327,355 .

Flax, I 52 .

Grapes, 144 .

Harness, 203.

Hay, I 57, I65n., I66, 24I-2, 262, 347 .

Hops, $87,89,150,247,298,330,347$.

Horses, I 9, 20, 35, 36, I I 4 , I 42 , I 65 n., $203,347,355$.

Horse-shoes, 96.

Implements, 83 , I 38 .

Malt, 89, 240, 24I.

Milk, I68, I 70, 312.

Mutton, 96, 102, $206 \mathrm{n} ., 239,240$, $24 \mathrm{I}, 247,262,263,265,313,334$.

Nineteenth century, $227,235,240$, $242-4,245,247-8,262,263,264-6$, $267,277-81,285,287,293,295,296$, $305,306,307,312,324,329,330,334$.

Oats, $20,35,69$, I I $4, I_{3} 8, I_{55}, 180$, 223, 24I, 3I 2, 347, 350-3.

Peas, 69, I 55, 200, 247 .

Pedigree cattle, 234, 235 .

Pigs, 20, 4I, 96, 200, 203, 347 .

Potatoes, I06.

Poultry and"eggs, 4I, 96, I I 4, 133, 170, 247, 347.

Rabbits, I74.

Rams, 202, 215, 235 .

Rollers, 203.

Rye, 4, I6, 9 I, I 25, I 33, I38, I 55, 347. Saffron, ro6.

Seventeenth century, 89, I IO, I 11 I II 4, I 8,1 I 9, I $27,133-4$, I $38,142,144$, $I_{46}, I_{50}, I_{52}, I_{57}, I_{59}, I_{60}, 328,355$. Sheep, 20, 35 n., 36, 4I, 80, II 4,138 , $16_{5}$ n., 203,206 n., $26_{3}, 312,347$. 
Prices :

Sixteenth century, $80,87,89,95,96$, 102-6, 109, 355 .

Straw, I79, I80.

Tenth century, I9.

Thirteenth century, 33, 35, 39, 355 .

Twelfth century, 20.

Vetches, I55.

Waggons, 203-4.

Wheat, 20, 35, 66, 69, 89, I Io, I I 4, $1_{33}, I_{34}, I_{3} 8, I_{42}, I_{55}, I_{57}, 1_{60}, 1_{3}$, I 64, I 79, I 86, 22 3, 23 I, 237, 238, 239,

$240,24 \mathrm{I}, 242-4,247-8,262,265$, $277-8,28$ r , 293, 306, 31 2, 334, 347, $350-3,355$.

Wine, $r 45$.

Wool, 39, 40, 80, 89, 96, II 4, I I 8, I I 9, $142,163,172,173,223,239,242$, $28_{5}-6,306,312,327,328,329,347$.

Prickly comfrey, 237.

Proclamation as to wages and prices, 42 . Production, increased cost of, $295,3^{\mathrm{I}} 3$. Prosperity, agricultural, 28, IoI, I I4, I63, I83, 2 IO-I, 229, 243-4, 246, 264,287 ; during French War, 243-6, 247,264 .

Protecting fruit from blight, \&c., I87.

Protection, effect of, $250,278-9,281$; highest limit of, $248 ; 265,266,277-9$.

Provender rents, 6.

Pruning fruit trees, $131,136$.

Pulverization of soil, 175 .

Quarter Sessions, assessment of wages by, 108.

Quartly, Francis, 34I.

Quia Empiores, statute of, 29.

Quinces, I5, I 36 .

Quit, notice to, 300, 301, 302 .

$\mathrm{R}$

Rabbits, rearing, 174 ; reserved to landlord, I 5 .

Railway rates, 295-6.

Rake, horse, 304.

Raleigh introduces potatoes, 106.

Rams, ewes to, 126 , $13^{8}$; price of, 202, 2 I $5,235$.

Ramsey, 72.

Raspberries, $33 \mathbf{I}$.

Rates, 229, $238,241,245,247,248$, 249, 255, 269, 284, 295, 296, 307, 3I 4 .

Rathgib, Jacob, ro4.
Reaping, cost of, 34, 44, 65, 7 I, I09, I I 0 I 38 , I 77, I 79, I 80, 246, 348, 354 ; machines, 303-4; time for, 124 ; versus mowing corn, I35.

Red Polled cattle, 343 .

Reeve, I 2 ; duties of $\mathrm{a}, \mathrm{I}_{7}$.

Reigate, Flaunchford near, 64 .

Rents:

Twelfth century, 27 .

Thirteenth century, $36,57,75,348$.

Fourteenth century, 40, 41, 46, 65, 75, 348 .

Fifteenth century, 57, 58, 66, $34^{8}$.

Sixteenth century, 66, 76, 95, I I 5,116 , 348.

Seventeenth century, I I5, I I6, I I7,

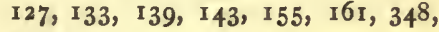
354 .

Eighteenth century, I I 6, I 77, I79, I83, I 89, I 93 n., 224, $227,328,348$.

Nineteenth century, $243,246,248,264$, $266,278,285-6,287,297,304,306-9$, 310, 3 I9n., 32 I-2.

Repairs, see Buildings, farm.

Restrictive covenants, see Cultivation clauses.

Revival, recent, in agriculture, 320 .

Revolt, Peasants', 6o.

Revolution, agricultural and industrial, I62.

Ridges, high, I 29, 175.

Rinderpest, see Cattle plagues.

Riots, $185,223,262,266$.

Ripon, I47.

Roads, 2 I, 68, I05, I 38 , I7 I, I75, I82, $204,210,219,220-3,269,274,295$.

Rock and Far Forest district, 318.

Rogers, Thorold, I07, 229.

Roller, farm, in seventeenth century, I35.

Rolling, I66, I94.

Romney Marsh sheep, 344 .

Romsey Abbey, I $5 \mathrm{n}$.

Roots, few, used for cows, 200 (see Turnips).

Roscommon sheep, 343 .

Roses, I43.

Ross, John, of Warwick, 76.

Rot, see Sheep rot.

Rotation of crops (see Four-course and Three-field system) 225,275 .

Rothamsted, 275.

Roundsman system, 239.

Royal Agricultural Society, 273-4, 281, 308.

Royal Society, helps agriculture, II4. 
Russia, imports rom, $323-4$; wool from, 328 .

Rutland, 22, 102, I09, I10, 1 20, 134, I 42, I I I, 255, 268, $306 \mathrm{n}$.; Dukes of, I I $5,286$.

Rye, 4, I6, 9I, I 25 , I33, I38, I 55 ; in Norfolk, 182,276 ; produce, per acre, in 1770 , 197.

Rye-grass, $178-9,218,276$.

Ryeland sheep, $344,345,346$.

\section{$\mathrm{S}$}

Saffron, 62, 106, 143, 167; Walden, 106, 167.

Sainfoin, II 2, I15, I43, I9I, I94, 225 , 331.

Saint Paul's, manors of, 16, 29, 50, 57, 58.

Sales, famous, 234 n., $235,338,339$.

Salt, value of, 26 .

Samford Hall, 190.

Scotland, cattle of, 336,343 ; wheat crop in, $332 \mathrm{n}$.

Scott, Reynold, 89, I 5 I.

Scottish cattle, I68-9.

Scudamore, Lord, I 32, 338.

Seasons, bad, 20,42 n., 66, 69, 89, II5, 157, I79, I84, I85, I86, 210,223 , $224,237,239,242,243,247,262$, $265,277,29^{2}, 293,294,295,297$, 305 ; good, 239, 244, 262, 266, 287 .

Seed, amount of, for wheat, $33,67 \mathrm{n}$., 84 , I 77, I 79, I 80, 227,246 ; for clover, I 1 $2,166,176,218$; clover, price of, 166.

Sefton, Lord, estate of, $320 \mathrm{n}$.

Selions, 318.

Self-binding reaper, 304 .

Seneschal, I 2.

Settled Land Acts, 305.

Settlement, law of parochial, I $57-8$, $209,238,269$ n., 284 .

Settlements, family, I $23,259-60$.

Seventeenth century, characteristics of, III.

Sheaf-binding apparatus, 237.

Shearing sheep, 125.

Sheep, 94, 104, 126, э37, 146, 161, $200,225,233,236,263,274,275$, 288,290 ; diseases of, 84 ; export of, 326,330 (see Live stock); improvement of, 37, 164, 202 ; number of, in 1867,288 ; in 1877 and $190 \%, 333^{-4}$; price of, see Prices; varieties of, I I I, I 72, 2 I 5-7, 233, 235, 275, 288,
$343-6$; washing, cost of, 65 , I 25 , 354 .

Sheep-rot, 184, 242, 265 n., 294.

Shepherd, wages of, 6I, 7I, 87, Iog.

Shire horse, 35,335 ; Society, 335 .

Shoeing, $36,65,84,203$.

Shorthorn cattle, $167,225,233-5,274$, $288,336-8,339,342$.

Shows, Agricultural, $233,273-5,34 \mathrm{I}$.

Shropshire, I I n., I6n., I 59, I 73,219 , $220,225,250,339$; sheep, 275,288 , $344,345,346$.

Siberian Railway, 324 .

Sicks, uncultivated patches, $99 \mathrm{n}$.

Sinclair, Sir J., $229,230,232$.

Sittingbourne, 128,143 .

Sixteenth century, character of, 89 .

Slaves, 8, I I, 20.

Smith, Adam, I34, 2 Io.

Smith of Deanston, 214,27 I-2.

Smithfield, I68, I69; cattle show, 2 I8, 273, 339; prices at, 239, 240, 24I, $247,265$.

Smyth, John, III.

Society, Royal Agricultural, I 93.

Society for Encouragement of Arts, \&c., I $94,227,303$.

Socmen, 7 .

Somerset, I9, 58, 107, 168, 250, 309, 340 ; sheep, 344.

Somerville, Lord, 23 I.

Southams cattle, 342 .

Southdown sheep, $217,225,233,236$, $263,274,275,344,345$.

Spade, prejudice against, II $2, I_{43}$; for hops, I 50.

Spain, exports to, 349 ; imports from, 323.

Spanish wool, 38-9, 328 .

Speculation, in land, 243 ; in produce, 305.

Speenhamland Act, 237-8.

Spencer, Earl, 273.

Sporting rights reserved, I I 5 .

Spraying fruit, 136 .

Squatters, $220,256$.

Squire, the, I03, I $28,137, I_{40}, 1_{93}$ 2 I I 2 .

Stafford, Marquis of, 219.

Staffordshire, 3, 44, 78, I 22,2 I 9, 286, 295, 309.

Statesmen, 3 I I.

Statistics, agricultural, 230, 23I, 232, 277,288 (see King, Gregory), 33I-2, 3.53 . 
Statute of labourers, 43.

Statutes quoted:

20 Hen. III. c. 4, 73.

25 Edw. III. 2. c. I, 43 .

$34 \mathrm{Edw}$. III. c. 20,63 .

I 2 Ric. II. c. 4, 6I.

I 2 Ric. II. c. 5,64 .

I 2 Ric. II. c. 6,55 .

I 3 Ric. II. c. 13,55 .

I5 Ric. II. c. 5,7 I.

I7 Ric. II. c. 7, 63.

4 Hen. IV. c. I4, 67 n.

7 Hen. IV. c. I $7,70$.

9 Hen. V. c. $5,68 \mathrm{n}$.

3 Hen. VI. c. $2,326$.

3 Hen. VI. c. 4,327 .

4 Hen. VI. c. 5,64 .

I 5 Hen. VI. c. $2,69$.

23 Hen. VI. c. 12, 7 I, 87.

3 Edw. IV. c. 2, 70.

3 Edw. IV. c. 5, 7 In.

$22 \mathrm{Edw}$. IV. c. I, 7 I n.

4 Hen. VII. c. I9, 79, 94, II 7 .

I I Hen. VII. c. I3, 325 .

I I Hen. VII. c. 22,87 .

6 Hen. VIII. c. 3,87 .

6 Hen. VIII. c. 5,79 .

2 I Hen. VIII. c. $8,86$.

22 Hen. VIII. c. $7,326$.

24 Hen. VIII. c. 3, IO2.

24 Hen. VIII. c. 4, I05.

24 Hen. VIII. c. Io, 82 n.

25 Hen. VIII. c. I, 86.

25 Hen. VIII. c. 13,80 .

27 Hen. VIII. c. 6,85 .

27 Hen. VIII. c. 22, 94 .

$3^{2}$ Hen. VIII. c. 13,85 .

I Edw. VI. c. 5, 326.

3 and 4 Edw. VI. c. I9, 86.

5 Edw. VI. c. I4, 86.

2 and 3 Phil. and Mary, c. 3, 96.

5 Eliz. c. 4, I07.

5 Eliz. c. $5,105$.

8 Eliz. c. 3, 326.

8 Eliz. c. $15,82 \mathrm{n}$.

I3 Eliz. c. 25,96 .

I4 Eliz. c. I I, 82 n.

31 Eliz. c. 7, 12 I n., I59.

39 Eliz. c. I, II .

39 Eliz. c. 2, I I8.

39 Eliz. c. $18,82 \mathrm{n}$.

43 Eliz. c. $2,296$.

I Jac. I. c. I8, I50.

2 I Jac. I. c. 28, II $8 \mathrm{n}$.

I 2 Car. II. c. 4, I6I.

CURTLER
Statutes quoted:

I 3 and I4 Car. II. c. I8, 326, 327 .

I4 Car. II. c. I 2, 157.

I5 Car. II. c. 7, $134,326$.

I8 Car. II. c. $2,161,326$.

22 Car. II. c. I3, 326.

32 Car. II. c. 2, I6I, 326.

$3 \mathrm{~W}$. and M. c. $2, \mathrm{I}_{5} 8$.

8 and $g$ W. and M. c. $30, I_{5} 8$.

7 and 8 Wm. III. c. 28,327 .

36 Geo. III. c. 23,238 .

$4 I$ Geo. III. c. IO9, $231-2$.

9 Geo. IV. c. $60,278$.

4 and 5 Wm. IV. c. $76,269$.

6 and 7 Wm. IV. c. 71, 270.

5 Vict. c. I4, 278.

9 and 1o Vict. c. $22,280$.

9 and Io Vict. c. 23,280 .

$I_{4}$ and I5 Vict. c. $25,301$.

30 and 3 I Vict. c. I $30,292$.

$3^{8}$ and 39 Vict. c. 92, 299.

43 and 44 Vict. c. 47,303 .

46 and 47 Vict. c. $61,300$.

59 and 60 Vict. c. I6, 3 $14 \mathrm{n}$.

$6_{3}$ and 64 Vict. c. 50, 30I.

I Edw. VII. c. I3, 3I4 n.

6 Edw. VII. c. 56, 30I.

7 Edw. VII. c. $54,316$.

Steam, applied to threshing, 237 ; cultivator, 304 .

Stilton cheese, I 73-4.

Stinting the common pasture, 4 .

Stock and land leases, 57 .

Stocking a farm, I $70,203$.

Stores, public grain, 133, 264.

Stott, the, or affer, $35,57,65$.

Stonrbridge Fair, I 7 I, I $72 \mathrm{n}$.

Stratfieldsaye, 272 .

Straw, as winter food for cattle, 126 , 217 ; carrying off, $178,219,302$; price of, I 79, I80, 330 .

Strawberries, I5, 329, 331 .

Stubble, grazing of, 4,125 .

Suffolk, 8, 30, 40, 57,63 n., 78, I 12, 128, 147, 166, 168, I70, I 73, I 74, I 88, $207,225,238,284,306$ n., 309 , 31 3; Punch, 335; sheep, 275, 344, 345.

Supplies of corn per head, $33^{\circ}$ (see Wheat, home supplies).

Surrey, 64, 128, I43, 144, 168, 180, 283 , $306 \mathrm{n}$.

Surveyor, the seventeenth-century, 127 .

Sussex, 54, 78, 259, 263, 283, 306 n.; cattle, $274,288,336,340,343$.

Swanage, 262. 
Swedes, 227, 237, 276, 288, 331-2, 333 .

'Swing' riots, 266.

$\mathrm{T}$

Taltarnm's case, effect of, I22.

Tamworth pigs, 346 .

Taunton, manor of, 18 ; good farming near, 128.

Taxes, 247, 263-4, 307, 310; weight of, $183,191,229,245,246,249,250$, $263,320,321$.

Tea, drinking, $205,207,2 \mathrm{I} 3,29 \mathrm{I}$; price of, 205 .

Teams, composition of, 16 .

Telford, 220, 222.

Tenant farmers, assist in agricultural progress, 162 ; number of, $141, I_{5} 6$; origin of, 46, I 19 .

Tenant-right, 283 .

Teeswater cattle, 337 .

Tewkesbury, 255.

Thatchers, I 39,354 .

Thomson of Banchory, 276 .

Thorney and Woburn estates, 321.

Three-field system, 4, 99 .

Threshing, cost of, $34,44,65,163$, I 79, I 80 , I 98-9, 246; machine, 230, $236-$ 7,282 ; time for, $17,126$.

Tillage, decrease of, $79,80,94$; encouragement of, 79, ro8, II7-8; reaction against, II8. (See Arable, and Grass.)

Timber (see Oak timber), 227 ; spolls crops, 282.

Tiptree, 319.

Tithe, dispute, IO2; on turnips, I66; rent charge, 270.

Tithes, II6, I44, I 5 I, I 89, I95, 230, $232,247,248,249,250,270,305$, $30 \%$.

Tooke, I79, 266.

Tours, Young's, I90, I92.

Towns, movement of rural population towards, $64,70,108,185,192,195$, 209, 3I5, 316-7.

Townshend, Lord, I 63, I82-3, I92, I93.

Treatise on Husbandry, 33, 54 .

Tull, Jethro, I52, I63, I $74-7$, I $_{78}, 180$, $183,193,200-1,204$.

Turkeys, I 70.

Turkish dominions, imports from, 323 .

Turnip catters, 276.

Turnip fly, remedies for, 166 .

Turnips, 93, II I, II 2, I I 5, I4I, I43, I 57, I 64, I 66, I 68, I 78, I 83,25 I,
$33^{1-2}, 333$; cost of growing, in 1770 , 198 ; injure wool, 329 ; sheep first fattened on, I I 2 ; spread of, in eighteenth century, I65, I 66, I 79, I 9 I, I 94, 200, 201,225 ; varieties of, in I $726,165$. Tusser, $63,90,91,92$, I I I, I02, 105, I $11,124,126$.

Two-field system, 3 .

'Twopenny', 2 I 6.

U

Underwood, value of, in seventeenth century, I37.

Unions, Agricultural Labourers', 291-2. United States, see America.

Unreasonable distr:rbance, 302 .

Upwey, 3 I8.

\section{V}

Vaughan, Rowland, I 32-3.

Vegetables, I 5, 93, I 06, I I 2 n., I 43, $236 \mathrm{n}$.

Ventnor, vineyard at, 145 .

Vermin, destruction of, 82, I00, 244.

Vermuyden, Cornelius, I 23 .

Vetches, 125, I 55,33 I.

Village, the, of the eighteenth century, I64.

Village smith, the, 35 .

Villeins, $6,7,8,18,24,29,42,45$; disappearance of, $46,59,60$, 105 .

Vills or villages, $2,5,7, I_{5}, 98$, I I9.

Vineyards, 15, I6, I I I, I 44-5.

Virgate, 8.

Virginia, potatoes from, I06; wool from, 328 .

\section{W}

\section{Wages :}

Twelfth century, 27 .

Thirteenth century, 27, 28, 34, 348, 355.

Fourteenth century, 27, 28, 41, 43, 59, $61,62,348,355$.

Fifteenth century, 67, 71, 348, 355 .

Sixteenth century, $67,87,348,355$.

Seventeenth century, I I 9, I $38, I_{39} 348$, 355.

Eighteenth century, I63, I64, I84, 203, $205-6,210,237,238,240,285,348$, $354-5$.

Nineteenth century, 24I, 242, 249, 267 , $268,283-4,285,290-2,297,309,3$ I I, 312,3 I $3,315,355,356$.

Wages, on a farm in 1805,247 ; regu- 
lated by statute, $43,61,71,87$; by Justices, 10\%, I09, I 10.

Waggons, 153,204 .

Wainage, 8.

Wales, cattle of, $167,336,33^{8}, 343$.

Wallachia and Moldavia, imports from, 323.

Walsingham states demands of villeins, 60.

Wars, effect of, 38, 68, 7I, 193, 205, $212,229,237,260,286,287,341$.

Warwickshire, 40, 77, 78, 94, 1 I0, 172 , I 73, 2I 3, 2I 5, 216, 272, 282, 290, 306 n., 309, 343.

Waste land, 231 ; committee on, 255 n., 256 ; good crops from the, II9; Young and, I9r.

Water carriage, cheapness of, 2 I, I 73.

Weaning lambs, time for, 125.

Weaving, 70, 76, $110,257$.

Webster of Canley, 2 I6.

Weeding hook and tongs, 84, I 52 .

Weeds, 125, 180, 20 r.

Week work, 8.

Welsh mountain sheep, 344,346 .

Wensleydale sheep, 343,345 .

Westcar of Creslow, 339.

Westcote, I 28.

Westmoreland, 2 I 6, 295, 346.

Weston, Sir R., introduces clover, I I I, I 27, I4I.

IVeyhill Fair, I72.

Wheat, acreage under, in 1907, 33 I-2 ; consumption of, per head, 279 ; cost of growing, I77, 180, 198, 199, 246, 307 ; crops, 33, 67, 77, 91, I 29, 142, I 55, I65, I 79, I 80, I $97-9,227,246$, $282,285,286,332$; cultivation of, 4 , $16,32,3^{6}, I_{1} 3, I_{2} 5$, I 35 , I $77-9$, I 80 , 184,353 ; different kinds of, 146,167 ; home supplies of, 277, 279, 313, 330 ; price of, see Prices.

White, Gilbert, 223.

Wilton, hops near, I 7 I.
Wiltshire, $143,174,253,268,283$, 286, 309, 31 2, 313 ; sheep, 345.

Winchelsea, Lord, $255,257,268$.

Winchester, $1_{47}, 1_{50}$.

Wine, 144-5.

IVire binder, 304 .

Wirral, 66.

Wisbech, 3 I8.

Woad, I7, I52.

Women, work of, on the farm, 62, 85, 206, 316.

Wood, W. A., 304.

Woods, 2, 16, 59, 74, 78, I 1 5, I 25, 136, I 55 .

Woodstock, 53 .

Wool, 37, 38-41, 69, 75, 80, 94, 104, I $14,118,119,142,161,163,171-3$, $184,223,285,329,354,355$; export of, see Exports; import of, see Imports; price of, see Prices.

Wool, custom of picking refuse, 100 ; storing, 125.

Worcestershire, 74, I $28,1_{36}, 1_{43}, I_{7}$ I, 306.

Work, hours of, 87, 147, 291 .

Worlidge, John, I 27, I 31, I 32, I 42-8, $150-4,165$.

Worsley, Sir R., I 45.

\section{Y}

Yeoman, the, 50, 7 I , I 23, I 28, I40, I 56, 207, 258-61, 310, 320; house of, 103 .

Yeomen purchase lands of gentry, I 22.

Yorkshire, I 5, 78, I 10, 138-9, I 67, I 68, $207,225,253,283,295$, 3०6 n., 309, $337,343,346$.

Young, Arthur, $160,162,16_{3}, 172,180$, I 82, I 88, 190-3, I94, 197, 200-6, 2 10, 2 I I, 2 2 2, 224, 230, $232,236,240,253$, $255,257,260,284,285,288$ n., 298, $314,317,335,336,337,343,353,355$; opposed to drilling, 178 ; pet aversions of, I9I ; statements of, as to growth of clover, II 2. 
OXFORD

PRINTED AT THE CLARENDON PRESS

BY HORACE HART, M.A. PRINTER TO THE UNIVERSITY 


\section{CLARENDON PRESS BOOKS HISTORY}

\section{Greece, Italy, Egypt, etc}

Clinton's Fasti Hellenici, from the LVIth to the CXXIIIrd Olympiad. Third edition. 4to. £1 14s. 6d.net. From the CXXIVth Olympiad to the Death of Augustus. Second edition. 4to. $£ 1$ 12s. net. Epitome. 8vo. 6s.6d. net. Clinton's Fasti Romani, from the death of Augustus to the death of Heraclius. Two volumes. 4to. $£ 22$ s. net. Epitome. 8vo. 7s. net.

Greswell's Fasti Temporis Catholici. 4 vols. 8vo. £2 10s. net. Tables and Introduction to Tables. 8vo. 15s. net. Origines Kalendariae Italicae. 4 vols. 8vo, £2 2s. net. Origines Kalendariae Hellenicae. 6 vols. 8vo. $£ 44$ s. net.

A Manual of Greek Historical Inscriptions. By E. L. Hrcks. New edition, revised by G. F. Hilc. 8vo. 10s. 6d. net.

Latin Historical Inscriptions, illustrating the history of the Early Empire. By G. MN. Rushrorth. 8vo. 10s. net.

Sources for Greek History between the Persian and Peloponnesian Wars. By G. F. Hiul. 8vo. Reissue, revised. 10s. 6d. net.

Sources for Roman History, в.c. 133-70. By A. H. J. GreENTDGE and A. M. Cray. Crown 8vo. 5s. 6d. net.

A Manual of Ancient History. By G. Rawrinson. 2nd ed. 8vo. 14s. Finlay's History of Greece from its Conquest by the Romans (B.c. 14.6) to A.D. 1864. A new edition, revised, and in part re-written, with many additions, by the Author, and edited by H. F. TozER. 7 vols. 8 vo. 63 ss. net. The History of Sicily from the earliest times. By E. A. FreEsar. 8vo.

Vols. I and II. The Native Nations: The Phoenician and Greek Settlements to the beginning of Athenian Intervention. £2 $2 \mathrm{~s}$. net.

Vol. III. The Athenian and Carthaginian Invasions. £1 4s. net.

Vol. IV. From the Tyranny of Dionysios to the Death of Agathoklês. Edited from posthumous MSS, by A. J. Evans. £1 1s. net.

Italy and her Invaders (A.D. 376-814). With plates and maps. Eight volumes. 8vo. By T. Hodgknv. Vols. I-IV in the second edition.

I-II. The Visigothic, Hunnish, and Vandal Invasions, and the Herulian Mutiny. £2 2s.

III-IV. The Ostrogothic Invasion. The Imperial Restoration. £1 16s. V-VI. The Lombard Invasion, and the Lombard Kingdom. £1 16s.

VII-VIII. Frankish Invasions, and the Frankish Empire. $£ 14 \mathrm{~s}$.

'The Dynasty of 'Theodosius ; or, Seventy Years' Struggle with the Barbarians. By the same author. Crown 8vo. 6s.

Aetolia ; its Geography, Topography, and Antiquities.

By W. J. WoopHouse. With maps and illustrations. Royal $8 v 0$. $£ 1$ ls, net. The Islands of the Aegean. By H. F. Tozвr. Crown 8vo. 8s. 6d. Dalmatia, the Quarnero, and Istria ; with Cettigne and Grado. By T.G.JAcrsov. Three volumes. With plates andillustrations. 8vo. 31s.6d. net.

Cramer's Description of Asia Minor. Two volumes. 8vo. 11s. Description of Ancient Greece. 3 vols. 8vo. 16s. 6d. 
The Cities and Bishoprics of Phrygia. By W. M. Rassay. Royal 8vo. Vol. I, Part I. The Lycos Valley and South-Western Phrygia. 18s. net. Vol. I, Par. II. West and West Central Phrygia. £1 Is. net.

Stories of the High Priests of Memphis, the Sethon of Herodotus, and the Demotic Tales of Khamnas. By F. L.. Griffirm. With Portfolio containing seven facsimiles. Royal 8vo. $£ 27 \mathrm{~s}$. 6d. net.

The Arab Conquest of Egypt. By A. J. Butur. With maps and plans. 8vo. $16 \mathrm{~s}$. net.

Baghdad during the Abbasid Caliphate, from contemporary sources: By G. LE Straxge. With eight plans. 8vo. 16s. net.

\section{Archaeology}

Ancient Khotan. Detailed report of Archaeological explorations in Chinese Turkestan carried out and described under the orders of H.M. Indian Government by M. Aurel Strix. Vol. I. Text, with descriptive list of antiques, seventy-two illustrations in the text, and appendices. Vol. II. One hundred and nineteen collotype and other illustrations and a map. 2 vols. 4to. $£ 55$ s. net.

Catalogue of the Coins in the Indian Museum, Calcutta, including the Cabinet of the Asiatic Society of Bengal. (Published for the Trustees of the Indian Museum.) Royal 8vo, with numerous collotype plates. Vol. I, by V. A. Sмгтн, 30s. net; or Part I (Early Foreign Dynasties and Guptas), 15s, net, Part II (Ancient Coins of Indian Types), 6s. net, Part III (Persian, Mediaeval, South Indian, Miscellaneous), 10s. 6d. net. Vol. II, by H. N. Wrigr (the first section of Part II by Sir J. BournruroN), 30s. net (Sultáns of Delhí, Contemporary Dynasties in India). Vol. III, by H. N. Wrigut, 4.0s. net (Mughal Emperors).

Ancient Coptic Churches of Egypt. By A. J. Butrer. 2 vols. 8vo. 30s.

A Catalogue of the Cyprus Museum. By J. L. Mrres and Max Ohnefalsch-Richter. 8vo. With eight plates, 7s. 6d. net.

A Catalogue of the Sparta Museum. By M. N. Ton and A. J. B. W AcE. 8vo. 10s. 6d. net.

Catalogue of the Greek Vases in the Ashmolean Museum. By P. Gardner. Small folio, linen, with 26 plates. $£ 3$ ss. net. The Cults of the Greek States. By L. R. Farneu. 8vo. Vols. I and II, with 61 plates and over 100 illustrations. $f 1$ 12s. net : Vols. III and IV, with 86 plates. $£ 1$ 12s. net.

Classical Archaeology in Schools. By P. Gardener and J. L. Mrres. 8vo. Second edition. Paper covers, 1s. net.

Introduction to Greek Sculpture. By L. E. Urcort. Second edition. Crown 8vo. 4s. $6 \mathrm{~d}$.

Marmorà Oxoniensia, inscriptiones Graecae ad Chandleri exempla editac, cur. Gul. Roberts, 1791. Crown 8vo. 3s. $6 \mathrm{~d}$.

De Antiquis Marmoribus, Blasii Caryophili. 1828. 7s. 6d.

Fiagmenta Herculanensia. A Catalogue of the Oxford copies of the

Herculanean Rolls, with texts of several papyri. ByW.Scotr. Royal 8vo. $£ 1$ ls.

Thirty-six Engravings of Texts and Alphabets from the Herculanean

Fragments. Folio. Small paper, 10s. 6d., large paper, $£ 1$ Is.

Herculanensium Voluminum Partes II. 1821. 8vo. 10s. 


\section{English History : Sources}

Baedae Opera Historica, edited by C. Prusiser. Two volumes. Crown 8vo, leather back. $£ 1$ 1s. net.

Asser's Life of Alfred, with the Annals of St. Neot, edited by W. H. Stevenson. Crown 8vo. 12s. net.

The Alfred Jewel, an historical essay. With illustrations and a map, by J. Earle. Small 4to, buckram. 12s. 6d, net.

Two of the Saxon Chronicles Parallel; with supplementary extracts from the others. A Revised Text, edited, with introduction, notes, appendices, and glossary, by C. Plumsirer and J. Earie. Two volumes. Crown 8vo, leather back. Vol. I. Text, appendices, and glossary. 10s.6d. Vol. II. Introduction, notes, and index. 12s. 6d.

The Saxon Chronicles (787-1001 A. D.). Crown 8vo, stiff covers. 3s.

Handbook to the Land-Charters, and other Saxonic Documents, by J. Earle. Crown 8vo. 16s.

The Crawford Collection of early Charters and Documents, now in the Bodleian Library. Edited by A. S. Napier and W. H. Stevenson. Small 4to, cloth. 12s. net.

The Chronicle of John of Worcester, 1118-1140. Edited by J. R. H. Weaver. Crown 4to. 7s. 6d. net.

Dialogus de Scaccario. Edited by A. Hughes, C. G. Crusip, and C. Jousson, with introduction and notes. 8vo. 12s. 6d, net.

Passio et Miracula Beati Olaui. Edited from the Twelfth-century MS by F. Metcalfe. Small 4to. 6s.

The Song of Lewes. Edited from the MS, with introduction and notes, by C. L. Kingsford. Extra fcap 8vo. 5s.

Chronicon Galfridi le Baker de Swynebroke, edited by Sir E. Maunde Thosrpson, K.C.B. Small 4to, 18s.; cloth, gilt top, $£ 1$ 1s.

Chronicles of London. Edited, with introduction and notes, by C. L. Kingsford. 8vo. 10s. 6d. net.

Gascoigne's 'Theological Dictionary ('LiberVeritatum'): selected passages, illustrating the condition of Church and State, 1403-1458. Witl an introduction by J. E. THorold Rogers. Small 4.to. 10s. $6 \mathrm{~d}$.

Fortescue's Governance of England. A revised text, edited, with introduction, etc, by C. Plusiser. 8vo, leather back. 12s. 6d.

Stow's Survey of London. Edited by C. L. Kingsrord. 8vo, 2 vols., with a folding map of London in 1600 (by EyERY WALKER and H. W. CrIBB) and other illustrations. 30 s. net.

The Protests of the Lords, from 1624 to 1874 ; with introductions. By J. E. ThовоLd Rogers. In three volumes. 8vo. £2 $2 \mathrm{s.}$ 


\section{The Clarendon Press Series of Charters, Statutes, etc}

From the earliest times to 1307. By Bishop Sturвs.

Select Charters and other illustrations of English Constitutional History. Eighth edition. Crown 8vo. 8s.6d.

From 1558 to 1625 . By G. W. Prothero.

Select Statutes and other Constitutional Documents of the Reigns of Elizabeth and James I. Third edition. Crown 8vo. 10s. 6d.

From 1625 to 1660 . By S. R. Gardiner.

The Constitutional Documents of the Puritan Revolution. Third edition. Crown 8vo. 10s. $6 \mathrm{~d}$.

\section{Calendars, etc}

Calendar of Charters and Rolls preserved in the Bodleian Library. 8vo. $\& 111$ s. 6 d.

Calendar of the Clarendon State Papers preserved in the Bodleian Library. In three volumes. 1869-76.

Vol. I. From 1523 to January 1649. 8vo. 18s. Vol. II. From 1649 to 1654. 8vo. 16s. Vol. III. From 1655 to 1657 . 8vo. 14s.

Hakluyt's Principal Navigations, being narratives of the Voyages of the Elizabethan Seamen to America. Selection edited by E. J. PAYse. Crown 8vo, with portraits. Second edition. Two volumes. 5s. each.

Also abridged, in one volume, with additional notes, maps, \&c., by C. Raymond Beazley. Crown 8vo, with illustrations. 4s. 6d. Also, separately, The Voyages of Hawkins, Frobisher, and Drake; The Voyages of Drake and Gilbert, each 2s. 6d.

Aubrey's 'Brief Lives,' set down between the Years 1669 and 1696. Edited from the Author's MSS by A. Cr.ark. Two volumes. 8vo. £1 5 s.

Whitelock's Memorials of English Affairs from 1625 to 1660.4 vols. 8vo. $£ 110$ s.

Ludlow's Memoirs, 1625-1672. Edited, with Appendices of Letters and illustrative documents, by C. H. Fritr. Two volumes. 8vo. $£ 116 \mathrm{~s}$.

Luttrell's Diary. A brief Historical Relation of State Affairs, 1678-1714. Six volumes. 8vo. £1 10s, net.

Burnet's History of James II. 8vo. 9s. 6d.

Life of Sir M. Hale, with Fell's Life of Dr. Hammond. Small 8vo. 2s. 6d.

Memoirs of James and William, Dukes of Hamilton. 8vo. 7s. 6d. 
Burnet's History of My Own Time. A new edition based on that of M. J. Rourr. Edited by Ossunve Arry. Vol. I. 12s. 6d. net. Vol. II. (Completing Charles the Second, with Index to Vols. I and II.) 12s. 6 d. net.

Supplement, derived from Burnet's Memoirs, Autobiography, etc, all hitherto unpublished. Edited by H. C. Foxcrort, 1902. 8vo. 16s. net.

The Whitefoord Papers, 1739 to 1810. Ed. by W. A. S. Hewrs. 8vo. 12s. $6 \mathrm{~d}$.

\section{History of Oxford}

A complete list of the Publications of the Oxford Historical Society can be obtained from Mr. Frowde.

Manuscript Materials relating to the History of Oxford ; contained in the printed catalogues of the Bodleian and College Libraries. By F. MADAN. 8vo. 7s. 6d.

The Early Oxford Press. A Bibliography of Printing and Publishing at Oxford, ' 1468 ' -1640 . With notes, appendices, and illustrations. By F. MADAN. 8vo. $18 \mathrm{~s}$.

\section{Bibliography}

Cotton's 'Typographical Gazetteer. First Series. 8vo. 12s. 6a, Ebert's Bibliographical Dictionary. 4 vols. 8 vo. $£ 33 s$. net.

\section{Bishop Stubbs's and Professor Freeman's Books}

The Constitutional History of England, in its Origin and Development. By W. Sturss. Library edition. Three volumes. Demy 8vo. 228 s. Also in three volumes, crown $8 \mathrm{vo}$, price $12 \mathrm{~s}$. each.

Seventeen Lectures on the Study of Mediaeval and Modern History and kindred subjects, 1867-1884. By the same. Third edition, revised and enlarged, 1900. Crown 8vo, half-roan. 8s. 6d.

History of the Norman Conquest of England; its Causes and Results. By E. A. FreEsaA. Vols. I, II and V (English edition) are out of print.

Vols. III and IV. £1 1s. each. Vol. VI (Index). 10s, $6 \mathrm{~d}$.

A Short History of the Norman Conquest of England. Third edition. By the same. Extra fcap 8vo. 2s. 6d.

The Reign of William Rufus and the Accession of Henry the First. By the same. Two volumes. 8vo. $£ 116 s$. 


\section{Special Periods and Biographies}

Ancient Britain and the Invasions of Julius Caesar. By T. Rice Holmes. 8vo. 21s. net.

Life and Times of Alfred the Great, being the Ford Lectures for 1901. By C. Plumsrer. 8vo. 5s. net.

The Domesday Boroughs. By Adolphus Ballard。 8vo. 6s. 6d. net.

Villainage in England. Essays in English Mediaeval History. By P. VinogradofF. 8vo. 16s, net.

English Society in the Eleventh Century. Essays in English Mediaeval History. By P. Vinogradoff. 8vo. 16s. net.

The Gild Merchant : a contribution to British municipal history. By C. Gross. Two volumes. 8 vo, leather back, $214 \mathrm{~s}$.

The Welsh Wars of Edward I; a contribution to mediaeval military history. By J. E. Morris. 8vo. 9s. 6d. net.

The Great Revolt of 1381. By C. Orras. With two maps. 8 ro. 8s. 6 d. net.

Lancaster and York. (A. D. 1399-1485.) By Sir J. H. Rassay. Two volumes. 8vo, with Index, £1 17s.6d. Index separately, 1s. 6d.

Life and Letters of Thomas Cromwell. By R. B. Merrisan. In two volumes. [Vol. I, Life and Letters, 1523-1535, etc. Vol. II, Letters, 1536-1540, notes, index, etc.] 8vo. 18s. net.

Edward Hyde, Earl of Clarendon. A lecture by C. H. Firth. 8ro. 1s. net.

A History of England, principally in the Seventeenth Century. By L. von RaNkE. Translated under the superintendence of G. W. KrтchiN and C. W. Bonse. Six volumes. 8vo. £3 3s. net. Index separately, Is.

Sir Walter Ralegh, a Biography, by W. Stebrrsc. Post 8vo. 6s. net.

Henry Birkhead and the foundation of the Oxford Chair of Poetry. By J. W. Mackail. 8vo. 1s. net.

Biographical Memoir of Dr. William Markham, Archbishop of York, by Sir Clesients Markhas, K.C.B. 8vo. 5s. net.

'The Life and Works of John Arbuthnot. By G. A. ArtкEv, 8vo, cloth extra, with Portrait. 16s. 
Life and Letters of Sir Henry Wotton.

Sirtr. 8vo. Two volumes. 25s. net.

Great Britain and Hanover. By A. W. WARD. Crown 8vo. 5s.

History of the Peninsular War. By C. Ossav. To be completed in six volumes, 8vo, with many maps, plans, and portraits.

Already published: Vol. I. 1807-1809, to Corunna. Vol. II. 1809, to Talavera. Vol. III. 1809-10, to Torres Vedras. 14s. net each.

Anglo-Chinese Commerce and Diplomacy : mainly in the nineteenth century. By A. J. Sargent. 12s. 6d. net.

Frederick York Powell. A Life and a selection from his Letters and Occasional Writings. By Ot,Iver Elros. Two volumes. 8vo. With photogravure portraits, facsimiles, etc. 21 s. net.

David Binning Monro: a Short Memoir. By J. Cook WiLsov. 8vo, stiff boards, with portrait. 2s. net.

F. W. Maitland. Two lectures by A. L. Sssrrs. 8vo. 2s. 6d, net.

\section{School Books}

Companion to English History (Middle Ages). Edited by F. P. Barnard. With 97 illustrations. Crown 8vo. 8s. 6d. net.

School History of England to the death of Victoria. With maps, plans, etc. By O. M. EDwards, R. S. Ratr, and others. Crown 8vo, 3s. 6d.

\section{Oxford School Histories}

Crown 8vo, with many illustrations, each $1 \mathrm{~s} .6 \mathrm{~d}$. net.

Berkshire, by E. A. G. LasBors.

Oxfordshire, by H. A. LidDeLL.

Others in preparation.

Also, for junior pupils, illustrated, each Is.

Stories from the History of Berkshire. By E. A. G. LasBons.

Stories from the History of Oxfordshire. By John Irvтsc. 


\section{History and Geography of America and the British Colonies}

For other Geographical books, see pages 59, 60 .

History of the New World called America. By E. J. Payne. Vol. I. 8vo. 18s. Bk. I. The Discovery. Bk. II, Part I. Aboriginal America. Vol. II. 8vo. 14s. Bk. II, Part II. Aboriginal America (concluded).

A History of Canada, 1763-1812. By Sir C. P. Lucas, K.C.M.G. 8 vo. With eight maps. 12s. 6 d. net.

The Canadian War of 1812. By Sir C. P. Lucas, K.C.M.G. 8 vo. With eight maps. 12s. 6d. net.

Historical Geography of the British Colonies. By Sir C. P. Lucas, K.C.M.G. Crown 8 vo.

Introduction. New edition by H. E. Egerton. 1903. (Origin and growth of the Colonies.) With eight maps. 3s. 6d. In cheaper binding, 2 s. $6 \mathrm{~d}$.

Vol. I. The Mediterranean and Eastern Colonies. With 13 maps. Second edition, revised and brought up to date, by R. E. STUBBs. 1906. 5s. .

Vol. II. The West Indian Colonies. With twelve maps. Second edition, revised and brought up to date, by C. Атснцет, I.S.O. 1905. 7s. 6d.

Vol. III. West Africa. Second Edition. Revised to the end of 1899 by H. E. Egerron. With five maps. 7s. 6 d.

Vol. IV. South and East Africa. Historical and Geographical. With eleven maps. 9s. 6d.

Also Part I. Historical. 1898. 6s. 6d. Part II. 1903. Geographical. 3s. 6 d.

Vol. V. Canada, Part I. 1901. 6s. Part II, by H. E. Egerton. 4s. 6d. Part III (Geographical) in preparation.

Vol. VI. Australasia. By J. D. Rogers. 1907. With 22 maps. 7s. 6d. Also Part I, Historical, 4s. 6d. Part II, Geographical, 3s. 6d. History of the Dominion of Canada. By W. P. Greswell. Crown 8vo. 7s. 6d. Geography of the Dominion of Canada and Newfoundland. By the same author. With ten maps. 1891. Crown 8vo. 6s.

Geography of Africa South of the Zambesi. By the same author. With maps. 1892. Crown 8vo. 7s. 6d.

The Claims of the Study of Colonial History upon the attention of the University of Oxford. An inaugural lecture delivered on April 28, 1906, by H. E. Eg ERToN. 8vo, paper covers, 1s. net.

Historical Atlas. Europe and her Colonies, 27 maps. 35s. net.

Cornewall-Lewis's Essay on the Government of Dependencies. Edited by Sir C. P. Lucas, K.C.M.G. 8vo, quarter-bound, 14s. 


\section{Rulers of India}

Edited by Sir W.W.Hunter. Crown 8vo. 2s. 6d. each. Asoka. Вy V. A. Sигтн. Bábar. By S. Lane-Poole. Albuquerque. By H. Morse Stephens. Akbar. By Colonel Malueson. Aurangzíb. By S. Lane-Poole. Dupleix. By Colonel Malleson. Lord Clive. By Colonel Malleson. Warren Hastings. By Captain L. J. Trotrer. Mádhava Ráo Sindhia. By H. G. Keene. The Marquis of Cornwallis. By W. S. Setox-Karr. Haidar Alí and Tipú Sultán. By L. B. Bowring. The Marquis Wellesley, K.G. By W. H. Hurtoov. Marquess of Hastings. By Major Ross-or-Bradessburg. Mountstuart Elphinstone. By J. S. Coтros. Sir Thomas Munro. By J. Bradshaw. Earl Amherst. By AnNe T. Rrtchie and R. Evans. Lord William Bentinck. By D. C. Bour.ger. The Earl of Auckland. By Captain L. J. TвоттеR. Viscount Hardinge. By his son, Viscount HardisGe. Ranjit Singh. By Sir L. Grifrix. The Marquess of Dalhousie. By Sir W. W. Huxter. James Thomason. By Sir R. Tessple. John Russell Colvin. By Sir A. Corvis. Sir Henry Lawrence. By Lieut.-General J. J. M'Leod Iswes. Clyde and Strathnairn. By Major-General Sir O. T. BurNE. Earl Canning. By Sir H. S. Cunxinghas.

Lord Lawrence. By Sir C. Arrchisov.

The Earl of Mayo. By Sir W. W. Hustre.

Sketches of Rulers of India. Abridged from the Rulers of India by G. D. Oswen.. Vol. I, The Mutiny and After; Vol. II, The Company's Governors ; Vol. III, The Governors-General ; Vol. IV, The Princes of India. Crown 8vo. 2s. net each. 
The Imperial Gazetteer of India. New edition. To be completed in twenty-six volumes. 8vo. Subscription price, cloth, £5 net; morocco back, $\pm 66 \mathrm{~s}$. net. The four volumes of "The Indian Empire" separately $6 \mathrm{~s}$. net each, in cloth, or 7s. 6d. net with morocco back; the Atlas separately $15 \mathrm{~s}$, net in cloth, or $17 \mathrm{~s}$. $6 \mathrm{~d}$. net with morocco back. Subscriptions may be sent through any bookseller.

Vol. I. Descriptive.

Vol. II. Historical.

Vol. III. Economic.

Vol. IV. Administrative.

Vol. V-XXIV. Alphabetical Gazetteer.

Vol. XXV. Index.

Vol. XXVI. Atlas.

Each volume contains a map of India specially prepared for this Edition.

\section{Reprints from the Imperial Gazetteer.}

A sketch of the Flora of British India. By Sir Josepr Hоoкer, 8vo. Paper covers. 1s. net.

The Indian Army. A sketch of its History and Organization. 8vo. Paper covers. 1s. net.

A Brief History of the Indian Peoples. By Sir W. W. Hunter. Revised up to 1903 by W. H. Hutron. Eighty-ninth thousand. 3s.6d.

The Government of India, being a digest of the Statute Law relating thereto; with historical introduction and illustrative documents. By Sir C. P. Ilbert. Second edition, 1907. 10s. 6d. net.

The Early History of India from 600 B.c. to the $\mathrm{Mu}$ hammadan Conquest, including the invasion of Alexander the Great. By V. A. Sirтt. 8vo. With maps, plans, and other illustrations. Second edition, revised and enlarged. 14s. net.

'The Oxford Student's History of India. By v. A. Ssrrrz. Crown 8vo. With 7 maps and 10 other illustrations. 2s. $6 \mathrm{~d}$.

The English Factories in India : By W. Foster. 8vo. (Published under the patronage of His Majesty's Secretary of State for India in Council.)

Vol. I. 1618-1621. 12s. 6d. n. Vol. II. 1622-1623. 12s. 6d. n.

(The six previous volumes of Letters received by the East India Company from its Servants in the East (1602-1617) may also be obtained, price 15s. each volume.)

Court Minutes of the East India Company, 1635-1639. By E. B. Sarnsbury. Introduction by W. Foster. 8vo. 12s. 6d. net.

The Court Minutes of the Company previous to 1635 have been calendared in the Calendars of State Papers, East Indies, published by the Public Record Office.

Wellesley's Despatches, Treaties, and other Papers relating to his Government of India. Selection edited by S. J. OwEN. 8vo. £1 4s.

Wellington's Despatches, Treaties, and other Papers relating to India. Selection edited by S. J. OwEv. 8vo. £1 4s.

Hastings and the Rohilla War. By Sir J. Stracher. 8vo. 10s. 6d. 


\section{European History}

Historical Atlas of Modern Europe, from the Decline of the Roman Empire. 90 maps, with letterpress to each : the maps printed by W. \& A. K. Johnston, Ltd., and the whole edited by R. L. PoozE.

In one volume, imperial 4to, half-persian, $£ 515 \mathrm{~s}$. $6 \mathrm{~d}$. net; or in selected sets-British Empire, etc, at various prices from 30s. to $35 \mathrm{~s}$. net each : or in single maps, 1s. 6 d. net each. Prospectus on application.

Genealogical Tables illustrative of Modern History. By H. B. GrorGE. Fourth (1904) edition. Oblong 4to, boards. 7s. 6d.

The Life and Times of James the First of Aragon. By F. D. SwrFr. 8vo. 12s. 6d.

The Renaissance and the Reformation. A textbook of European History, 1494-1610. By E. M. TANNER. Crown 8vo, with 8 maps. 3s. 6d.

A History of France, with numerous maps, plans, and tables, by G. W. Krtchin. Crown 8vo ; Vol. I (to 1453), revised by F. F. Urquhart; Vols. II (1624), III (1795), revised by A. HassaL... 10s. 6d. each volume.

De Tocqueville's L'Ancien Régime et la Révolution. Edited, with introductions and notes, by G. W. Headrass. Crown 8vo. 6s.

The Principal Speeches of the Statesmen and Orators of the French Revolution, 1789-1795: Ed. H. Morse Stephess. Two vols. Crown 8vo. \&1 1s.

Documents of the French Revolution, 1789-1791. By L. G. Wickham Legg. Crown 8vo. Two volumes. 12s. net.

Napoleonic Statesmanship: Germany. By H. A. L. Frsher. 8vo, with maps. 12s. 6d. net.

Bonapartism. Six lectures by H. A. L. Fisher. 8vo. 3s. 6d. net. 'Thier's' Moscow Expedition, edited by H. B. Grorge. Cr. 8vo, 6 maps. 5s.

Great Britain and Hanover. By A. W. Ward. Crown 8vo. 5s. History of the Peninsular War. By C. Osras. To be completed in six volumes, 8vo, with many maps, plans, and portraits.

Already published : Vol. I. 1807-1809, to Corunna. Vol. II. 1809, to Talavera. Vol. 111. 1809-10, to Torres Vedras. 14s. net each.

\section{The Oxford Geographies}

Relations of Geography and History. By H. B. George. With two maps. Crown 8vo. Third edition. 4s. $6 d$.

Geography for Schools, by A. Hugres. Crown 8vo. 2s. 6d.

The Oxford Geographies. By A. J. Herbertson. Crown $8 v 0$.

Vol. 1. The Preliminary Geography, Ed. 2, 72 maps and diagrams, 1s. 6d.

Vol. II. The Junior Geography, Ed. 2, 166 maps and diagrams, 2s.

Vol. 1il. The Senior Geography, Ed.2, 117 maps and diagrams, 2s. 6d.

Practical Geography. By J. F. Unstead. Crown 8vo. Part I, 27 maps and diagrams, Part II, 21 maps and diagrams, each 1s, 6d., together 2s. 6d. 


\section{Geography and Anthropology}

The Dawn of Modern Geography. By C. R. BeAzLey. In three volumes. £2 10s. Vol. 1 (to A.D. 900). Not sold separately. Vol. II (A.D. 900-1260). 15s. net. Vol. III. 20s. net.

Regions of the World. Geographical Memoirs under the general editorship of H. J. Mackinder. Medium 8vo. 7s. 6d. net per volume.

Britain and the British Seas. Second edition. By H. J. Mackinder. Central Europe. By John Partsch. - The Nearer East. By D. G. Hogarth. - North America. By J. Russell. - India. By Sir Thosias Holdich. - The Far East. By Archibald Littre.

Frontiers : Romanes Lecture for 1907. By Lord Cunzon of Kedieston. 8vo. 2s. net.

The Face of the Earth. By Eduand Surss. See p. 92.

Transactions of the Third (1908) International Congress for the History of Religions. Royal 8vo. 2 vols. 21s. net.

Anthropological Essays presented to Enward Burnett Trlor in honour of his seventy-fifth birthday; by H. Balfour, A. E. Crawley, D. J. Cuxninghas, L. R. Farvele, J. G. Frazer, A. C. Haddon, E. S. Hartuand, A. Lang, R. R. Marett, C. S. Myers, J. L. Myres, C. H. Read, Sir J. RhŶs, W. Ridgeway, W. H. R. Rivers, C. G. Seligarany, T. A. Joyce, N. W. Thomas, A. Thosson, E. Westersarck; with a bibliography by Barbara W. Freire-Marneco. Imperial 8vo. 21s. net.

The Evolution of Culture, and other Essays, by the late Lieut.-Gen. A. Lane-Fox PrTT-RIvers; edited by J. L. MYres, with an Introduction by $\mathrm{H}$. BaLFour. 8 vo, with 21 plates, $7 \mathrm{~s}$. $6 \mathrm{~d}$. net.

Anthropology and the Classics. Six lectures by A. Evavs, A. Layg, G. G. A. Murray, F. B. Jevons, J. L. Myres, W. W. Fowler. Edited by R. R. MARETT. 8vo. Illustrated. 6s. net.

Folk-Memory. By Watter Johssov. 8vo. Illustrated. 12s. 6d. net. Celtic Folklore: Welsh and Manx. By J. RHŶ̀s. 2 vols. 8vo. $£ 1$ Is. Studies in the Arthurian Legend. By J. RHŶs. 8vo. 12s. 6d. Iceland and the Faroes. By N. Ansandale. With an appendix on the Celtic Pony, by F. H. A. Marshall. Crown 8vo. 4s. 6d. net.

Dubois' Hindu Manners. Translated and edited by H. K. BEaUchamp. Third edition. Crown 8vo. 6s. net. On India Paper, 7s. 6d. net. The Melanesians, studies in their Anthropology and Folk-Lore. By R. H. Conrington. 8vo. 16s. net.

The Masai, their Language and Folk-lore. By A. C. Houss. With introduction by Sir Charles Eusot. 8vo. Illustrated. 14s. net. The Nandi, their Language and Folk-lore. By A. C. Howrs. With introduction by Sir CiranLes Eu.jot. 8vo. Illustrated. 16s. net. The Ancient Races of the Thebaid : an anthropometrical study. By Arthur Thosison and D. RANDali-MacIver. Imperial 4to, with 6 collotypes, 6 lithographic charts, and many other illustrations. 42s. net.

The Earliest Inhabitants of Abydos. (A craniological study.)

By D. Randalz-MacIver. Portfolio. 10s. 6d. net. 


\section{LAW}

\section{Jurisprudence}

Bentham's Fragment on Government. Edited by F. C. Montague. 8vo. 7s. $6 \mathrm{~d}$.

Bentham's Introduction to the Principles of Morals and Legislation. Second edition. Crown 8vo. 6s. 6d.

Studies in History and Jurisprudence. By the Right Hon. JAMES BRyce. 1901. Two volumes. 8vo. £l 5s. net.

The Elements of Jurisprudence. By T. E. Horrand. Tenth edition. 1906. 8vo. 10s. $6 \mathrm{~d}$.

Elements of Law, considered with reference to Principles of General Jurisprudence. By Sir W. MarkBY, K.C.I.E. Sixth edition revised, 1905. 8vo. 12s, $6 \mathrm{~d}$.

\section{Roman Law}

Imperatoris Iustiniani Institutionum Libri Quattuor; with introductions, commentary, and translation, by J. B. MoxLE. Two volumes. 8vo. Vol. I (fourtl edition, 1903), 16s.; Vol. II, Translation (fourth edition, 1906), 6s.

The Institutes of Justinian, edited as a recension of the Institutes of Gaius. By T. E. Holland. Second edition. Extra fcap 8vo. 5s.

Select Titles from the Digest of Justinian. By T. E. Hourasd and C. L. Shadwel. 8vo. 14s.

Also, sold in parts, in paper covers : Part I. Introductory Titles. 2s. 6d. Part II. Family Law. 1s. Part III. Property Law. 2s. 6d. Part IV. Law of Obligations. No. 1. 3s, 6d. No. 2. 4s. $6 \mathrm{~d}$.

Gai Institutionum Iuris Civilis Commentarii Quattuor : with a translation and commentary by the late E. Poste. Fourth edition. Revised and enlarged by E. A. Whтттск, with an historical introduction by A. H. J. Greenidge. 8vo. 16s. net.

Institutes of Roman I,aw, by R. Soнs. Translated by J. C. Ledue: with an introductory essay by E. Gruerer. Third edition. 8vo. 16s. net.

Infamia; its place in Roman Public and Private Law. By A. H. J. GrEeNidGE. 8vo. 10s. $6 \mathrm{~d}$.

Legal Procedure in Cicero's Time. By A. H. J. Greenwog. 8 vo. $25 \mathrm{~s}$, net.

The Roman Law of Damage to Property: being a commentary on the title of the Digest 'Ad Legem Aquiliam' (ix. 2), with an introduction to the study of the Corpus I uris Civilis. By E. Gruerer. 8vo. 10s.6d.

Contract of Sale in the Civil Law. By J. B. Morue. 8vo. 10s.6d.

The Principles of German Civil Law. By Ernest J. Schuster. 8vo. 12s. 6d. net. 


\section{English Law}

Principles of the English Law of Contract, and of Agency in its relation to Contract. By Sir W. R. Assov. Eleventh edition. 1906. 8vo. 10s. 6d.

Law and Custom of the Constitution. By the same. In two volumes. 8vo.

Vol. I. Parliament. (Out of print. New edition in the press.)

Vol. II. The Crown. Third edition. Part I, 10s. 6d. net. Part II, 8s. 6 d. net.

Introduction to the History of the Law of Real Property. By Sir K. E. Digry. Fifth edition. 8vo. 12s. 6d.

Legislative Methods and Forms. By Sir C. P. ILBERT, K.C.S.I. 1901. $8 \mathrm{vo}$, leather back, $16 \mathrm{~s}$.

Modern Land Law. By E. Jenks. 8vo. 15s.

Essay on Possession in the Common Law. By Sir F. Pollock and Sir R. S. Wright. 8vo. 8s. 6d.

Outline of the Law of Property. By T. RaLitgr. 8vo. 7s. 6d. Law in Daily Life. By Rud. von Jhering. Translated with Notes and Additions by H. Goudy. Crown 8vo. - 3s. 6d. net.

Cases illustrating the Principles of the Law of 'Torts, with table of all Cases cited. By F. R. Y. Radchifre and J. C. Mir.es. 8 vo. 1904. 12s. 6d. net.

The Management of Private Affairs. By Joseri King, F. T. R. Bighas, M. L. Gwyer, Edwin Cannan, J. S. C. Bridge, A. M. Latrer. Crown 8vo. 2s. 6d. net.

Calendar of Charters and Rolls, containing those preserved in the Bodleian Library. Svo. $£ 111$ s. 6 d.

Handbook to the Land-Charters, and other Saxonic Documents. By J. Earle. Crown 8vo. 16s.

Fortescue's Difference between an Absolute and a Limited Monarchy. Text revised and edited, with introduction, etc, by $\mathrm{C}$. Prumsrer. 8vo, leather back, 12s. 6d.

Villainage in England. By P. Vinogradofr. 8vo. 16s. net.

Welsh Mediaeval Law: the Laws of Howel the Good. Text, translation, etc., by A. W. WADE Evass. Crown 8vo. 8s. 6d. net.

\section{Constitutional Documents}

Select Charters and other Illustrations of English Constitutional History, from the earliest times to Edward I. Arranged and edited by W. STUввs. Eighth edition. 1900. Crown 8vo. 8s. 6d.

Select Statutes and other Constitutional Documents, illustrative of the reigns of Elizabeth and James I. Edited by G. W. Prothero. Third edition. Crown 8 vo. 10s. $6 \mathrm{~d}$.

Constitutional Documents of the Puritan Revolution, selected and edited by S. R. Gardiner. Third edition. Crown 8vo. 10s.6d. 


\section{International Law}

International Law. By W. E. HAI工。 Fifth edition by J. B. AтLux. 1904. 8vo. $\& 1$ ls. net.

Treatise on the Foreign Powers and Jurisdiction of the British Crown. By W. E. HaLL. 8vo. 10s. 6d.

The European Concert in the Eastern Question, a collection of treaties and other public acts. Edited, with introductions and notes, by T. E. Holuand. 8vo. 12s, 6d.

Studies in International Law. By T. E. Hourasd. 8vo. 10s. 6d. The Laws of War on Land. By T. E. Horland. 8vo. 6s. net. Gentilis Alberici de Iure Belli Libri Tres edidit T. E. HoLluNd. Small quarto, half-morocco. £1 1s.

The Law of Nations. By Sir T. Twiss. Part I. In time of peace. New edition, revised and enlarged. 8vo. 15s.

Pacific Blockade. By A. E. Hogav. 8vo. 6s, net.

\section{Colonial and Indian Law}

The Government of India, being a Digest of the Statute Law relating thereto, with historical introduction and illustrative documents. By Sir C. P. ILBERT, K.C.S.I. Second edition. 8vo, cloth. 10s. 6d. net.

British Rule and Jurisdiction beyond the Seas. By the late Sir H. JenkYns, K.C.B., with a preface by Sir C. P. Il.BeRT, and a portrait of the author. 1902. 8vo, leather back, 15s. net.

Cornewall-Lewis's Essay on the Government of Dependencies. Edited by Sir C. P. Lucss, K.C.M.G. 8vo, leather back, 14s.

An Introduction to Hindu and Mahommedan Law for the use of students. 1906. By Sir W. MarkBY, K.C.I.E. 6s. net.

Land-Revenue and Tenure in British India. By B. H. BaDEN-Powel, C.I.E. With map. Second edition, revised by T. W. Holderness, C.S.I. (1907.) Crown 8vo. 5s. net.

Land-Systems of British India, being a manual of the LandTenures, and of the systems of Land-Revenue administration. By the same. Three volumes. 8vo, with map. $£ 33$ s.

Anglo-Indian Codes, by Whituey Stokns. - 8 vo.

Vol. I. Substantive Law. $£ 1$ 10s. Vol. II. Adjective Law. $£ 115 \mathrm{~s}$.

1st supplement, $2 \mathrm{~s}$. $6 \mathrm{~d}$. 2nd supplement, to 1891, 4s. $6 \mathrm{~d}$. In one vol., $6 \mathrm{~s}$. $6 \mathrm{~d}$.

The Indian Evidence Act, with notes by Sir W. Mankay, K.C.I.E. 8vo. 3s. 6 d. net (published by Mr. Frowde).

Corps de Droit Ottoman : un Recueil des Codes, Lois, Règlements, Ordonnances et Actes les plus importants du Droit Intérieur, et d'Études sur le Droit Coutumier de l'Empire Ottoman. Par Grorge Yousc. Seven vols. 8vo. Cloth, 24 14s. 6 d. net; ; paper covers, $£ 4$ 4s. net. Parts I (Vols. I-III) and II (Vols. IV-VII) can be obtained separately; price per part, in cloth, $£ 217$ s. 6 d. net. in paper covers. $£ 2$ 12s. 6 d. net. 


\section{Political Science and Economy}

For Bryce's Studies and other books on general jurisprudence and political science, see p. 61.

Industrial Organization in the 16th and 17th Centuries. By G. UNwis. 8vo. 7s. 6d. net.

Relations of the Advanced and Backward Races of Mankind, the Romanes Lecture for 1902. By J. BRYcE. 8vo. 2s. net. Cornewall-Lewis's Remarks on the Use and Abuse of some Political Terms. New edition, with introduction by T. Rateigh. Crown 8vo, paper, 3s. 6d. ; cloth, 4s. 6d.

Adam Smith's Wealth of Nations. Edited by J. E. Trorow Rog ERs. Two volumes. 8vo. £1 1s. net.

Adam Smith's Lectures on Justice, Police, Revenue and Arms. Edited with introduction and notes by E. CanNaN. 8vo. 10s. 6d. net.

Bluntschli's 'Theory of the State. Translated from the sixth German edition. Third edition. 1901. Crown 8vo, leather back, 8s. 6d. .

Co-operative Production. By B. Jones. With preface by A. H. DYKe-Acland. Two volumes. Crown 8vo. 15s. net.

A Geometrical Political Economy. Being an elementary Treatise on the method of explaining some Theories of Pure Economic Science by diagrams. By H. Cunynghame, C.B. Cr. 8vo. 2s. 6d. net. The Elements of Railway Economics. By W. M. Acwortr. Crown 8vo. Second impression. 2s. net.

Elementary Political Economy. By E. Cannan. Fourth edition. Extra fcap 8vo, 1s. net.

Elementary Politics. By Sir T. RaLeigr. Sixth edition revised. Extra fcap 8vo, stiff covers, 1s. net.

The Study of Economic History. By L. L. Price. 1s. net.

\section{Economic Documents}

Ricardo's Letters to Malthus (1810-1823). Edited by J. Bovar. 8vo. 7s. $6 \mathrm{~d}$.

Letters to 'Trower and others (1811-1823). Edited by J. Bonar and J. H. Holiander. 8vo. 7s. 6d.

Lloyd's Prices of Corn in Oxford, 1583-1830. 8vo. 1s. The History of Agriculture and Prices in England, A.D. 1259-1793. BY J. E. THоRоL. Rogers.

Vols. I and II (1259-1400). 8vo. 84s. net.

Vols. III and IV (1401-1582). 8vo. 32s. net.

Vols. V and VI (1583-1702). 8vo. 32s. net.

Vol. VII. In two Parts (1702-1793). 8vo. 32s. net.

First Nine Years of the Bank of England. By the same. 8vo. 8s. 6 d. 




\section{Date Due}

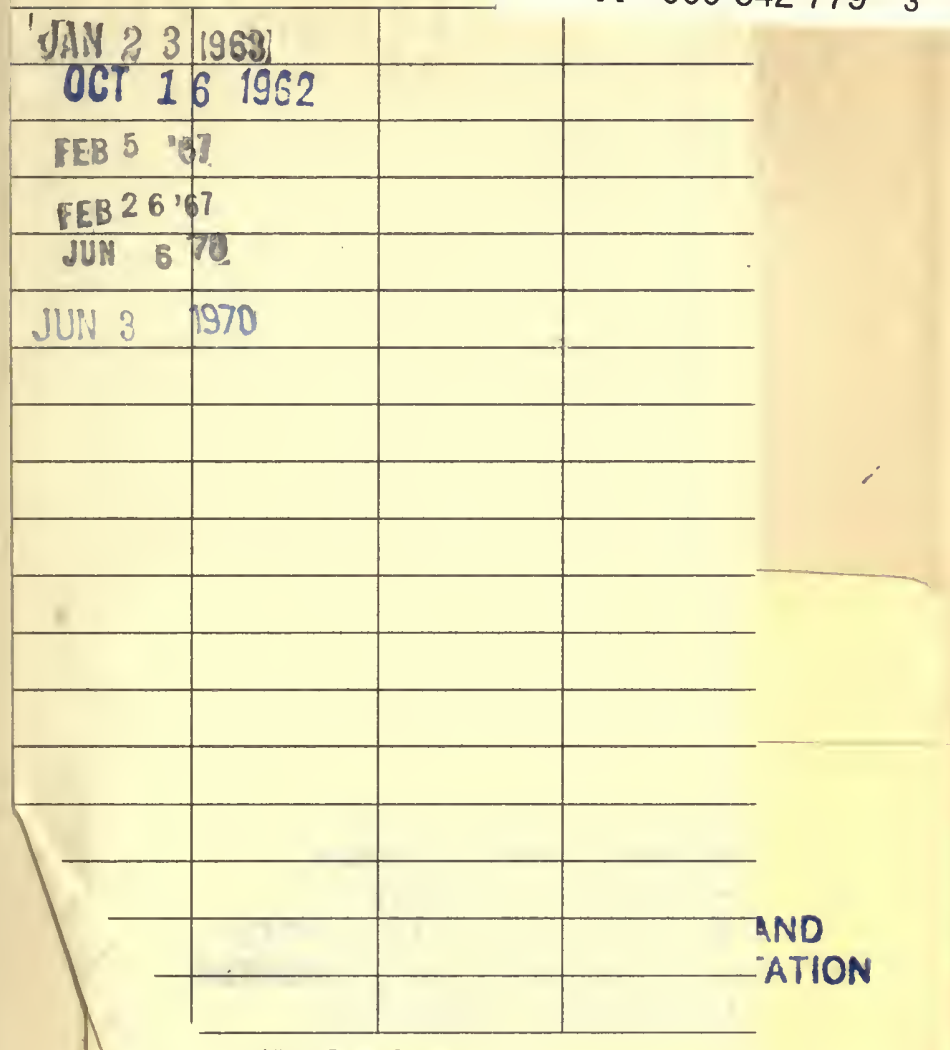

Library Bureau Cat. No. 1137 


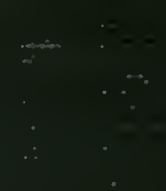

